Accounts of Damage from Historical Earthquakes in the Northeastern Caribbean, to Aid in the Determination of their Location and Intensity Magnitudes

Open-File Report 2011-1133 
This page has been left blank intentionally. 


\section{Accounts of Damage from Historical Earthquakes in the Northeastern Caribbean, to Aid in the Determination of their Location and Intensity Magnitudes}

By Claudia H. Flores, Uri S. ten Brink, and William H. Bakun

Open-File Report 2011-1133 


\section{U.S. Department of the Interior \\ KEN SALAZAR, Secretary}

\section{U.S. Geological Survey \\ Marcia K. McNutt, Director}

U.S. Geological Survey, Reston, Virginia 2012

For product and ordering information:

World Wide Web: http://www.usgs.gov/pubprod

Telephone: 1-888-ASK-USGS

For more information on the USGS-the Federal source for science about the Earth, its natural and living resources, natural hazards, and the environment:

World Wide Web: http://www.usgs.gov

Telephone: 1-888-ASK-USGS

Suggested citation:

Flores, C.F., ten Brink, U.S., and Bakun, W.H., 2012, Accounts of damage from historical earthquakes in the Northeastern Caribbean to aid in the determination of their location and intensity magnitudes: U.S. Geological Survey, Open-File Report 2011-1133, $237 p$.

Any use of trade, product, or firm names is for descriptive purposes only and does not imply endorsement by the U.S. Government.

Although this report is in the public domain, permission must be secured from the individual copyright owners to reproduce any copyrighted material contained within this report. 


\section{Acknowledgements}

The preparation of this catalog benefited much from the guidance of Colleen Hurter of the Marine Biological Laboratory/Woods Hole Oceanographic Institute data library archives. She pointed out the availability of many online databases and facilitated the various interlibrary requests made for information. 


\section{Contents}

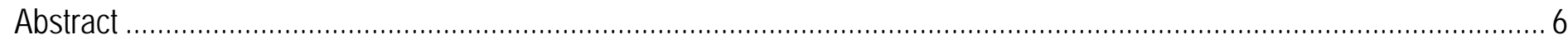

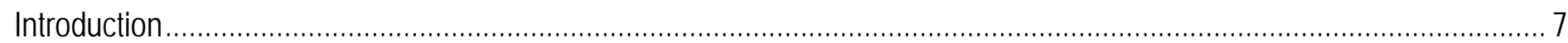

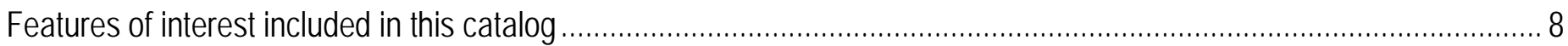

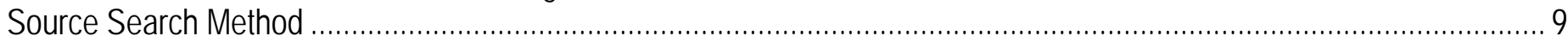

The Bulletins from the meteorological observatory in Port-au-Prince, Haiti ................................................................ 12

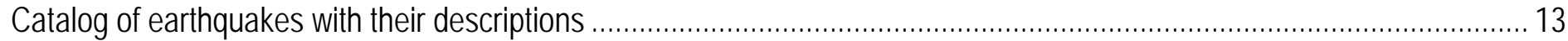

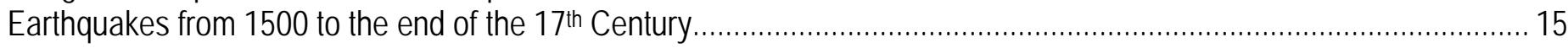

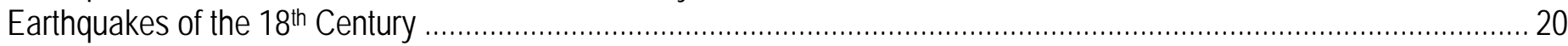

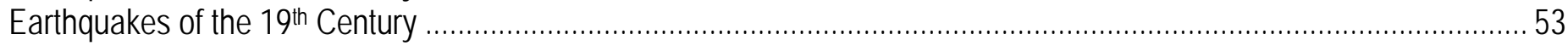

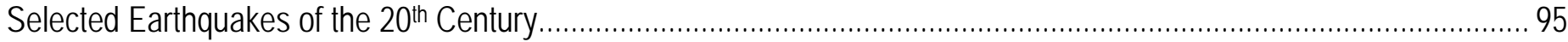

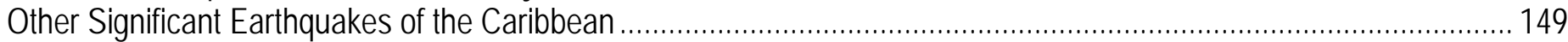

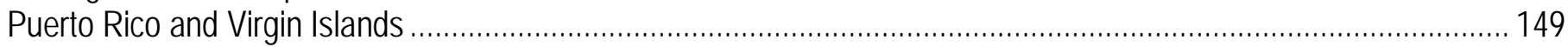

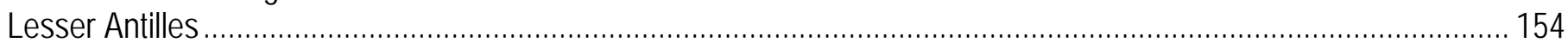

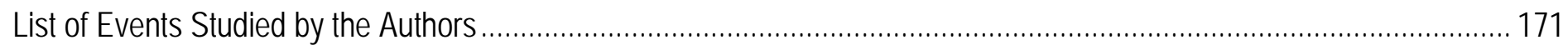

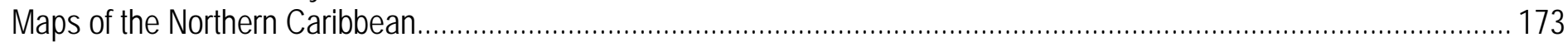

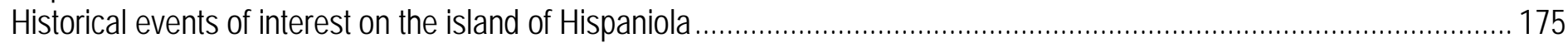

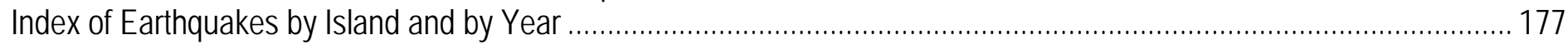

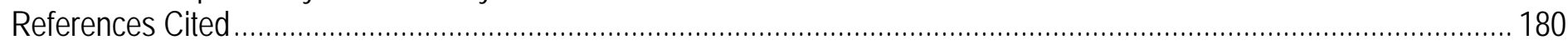

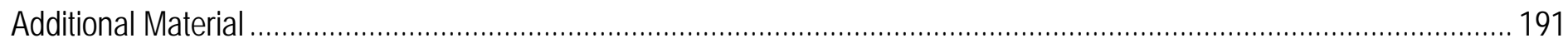

Quoted text extracted from de Utrera (1995, p. 17-18) explaining that the true date of the "1564" earthquake

is actually December 2, 1562, based on evidence from contemporary source .................................................... 191

Geographic locations used in the catalog for the Northern Caribbean ............................................................... 193

\section{Figures}

1. Tectonic Map of the Northern Caribbean showing the islands of Hispaniola, Puerto Rico, Virgin Islands, and Northern Lesser Antilles

2. Map of the island of Hispaniola showing the locations of cities and towns with significant populations.

\section{Tables}

1. Events studied further in Bakun and others (in press) and ten Brink and others (2011) ................................. 171

2. Earthquake Modified Mercalli Intensity Criteria.......................................................................................... 172

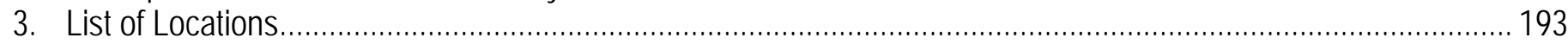




\title{
Accounts of Damage from Historical Earthquakes in the Northeastern Caribbean, to Aid in the Determination of their Location and Intensity Magnitudes
}

\author{
By Claudia H. Flores, Uri S. ten Brink, and William H. Bakun
}

\begin{abstract}
Earthquakes have been documented in the northeastern Caribbean since the arrival of Columbus to the Americas; written accounts of these felt earthquakes exist in various parts of the world. To better understand the earthquake cycle in the Caribbean, the records of earthquakes in earlier catalogs and historical documents from various archives, which are now available online, were critically examined. This report updates previous catalogs of earthquakes, in particular earthquakes in Hispaniola, to give to the public the most comprehensive documentation of earthquake damage and to further the understanding of the earthquake cycle in the northeastern Caribbean.

Documentation of an event in the past depended on the population and political trends of the island, and the availability of historical documents is limited by the physical resource digitization schedule and by the copyright laws of each archive. Examples of documents accessed are governors' letters, newspapers, and other circulars published within the Caribbean, North America, and Western Europe. Key words were used to search for publications that contain eyewitness accounts of various large earthquakes. Finally, this catalog provides descriptions of damage to buildings used in previous studies for the estimation of moment intensity (MI) and location of significantly damaging or felt earthquakes in Hispaniola and in the northeastern Caribbean, all of which have been described in other studies.
\end{abstract}

\section{Introduction}

The preparation of this catalog of reports of Caribbean earthquakes felt since 1492 was prompted by the January 12, 2010, $\mathrm{M}_{\mathrm{W}} 7.0$ earthquake that caused significant devastation and more than 222,000 deaths in the city of Port-au-Prince, Haiti, and its immediate surroundings. Parts of the extensive destruction can be attributed to the lack of earthquake awareness and preparedness (Eberhard and others, 2010). If the past is the key to the future, then the accounts of earthquake effects in the Caribbean over the past 5 centuries provide critical information for understanding the seismic hazard and the appropriate preparedness measures for Haiti and other countries throughout the Caribbean. This report constitutes a catalog of accounts of historical earthquakes since 1492 and modified Mercalli intensity assignments for significantly damaging or felt events that can be used to better characterize historical earthquakes, especially on the island of Hispaniola where Haiti and the Dominican Republic are located.

The goal for this catalog is to present as much information as possible on damages from past earthquakes for the purpose of determining earthquake intensities and to improve on past catalogs, 
especially for those earthquakes before the 20th century. In the past, comprehensive compilation of damage reports depended on physically accessing documents in libraries around the world. Because many libraries have made their collections available online, documents can now be compared side by side, independent of their originating archive. Moreover, many of these documents are searchable, allowing for rapid, efficient location of particularly relevant damage descriptions. The reader is encouraged to consult Bakun and others (2012) and ten Brink and others (2011) on the research resulting from the intensity assignments for selected earthquakes and their conclusions for the tectonics and earthquake cycle for the northeastern Caribbean. Bakun and others (2012) focus on the research surrounding the Enriquillo-Plantain Fault System in southern Hispaniola. Ten Brink and others (2011) provide a more general view of selected large magnitude earthquakes that have occurred in the northeastern Caribbean and their resulting seismic hazards for the region. The selection of earthquakes in this catalog was based on the scientific questions asked in these two studies. As a result, the focus of this catalog is primarily on earthquakes in Hispaniola, especially before the 20th century. This is why only a few earthquakes from other parts of the Caribbean are included in this catalog, and the 20th century list is not comprehensive.

Much of this work would not have been possible if it were not for the Internet Archives, Digital Library of the Caribbean (dLOC), the Hathi Trust Digital Library, the Google Books Library Project, Gallica-Bibliotheque National de France, the Biblioteca Nacional de España that hosts the Hermeroteca Digital, the Portal de Archivos Españoles (PARES) hosted by the Ministry of Culture of Spain, and other libraries that have made their databases available online. Some documents remain unavailable either because of copyright protection or because they have not yet been digitized. The list of available sources continues to grow; therefore, the reader is encouraged to search for new material as it becomes available online. For the preparation of this publication, many of these online archives were last accessed as of August 2011.

\section{Features of Interest Included in this Catalog}

Several items are included in this catalog, which provide context to the information presented or are possible sources of information for further research. A list is provided of significant historical events that most likely affected the reporting of earthquakes and that help to place damage reports in historical context. The list is not a comprehensive history of the island; therefore, the reader is directed to the other sources for a fuller discussion of history, such as del Monte y Tejada (1890), Heinl and Heinl (1978) and Figueredo and Argote-Freyre (2008). The population of the island of Hispaniola has not been evenly distributed or continuous since its discovery in 1492 nor has the territory been managed by only one country for its entire history. To understand why there are reports for some parts of the island but not for others, a glance at the edited list of significant events provides a quick explanation. A historical context for reports of damage or reports of feeling an earthquake provides an understanding of why some reports can be found in some archives but not in others.

The large number of events included in this catalog necessitates the inclusion of an index to ease the search for a particular event. Although the catalog is divided by century, the majority of events fall within the last three centuries, and tables of descriptions for the larger earthquakes span several pages. The index of earthquakes is organized by year and by island on page 177 .

As mentioned in the introduction, several events were studied further by the authors, with the objective of answering fundamental questions that resulted from the 2010 Haitian earthquake. A list of these earthquakes and where to find their descriptions in the catalogue is given in table 1 on page 171 . The research focused on only a few earthquakes; therefore, descriptions of those earthquakes and a few 
others with a significant number of damage reports are listed in table 1 and contain the authors' contribution, which is the assignment of a moment intensity value.

In addition, the bibliography contains links to reference materials that are currently in the public domain. Considering the large amount of material in the public domain that was accessed for this catalog, the authors decided that providing links to the original sources would be more helpful for future research than integrating the original material, especially the non-English sources, into the catalog. The links direct the reader either to the first page of the source material or to the main document. For sources consulted that contain multiple volumes, individual links have been provided for each volume. The New York Times provides only downloadable PDF copies of their issues, and the availability depends on the time period accessed. For the New York Times issues, a direct link to the archive pages is provided.

Finally, the appendix contains other materials that may be of interest to the reader. Quoted text from de Utrera (1995) concerning the 1562 earthquake and a listing of damage-site geographic coordinates used in this catalog are provided in table form.

\section{Source Search Method}

Jean Vogt contributed much to the methods of evaluating historical seismology by pointing out the pitfalls in many earthquake catalogs and by publishing case studies of individual earthquakes, which has been a benefit to researchers (Vogt, 1991 2009; Fréchet and others, 2008). For further guidance on the techniques and methods of historical seismology, the reader is directed to publications by Fréchet and others (2008) and Guidoboni and Ebel (2009). The most rudimentary process for doing historical seismology work includes searching for as many original accounts of an earthquake as possible, using the reference list in catalogs to help track down these original sources, and taking advantage of online search engines to find previously untapped sources of earthquake information.

For this catalog, the search began with original sources by first identifying modern earthquake catalogues of historical events and looking at their reference materials using the methods suggested by Vogt (2009). Older catalogues from previous centuries and their original source materials are identified if they were referenced. Once those original sources were identified, searches using established library tools were made to obtain copies of the original materials. Many historical documents are now available online or are easily found through online catalogues (see References Cited). The following sources were the most useful in obtaining the original source or documents with information relating to historical earthquakes: Moreau de St. Méry’s $(1796,1798)$ volumes on the history of Hispaniola, Poey’s (1857) catalogue of earthquakes from the Caribbean, Mallet and Mallet's (1858) worldwide catalogue of earthquakes, Perrey's yearly catalogues of earthquakes (1843-1873) and catalogue of Caribbean earthquakes, Tippenhauer's (1893) list of Hispaniola earthquakes, and the McCann and others (2011) on earthquakes felt in Puerto Rico.

Moreau de St. Méry - This author provides the most in depth information for earthquakes during the early to mid-18th century in Haiti and Dominican Republic (Moreau de St. Méry, 1796, 1798). The author lived on the island in the second half of the 18th century. The author self published his volumes on the history of Hispaniola, then known as Santo Domingo, first of the Spanish side in 1796 and then the French side in 1798. As a result, he provides the most information on the effects of the June 3 , 1770, earthquake outside of news magazines from France and Spain of that period. The volumes are organized by city or town with a history of their establishment and finally the typical weather, geographical characteristics, and the known earthquakes that were felt and had damage reports. Many modern catalogues and historians cite Moreau de St. Méry’s work. 
Poey - This author provides two sources (Poey, 1855, 1857), a catalog of known earthquakes to have occurred up until 1857 in the Caribbean and a history of hurricanes for the same period and region. Both catalogs describe the source material Poey used to compile these lists of earthquakes and hurricanes with no further information beyond the date and possible times of each event. These catalogs were useful because of the detailed references used to track down the original source materials for damage descriptions of the events, including histories, newspaper reports, scientific publications of the period, and personal letters published in history books. The only caveat for these catalogs is that Poey used what was available to him at the time, and most of the sources, especially closer to his time period, are French biased. Many modern catalogs for both earthquakes and hurricanes cite these catalogs as their main source. Poey originally lived on the island of Cuba and established a meteorological observatory in Habana in1856; it was shut down, and he was forced to leave Cuba in 1869 due to the Ten Year's War (Figueredo and Argote-Freyre, 2008).

Mallet and Mallet - This worldwide catalog (Mallet and Mallet, 1858) of known earthquakes ends at 1842. The authors wrote that Perrey was publishing another yearly catalog of similar information, and therefore, they chose to end theirs with that year. Mallet and Mallet provide a summarized description for each event, but they also provide a list of references for the documents from which they obtained their information. Many of their sources are British and French biased, but they do include newspapers and scientific publications of the time. Events occurring on the same day in the same region tend to be grouped together as one event. For example, for the October 18, 1751, event there are reports for both Hispaniola and Martinique, but most likely, there were two distinct events occurring on the same day. As a consequence, some modern catalogues have attributed the large event felt in Hispaniola as also being felt in Martinique without further documentation. Many modern catalogues cite Mallet and Mallet as their source.

Perrey - The catalog of Caribbean earthquakes and subsequent yearly catalogs of world earthquakes (Perrey, 1843-1873) have been useful in tracking down the occurrence of these earthquakes, but descriptions are summarized much like those in Mallet and Mallet. On occasions when an earthquake caused enough news, Perrey provided a citation and a quotation of the damage done by the earthquake. Perrey published a catalog of earthquakes from 1843 to 1873.

Tippenhauer - This earthquake catalog is included as a chapter to the publication "Die Insel Haiti” published in 1893. Tippenhauer was initially interested in the science of meteorology by Father Wieck, director of the meteorological observatory at the Spiritans seminary school in Port-au-Prince, who visited Germany in 1885 (Bettembourg and others, 1952).

McCann and others-W. McCann, L. Feldman, and M. McCann generated a catalog of damage reports for the historical seismicity of Puerto Rico with some information on the Virgin Islands, Northern Lesser Antilles, and Hispaniola. Their work has been valuable for finding original sources from documents held by the Archivo General de Indias (AGI) that are cataloged online but as yet are not available to view online and Caribbean documents that also are not available to view online. A draft copy of their work was made available to the authors of this current report in 2005; the McCann and others report has now been published in "Revista Geofísica" (McCann and others, 2011). below.

Other significant ways of finding sources came through the use of the online databases listed

Google News Archives—http://news.google.com/newspapers During 2010, Google initiated a dedicated page for searching through digitized newspapers; however, as of August 2011, this page has been removed. Google now redirects users to their main news page and suggests the use of the advanced search feature. There is a similar feature for finding books digitized and available online for 
Google Books. An explanation on the Google Books Library project can be found at http://books.google.com/googlebooks/library.html.

Hemeroteca Digital-http://www.bne.es/opencms/es/Catalogos/HemerotecaDigital/index.html This site is hosted by the National Library of Spain (Biblioteca National de España) and is dedicated to newspapers published in Spain from the 17th to the 20th century. The National Library of Spain also hosts other online databases, which can be accessed from the main page at http://www.bne.es/es/Inicio/.

Gallica-http://gallica.bnf.fr/ This online database is hosted by the National Library of France (Bibliothèque national de France $-\mathrm{BnF}$ ). A user can access the library catalog and a search engine to look for all the library's available digitized material, such as manuscripts, journals, newspapers, maps, and images.

Portal de Archivos Españoles-http://pares.mcu.es/ This is the General Archive of the Indies, known as the Archivo General de Indias (AGI); it was established in 1785 in Seville, Spain, to gather all documents related to the Indies into one location. The Ministry of Culture of Spain provides an online database to search for documents in this archive and online viewing of digitized documents. The Ministry of Culture of Spain also hosts and connects to other Spanish databases that can be accessed at http://www.mcu.es/index.html.

Hathi Trust Digital Library—http://www.hathitrust.org/home This online database provides a useful catalog search engine for U.S. libraries for holdings and documents available in the public domain. The library has full text search for digitized documents. This site makes clear what resources are available online based on U.S. copyright laws and what, if any, holdings are a result of the Google digitizing project.

Internet Archives - http://www.arhive.org/ This online archive is a result of a not-for-profit organization's effort to build an internet library. It is useful for finding digital copies of historical books and documents that currently exist in libraries in the United States, and items can be downloaded from the site in various formats or viewed online.

Digital Library of the Caribbean-http://www.dloc.com/ This online archive is the result of a cooperative effort among Caribbean archives and libraries to preserve historical, cultural, and research materials and make them accessible to the public. Currently, this archive is administered by the Florida International University, in partnership with the University of the Virgin Islands and the University of Florida. A list of all founding partners and contributors can be viewed using a link at this site.

Further concerns for historical earthquake research include taking into account the century and standards of publications for the period; observations by governors and people of political importance tended to be published as either part of the government record or later as news reports about major events. Not until the late 19th century and early 20th century do commentaries from common people become more prominent in newspapers. Historians tend to distill much of the personal testimony, but sometimes a historical publication may be the only place in which edited testimony survives.

Testimonies from the Spanish colonial period of Hispaniola survive primarily through letters from governors to the King or from religious persons in requests for money to repair their colonial churches. Many of these documents survive in the Archivos General de Indias in Seville, Spain, and are cataloged. Only a small percentage of these documents are available online. Direct quotes from Archivo General de Indias letters are used in this report as source material where the original document is not available online or is not easy to obtain in publications, such as the history books written by de Utrera (1995) and Sevilla Soler (1980). 


\section{The bulletins from the Meteorological Observatory in Port-au-Prince, Haiti}

At the time of the publication of this report, the authors are aware of bulletins published by the l'Observatoire Meteorologique de Seminare-College St. Martial semi-annually first (1909 to 1916) and later annually (1917 to 1937 and 1950 to 1963). For the years 1935 to 1947, the college had no funds to publish a bulletin; therefore, information from those years was not published until 1950 (Bettembourg and others, 1952). The bulletins contain meteorological, as well as seismic, information, but for this report, only the chapters on seismology were used. Scherer was the sole compiler of the bulletins from 1909 to 1916. Scherer (director) and Baltenweck (sub-director) were co-compilers of the bulletins from 1920 to 1924. Bettembourg (director), Schneider (sub-director), and Schumacher (sub-director) were cocompilers of the bulletins from 1950 to 1955.

What is known about the Seminare-College St. Martial is that it was established by the Spiritans, also known as the Fathers of the Holy Ghost and the Holy Heart of Mary, in the middle of the 19th century. Father Weick, then professor of physics at the seminary school, established a meteorological observatory inside the old Fort Thomas in Port-au-Prince after 1878. Father Scherer took over as director of the observatory in 1886, shortly before Father Weick's death in 1887, and began to expand the capabilities of the observatory in 1890. Father Scherer installed pluviometers, also known as rain gauges, and established a correspondence network within parts of Haiti to collect a more complete record of the meteorology of Haiti. A transit telescope and chronometer, a precision clock, were acquired in 1896. With these, the observatory was able to report in mean local time which is $+04 \mathrm{~h} 49 \mathrm{~m}$ 21s of Greenwich time and changed the local time on February 1, 1917, to the median time for the 75th parallel at +05 h of Greenwich time. After 1913, the observatory adopted Greenwich Mean Time (GMT) to record seismic observations. Scherer had a Cecchi seismometer (vertical pendulum, 100 kilograms (kg)) installed in 1905 and about March 1911 had it replaced with an Omori-Bosch seismometer (SE-NW and SW-NE components, $71 \mathrm{~kg}$, and magnification of 30 times) at the observatory in Port-au-Prince. In 1950, the entire observatory was moved into a new building. All of this historical information comes from the bulletins published in the first few years, 1909-1912, and Bettembourg and others (1952). 


\section{Catalog of Earthquakes with Descriptions}

The reporting of the history of the region and of the natural hazards has evolved significantly. During the colonial period (15th to early 18th centuries), documentation of natural events was done either by those governing the colonies or by those employed by the church. Colonies exported their natural resources, and the church tithes supported the construction and maintenance of places of worship. Therefore, any event that might disrupt the flow of funds and resources to and from the colonies would most likely be documented as justification for additional funding for the repair of public and religious buildings or justification for the absence of the expected tithes. During the late 18th and all of the 19th and 20th centuries, many reports originated from news articles and journals, from catalogs of scientific societies, and later from geophysical observatories. For the 20th century, the catalog focuses on significantly large events before 1963. Most of the intensity data comes from the bulletins issued by of the l'Observatoire Meteorologique du Seminare-College St. Martial, which was renamed after 1953 Petit Seminare-College St. Martial, in Port-au-Prince, Haiti. At the time of writing this report, the authors are aware only of bulletins issued almost continuously by this observatory from 1909 to 1963; however, this observatory has been in existence since 1873 when it was established by Father Weick (Bettembourg and others, 1952).

This catalog is organized first by earthquakes predominantly felt on Hispaniola, followed by selected events felt in Puerto Rico, the Virgin Islands, and the Northern Lesser Antilles (see Index of Earthquakes by Island and by Year starting on page 187. The descriptions in the catalogue are in English, but some of the sources have been translated from Spanish, French, Italian, or German. Links to original works in the public domain are provided in the References Cited. Table 1 (page 178) lists the earthquakes studied in detail by Bakun and others (2012) and ten Brink and others (2011) with preferred locations and intensity magnitudes. Not all earthquakes listed in other catalogues have been included in this list; therefore, the list is not comprehensive for all earthquakes of the northeastern Caribbean. Each event is described in a table with five major components that are explained in detail below.

Header -The header contains the date, time, and a summary of the general effects of the earthquake. Only one earthquake is listed by its original date under the Julian calendar, that of December 2, 1562. Spain did not switch to the Gregorian calendar until 1582. Other Catholic nations that switched to the Gregorian calendar in 1582 are France, Portugal, and Poland; Germany and the Netherlands did not switch to the Gregorian calendar until 1700, and Great Britain did not adopt the calendar until 1752 (Guidoboni and Ebel, 2009). Earthquakes that occurred before the 20th century are referenced to the local time at the location with the highest relative intensity or at the only location with a time of day that is different than the origin time of the earthquake. An exact conversion to Universal Time (UTC) from an inexact description of the local time would only mislead the researcher for two important reasons. First, the convention of GMT as $0^{\circ}$ latitude was not adopted until 1884 (Guidoboni and Ebel, 2009), and second, the observatory in Port-au-Prince did not adopt mean local time, using precise astronomical and time clocks, until 1896. All events in the 20th century are listed with local mean time and the UTC equivalent or only in UTC if the earthquake occurred after 1913. In addition, instrumental origin times, location, and magnitudes are listed in the header in bold and are either from the Centennial Catalog (Engdahl and Villaseñor, 2002) or from Sykes and Ewing (1965). The rest of the header contains general information about the earthquake, including land-surface effects, such as liquefaction, mud volcanoes, subsidence, disruption of water flow; tsunami; submarine landslides; notes on aftershocks; and notes on other phenomena that may include a history, extent of damage, or other issues that do not fit into the previous categories; and finally, the number of locations with an associated observation. 
Longitude and Latitude-Geographical coordinates in degrees of latitude and longitude are listed for each location that has an earthquake-damage or felt description associated with it.

City-This is the name of the location of the city or town with an earthquake-damage or felt description. The list of cities in the tables is organized from the highest relative earthquake intensity to the lowest relative earthquake intensity. The name of the location at the time of the earthquake is listed first; if the name is different than the name of the location today, the current name is in parentheses. All locations are on the island of Hispaniola unless indicated by the name of the island after the name of the location. Because the Caribbean has a long history of changing boundaries and nationality, and because not all the islands in the Caribbean are independent nations, there is less confusion using the designation of city, island instead of city, country. A list of current locations for each city is provided in the appendix on page 220

Description-Each earthquake description begins with a citation, followed by the description of damage from that source. Multiple descriptions for each location are organized by source, from those published closest to the time of the earthquake to the most recent. In the case of de Utrera (1995), the first edition of that work was published in 1927; therefore, it would go before source material published after 1927. For some locations, the same source is assigned to different locations nearby. For the research work done by, and described in, Bakun and others (2012) and ten Brink and others (2011), listing each location uniquely instead of grouping them into one single description of damage was necessary. As a result, for this catalog, this convention of listing each location uniquely was adopted with the intention of easily transitioning these locations into mapping software or to a geographic information system (GIS) software mapping tool. In the description field of each earthquake table, the following three font styles are used to indicate to the reader the manner in which the sources are cited.

1. Arial, 9pt is used to indicate text that is paraphrased from the original text by the authors.

2. Times New Roman, 11pt is used to indicate text directly quoted from the source, independent of original language.

3. Times New Roman, 11pt, italics is used to indicate text in which the source is quoting another source.

Intensity-This last column contains the assigned Mercalli Intensities, if available, and is ordered from the most recent to the oldest. Author assigned Modified Mercalli Intensity values are based on criteria listed in table 2, page 179. In the Intensity column, assigned moment intensities from other publications are indicated in the following shorthand: C1972 $=$ Campbell (1972), LB1948 $=$ Lynch and Bodle (1948), S\&L1992 = Shepherd and Lynch (1992), L\&S1995 = Lynch and Shepherd (1995), T\&R1977 = Tomblin and Robson (1977), SISF = SisFrance/Antilles (2010); the assigned intensities by the authors are $\mathrm{CHF}=$ Claudia $\mathrm{H}$. Flores and WHB $=$ William H. Bakun. Intensities are shown in Arabic numbers instead of Roman numerals. Bakun (WHB) intensities are generally more conservative than Flores (CHF) intensities, and (-) signifies that the authors did not find sufficient detail to allow an intensity assignment or that the event was not large enough to necessitate an intensity assignment. 


\section{Earthquakes from 1500 to the end of the 17th Century:}

Intensity, Mercalli Magnitude Intensities (3-10); CHF, assigned by C. H. Flores (author); WHB, assigned by W. H. Bakun (author); SISF, assigned by SiSFrance/Antilles (2010); S\&L1992, assigned by Shepherd and Lynch (1992); C1972, assigned by Campbell (1972); -, no assignment given.

\section{December 2, 1562 (Julian Calendar) \\ Time: Between 8 and 9 in the evening, Conception de la Vega local time.}

Phenomenon Notes: Earthquake resulted in the relocation of Santiago de los Caballeros and Conception de la Vega. In many catalogs this event is listed as occurring in the year 1564, either in April or September, and this date is taken from a personal letter written by Echagoian and later from Garcia's (1900) work on the history of Santo Domingo. From de Utrera (1995), the day and year of this earthquake used in this catalog is taken from four letters written contemporaneously and stored in the Archivo General de Indias (AGI) archives in Seville, Spain. From Utrera (1995), "Let us abide to Echagoian but not by his single and personal testimony because in the Archive of the Indies we find the following papers: Letter from the honorable Herrera to His Majesty, in the Real Council of the Indies, over various matters and among them news of an earthquake that occurred December 2 of the year before which is dated February 16, 1563. Another letter dated February 13, 1563 signed by the Honorable Herrera, the honorable Echagoian and by the doctor Caceres to His Majesty, in the Real Council of the Indies, about the earthquake that occurred on December 2 of the year before, between eight and nine at night, which resulted in the fall of the church cathedral in la Vega. Another letter from the ecclesiastical Council from Conception de la Vega to His Majesty, in the Real Council of de Indies, over the destruction caused by the earthquake of December 2, 1562 and this is a letter dated October 6, 1563.” Moreau de St. Méry (1798 describes the ruins of the original establishment of La Vega where masonry work was found to have had iron bars, and Scherer (1912) cites Moreau de St. Méry.

Number of Observations: 6

\begin{tabular}{|c|c|c|c|c|}
\hline Longitude & Latitude & City & Description & Intensity \\
\hline-70.7075 & 19.4502 & Santiago de los Caballeros & $\begin{array}{l}\text { (del Monte y Tejada, 1890): The city of La Vega was not the only one to be } \\
\text { destroyed by the great shaking; the city of Santiago de los Caballeros which } \\
\text { had been built in the plain that formed the ranches of Jacagua and Gurabito fell } \\
\text { to its foundations and its dwellings saw the same fate as those in La Vega. } \\
\text { (de Utrera, 1995): Entire city destroyed to the ground. By this time the church was built } \\
\text { of masonry. }\end{array}$ & $\begin{array}{l}\text { CHF(8) } \\
\text { WHB(9) } \\
\text { SISF(8) } \\
\text { S\&L1992(9) } \\
\text { C1972(9) }\end{array}$ \\
\hline-70.5442 & 19.2937 & $\begin{array}{l}\text { Concepción de la Vega } \\
\text { (old ruin) }\end{array}$ & $\begin{array}{l}\text { (Moreau de St. Méry, 1796): An earthquake toppled almost the entire city. } \\
\text { (Scherer, 1912a): The ruins of the old city were found in } 1798 \text { and were described by } \\
\text { the author: brick columns which the mortar held together perfectly. The arch of } \\
\text { the church, the steeple, and the capitals of the columns were on the ground, but } \\
\text { in blocks; and these columns had three inch bars of iron running through their } \\
\text { length. } \\
\text { (de Utrera, 1995): The church and Franciscan monastery were built of stone masonry } \\
\text { by this time. } \\
\text { The monastery fell and almost the entire church fell to the ground except for } \\
\text { the section were the cross stood and this occurred sometime between } 8 \text { and } 9 \text { in }\end{array}$ & $\begin{array}{l}\text { CHF(9) } \\
\text { WHB(8.5) } \\
\text { SISF(8.5) } \\
\text { S\&L1992(9) } \\
\text { C1972(9) }\end{array}$ \\
\hline
\end{tabular}




\begin{tabular}{|c|c|c|c|c|}
\hline \multicolumn{5}{|c|}{ December 2, 1562 (Julian Calendar) } \\
\hline & & & the evening. & \\
\hline-70.6937 & 19.7971 & Puerto Plata & $\begin{array}{l}\text { (de Utrera, 1995): The dormitory and the convent that was part of it in the Dominican } \\
\text { monastery were severely damaged and were the only buildings made out of brick and } \\
\text { stone in the town. } \\
\text { In } 1575 \text { the Dominicans of Puerto Plata wrote a petition for help for their } \\
\text { damaged church } * * * \text { the following was written: } * * * \text { You do know that after } \\
\text { it (the monastery) was again rebuilt and after having cost so much, the } \\
\text { dormitory of the before mentioned monastery fell again from an earthquake } \\
\text { that occurred in the year of sixty-two. }\end{array}$ & $\begin{array}{l}\mathrm{CHF}(7) \\
\operatorname{WHB}(7)\end{array}$ \\
\hline-69.8877 & 18.4722 & Santo Domingo & $\begin{array}{l}\text { (de Utrera, 1995): In this city [Santo Domingo] there was a clergyman by the } \\
\text { name of Alonso de Peña } * * * \text { gave everything to the church, by luck that today } \\
\text { this clergyman is the only one of his contemporaries that has passed through } \\
\text { history the admirable aura of having given aid with all his properties for the } \\
\text { material and moral restoration of the island after the terrible earthquake of } \\
\text { December } 2,1562 . \\
\text { Part of the letter to canonize Peña dated April 20, 1576: ( } * * * \text { who has given great } \\
\text { service to God and his Royal Highness, has built three important churches, our } \\
\text { Lady of High Grace in the village of Savaleon de Higuey [...] built the church } \\
\text { in the city of Santiago de los Caballeros and is today building the parish of } \\
\text { Santa Barbara of this city of Santo Domingo } * * *) \text { The parish of Santa Barbara } \\
\text { was built in } 1536 \text { with mud walls. }\end{array}$ & $\begin{array}{l}\text { CHF(6) } \\
\text { WHB(7) } \\
\text { S\&L1992(4) } \\
\text { C1972(3) }\end{array}$ \\
\hline-71.6507 & 19.8474 & Monte Cristi & $\begin{array}{l}\text { (K. Deagan, Florida Museum of Natural History, written commun., } 2011 \text { quoting Archivo } \\
\text { General de Indias source dated May 13, 1563): A witness on board a vessel at Monte } \\
\text { Cristi saw the earth shake ashore in 1562. }\end{array}$ & - \\
\hline- & - & $\begin{array}{l}\text { Puerto Real } \\
\text { (near Fort Liberte today) }\end{array}$ & $\begin{array}{l}\text { (K. Deagan, Florida Museum of Natural History, written commun., 2011): There is no } \\
\text { archeological evidence for severe earthquake damage during the } 1562 \text { earthquake. The } \\
\text { town was burned and abandoned in } 1578 \text { by Spanish authorities because of failure to } \\
\text { restrict contraband trade by the locals. }\end{array}$ & - \\
\hline
\end{tabular}

\section{September 7, 1615}

Time: Between 11 and 12 at night, San Juan, Puerto Rico local time.

Aftershocks: Strong aftershocks that lasted for 40 days with 3 to 4 shocks per day (de Utrera, 1995).

Phenomenon Notes: Earthquake was reported to have been felt all over the island. A hurricane occurred days after this earthquake starting September 12,1615

(McCann and others, 2011). There are accounts of damages from both the hurricane and earthquake in the countryside but are not separated as such.

Number of Observations: 2

\begin{tabular}{|l|l|l|l|l|}
\hline Longitude & Latitude & City & Description & Intensity \\
\hline-69.8877 & 18.4722 & Santo Domingo & (McCann and others, 2011 quoting AGI letter dated July 4, 1623, ref 1, Doc. 166): & CHF(8) \\
\hline
\end{tabular}




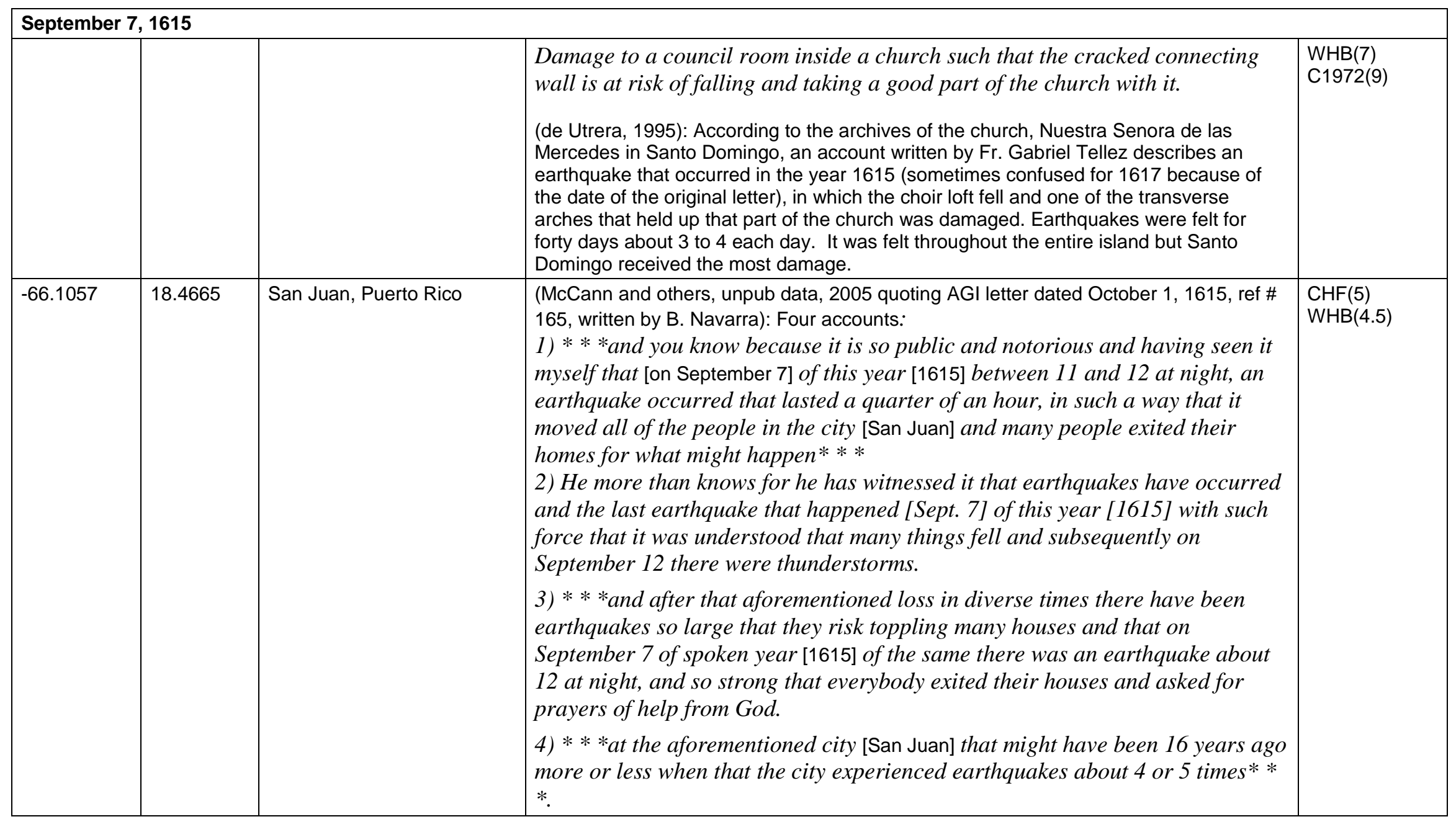

\section{January, 1665}

Time: Unknown

Phenomenon Notes: Not reported in Puerto Rico.

Number of Observations: 2

\begin{tabular}{|l|l|l|l|l|}
\hline Longitude & Latitude & City & Description & Intensity \\
\hline-69.8877 & 18.4722 & Santo Domingo & $\begin{array}{l}\text { (de Utrera, 1995 quoting Archivo General de Indias letter dated January 15, 1665): } \\
\text { The archbishop Cueva y Maldonado writes to the king to say that he had done }\end{array}$ & $\begin{array}{l}\text { CHF(7) } \\
\text { WHB(6) } \\
\text { C1972(6) }\end{array}$ \\
\hline
\end{tabular}




\begin{tabular}{|l|l|l|l|}
\hline January, 1665 & & $\begin{array}{l}\text { the required repairs to the main church and convent in Santo Domingo in } \\
\text { which they had been damaged by an earthquake and that the year has started } \\
\text { with earthquake. }\end{array}$ \\
\hline-70.8359 & 18.3504 & Old Azua & $\begin{array}{l}\text { (de Utrera, 1995): Similar letter from the same archbishop saying that the church in } \\
\text { Azua had been ruined by an earthquake and had ordered its repair. De Utrera thinks it } \\
\text { is most likely from an earthquake in 1665. }\end{array}$ \\
\hline
\end{tabular}

\begin{tabular}{|c|c|c|c|c|}
\hline \multicolumn{5}{|l|}{ May 9,1673} \\
\hline \multicolumn{5}{|c|}{$\begin{array}{l}\text { Time: Unknown } \\
\text { Phenomenon Notes: Probably felt in other parts of the island but no individual reports. } \\
\text { Number of Observations: } 2\end{array}$} \\
\hline Longitude & Latitude & City & Description & Intensity \\
\hline-69.8877 & 18.4722 & Santo Domingo & $\begin{array}{l}\text { (Garcia, 1900): The earthquake caused much damage and some loss of life, five } \\
\text { in the city of Santo Domingo***and probably much harm was caused in the } \\
\text { rest of the island. } \\
\text { (de Utrera, 1995): According to the archives in the church of San Lazaro in Santo } \\
\text { Domingo, an earthquake left the entire city in ruins. So much damage was done that the } \\
\text { governess of New Spain called to all the subjects to donate funds to repair the homes, } \\
\text { forts, churches and hospitals. Of the } 2000 \text { pesos, } 200 \text { pesos went to the hospital of San } \\
\text { Lazaro and } 150 \text { pesos went to the repair of the Dominican church and convent of San } \\
\text { Nicolas. "An earthquake occurred with such force that it ruined all of the houses in the } \\
\text { city". }\end{array}$ & $\begin{array}{l}\text { CHF(8) } \\
\text { WHB(9) } \\
\text { C1995(10) } \\
\text { S\&L1992(8) }\end{array}$ \\
\hline-70.8359 & 18.3504 & Old Azua & (Taber, 1922): City damaged by earthquake. & $\begin{array}{l}\mathrm{CHF}(6) \\
\mathrm{WHB}(6)\end{array}$ \\
\hline
\end{tabular}

\section{4}

Time: Unknown

Phenomenon Notes: Felt and possible minor damages in other towns.

Number of Observations: 2

\begin{tabular}{|c|c|c|c|c|}
\hline Longitude & Latitude & City & Description & Intensity \\
\hline-69.8877 & 18.4722 & Santo Domingo & $\begin{array}{l}\text { (Moreau de St. Méry, 1796): Of the buildings that survived Drake's invasion, they } \\
\text { were lost in the } 1684 \text { and } 1691 \text { earthquakes. } \\
\text { (Moreau de St. Méry, 1798): The Spanish part of the island suffered cruelly. } \\
\text { (Tippenhauer, 1893): Suffered very much. }\end{array}$ & $\begin{array}{l}\mathrm{CHF}(8) \\
\text { WHB(8) } \\
\text { SISF(8) }\end{array}$ \\
\hline
\end{tabular}




\begin{tabular}{|l|l|l|l|l|}
\hline 1684 & & & $\begin{array}{l}\text { (Garcia, 1900): A most terrible earthquake left most of the cities almost in ruin } \\
\text { but it particularly hit Santo Domingo the hardest. Many churches, official and } \\
\text { public buildings had to be rebuilt in the city. } \\
\text { (de Utrera, 1995): A diocesan makes reference to damage suffered on the island as } \\
\text { the reason why it has been difficult for the inhabitants to fulfill their tithe obligations to } \\
\text { the church in a letter written in 1685. }\end{array}$ \\
\hline-70.8359 & 18.3504 & Old Azua & (Tippenhauer, 1893): Suffered very much. & $\begin{array}{l}\text { CHF(5) } \\
\text { WHB(6) }\end{array}$ \\
\hline
\end{tabular}

\begin{tabular}{|c|c|c|c|c|}
\hline \multicolumn{5}{|l|}{1691} \\
\hline Longitude & Latitude & City & Description & Intensity \\
\hline-70.8359 & 18.3504 & Old Azua & $\begin{array}{l}\text { (Moreau de Jonnes, 1822): Listed as a very destructive earthquake that destroyed } \\
\text { the city of Azua and also one of many earthquakes that have been most } \\
\text { destructive in the Antilles. } \\
\text { (Perrey, 1843; Mallet and Mallet, 1858): It destroyed the town of Azua. } \\
\text { (Perrey, 1847): It was destroyed by an earthquake. } \\
\text { (Tippenhauer, 1893): Suffered very much. }\end{array}$ & $\begin{array}{l}\text { CHF(8) } \\
\text { WHB(8) } \\
\text { SISF(8) } \\
\text { S\&L1992(9) }\end{array}$ \\
\hline
\end{tabular}




\section{Earthquakes of the 18th Century:}

Intensity, Mercalli Magnitude Intensities (3-10); CHF, assigned by C. H. Flores (author); WHB, assigned by W. H. Bakun (author); SISF, assigned by SiSFrance/Antilles (2010); S\&L1992, assigned by Shepherd and Lynch (1992); T\&R1977, Tomblin and Robson (1977); C1972, assigned by Campbell (1972); -, no assignment.

\begin{tabular}{|c|c|c|c|c|}
\hline \multicolumn{5}{|c|}{ November 9, 1701} \\
\hline \multicolumn{5}{|c|}{$\begin{array}{l}\text { Time: Unknown } \\
\text { Land Surface Effects: Landslides observed on the road between Leogane and Petit Goave. } \\
\text { Tsunami: Some previous catalogues have associated a minor tsunami with this event based on the damage descript } \\
\text { translated Moreau de Saint Méry, (1798). The original French text is as follows, "Le } 9 \text { Novembre 1701, le tremble } \\
\text { fraîchement élevées dans la plaine, \& fit affaler des parties du chemin qui conduisait le long de la mer, de } \\
\text { Méry, 1798) See the Leogane description for the English translation. } \\
\text { Phenomenon Notes: This is the first major earthquake documented on the western side of the island of Hispaniola. } \\
\text { Number of Observations: } 5\end{array}$} \\
\hline Longitude & Latitude & City & Description & Intensity \\
\hline-72.6334 & 18.5111 & Leogane & $\begin{array}{l}\text { (Moreau de St. Méry, 1798): Taber (1922) and Scherer (1912a) translate Moreau } \\
\text { de St. Méry (1798) as: It caused more destruction in the plain (Cul-de-Sac). } \\
\text { Several houses built of masonry were thrown down and the road which } \\
\text { leads from Leogane to Petit Goave along the sea shore sank into the sea. } \\
\text { Our English translation: The November 9, } 1701 \text { earthquake toppled } \\
\text { masonry freshly built in the plain and collapsed parts of the path which led } \\
\text { along the sea from Leogane to Petit Goave. } \\
\text { (Tippenhauer, 1893): Quite Strong. } \\
\text { (Garcia, 1900): The earthquake of } 1701 \text { caused great destruction in various } \\
\text { villages especially at Leogane, and in the French part of the island. }\end{array}$ & $\begin{array}{l}\operatorname{CHF}(7) \\
\text { WHB(7) } \\
\text { S\&L1992(7) } \\
\text { SISF(8) }\end{array}$ \\
\hline-72.8668 & 18.4315 & Petit Goave & $\begin{array}{l}\text { (Moreau de St. Méry, 1798): The November 9, } 1701 \text { earthquake toppled } \\
\text { masonry freshly built in the plain and collapsed parts of the path which led } \\
\text { along the sea from Leogane to Petit Goave. }\end{array}$ & $\begin{array}{l}\mathrm{CHF}(6) \\
\mathrm{WHB}(7)\end{array}$ \\
\hline-72.2808 & 18.6042 & Cul-de-Sac & (Scherer, 1912a): It caused more destruction in the plain [Cul-de-Sac]. & $\begin{array}{l}\mathrm{CHF}(6) \\
\operatorname{WHB}(6) \\
\operatorname{SISF}(7)\end{array}$ \\
\hline-69.8877 & 18.4722 & Santo Domingo & $\begin{array}{l}\text { (Moreau de St. Méry, 1798): The Spanish side of the island felt its cruel } \\
\text { effects. } \\
\text { (Moreau de Jonnes, 1822): Damages "It was disastrous", [in reference to the } \\
\text { whole island] }\end{array}$ & $\begin{array}{l}\mathrm{CHF}(4) \\
\mathrm{WHB}(5)\end{array}$ \\
\hline
\end{tabular}




\begin{tabular}{|l|l|l|l|}
\hline \multicolumn{2}{|l|}{ November 9, 1701} & & $\begin{array}{l}\text { (Tippenhauer, 1893): Quite Strong. } \\
\text { (de Utrera, 1995): In Santo Domingo. }\end{array}$ \\
\hline-72.2006 & 19.7616 & Cap Haitien & (Moreau de St. Méry, 1798): Earthquake felt strongly. \\
\hline
\end{tabular}

\section{3}

Time: Unknown

Phenomenon Notes: None

Number of Observations: 2

\begin{tabular}{|l|l|l|l|l|}
\hline Longitude & Latitude & City & Description \\
\hline-69.8877 & 18.4722 & Santo Domingo & $\begin{array}{l}\text { (Moreau de St. Méry, 1798): The Spanish side of the island felt its cruel } \\
\text { effects. } \\
\text { (Moreau de Jonnes, 1822): It was disastrous. [in reference to the whole island] } \\
\text { (Tippenhauer, 1893): Strong }\end{array}$ \\
\hline-72.2006 & 19.7616 & Cap Haitien & $\begin{array}{l}\text { (Tippenhauer, 1893): Strong } \\
\text { (Moreau de St. Méry, 1798): Earthquake felt strongly. }\end{array}$ \\
\hline
\end{tabular}

\section{4}

Time: Unknown

Phenomenon Notes: None

Number of Observations: 3

\begin{tabular}{|l|l|l|l|l|}
\hline Longitude & Latitude & City & Description \\
\hline-69.8877 & 18.4722 & Santo Domingo & $\begin{array}{l}\text { (Moreau de St. Méry, 1798): The Spanish side of the island felt its cruel } \\
\text { effects. } \\
\text { (Moreau de Jonnes, 1822): An earthquake on the island. } \\
\text { (Tippenhauer, 1893): quite strong }\end{array}$ \\
\hline-72.3388 & 18.5432 & Port-au-Prince & $\begin{array}{l}\text { CHF(4) } \\
\text { (de Utrera, 1995): On the island, very strong shaking. }\end{array}$ \\
\hline-72.2006 & 19.7616 & Cap Haitien & (Tippenhauer, 1893): quite strong \\
\hline
\end{tabular}




\begin{tabular}{|c|c|c|c|c|}
\hline \multicolumn{5}{|c|}{ May 15,1751} \\
\hline \begin{tabular}{|l} 
Longitude \\
\end{tabular} & Latitude & City & Description & Intensity \\
\hline
\end{tabular}

\section{May 25, 1751}

Time: between 12 and 1 at night, Santo Domingo local time

Phenomenon Notes: None

Number of Observations: 2

\begin{tabular}{|l|l|l|l|l|}
\hline Longitude & Latitude & City & Description \\
\hline-69.8877 & 18.4722 & Santo Domingo & $\begin{array}{l}\text { (Mallet and Mallet, 1858): Earthquake between 12 and 1 at night (on the } \\
\text { island). } \\
\text { (Tippenhauer, 1893): Earthquake }\end{array}$ \\
\hline-72.2006 & 19.7616 & Cap Haitien & $\begin{array}{l}\text { (Gentleman's Magazine,1753): The first shock was on May 25, 1751, between } \\
\text { 12 and 1 o'clock at night, it was pretty considerable, but few people felt it. } \\
\text { However the reality by letters from several parts of the island, but as it did } \\
\text { no damage, it caused no alarm. }\end{array}$ \\
\hline
\end{tabular}

\section{September 15,1751}

Time: $10: 00$ at night, Santo Domingo local time

Phenomenon Notes: None

Number of Observations: 2

\begin{tabular}{l|l|l}
\hline Longitude & Latitude & City
\end{tabular}




\begin{tabular}{|l|l|l|l|l|}
\hline \multicolumn{2}{|l|}{ September 15, 1751 } & Santo Domingo & $\begin{array}{l}\text { (Perrey, 1843): At 10 in the evening, several shocks. } \\
\text { (Mallet and Mallet, 1858): Earthquake, several shocks. } \\
\text { (Tippenhauer, 1893): Earthquake, at 10 o'clock in the evening. } \\
\text { (de Utrera, 1995): Felt all over the island. }\end{array}$ \\
\hline-72.3388 & 18.4722 & $\begin{array}{l}\text { Shepherd and Lynch (1992) quote Lyell (1875) but Shepherd and Lynch mention in } \\
\text { their notes that this description is very similar to the later major earthquake of } \\
\text { October 18, 1751 }\end{array}$ & \begin{tabular}{l} 
S\&1992(9) \\
\hline
\end{tabular} \\
\hline
\end{tabular}

\section{September 29, 1751}

Time: unknown

Phenomenon Notes: More than one shock was felt on this day according to de Mairan, 1756.

Number of Observations: 1

\begin{tabular}{|l|l|l|l|l|}
\hline Longitude & Latitude & City & Description \\
\hline-69.8877 & 18.4722 & Santo Domingo & $\begin{array}{l}\text { (de Mairan, 1756): On the 29, several earthquakes [occurred] which we did } \\
\text { not pay much attention to. } \\
\text { (Mallet and Mallet, 1858): Earthquake. } \\
\text { (Tippenhauer, 1893): Earthquake. } \\
\text { (de Utrera, 1995): Felt all over the island. }\end{array}$ \\
\hline
\end{tabular}

\section{October 8, 1751}

\section{Time: unknown}

Phenomenon Notes: Possible foreshock?

Number of Observations: 2

\begin{tabular}{|l|l|l|l|l|}
\hline Longitude & Latitude & City & Description \\
\hline-69.8877 & 18.4722 & Santo Domingo & $\begin{array}{l}\text { (Mallet and Mallet, 1858): Earthquake. } \\
\text { (Tippenhauer, 1893): Earthquake. } \\
\text { (de Utrera, 1995): Felt in Santo Domingo. }\end{array}$ \\
\hline-72.2006 & 19.7616 & Cap Haitien & $\begin{array}{l}\text { (Gentleman's Magazine, 1753): On Oct. 8, following, another slight shock was } \\
\text { felt, and a like shock on the 12th about noon, but on the 18th was a terrible }\end{array}$ \\
\hline
\end{tabular}




\begin{tabular}{|l|l|l|l|l|}
\hline October 8, 1751 & & shock. \\
\hline & & & \\
\hline
\end{tabular}

\begin{tabular}{|c|c|c|c|c|}
\hline \multicolumn{5}{|c|}{ October 12, 1751} \\
\hline \multicolumn{5}{|c|}{$\begin{array}{l}\text { Time: about noon, Cap Haitien local time } \\
\text { Phenomenon Notes: Possible foreshock? } \\
\text { Number of Observations: } 2\end{array}$} \\
\hline Longitude & Latitude & City & Description & Intensity \\
\hline
\end{tabular}

\section{October 18, 1751}

Time: About 3:00 in the afternoon, Santo Domingo local time

Land Surface Observations: Sulfur springs appeared in the mountains north of the town of Azua.

Tsunami: Previous catalogues associate a tsunami with this event flooding the town of Azua. With closer inspection of the historical record, it is documented that hurricanes hit Hispaniola on August 21 contributing to flooding all over the southern coasts of the island (Sevilla Soler, 1980) and during the month of September that hit Jamaica from the 18 to 20th resulting in loss of many ships at sea but "In Hispaniola, only a few chimneys and slight buildings were blown down," [in Cape Haitien] (Gentleman's Magazine, 1751a,b). The hurricane is documented in earlier catalogues and described by a contemporary of the period (see Old Azua). The ruins of the old city of Azua were actually located about $6 \mathrm{~km}$ inland at an elevation of 23 meters in present day Pueblo Viejo, Dominican Republic.

Aftershocks: A major aftershock was felt at 5 o'clock in the evening that same day and the next major aftershock on Oct. 28 (three tremors felt) and Oct. 29 (two tremors felt). Minor tremors were felt for the rest of the month of October into the month of November.

Phenomenon Notes: The earthquake destruction contributed to the relocation of the towns of Azua and Seibo to their modern locations. Azua was relocated to the foot of the Cibao mountains; Seibo was relocated a few kilometers north further up and on the other side of the river. Previous earthquakes before this day may or may not have been foreshocks to this event.

Number of Observations: 14

\begin{tabular}{|l|l|l|l|}
\hline Longitude & Latitude & City & Description \\
\hline-69.8877 & 18.4722 & Santo Domingo & $\begin{array}{l}\text { (Sevilla Soler, 1980, quoting letter written by Franciso Rubio y Peñaranda Oct. 19, } \\
\text { 1751, Archivo General de Indias, Santo Domingo, ref \# 942): } * * * \text { a bit after 3 } \\
\text { o'clock an attack in the space of 6 minutes, without pause, such a strong } \\
\text { earthquake } * * \text { from its impulsive subterranean roar felt and violent } \\
\text { motion on all the churches and buildings, such that all of those of masonry } \\
\text { S\&L1992(8) } \\
\text { T\&R1977(8) } \\
\text { C1972(10) }\end{array}$ \\
\hline
\end{tabular}




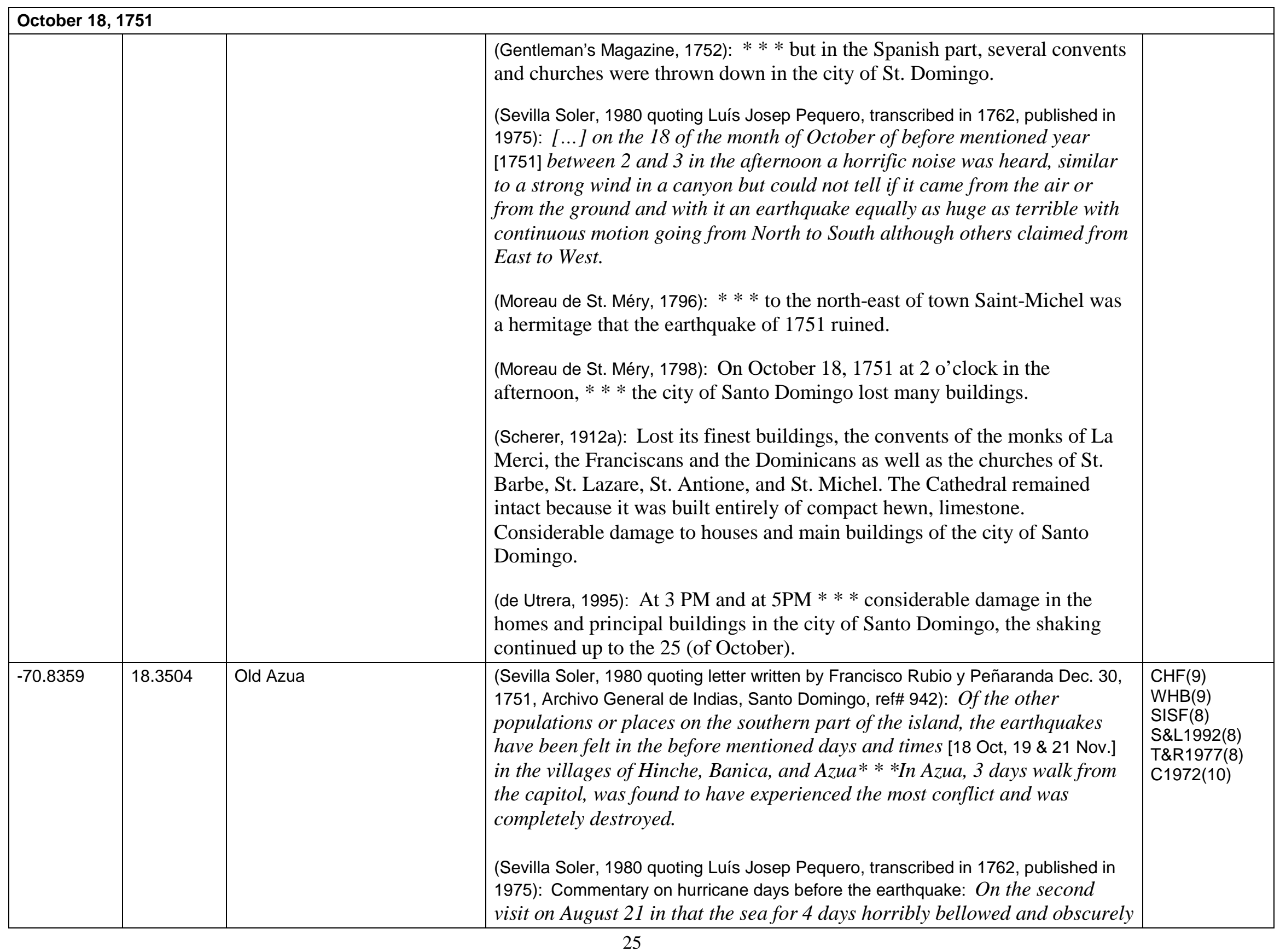




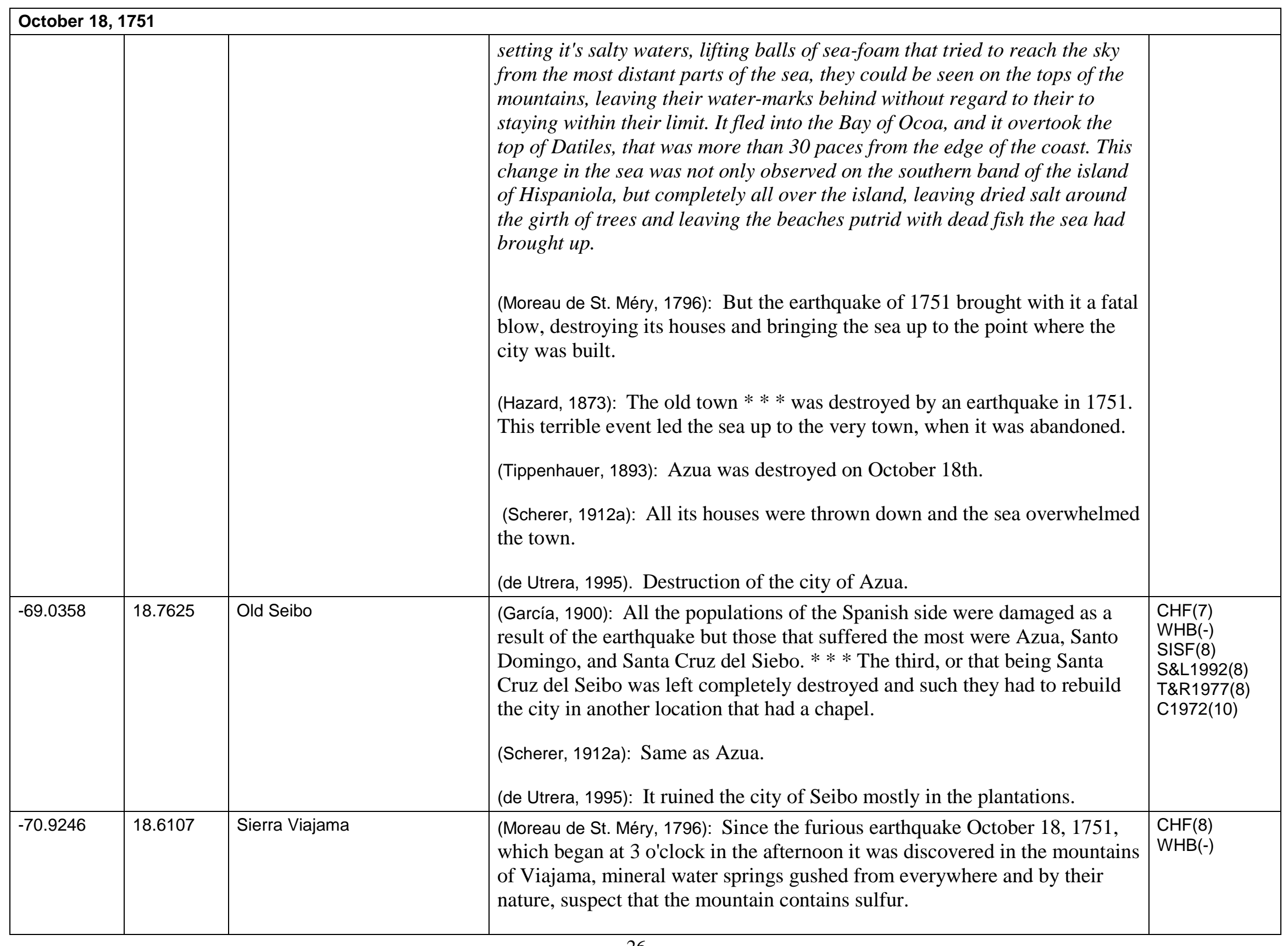




\begin{tabular}{|c|c|c|c|c|}
\hline \multicolumn{5}{|c|}{ October 18,1751} \\
\hline & & & $\begin{array}{l}\text { (Scherer, 1912a): Northward from Azua in the Sierra Viajama, one of the } \\
\text { ranges of Cibao, sulfur springs appeared. }\end{array}$ & \\
\hline-71.2325 & 18.8074 & San Juan de Maguana & $\begin{array}{l}\text { (Sevilla Soler, } 1980 \text { quoting letter written by Francisco Rubio y Peñaranda Dec. 30, } \\
\text { 1751, Archivo General de Indias, Santo Domingo, ref\# 942): From here [Azua] the } \\
\text { nearby villages of Neyba and San Juan, in various places the earth opened } \\
\text { and swallowed several animals and one man haven fallen into a crevasse } \\
\text { was found to have many injuries. }\end{array}$ & $\begin{array}{l}\text { CHF(7) } \\
\text { WHB(-) }\end{array}$ \\
\hline-71.7074 & 19.0793 & Banica & $\begin{array}{l}\text { (Gentleman's Magazine, 1752): } * * * \text { a Spanish village, Baniquo was entirely } \\
\text { swallowed up, and a sort of saltish lake appeared in its place. } \\
\text { (Sevilla Soler, 1980, quoting letter written by Francisco Rubio y Peñaranda Dec. } 30, \\
1751, \text { Archivo General de Indias, Santo Domingo, ref\# 942): Of the other } \\
\text { populations or places on the southern part of the island, the earthquakes } \\
\text { have been felt in the before mentioned days and times [18 Oct, } 19 \text { \& } 21 \text { Nov.] } \\
\text { in the villages of Hinche, Banica, and Azua *** In Banica we have also } \\
\text { received similar news, put since they are such a poor village and infertile, } \\
\text { they have only been companions in experiencing fear. }\end{array}$ & $\begin{array}{l}\mathrm{CHF}(6) \\
\mathrm{WHB}(-)\end{array}$ \\
\hline-72.0107 & 19.1453 & Hinche & $\begin{array}{l}\text { (Sevilla Soler, 1980, quoting letter written by Francisco Rubio y Peñaranda Dec. } 30, \\
\text { 1751, Archivo General de Indias, Santo Domingo, ref\# 942): Of the other } \\
\text { populations or places on the southern part of the island, the earthquakes } \\
\text { have been felt in the before mentioned days and times [18 Oct, } 19 \text { \& } 21 \text { Nov.] } \\
\text { in the villages of Hinche, Banica, and Azua, and the first location with such } \\
\text { violence that all the maize crops and large trees in the field were detached } \\
\text { from the ground by the roots *** their church had fallen to the ground it } \\
\text { being built of stone. }\end{array}$ & $\begin{array}{l}\mathrm{CHF}(7) \\
\mathrm{WHB}(7)\end{array}$ \\
\hline-70.5327 & 19.2239 & La Vega & $\begin{array}{l}\text { (Sevilla Soler, 1980, quoting letter written by Francisco Rubio y Peñaranda Dec. 30, } \\
\text { 1751, Archivo General de Indias, Santo Domingo, ref\# 942): "In the Northern } \\
\text { section it was equally experienced in the cities of Santiago, Vega, and the } \\
\text { town of Cotuy [Cotui]." As a result the majority of the buildings were found } \\
\text { to be in ruins, and according to the governor, the majority of the population, } \\
\text { including the governor, found themselves forced to live in the barracks. }\end{array}$ & $\begin{array}{l}\mathrm{CHF}(6) \\
\mathrm{WHB}(7)\end{array}$ \\
\hline
\end{tabular}




\begin{tabular}{|c|c|c|c|c|}
\hline \multicolumn{5}{|c|}{ October 18, 1751} \\
\hline-70.7075 & 19.4502 & Santiago de los Caballeros & $\begin{array}{l}\text { (Sevilla Soler, } 1980 \text { quoting letter written by Francisco Rubio y Peñaranda Dec. 30, } \\
\text { 1751, Archivo General de Indias, Santo Domingo, ref\# 942): "In the Northern } \\
\text { section it was equally experienced in the cities of Santiago, Vega, and the } \\
\text { town of Cotuy [Cotui]." As a result the majority of the buildings were found } \\
\text { to be in ruins, and according to the governor, the majority of the population, } \\
\text { including the governor, found themselves forced to live in the barracks. }\end{array}$ & $\begin{array}{l}\mathrm{CHF}(6) \\
\operatorname{WHB}(7)\end{array}$ \\
\hline-70.1531 & 19.0577 & Cotui & $\begin{array}{l}\text { (Sevilla Soler, } 1980 \text { quoting letter written by Francisco Rubio y Peñaranda Dec. 30, } \\
\text { 1751, Archivo General de Indias, Santo Domingo, ref\# 942): "In the Northern } \\
\text { section it was equally experienced in the cities of Santiago, Vega, and the } \\
\text { town of Cotuy [Cotui]". As a result the majority of the buildings were found } \\
\text { to be in ruins, and according to the governor, the majority of the population, } \\
\text { including the governor, found themselves forced to live in the barracks. }\end{array}$ & $\begin{array}{l}\mathrm{CHF}(6) \\
\mathrm{WHB}(7)\end{array}$ \\
\hline-72.3400 & 18.5400 & Port-au-Prince & $\begin{array}{l}\text { (Gentleman's Magazine, 1752): On Oct, 18th last, about } 2 \text { in the afternoon, ** } \\
\text { * the earth shook violently; a steeple was thrown down and a few houses } \\
\text { demolished in the French part of the island. } \\
\text { (de Mairan, 1756): On the } 18 \text { of October, we felt one violent enough on the } \\
\text { French side, but caused little damage. There were others frequent but barely } \\
\text { felt until the } 31 \text { and the earth continued to have strong movement, though } \\
\text { not marked tremors until [Nov] } 21 . \\
\text { (Moreau de St. Méry, 1798): On the } 18 \text { of October 1751, at two o'clock in the } \\
\text { afternoon *** the earth shook in Port-au-Prince with two violent shakes } \\
\text { that lasted } 3 \text { minutes. } \\
\text { (Scherer, 1912a): The earth trembled } * * * \text { with two violent shocks, which } \\
\text { lasted } 3 \text { minutes. }\end{array}$ & $\begin{array}{l}\text { CHF(5) } \\
\text { WHB(6) } \\
\text { SISF(7) }\end{array}$ \\
\hline-72.2273 & 18.5758 & Croix de Bouquets & $\begin{array}{l}\text { (Moreau de St. Méry, 1798): On the } 18 \text { of October at two in the afternoon, (the } \\
\text { shaking) was very violent. } \\
\text { (Scherer, 1912a): The earth shook violently. }\end{array}$ & $\begin{array}{l}\mathrm{CHF}(5) \\
\text { WHB(5) } \\
\operatorname{SISF}(7)\end{array}$ \\
\hline-72.2006 & 19.7616 & Cap Haitien & $\begin{array}{l}\text { (Gentleman's Magazine, 1753): } * * * \text { but on the 18th was a terrible shock: At } \\
\text { two in the afternoon of that day the earth shook twice (with a very short } \\
\text { interval) for at least three minutes each time. These shocks were so violent } \\
\text { that all were frightened and quitted their houses. At } 5 \text { in the evening we } \\
\text { were alarmed by another shock, which made us fearful of passing the night } \\
\text { in bed. }\end{array}$ & $\begin{array}{l}\text { CHF(4) } \\
\text { WHB(4) } \\
\text { SISF(6) }\end{array}$ \\
\hline
\end{tabular}




\begin{tabular}{|l|l|l|l|}
\hline October 18, 1751 & & (Moreau de St. Méry, 1798): They have felt strongly, though without injury. & \\
\hline & & & \\
\hline
\end{tabular}

\begin{tabular}{|c|c|c|c|c|}
\hline \multicolumn{5}{|c|}{ October 28, 1751} \\
\hline \multicolumn{5}{|c|}{$\begin{array}{l}\text { Time: Various times during the day. } \\
\text { Phenomenon Notes: Several aftershocks felt on this day. } \\
\text { Number of Observations: } 3\end{array}$} \\
\hline Longitude & Latitude & City & Description & Intensity \\
\hline-69.8877 & 18.4722 & Santo Domingo & $\begin{array}{l}\text { (Sevilla Soler, 1980, quoting Luís Josep Pequero, transcribed in 1762, published in } \\
\text { 1975): } * * \text { and the earthquakes continued until the } 28 \text { of the same month. [ } \\
\text { October] } \\
\text { (Moreau de St. Méry, 1798): On the 28, they experienced } 3 \text { tremors. } \\
\text { (de Utrera, 1995): Earthquake. }\end{array}$ & - \\
\hline-72.3400 & 18.5400 & Port-au-Prince & (Tippenhauer, 1893): At 8 in the evening 3 strong shocks. & - \\
\hline-72.2273 & 18.5758 & Croix de Bouquets & (Tippenhauer, 1893): At 2:30 in the morning. & - \\
\hline- & - & French side of island & $\begin{array}{l}\text { (de Mairan, 1756): There were others frequent but barely felt until the } 31 \text { and } \\
\text { the earth continued to have strong movement, though not marked tremors } \\
\text { until [Nov] } 21 \text {. }\end{array}$ & - \\
\hline
\end{tabular}

\section{October 29, 1751}

Time: One shock at 8:00 PM Cap Haitien local time, other time unknown

Phenomenon Notes: more aftershocks

Number of Observations: 3

\begin{tabular}{|l|l|l|l|l|}
\hline Longitude & Latitude & City & Description \\
\hline-69.8877 & 18.4722 & Santo Domingo & $\begin{array}{l}\text { (Moreau de St. Méry, 1798): On the 29, 2 (tremors were experienced). } \\
\text { (Tippenhauer, 1893): Two strong shocks. } \\
\text { (de Utrera, 1995): Earthquake. }\end{array}$ \\
\hline-72.3400 & 18.5400 & Port-au-Prince & (Tippenhauer, 1893): Two strong shocks. \\
\hline-72.2006 & 19.7616 & Cap Haitien & $\begin{array}{l}\text { (Gentleman's Magazine, 1753): On October 29, at 8 in the evening, was } \\
\text { another shock. }\end{array}$ \\
\hline
\end{tabular}

November 1, 1751 


\begin{tabular}{l}
\begin{tabular}{|l|l|l|l|}
\hline \multicolumn{2}{|l|}{ November 1, 1751 } \\
\hline $\begin{array}{l}\text { Time: Unknown } \\
\text { Phenomenon Notes: None } \\
\text { Number of Observations: } 1\end{array}$ \\
\hline Longitude & Latitude & City & Description \\
\hline-69.8877 & 18.4722 & Santo Domingo & (Tippenhauer, 1893): Tremor. \\
& & & - \\
(de Utrera, 1995): Frequent tremors from the 1 to the 22 of November.
\end{tabular} \\
\hline
\end{tabular}

\begin{tabular}{|c|c|c|c|c|}
\hline \multicolumn{5}{|c|}{ November 19, 1751} \\
\hline \multicolumn{5}{|c|}{$\begin{array}{l}\text { Time: } 3: 20 \text { PM, Cape Haitien local time } \\
\text { Phenomenon Notes: Possible foreshock for the earthquakes of November } 21 \text { and } 22 . \\
\text { Number of Observations: } 5\end{array}$} \\
\hline Longitude & Latitude & City & Description & Intensity \\
\hline-69.8877 & 18.4722 & Santo Domingo & $\begin{array}{l}\text { (Sevilla Soler, 1980, quoting letter written by Francisco Rubio y Peñaranda Dec. 30, } \\
\text { 1751, Archivo General de Indias, Santo Domingo, ref\# 942): Then came the } 19 \\
\text { and } 21 \text { of November in which they [earthquakes] returned with intensity } \\
\text { especially on this last day. } \\
\text { (Moreau de St. Méry, 1798): [...] and on the } 19 \text { of November, experienced } \\
\text { two more strong [earthquakes]. } \\
\text { (de Utrera, 1995): Frequent tremors from the } 1 \text { to the } 22 \text { of November; } \\
\text { violent on those of the } 19 \text { of November all over the island. }\end{array}$ & - \\
\hline-72.0107 & 19.1453 & Hinche & $\begin{array}{l}\text { (Sevilla Soler, 1980, quoting letter written by Francisco Rubio y Peñaranda Dec. } 30 \text {, } \\
\text { 1751, Archivo General de Indias, Santo Domingo, ref\# 942): Of the other } \\
\text { populations or places on the southern part of the island, the earthquakes } \\
\text { have been felt in the before mentioned days and times [18 Oct, } 19 \text { \& } 21 \text { Nov.] } \\
\text { in the villages of Hinche, Banica, and Azua, and the first location with such } \\
\text { violence that all the maize crops and large trees in the field were detached } \\
\text { from the ground by the roots *** their church had fallen to the ground it } \\
\text { being built of stone. }\end{array}$ & - \\
\hline-71.7074 & 19.0793 & Banica & $\begin{array}{l}\text { (Sevilla Soler, 1980, quoting letter written by Francisco Rubio y Peñaranda Dec. } 30, \\
\text { 1751, Archivo General de Indias, Santo Domingo, ref\# 942): Of the other } \\
\text { populations or places on the southern part of the island, the earthquakes } \\
\text { have been felt in the before mentioned days and times [18 Oct, } 19 \& 21 \text { Nov.] } \\
\text { in the villages of Hinche, Banica, and Azua } * * * \text { In Banica we have also } \\
\text { received similar news, put since they are such a poor village and infertile, } \\
\text { they have only been companions in experiencing fear. }\end{array}$ & - \\
\hline
\end{tabular}




\begin{tabular}{|c|c|c|c|c|}
\hline \multicolumn{5}{|c|}{ November 19, 1751} \\
\hline-72.3400 & 18.5400 & Port-au-Prince & (Tippenhauer, 1893): 2 strong shocks. & - \\
\hline-72.2006 & 19.7616 & Cap Haitien & $\begin{array}{l}\text { (Gentleman's Magazine, 1753): } * * * \text { on Nov. 19, at } 20 \text { minutes past } 3 \text { in the } \\
\text { afternoon was another shock which was violent but of short duration. }\end{array}$ & - \\
\hline
\end{tabular}

\begin{tabular}{|c|c|c|c|c|}
\hline \multicolumn{5}{|c|}{ November 21, 1751} \\
\hline \multicolumn{5}{|c|}{$\begin{array}{l}\text { Time: About 8:00 in the morning Port-au-Prince local time } \\
\text { Land Surface Effects: Crevasses, Sulfur (?) smelling springs and sections of mountains collapsed in the Cul-de-Sac area. Rivers in this area were noted to have } \\
\text { had their flows altered as a result. } \\
\text { Aftershocks: Aftershocks were felt that same day in Cap Haitien at 10:00 AM and 5:00 PM. } \\
\text { Phenomenon Notes: Almost completely destroyed the town of Port-au-Prince. In some locations, a noise similar to a cannon being fired accompanied this event } \\
\text { and its subsequent aftershocks. } \\
\text { Number of Observations: } 14\end{array}$} \\
\hline Longitude & Latitude & City & Description & Intensity \\
\hline-72.3400 & 18.5400 & Port-au-Prince & $\begin{array}{l}\text { (Gentleman's Magazine, 1752): Nov 21, about } 8 \text { in the morning, during a } \\
\text { profound calm, was felt a slight shock which increased to such violence that } \\
\text { almost all the stone houses at Princes Port were thrown down, and the } \\
\text { timber houses stood but little longer. } \\
\text { (de Mairan, 1756): The city of Port-au-Prince was totally destroyed too } \\
\text { except for } 19 \text { houses and all the homes in the country-side in the } \\
\text { neighborhoods we have mentioned were almost completely thrown down. } \\
\text { (Moreau de St. Méry, 1798): A light shaking *** more violent shaking } \\
\text { followed, only one of the brickwork houses did not topple. Some wooden } \\
\text { ones fell. The barracks, the general store, and a wing of the quartermaster's } \\
\text { (army supply area) fell down ** } * \text { it destroyed three quarters of the } \\
\text { buildings ** all the motion contained itself in an East to West direction. } \\
\text { (Tippenhauer, 1893): At 7:50 in the morning, } 8 \text { in the morning and } 10 \text { in the } \\
\text { morning, so strong that houses fell. } \\
\text { (Scherer, 1912a): Of one hundred houses three quarters were constructed of } \\
\text { masonry. Buildings of all sorts of construction, even the strongest, were } \\
\text { overthrown. One remained standing. A noise like that of a cannon } \\
\text { underneath the ground seemed to forewarn fresh disturbances. }\end{array}$ & \begin{tabular}{|l|} 
CHF(9) \\
WHB(9) \\
SISF(8) \\
S\&L1992(10) \\
T\&R1977(10)
\end{tabular} \\
\hline-72.2808 & 18.6042 & Cul-de-Sac & $\begin{array}{l}\text { (Gentleman's Magazine, 1752): } * * * \text { in the plain called Cul de Sac, sugar } \\
\text { mills and refining houses were thrown down, apertures were made in the }\end{array}$ & $\begin{array}{l}\text { CHF(8) } \\
\text { WHB(8) } \\
\text { SISF(8) }\end{array}$ \\
\hline
\end{tabular}




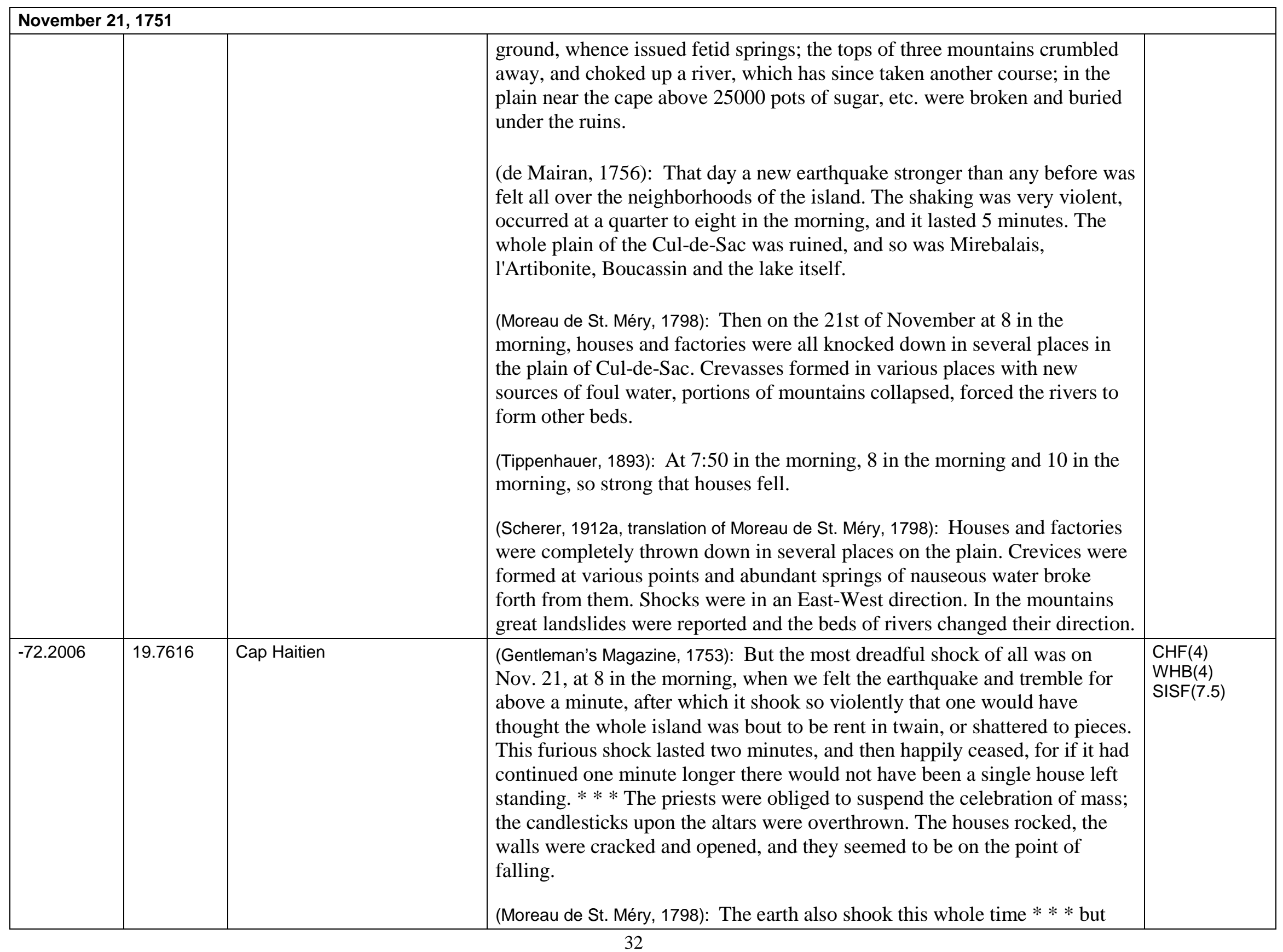




\begin{tabular}{|c|c|c|c|c|}
\hline \multicolumn{5}{|c|}{ November 21, 1751} \\
\hline & & & $\begin{array}{l}\text { not a single house fell } * * * \text { nevertheless, some people rushed out in fright, } \\
\text { jumping out first-floor windows into the streets. }\end{array}$ & \\
\hline-72.6334 & 18.5111 & Leogane & $\begin{array}{l}\text { (de Mairan, 1756): Leogane and the rest of the Cap [Cap Haitien] were less } \\
\text { mistreated. } \\
\text { (Moreau de St. Méry, 1798): Things passed more quietly; three stores were } \\
\text { badly damaged and the church also suffered } * * * \text { the city of Leogane had } \\
\text { suffered the earthquake of 1751; it lost administration, council, and royal } \\
\text { offices as well as much of its luster. } \\
\text { (Tippenhauer, 1893): At 7:50 in the morning, } 8 \text { in the morning and } 10 \text { in the } \\
\text { morning, so strong that houses fell. }\end{array}$ & $\begin{array}{l}\text { CHF(6) } \\
\text { WHB(6) } \\
\text { SISF(7.5) }\end{array}$ \\
\hline-72.6929 & 19.4458 & Gonaives & $\begin{array}{l}\text { (Moreau de St. Méry, 1798): The ravages of the quakes were so angry [strong] } \\
\text { that they were felt from Leogane to Gonaives, the movements East to West. } \\
\text { (Scherer, 1912a): Same shock felt, without causing damage. }\end{array}$ & $\begin{array}{l}\mathrm{CHF}(4) \\
\operatorname{WHB}(4)\end{array}$ \\
\hline-71.8333 & 19.6667 & $\begin{array}{l}\text { Fort Dauphin } \\
\text { (Fort Liberte) }\end{array}$ & $\begin{array}{l}\text { (Gentleman's Magazine, } 1752): * * * \text { in the district of Fort Dauphin many } \\
\text { sugar works and dwelling houses were destroyed. The consternation of the } \\
\text { people is inexpressible, most of the inhabitants of the towns pass the night } \\
\text { in the fields, the value of plantations is falling away, and everybody talks of } \\
\text { returning to France. }\end{array}$ & $\begin{array}{l}\text { CHF(5.5) } \\
\text { WHB(6) } \\
\text { SISF(7.5) }\end{array}$ \\
\hline-72.7000 & 19.1167 & Saint Marc & $\begin{array}{l}\text { (Moreau de St. Méry, 1798): The earthquake of November 21, } 1751 \text { a few } \\
\text { walls cracked in Saint-Marc. } \\
\text { (Tippenhauer, 1893): At 7:50 in the morning, } 8 \text { in the morning and } 10 \text { in the } \\
\text { morning, so strong that houses fell. }\end{array}$ & $\begin{array}{l}\text { CHF(5) } \\
\text { WHB(5) } \\
\text { SISF(7) }\end{array}$ \\
\hline-72.4500 & 18.7167 & Boucassin & $\begin{array}{l}\text { (de Mairan, 1756): } * * * \text { the whole plain of the Cul-de-Sac was ruined as so } \\
\text { was Mirebalais, l'Artibonite, Boucassin and the lake itself. }\end{array}$ & $\begin{array}{l}\text { CHF(6) } \\
\text { WHB(7) } \\
\text { SISF(8) } \\
\end{array}$ \\
\hline
\end{tabular}




\begin{tabular}{|c|c|c|c|c|}
\hline \multicolumn{5}{|c|}{ November 21, 1751} \\
\hline & & & & SISF(8) \\
\hline-72.0170 & 19.1453 & Hinche & $\begin{array}{l}\text { (Sevilla Soler, 1980, quoting letter written by Francisco Rubio y Peñaranda Dec. } 30 \text {, } \\
1751, \text { Archivo General de Indias, Santo Domingo, ref\# 942): Of the other } \\
\text { populations or places on the southern part of the island, the earthquakes } \\
\text { have been felt in the before mentioned days and times [18 Oct, } 19 \text { \& } 21 \text { Nov.] } \\
\text { in the villages of Hinche, Banica, and Azua, and the first location with such } \\
\text { violence that all the maize crops and large trees in the field were detached } \\
\text { from the ground by the roots *** their church had fallen to the ground it } \\
\text { being built of stone. }\end{array}$ & $\begin{array}{l}\text { CHF(4) } \\
\operatorname{WHB}(4)\end{array}$ \\
\hline-71.7074 & 19.0793 & Banica & $\begin{array}{l}\text { (Sevilla Soler, 1980, quoting letter written by Francisco Rubio y Peñaranda Dec. 30, } \\
\text { 1751, Archivo General de Indias, Santo Domingo, ref\# 942): Of the other } \\
\text { populations or places on the southern part of the island, the earthquakes } \\
\text { have been felt in the before mentioned days and times [18 Oct, } 19 \text { \& } 21 \text { Nov.] } \\
\text { in the villages of Hinche, Banica, and Azua *** In Banica we have also } \\
\text { received similar news, put since they are such a poor village and infertile, } \\
\text { they have only been companions in experiencing fear. }\end{array}$ & $\begin{array}{l}\mathrm{CHF}(4) \\
\operatorname{WHB}(4)\end{array}$ \\
\hline
\end{tabular}




\begin{tabular}{|c|c|c|c|c|}
\hline \multicolumn{5}{|c|}{ November 22, 1751} \\
\hline \multicolumn{5}{|c|}{$\begin{array}{l}\text { Time: Various; 4:00 AM, 6:00 AM, 3:00 PM, 4:00 PM, 8:00 PM, and 11:00 PM Cap Haitien local time } \\
\text { Phenomenon Notes: The largest aftershock felt in Port-au-Prince also accompanied by cannon-like sounds. } \\
\text { Number of Observations: } 4\end{array}$} \\
\hline Longitude & Latitude & City & Description & Intensity \\
\hline-72.3400 & 18.5400 & Port-au-Prince & $\begin{array}{l}\text { (Moreau de St. Méry, } 1798 \text { ): } * * * \text { on the } 22 \text {, the structures that survived were } \\
\text { destroyed and from the } 19 \text { to the } 22 \text { the earth was not stable for a moment. } \\
\text { Night and day a noise like a cannon announced new underground agitations. } \\
\text { From } 22 \text { [Nov.] to } 8 \text { December, there were } 25 \text { shocks } * * * \text { the shocks were } \\
\text { significant from Leogane to Gonaives. } \\
\text { (Tippenhauer, 1893): At } 4 \text { to } 6 \text { in the early morning and at } 3 \text { to } 11 \text { in the } \\
\text { afternoon and evening, direction east to west. }\end{array}$ & - \\
\hline-72.6334 & 18.5111 & Leogane & $\begin{array}{l}\text { (Moreau de St. Méry, 1798): From } 22 \text { to } 8 \text { December, there were } 25 \text { shocks * } \\
* * \text { the shocks were significant from Leogane to Gonaives. }\end{array}$ & - \\
\hline-72.6929 & 19.4458 & Gonaives & $\begin{array}{l}\text { (Moreau de St. Méry, 1798): From } 22 \text { to } 8 \text { December, there were } 25 \text { shocks * } \\
* * \text { the shocks were significant from Leogane to Gonaives. }\end{array}$ & - \\
\hline-72.2006 & 19.7616 & Cap Haitien & $\begin{array}{l}\text { (Gentleman's Magazine, } 1753 \text { ): Nov. 22, } 1751 \text { At } 4 \text { and } 6 \text { A.M. at 3, 4, 8, and } \\
11 \text { P.M. - The shock at } 3 \text { o'clock this day was as violent as that of October } \\
18 .\end{array}$ & - \\
\hline-69.8877 & 18.4722 & Santo Domingo & $\begin{array}{l}\text { (de Utrera, 1995): On the } 22 \text { of November felt all over the island with } \\
\text { destruction on the western side. }\end{array}$ & - \\
\hline
\end{tabular}

\begin{tabular}{|c|c|c|c|c|}
\hline \multicolumn{5}{|c|}{ November 23,1751 to November 30,1751} \\
\hline Longitude & Latitude & City & Description & Intensity \\
\hline-72.6334 & 18.5111 & Leogane & (Moreau de St. Méry, 1798): From 22 to 8 December, there were 25 shocks * & - \\
\hline
\end{tabular}




\begin{tabular}{|c|c|c|c|c|}
\hline \multicolumn{5}{|c|}{ November 23,1751 to November 30,1751} \\
\hline & & & $\begin{array}{l}* * \text { the shocks were significant from Leogane to Gonaives. } \\
\text { (Tippenhauer, 1893): } 25 \text { shocks were felt in total from November } 23 \text { to } \\
\text { December 5, East to West in direction; November } 28 \text { - at 8:45 in the } \\
\text { morning, in east to west direction, shock felt; November } 30 \text { - shock felt, in } \\
\text { east to west direction. }\end{array}$ & \\
\hline-72.6929 & 19.4458 & Gonaives & $\begin{array}{l}\text { (Moreau de St. Méry, 1798): From } 22 \text { to } 8 \text { December, there were } 25 \text { shocks * } \\
* * \text { the shocks were significant from Leogane to Gonaives. } \\
\text { (Tippenhauer, 1893): } 25 \text { shocks were felt in total from November } 23 \text { to } \\
\text { December 5, East to West in direction; November } 28 \text { - at 8:45 in the } \\
\text { morning, in east to west direction, shock felt; November } 30 \text { - shock felt, in } \\
\text { east to west direction. }\end{array}$ & \\
\hline-72.2006 & 19.7616 & Cap Haitien & 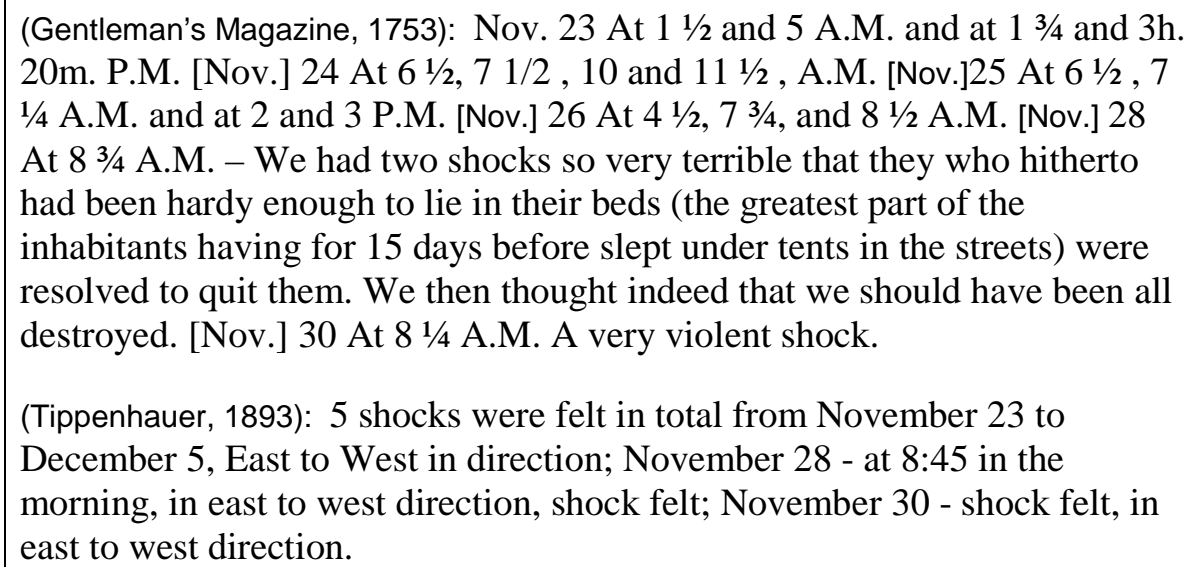 & \\
\hline
\end{tabular}

\section{December 1, 1751 to January, 1752}

\section{Time: Various times}

Phenomenon Notes: Aftershocks felt in the month of December and into January of 1752 . The account written by de Langrene living in Cap Haitien (then Cap Francois) dated December 16, 1751 and published in the July 1753 issue of The Gentleman's Magazine and has additional descriptions of damage from the 1751 earthquakes but he does not attribute an exact date to when they happened. Some of de Langrene's descriptions include: In the isle of Cows [Ile a Vache (-73.64, 18.07), southeast of Les Cayes ] the cottages are all so shattered that they must be rebuilt *** A village upon the sea coast two leagues from St.

Domingo, the Spanish capital, was entirely swallowed up, but so gradually that the inhabitants had time to remove their effects, sloops and canoes at present sail over the place where this village stood $* * *$ Near Banie [Bani] a volcano broke out and threw out fire, smoke, water, and stones, but it hath disappeared, and where it was there is now a salt water lake, the bottom whereof cannot be found $* * *$ The ships that arrived about the time of the great shocks, felt them at 100 leagues distance from the island. The sailors perceived such an agitation in the sea as made them imagine that the 


\begin{tabular}{|c|c|c|c|c|}
\hline \multicolumn{5}{|c|}{ December 1, 1751 to January, 1752} \\
\hline \multicolumn{5}{|c|}{$\begin{array}{l}\text { vessel was foundering or that she struck. All the vessels at anchor in our road [Cap Haitien] were very much tossed and agitated, and everything in } \\
\text { their holds overturned. } \\
\text { Number of Observations: } 5\end{array}$} \\
\hline Longitude & Latitude & City & Description & Intensity \\
\hline-72.3400 & 18.5400 & Port-au-Prince & $\begin{array}{l}\text { (Moreau de St. Méry, 1798): From } 22 \text { to } 8 \text { December, there were } 25 \text { shocks. } \\
\text { (Tippenhauer, 1893): December } 1 \text { - at } 7 \text { in the morning, shock felt, in east to } \\
\text { west direction; December } 5 \text { - at } 2 \text { in the morning, shock felt, in east to west } \\
\text { direction; December } 8,1751 \text { - shock; January } 1752 \text { - shock. }\end{array}$ & - \\
\hline-72.6334 & 18.5111 & Leogane & $\begin{array}{l}\text { (Tippenhauer, 1893): December } 1 \text { - at } 7 \text { in the morning, shock felt, in east to } \\
\text { west direction; December } 5 \text { - at } 2 \text { in the morning, shock felt, in east to west } \\
\text { direction. }\end{array}$ & - \\
\hline-72.6929 & 19.4458 & Gonaives & $\begin{array}{l}\text { (Tippenhauer, 1893): December } 1 \text { - at } 7 \text { in the morning, shock felt, in east to } \\
\text { west direction; December } 5 \text { - at } 2 \text { in the morning, shock felt, in east to west } \\
\text { direction. }\end{array}$ & - \\
\hline-72.2006 & 19.7616 & Cap Haitien & $\begin{array}{l}\text { (Gentleman's Magazine, 1753): Dec 1. At } 7 \text { P.M. A quick strong tremor. [Dec.] } \\
5 \text { At } 2 \text { A.M. [Dec.] } 12 \text { At } 7 \text { 1/2 A.M. A slight shock. } \\
\text { (Tippenhauer, 1893): December } 1 \text { - at } 7 \text { in the morning, shock felt, in east to } \\
\text { west direction; December } 5 \text { - at } 2 \text { in the morning, shock felt, in east to west } \\
\text { direction. }\end{array}$ & - \\
\hline-69.8877 & 18.4722 & Santo Domingo & (Tippenhauer, 1893): December 12, 1751 at 7:30 in the morning, shock. & - \\
\hline
\end{tabular}

\begin{tabular}{|c|c|c|c|c|}
\hline \multicolumn{5}{|c|}{ 1753, 1754 and Nov (?) 1755} \\
\hline \multicolumn{5}{|c|}{$\begin{array}{l}\text { Time: Unknown } \\
\text { Phenomenon Notes: Tippenhauer (1893) notes a November (?) for the } 1755 \text { earthquake. } \\
\text { Number of Observations: } 1\end{array}$} \\
\hline Longitude & Latitude & City & Description & Intensity \\
\hline
\end{tabular}




\begin{tabular}{|c|c|c|c|c|}
\hline \multicolumn{5}{|c|}{ March 8, 1764} \\
\hline \multicolumn{5}{|c|}{$\begin{array}{l}\text { Time: } 10: 55 \text { in the evening, Saint Marc local time } \\
\text { Phenomenon Notes: None } \\
\text { Number of Observations: } 1\end{array}$} \\
\hline Longitude & Latitude & City & Description & Intensity \\
\hline-72.7000 & 19.1167 & Saint Marc & $\begin{array}{l}\text { (Moreau de St. Méry, 1798): On March 8, 1764, we felt there, at 10:55 in the } \\
\text { evening, two shocks from earthquakes that each lasted } 15 \text { seconds. } \\
\text { (Tippenhauer, 1893): At } 10 \text { hrs } 55 \text { minutes in the evening, lasting } 15 \text { seconds, } \\
2 \text { shocks. }\end{array}$ & - \\
\hline
\end{tabular}

\begin{tabular}{|l|l|l|l|l|}
\hline \multicolumn{5}{|l|}{ September $\mathbf{1 7 6 5}$} \\
\hline $\begin{array}{l}\text { Time: Unknown } \\
\text { Phenomenon Notes: None } \\
\text { Number of Observations: } 2\end{array}$ & Description & Intensity \\
\hline Longitude & Latitude & City & $\begin{array}{l}\text { (Moreau de St. Méry, 1798): At the beginning of September 1765, there were } \\
\text { several shocks of an earthquake. } \\
\text { (Tippenhauer, 1893): Earthquake. }\end{array}$ & - \\
\hline-72.7709 & 18.4256 & Grand Goave & (Moreau de St. Méry, 1798): *** in 1765 the earth shook five times. & - \\
\hline-72.6334 & 18.5111 & Leogane &
\end{tabular}

\section{January 27,1766}

Time: $6: 30$ in the evening, Cap Haitien local time

Phenomenon Notes: None

Number of Observations: 1

\begin{tabular}{|l|l|l|l|l|}
\hline Longitude & Latitude & City & Description & Intensity \\
\hline-72.2006 & 19.7616 & Cap Haitien & $\begin{array}{l}\text { (Moreau de St. Méry, 1798): The earth shook on 27 January, 1766, at half past } \\
\text { 6 o'clock in the evening, and the shaking was quite strong. } \\
\text { (Tippenhauer, 1893): At 6:30, quite strong. }\end{array}$ \\
\hline
\end{tabular}

\section{January 30, 1766}

Time: Unknown

Phenomenon Notes: None

Number of Observations: 1

\begin{tabular}{|l|l|l|}
\hline Longitude & Latitude & City
\end{tabular} 


\begin{tabular}{|l|l|l|l|l|}
\hline- & - & Spanish half of island & $\begin{array}{l}\text { (Perrey, 1857): Spanish part. } \\
\text { (Tippenhauer, 1893): January 30, Spanish part. } \\
\text { (de Utrera, 1995): January 30, eastern part. }\end{array}$ \\
\hline
\end{tabular}

\begin{tabular}{|c|c|c|c|c|}
\hline April 26, 17 & & & & \\
\hline $\begin{array}{l}\text { Time: Few } \\
\text { Phenomen } \\
\text { Number of }\end{array}$ & $\begin{array}{l}\text { inutes afte } \\
\text { Notes: } \\
\text { bservation }\end{array}$ & $\begin{array}{l}00 \text { in the ever } \\
e_{1}\end{array}$ & al time & \\
\hline Longitude & Latitude & City & Description & Intensity \\
\hline
\end{tabular}

\section{December 27, 1767}

Time: $4: 30$ in the morning, Port-au-Prince local time

Phenomenon Notes: None

Number of Observations: 1

\begin{tabular}{|c|c|c|c|c|}
\hline Longitude & Latitude & City & Description & Intensity \\
\hline-72.3400 & 18.5400 & Port-au-Prince & $\begin{array}{l}\text { (Moreau de St. Méry, 1798): The land was quiet until December } 27,1767 \text {; the } \\
\text { earth trembled very much at half past four in the morning but without } \\
\text { causing any damage. } \\
\text { (Moreau de Jonnes, 1822): In Santo Domingo island. } \\
\text { (Tippenhauer, 1893): December 27, } 4: 30 \text { early, Port-au-Prince, light shock } \\
\text { without damage. }\end{array}$ & - \\
\hline
\end{tabular}

\section{January 21, 1768}

Time: $6: 30$ in the evening, Cap Haitien local time

Phenomenon Notes: None

Number of Observations: 1

\begin{tabular}{|l|l|l|l|l|}
\hline Longitude & Latitude & City & Description \\
\hline-72.2006 & 19.7616 & Cap Haitien & (Moreau de Jonnes, 1822): 20 January. [on the island] \\
& & & (Perrey, 1843): 21 of January, 6:30 in the evening, in Cap Français, a slight
\end{tabular}




\begin{tabular}{|l|l|l|l|}
\hline January 21, 1768 & & $\begin{array}{l}\text { shaking from West to East. } \\
\text { (Tippenhauer, 1893): January 21, 6:30 early, West to East, Cap Haitien. }\end{array}$ \\
\hline
\end{tabular}

\section{October 4, 1768}

Time: Evening

Phenomenon Notes: None

Number of Observations: 1

\begin{tabular}{|l|l|l|l|l|}
\hline Longitude & Latitude & City & Description \\
\hline-72.8668 & 18.4315 & Petit Goave & $\begin{array}{l}\text { (Moreau de St. Méry, 1798): On October 4, 1768 in the evening, there were } \\
\text { two strong shocks from earthquakes. }\end{array}$ \\
(Tippenhauer, 1893): October 4, evening, Petit Goave.
\end{tabular}

\section{October 10, 1768}

Time: Unknown

Phenomenon Notes: None

Number of Observations: 1

\begin{tabular}{|l|l|l|l|l|}
\hline Longitude & Latitude & City & Description \\
\hline-72.3400 & 18.5400 & Port-au-Prince & (Moreau de St. Méry, 1798): On October 10, 1768, there were three shocks. \\
(Moreau de Jonnes, 1822): 10 October. [on the island] \\
(Tippenhauer, 1893): October 10, Port-au-Prince, 3 shocks.
\end{tabular}

\section{August 14, 1769}

Time: Unknown

Phenomenon Notes: None

Number of Observations: 1

\begin{tabular}{|l|l|l|l|l|}
\hline Longitude & Latitude & City & Description & Intensity \\
\hline-72.3400 & 18.5400 & Port-au-Prince & (Moreau de St. Méry, 1798): *** and one [earthquake] on August 14, 1769. \\
& & (Tippenhauer, 1893): August 14, Port-au-Prince, 1 shock. \\
\hline
\end{tabular}

\section{January 20, 1770 and April 12, 1770}




\begin{tabular}{|c|c|c|c|c|}
\hline \multicolumn{5}{|c|}{ January 20, 1770 and April 12, 1770} \\
\hline \multicolumn{5}{|c|}{$\begin{array}{l}\text { Time: Unknown } \\
\text { Phenomenon Notes: possible foreshocks? } \\
\text { Number of Observations: } 1\end{array}$} \\
\hline Longitude & Latitude & City & Description & Intensity \\
\hline-72.3400 & 18.5400 & Port-au-Prince & $\begin{array}{l}\text { (Moreau de St. Méry, 1798): The earth shook on January } 20 \text { and on April 12, } \\
1770 . \\
\text { (Moreau de Jonnes, 1822): April 12, in Santo Domingo [island]. } \\
\text { (Tippenhauer, 1893): January 20, Port-au-Prince, soft shaking of the ground; } \\
\text { April 12. }\end{array}$ & - \\
\hline
\end{tabular}

\section{June 3, 1770}

Time: About 7:30 in the evening, Port-au-Prince local time (Pentecost - Christian holiday)

Land Surface Observations: Crevasses formed around Enriquillo and Laguna lakes, landslides occurred somewhere on the Grand Riviere near Leogane blocking river flow for several hours. Springs appeared in the Artibonite region. Liquefaction effects were observed in the Croix-de-Bouquets area.

Tsunami: The sea flowed in about a league and a half up into the land (Gentleman's Magazine, 1770b). Another account from Port-au-Prince describes: the sea rose twenty feet high by a tidal wave and it came ravaging into the land $1 / 4$ of a league. (Hippeau, 1864)

Aftershocks: For a period of a month after the main earthquake, aftershocks were felt on the island.

Phenomenon Notes: According to the historian Garcia (1900), in $1770 * * *$ an earthquake, like no other ever was felt in the Antilles, which was felt from one extreme part of the island to the other on June 3, and as a consequence the whole population in general experienced either great or little damage.

Potentially the major towns on the Spanish side of the island felt this earthquake as suggested in The Gentleman's Magazine (1770b): This earthquake was more severely felt at St. Domingo, where the whole island was agitated; and in the Annual Register (1771b): Letters from St. Domingo confirm the melancholy account, of the calamity which happened there on the $3 \mathrm{~d}$ of last month. It is said the earthquake extended thirty-five leagues.

Number of Observations: 34

\begin{tabular}{|c|c|c|c|c|}
\hline Longitude & Latitude & City & Description & Intensity \\
\hline-72.3400 & 18.5400 & Port-au-Prince & $\begin{array}{l}\text { (Moreau de St. Méry, 1798): It was June 3, of the same year [1770], day of the } \\
\text { Pentecost. At a quarter after } 7 \text { in the evening the entire island was hit by an } \\
\text { earthquake that was preceded by a noise that sounded like a roar. The first } \\
\text { two shocks, felt in Port-au-Prince were followed very closely together } \\
\text { lasted less than four minutes and during this succession of undulating } \\
\text { motion from East to West pulsation, the entire city was thrown down; the } \\
\text { gun-powder room alone resisted and opened a little. *** It was said that } \\
\text { the earth boiled and that it became liquid, for this movement resembled that } \\
\text { of the waves of the ocean. The earth was open in thousand places *** } \\
\text { soldiers were buried under the ruins of the barracks and hospitals, and }\end{array}$ & $\begin{array}{l}\text { CHF(9) } \\
\text { WHB(9) } \\
\text { SISF(8) } \\
\text { S\&L1992(10) } \\
\text { T\&R1977(10) }\end{array}$ \\
\hline
\end{tabular}




\begin{tabular}{|c|c|c|c|c|}
\hline \multicolumn{5}{|c|}{ June $\mathbf{3}, 1770$} \\
\hline & & & $\begin{array}{l}\text { prisoners were crushed by the debris of the jail. The public edifices, such as } \\
\text { the Government building, the Intendancy, the Council building, and most } \\
\text { solid structures, like the new church } * * * \text { the powder magazine, and private } \\
\text { houses were no more than heaps. Only the rows of trees made the streets } \\
\text { recognizable } * * \text { The earthquake toppled the council building except the } \\
\text { south wing, which was being repaired in its lower part } * * * \text { The hospital } \\
\text { was overthrown in } 1770 \text { by the earthquake. } \\
\text { (Moreau de Jonnes, 1822): June 3, at } 7 \text { o'clock in the evening, in [Hispaniola] } \\
\text { and most of the West Indies; Leogane, Petit-Goave and Port-au-Prince, } \\
\text { were destroyed, the shocks were in the East to West direction. For a month, } \\
\text { there was not a day that shocks were not felt. } \\
\text { (Southey, 1827): *** but the city of Port-au-Prince was entirely destroyed; } \\
\text { not one house was left standing and above } 500 \text { persons were buried in the } \\
\text { ruins *** The plains of Leogane, Port-au-Prince, Petit-Goave, suffered } \\
\text { considerably - all the sugar works were destroyed. } \\
\text { (Perrey, 1847): June 3, in the western part of the island of Santo Domingo, } \\
\text { earthquake. The first tremor began at 7:03 in the evening and lasted } 3 \\
\text { minutes in an East to West direction. The aftershocks have been around the } \\
\text { compass. All buildings in Port-au-Prince and other places have been thrown } \\
\text { down ** The shocks continued until June 5, almost without interruption. } \\
\text { (Scherer, 1912a): At a quarter after seven o'clock in the evening, the whole } \\
\text { island experienced an earthquake, preceded by a dull noise like rumbling, } \\
\text { and by considerable agitation directed from East to West *** being all } \\
\text { outdoors or on their porches had time at the first sound to rush into the } \\
\text { middle of the street, which were broad and bordered by elms. }\end{array}$ & \\
\hline-72.6929 & 19.4458 & Leogane & $\begin{array}{l}\text { (Moreau de St. Méry, 1798): The church, the presbytery, the Government } \\
\text { building, the powder magazine, the military hospital, fell to the ground } * * * \\
\text { the rest of the city presented only ruins } * * * \text { the plain did not suffer less } * * \\
* \text { buildings on the sugar and coffee plantations were destroyed or } \\
\text { considerably damaged. } \\
\text { (Moreau de St. Méry, 1798; Scherer, 1912a): Several springs dried up and didn't } \\
\text { flow again for ten years. Road from Leogane to Jacmel was entirely blocked }\end{array}$ & \begin{tabular}{l|} 
CHF(9) \\
WHB(-) \\
SISF(8) \\
S\&L1992(10) \\
T\&R1977(10)
\end{tabular} \\
\hline
\end{tabular}




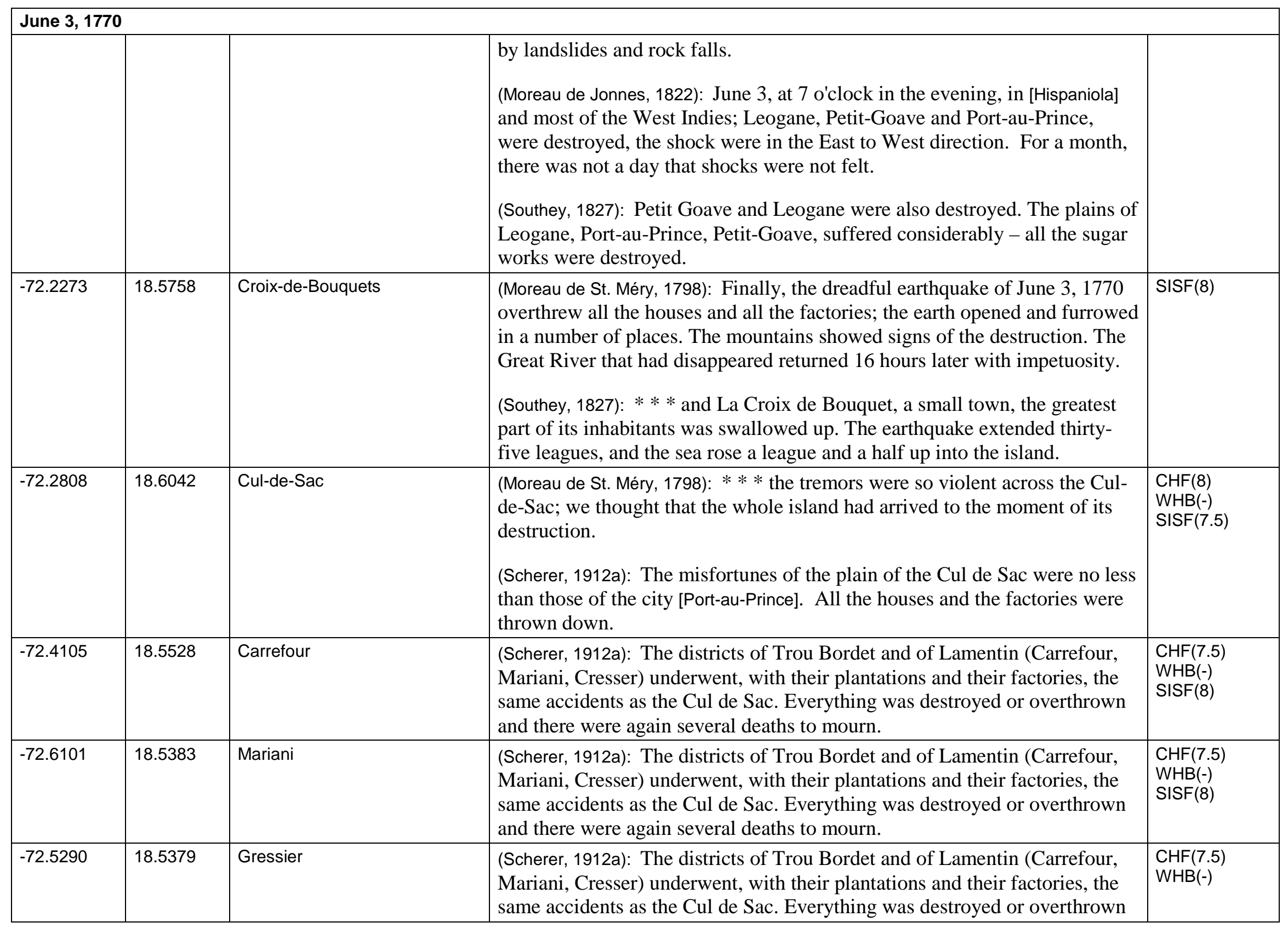




\begin{tabular}{|c|c|c|c|c|}
\hline \multicolumn{5}{|c|}{ June 3, 1770} \\
\hline & & & and there were again several deaths to mourn. & \\
\hline-72.7709 & 18.4256 & Grand Goave & $\begin{array}{l}\text { (Moreau de St. Méry, 1798): In the earthquake of 1770, the sea, as I noted } \\
\text { earlier, a portion of the land submerged at the bottom of the hill La Saline, } \\
\text { and parts of Tapion [mountain] collapsed, while other places formed sink } \\
\text { holes which interrupted the path. }\end{array}$ & - \\
\hline-72.3297 & 18.5324 & Turgeau & $\begin{array}{l}\text { (Scherer, 1912a): As for the effects on the earth itself, the spring of Turgeau } \\
\text { was diminished by half its flow and about the capital the hills even } \\
\text { subsided. }\end{array}$ & $\begin{array}{l}\mathrm{CHF}(6) \\
\text { WHB(-) }\end{array}$ \\
\hline-72.1892 & 18.4909 & Grande Riviere & $\begin{array}{l}\text { (Moreau de St. Méry, 1798): } * * * \text { ceased to flow for sixteen hours and began } \\
\text { again with a flood of water. }\end{array}$ & $\begin{array}{l}\text { CHF(6) } \\
\text { WHB(-) }\end{array}$ \\
\hline-72.5126 & 18.7701 & Arcahaie & $\begin{array}{l}\text { (Moreau de St. Méry, 1798): The earthquake of } 1751 \text {, it cracked the buildings } \\
\text { like they did in June } 3,1770 \text {, the masonry from sugar mills and the water } \\
\text { drains } * * * \text { disappeared. } \\
\text { (Scherer, 1912a): The market town of Arcahaie had only slight losses. The } \\
\text { church was badly damaged and rendered unfit for use; it only resisted, } \\
\text { thanks to the buttresses with which it was shored up. Altogether the repairs } \\
\text { cost the inhabitants more than eighty thousand francs. Fifteen sugar } \\
\text { refineries were destroyed in the plain and a house in the Canton des Vases } \\
\text { partly submerged. }\end{array}$ & $\begin{array}{l}\mathrm{CHF}(7) \\
\text { WHB(7) } \\
\text { SISF(7) }\end{array}$ \\
\hline-72.1040 & 18.8336 & Mirebalais & $\begin{array}{l}\text { (Scherer, 1912a): At Mirebalais a very fine church was slightly damaged, but } \\
\text { the curé [priest] and the inhabitants abandoned it in excessive fear and before } \\
\text { any appearance of danger. }\end{array}$ & $\begin{array}{l}\mathrm{CHF}(6) \\
\text { WHB(6) } \\
\operatorname{SISF}(7)\end{array}$ \\
\hline-72.3953 & 18.2311 & Cayes Jacmel & $\begin{array}{l}\text { (Moreau de St. Méry, 1798): The earthquake of } 1770 \text { damaged the indigo } \\
\text { plantations. }\end{array}$ & $\begin{array}{l}\operatorname{CHF}(7) \\
\operatorname{WHB}(7) \\
\operatorname{SISF}(7.5)\end{array}$ \\
\hline-72.5345 & 18.2359 & Jacmel & $\begin{array}{l}\text { (Moreau de St. Méry, 1798): The earthquake of } 1770 \text { threw down the houses } \\
\text { in the city made of masonry, while others suffered more or less, the vessels } \\
\text { storing the indigo were damaged; a lot of indigo was lost. }\end{array}$ & $\begin{array}{l}\operatorname{CHF}(7.5) \\
\operatorname{WHB}(7) \\
\operatorname{SISF}(7.5)\end{array}$ \\
\hline-73.3971 & 18.2816 & Aquin & $\begin{array}{l}\text { (Moreau de St. Méry, 1798): The earthquake of } 1770 \text { did little damage } \\
\text { although it did knock down the church. }\end{array}$ & $\begin{array}{l}\text { CHF(6.5) } \\
\text { WHB(7) } \\
\text { SISF(7) }\end{array}$ \\
\hline-73.6552 & 18.2992 & Cavaillon & $\begin{array}{l}\text { (Moreau de St. Méry, 1798): The earthquake of } 1770 \text { cracked the buildings } \\
\text { and not much was thrown down since Cavaillon is small. }\end{array}$ & $\begin{array}{l}\text { CHF(7) } \\
\text { WHB(7) } \\
\text { SISF(7) }\end{array}$ \\
\hline-73.5466 & 18.2630 & Saint Louis du Sud & (Moreau de St. Méry, 1798): The earthquake of 1770, it caused a few & $\mathrm{CHF}(7)$ \\
\hline
\end{tabular}




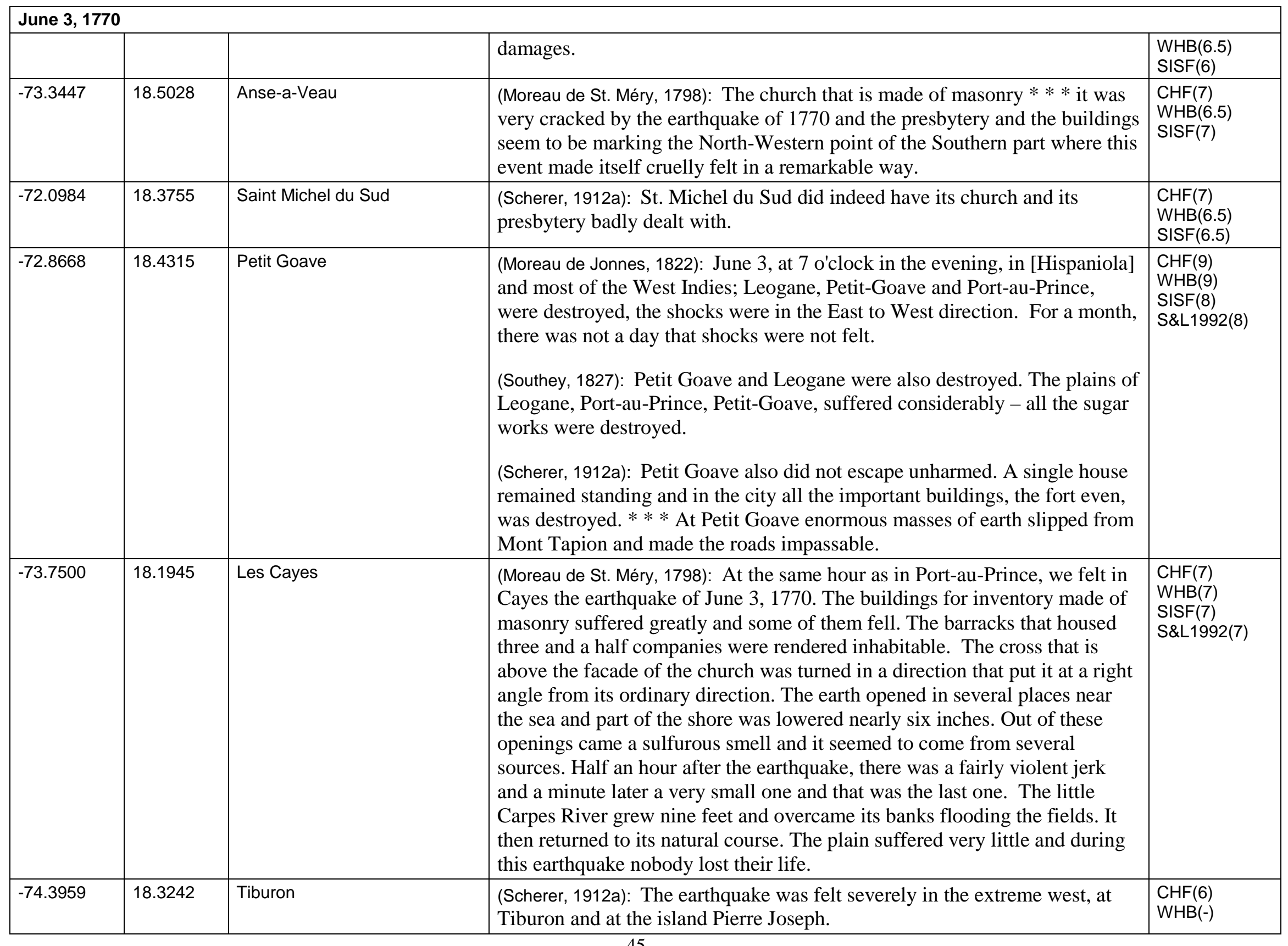




\begin{tabular}{|c|c|c|c|c|}
\hline \multicolumn{5}{|c|}{ June 3,1770} \\
\hline & & & & $\begin{array}{l}\text { S\&L1992(6) } \\
\text { T\&R1977(6) }\end{array}$ \\
\hline-74.4673 & 18.4588 & Isle Pierre Joseph & $\begin{array}{l}\text { (Scherer, 1912a): The earthquake was felt severely in the extreme west, at } \\
\text { Tiburon and at the island Pierre Joseph. }\end{array}$ & $\begin{array}{l}\mathrm{CHF}(6) \\
\mathrm{WHB}(-)\end{array}$ \\
\hline-72.6978 & 19.1081 & Saint Marc & $\begin{array}{l}\text { (Gentleman's Magazine, 1770a; Annual Register, 1771a): St. Mark's [St. Marc], } \\
\text { Port de Paix, the Cape [Cape Haitien], and Fort Dauphin [Fort Liberte], only felt } \\
\text { the shock as they did at the Mole [Mole-St.Nicolas] } \\
\text { (Scherer, 1912a): More to the north, at St. Marc, the shock was scarcely } \\
\text { perceptible. }\end{array}$ & - \\
\hline-72.6933 & 19.2464 & Plain Artibonite & $\begin{array}{l}\text { (Scherer, 1912a): The plain of the Artibonite however, sustained some hurt } \\
\text { and it was claimed that the Eaux de Boyenes (Port-au-Piment) a cold } \\
\text { mineral spring disappeared. }\end{array}$ & $\begin{array}{l}\mathrm{CHF}(6) \\
\mathrm{WHB}(-)\end{array}$ \\
\hline-72.9872 & 19.6123 & Port-au-Piment & $\begin{array}{l}\text { (Moreau de St. Méry, 1798): Earthquakes are fairly common in Eaux de } \\
\text { Boyenes, and these waters then exhale a larger amount of sulfur dioxide. It } \\
\text { is claimed that the June } 3,1770 \text { caused the disappearance of a cold water } \\
\text { spring. }\end{array}$ & $\begin{array}{l}\mathrm{CHF}(6) \\
\mathrm{WHB}(-)\end{array}$ \\
\hline-71.8370 & 19.6668 & $\begin{array}{l}\text { Fort Liberte } \\
\text { (Fort Dauphin) }\end{array}$ & $\begin{array}{l}\text { (Gentleman's Magazine, 1770a; Annual Register, 1771a): St. Mark's [St. Marc], } \\
\text { Port de Paix, the Cape [Cape Haitien], and Fort Dauphin [Fort Liberte], only felt } \\
\text { the shock as they did at the Mole [Mole-St.Nicolas] } \\
\text { (Scherer, 1912a): But this earthquake of the Southern depression behaved in } \\
\text { a much more remarkable manner from Mole St. Nicolas to Fort Liberte in } \\
\text { the Northern Depression. Houses were damaged. }\end{array}$ & $\begin{array}{l}\mathrm{CHF}(6) \\
\mathrm{WHB}(-) \\
\operatorname{SISF}(6)\end{array}$ \\
\hline-72.2006 & 19.7616 & Cap Haitien & $\begin{array}{l}\text { (Gentleman's Magazine, 1770a; Annual Register, 1771a): St. Mark's [St. Marc], } \\
\text { Port de Paix, the Cape [Cape Haitien], and Fort Dauphin [Fort Liberte], only felt } \\
\text { the shock as they did at the Mole [Mole-St.Nicolas] } \\
\text { (Moreau de St. Méry, 1798): [...] felt strongly, though without injury. }\end{array}$ & $\begin{array}{l}\mathrm{CHF}(4) \\
\mathrm{WHB}(-) \\
\operatorname{SISF}(6)\end{array}$ \\
\hline-72.8370 & 19.9408 & Port-de-Paix & $\begin{array}{l}\text { (Moreau de St. Méry, 1798): Besides the earthquake of June } 3,1770 * * * \text { we } \\
\text { felt a jolt. } \\
\text { (Scherer, 1912a): [...] and at Port de Paix for instance the facade and the } \\
\text { doorway of the church were thrown down. }\end{array}$ & $\begin{array}{l}\text { CHF(5) } \\
\text { WHB(6) } \\
\text { SISF(7) } \\
\text { S\&L1992(6) }\end{array}$ \\
\hline-73.3745 & 19.8052 & Mole-St. Nicolas & $\begin{array}{l}\text { (Gentleman's Magazine, July 1770a): An account received at the General Post } \\
\text { Office, that on Sunday the 3d of June, about } 15 \text { minutes after seven in the }\end{array}$ & $\begin{array}{l}\mathrm{CHF}(6) \\
\mathrm{WHB}(6.5)\end{array}$ \\
\hline
\end{tabular}




\begin{tabular}{|c|c|c|c|c|}
\hline \multicolumn{5}{|c|}{ June 3,1770} \\
\hline & & & $\begin{array}{l}\text { evening they felt, at Cape Nicola Mole, four violent shocks of an } \\
\text { earthquake; the most severe lasted two minutes and a half, accompanied } \\
\text { with a noise much like the echo that is heard from the hills after the firing of } \\
\text { cannon, but the town fortunately received no damage. } \\
\text { (Southey, 1827): Upon the 3rd of June, about a quarter past seven in the } \\
\text { evening, four violent shocks of an earthquake were felt at Cape Nicola } \\
\text { Mole, in St. Domingo (island): the most severe lasted two minutes and a } \\
\text { half, accompanied with a noise much like the echo from the hills after the } \\
\text { firing of a cannon. The town did not receive any damage. }\end{array}$ & $\begin{array}{l}\text { SISF(7) } \\
\text { S\&L1992(5) } \\
\text { T\&R1977(6) }\end{array}$ \\
\hline-69.8877 & 18.4744 & Santo Domingo & $\begin{array}{l}\text { (Scherer, 1912a): To the east region of the lakes was covered with cracks } \\
\text { several feet in depth and it is presumed that the plains of Neyba and of Azua } \\
\text { had again to suffer for at Santo Domingo the shock was felt vigorously but } \\
\text { without great damage it seems. } \\
\text { (Taber, 1922): It was strong at Santo Domingo City but no great damage } \\
\text { resulted. } \\
\text { (de Utrera, 1995): June } 3 \text { at 7:25 PM. Island, almost all the population } \\
\text { suffered great damage; Santo Domingo saw the repeat of the effects of May } \\
\text { 9, } 1673 \text {. }\end{array}$ & $\begin{array}{l}\text { CHF(5) } \\
\text { WHB(6) } \\
\text { S\&L1992(5) } \\
\text { C1972(8) }\end{array}$ \\
\hline-70.7291 & 18.4534 & Azua & $\begin{array}{l}\text { (Garcia, 1900): In } 1770 * * * \text { an earthquake, like no other ever felt in the } \\
\text { Antilles, which was felt from one extreme part of the island to the other on } \\
\text { June 3, and as a consequence the whole population in general experienced } \\
\text { either great or little damage. } \\
\text { (Scherer, 1912a): To the east region of the lakes was covered with cracks } \\
\text { several feet in depth and it is presumed that the plains of Neyba and of Azua } \\
\text { had again to suffer for at Santo Domingo the shock was felt vigorously but } \\
\text { without great damage it seems. }\end{array}$ & $\begin{array}{l}\mathrm{CHF}(6) \\
\mathrm{WHB}(-)\end{array}$ \\
\hline-71.4178 & 18.4832 & Neiba & $\begin{array}{l}\text { (Garcia, 1900): In } 1770 * * * \text { an earthquake, like no other ever felt in the } \\
\text { Antilles, which was felt from one extreme part of the island to the other on } \\
\text { June } 3 \text {, and as a consequence the whole population in general experienced } \\
\text { either great or little damage. } \\
\text { (Scherer, 1912a): To the east region of the lakes was covered with cracks } \\
\text { several feet in depth and it is presumed that the plains of Neyba and of Azua }\end{array}$ & - \\
\hline
\end{tabular}




\begin{tabular}{|c|c|c|c|c|}
\hline \multicolumn{5}{|c|}{ June 3,1770} \\
\hline & & & $\begin{array}{l}\text { had again to suffer for at Santo Domingo the shock was felt vigorously but } \\
\text { without great damage it seems. }\end{array}$ & \\
\hline-71.7151 & 18.4211 & $\begin{array}{l}\text { Laguna Icotea (pond south of } \\
\text { Enriquillo Lake) }\end{array}$ & $\begin{array}{l}\text { (Moreau de St. Méry, 1796): L’Etang Salé [Enriquillo Lake] and L’Etang Doux } \\
\text { [Laguna Icotea] were bordered by crevasses a few of which are up to six feet } \\
\text { deep. They are regarded as signs of earthquakes, notably that of June 3, } \\
\text { 1770. } \\
\text { (Garcia, 1900): In } 1770 * * * \text { an earthquake, like no other ever felt in the } \\
\text { Antilles, which was felt from one extreme part of the island to the other on } \\
\text { June 3, and as a consequence the whole population in general experienced } \\
\text { either great or little damage. } \\
\text { (Scherer, 1912a): To the east region of the lakes was covered with cracks } \\
\text { several feet in depth and it is presumed that the plains of Neyba and of Azua } \\
\text { had again to suffer for at Santo Domingo the shock was felt vigorously but } \\
\text { without great damage it seems. }\end{array}$ & $\begin{array}{l}\text { CHF(6) } \\
\text { WHB(-) }\end{array}$ \\
\hline
\end{tabular}




\begin{tabular}{|c|c|c|c|c|}
\hline \multicolumn{5}{|l|}{ July, 1770} \\
\hline \multicolumn{5}{|c|}{$\begin{array}{l}\text { Time: Unknown } \\
\text { Phenomenon Notes: Aftershocks of June } 3,1770 \\
\text { Number of Observations: } 1\end{array}$} \\
\hline Longitude & Latitude & City & Description & Intensity \\
\hline- & - & Hispaniola & $\begin{array}{l}\text { (Perrey, 1857): During the month of July there were twenty tremors. } \\
\text { (Tippenhauer, 1893): July 1770, } 20 \text { shocks. }\end{array}$ & - \\
\hline
\end{tabular}

\section{August, 1770}

Time: Unknown

Phenomenon Notes: Aftershocks of June 3, 1770

Number of Observations: 1

\begin{tabular}{l|l|l}
\hline Longitude & Latitude & City \\
\hline
\end{tabular}

\begin{tabular}{l|l|l}
\hline- & - & Hispaniola
\end{tabular}

\section{Description}

(Perrey, 1857): There were only nine during the month of August; the number and violence (of the shocks) decreasing the rest of the year.

(Tippenhauer, 1893): August 1770, 9 shocks.

\section{December 3, 1770 \\ Time: Unknown}

Phenomenon Notes: Possible Aftershock

Number of Observations: 1

\begin{tabular}{|l|l|l|l|l|}
\hline Longitude & Latitude & City & Description \\
\hline-72.8668 & 18.4315 & Petit Goave & $\begin{array}{l}\text { (Moreau de St. Méry, 1798): *** that of December 3, 1770 there was only } \\
\text { one house left in the city, and two cracked wings of the barracks that were } \\
\text { made of masonry. }\end{array}$ \\
(Tippenhauer, 1893): December 3.
\end{tabular}

\section{July 10, 1771}

Time: $6: 14$ in the morning, Cap Haitien local time

Phenomenon Notes: None

Number of Observations: 2 


\begin{tabular}{|l|l|l|l|l|}
\hline July 10, 1771 & Description & Intensity \\
\hline Longitude & Latitude & City & $\begin{array}{l}\text { (Moreau de St. Méry, 1798): A small one was observed in July 10, 1771 at } \\
\text { 6:14 in the morning, with a stronger one at 4 o'clock in the morning on the } \\
\text { October 3, of that same year, right before the collapse of the church arch, } \\
\text { and one violent one on August 4, 1776 at 4 in the morning. } \\
\text { (Tippenhauer, 1893): July 10, 6:00 early, duration 2 seconds, N-S direction, } \\
\text { Cap Haitien. }\end{array}$ \\
\hline-72.2006 & 19.7616 & Cap Haitien & $\begin{array}{l}\text { (Moreau de St. Méry, 1798): On the July 10, 1771, the earth shook at } 6 \text { in the } \\
\text { morning from the direction of North to South. The shaking lasted 2 seconds. } \\
\text { (Tippenhauer, 1893): July 10, 6:15 evening, Port-au-Prince. }\end{array}$ \\
\hline
\end{tabular}

\section{October 3, 1771}

Time: $4: 00$ in the morning, Cap Haitien local time

Phenomenon Notes: None

Number of Observations: 1

\begin{tabular}{|l|l|l|l|l|}
\hline Longitude & Latitude & City & Description & Intensity \\
\hline-72.2006 & 19.7616 & Cap Haitien & $\begin{array}{l}\text { (Moreau de St. Méry, 1798): A small one was observed in July 10, 1771 at } \\
6: 14 \text { in the morning, with a stronger one at 4 o'clock in the morning on the } \\
\text { October 3, of that same year, right before the collapse of the church arch, } \\
\text { and one violent one on August 4, 1776 at 4 in the morning. }\end{array}$ \\
\hline
\end{tabular}

\section{January 30, 1776 \\ Time: Unknown}

Phenomenon Notes: None

Number of Observations: 1

\begin{tabular}{|l|l|l|l|l|}
\hline Longitude & Latitude & City & Description \\
\hline- & - & Hispaniola - Spanish side & (de Utrera, 1995): 30 of January, eastern side of the island. \\
& & (Tippenhauer, 1893): January 30, Spanish side. \\
\hline
\end{tabular}

\section{August 4, 1776}

Time: $4: 00$ in the morning, Cap Haitien local time

Phenomenon Notes: None

Number of Observations: 1 


\begin{tabular}{|l|l|l|l|l|}
\hline \multicolumn{2}{|l|}{ August 4, 1776} & Description \\
\hline Longitude & Latitude & City & $\begin{array}{l}\text { (Moreau de St. Méry, 1798): A small one was observed in July 10, 1771 at } \\
6: 14 \text { in the morning, with a stronger one at 4 o'clock in the morning on the } \\
\text { October 3, of that same year, right before the collapse of the church arch, } \\
\text { and one violent one on August 4, 1776 at 4 in the morning. }\end{array}$ \\
\hline
\end{tabular}

\begin{tabular}{|l|l|l|l|l|}
\hline \multicolumn{4}{|l|}{ February 11, 1783 } \\
\hline $\begin{array}{l}\text { Time: Unknown } \\
\text { Phenomenon Notes: None } \\
\text { Number of Observations: } 2\end{array}$ \\
\hline Longitude & Latitude & City & Description & Intensity \\
\hline-70.7075 & 19.4502 & Santiago de los Caballeros & $\begin{array}{l}\text { (de Utrera, 1995): 11 and 12 of February, Santiago de los Caballeros, serious } \\
\text { damage to the churches and houses made of brick. }\end{array}$ & - \\
\hline-72.3400 & 18.5400 & Port-au-Prince & $\begin{array}{l}\text { (Moreau de St. Méry, 1798): We did not feel earthquakes until } 11 \text { and } 12 \text { of } \\
\text { February 1783, there were three of which 2 were quite strong. }\end{array}$ & - \\
\hline
\end{tabular}

\begin{tabular}{|c|c|c|c|c|}
\hline \multicolumn{5}{|c|}{ July 25, 1784} \\
\hline \multicolumn{5}{|c|}{$\begin{array}{l}\text { Time: } 6: 14 \text { in the morning, Cap Haitien local time } \\
\text { Phenomenon Notes: None } \\
\text { Number of Observations: } 2\end{array}$} \\
\hline-72.2006 & 19.7616 & Cap Haitien & $\begin{array}{l}\text { (Moreau de St. Méry, 1798): In the year 1784, there were four strong } \\
\text { earthquakes in the Cape; one on July 25, at 6:14 in the morning, with three } \\
\text { tremors of considerable strength and movement directed in a South-West to } \\
\text { North-East direction. The second on August 24, at 1:03 in the morning; the } \\
\text { third on September 29, at 11:25 in the evening and the fourth on November } \\
27 . \\
\text { (Tippenhauer, 1893): July 25, 6:45 evening, SW-NE direction, Cap Haitien } \\
\text { and Fort Dauphin [Fort Liberte], fairly strong, } 3 \text { shocks. }\end{array}$ & - \\
\hline-72.3400 & 18.5400 & Port-au-Prince & $\begin{array}{l}\text { (Moreau de St. Méry, 1798): In July, 1784, we felt two slight (tremors) } \\
\text { directed in an East to West direction. One on August 28, and one on } \\
\text { December } 11 . \\
\text { (Tippenhauer, 1893): July 25, 6:14 evening, E-W (?) direction, Port-au- } \\
\text { Prince, } 2 \text { shocks. }\end{array}$ & - \\
\hline
\end{tabular}




\begin{tabular}{|c|c|c|c|c|}
\hline \multirow{2}{*}{\multicolumn{5}{|c|}{$\begin{array}{l}\text { July 29, } 1784 \\
\text { Time: 9:10 in the evening (?) Cap Haitien local time } \\
\text { Phenomenon Notes: None } \\
\text { Number of Observations: } 3\end{array}$}} \\
\hline & & & & \\
\hline Longitude & Latitude & City & Description & Intensity \\
\hline-72.2006 & 19.7616 & Cap Haitien & $\begin{array}{l}\text { (Perrey, 1843): } 29 \text { of July in the Cape, strong shaking. The Cape had } 12 \\
\text { houses thrown down. } \\
\text { (Tippenhauer, 1893): July 29, 9:10 evening, Cap Haitien. }\end{array}$ & - \\
\hline-72.6929 & 19.4458 & Leogane & (Perrey, 1843): Leogane suffered greatly and Goave was completely ruined. & - \\
\hline-72.8668 & 18.4315 & Petit Goave & (Perrey, 1843): Leogane suffered greatly and Goave was completely ruined. & - \\
\hline
\end{tabular}

\section{January 10, 1785}

Time: 9:30 in the morning, Cap Haitien local time

Phenomenon Notes: None

Number of Observations: 1

\begin{tabular}{|l|l|l|l|l|}
\hline Longitude & Latitude & City & Description \\
\hline-72.2006 & 19.7616 & Cap Haitien & $\begin{array}{l}\text { (Moreau de St. Méry, 1798): January 10, at 9:03 in the morning, violent } \\
\text { shaking from an earthquake } * * \text { there were three in 1785; one on January } \\
\text { 10, the second on February 19, and the third and strongest one on July 10 at } \\
\text { night. }\end{array}$ \\
$\begin{array}{l}\text { (Tippenhauer, 1893): January 10, before 9:30, Fort Liberté and Cap Haitien, } \\
\text { the shock was accompanied by a startling noise. }\end{array}$ \\
\hline
\end{tabular}

\section{December, 1786}

Time: Unknown

Phenomenon Notes: None

Number of Observations: 2

\begin{tabular}{|l|l|l|l|l|}
\hline Longitude & Latitude & City & Description \\
\hline-72.2006 & 19.7616 & Cap Haitien & $\begin{array}{l}\text { (Moreau de St. Méry, 1798): One was felt in 1786 in the month of December. } \\
\text { (Tippenhauer, 1893): December, Cap Haitien and Plaisance. }\end{array}$ \\
\hline-72.4685 & 19.5974 & Plaisance & $\begin{array}{l}\text { (Moreau de St. Méry, 1798): During the two months of November and } \\
\text { December 1786, it was felt in Plaisance four tremors from earthquakes from } \\
\text { the North-East. }\end{array}$ \\
\hline
\end{tabular}




\section{Earthquakes of the $19^{\text {th }}$ Century:}

Intensity, Mercalli Magnitude Intensities (3-10); CHF, assigned by C. H. Flores (author); WHB, assigned by W. H. Bakun (author); SISF, assigned by (SiSFrance/Antilles (2010); S\&L1992, assigned by Shepherd and Lynch (1992); T\&R1977, Tomblin and Robson (1977); C1972, assigned by Campbell (1972); , no assignment given.

\begin{tabular}{|c|c|c|c|c|}
\hline \multicolumn{5}{|c|}{ November 20, 1818} \\
\hline \multicolumn{5}{|c|}{$\begin{array}{l}\text { Time: Unknown } \\
\text { Phenomenon Notes: None } \\
\text { Number of Observations: } 1\end{array}$} \\
\hline Longitude & Latitude & City & Description & Intensity \\
\hline-72.2006 & 19.7616 & Cap Haitien & $\begin{array}{l}\text { (Gay-Lussac and Arago, 1818): } * * * \text { there have been eight earthquakes since } \\
\text { the months of December up to that of May. } \\
\text { (Moreau de Jonnes, 1822): Two strong tremors. } \\
\text { (Gay-Lussac, 1826): November 20; Cap Henry (Haiti); two strong tremors. } \\
\text { (Mallet and Mallet, 1858): Nov. 20, } 1818 \text { - Cape Henri [Cap Haitien] in St. } \\
\text { Domingo, Two severe shocks, Five persons were killed and some houses } \\
\text { were destroyed. } \\
\text { (Tippenhauer, 1893): November 20, Cap Haitien. }\end{array}$ & - \\
\hline
\end{tabular}

\begin{tabular}{|c|c|c|c|c|}
\hline \multicolumn{5}{|c|}{ December 20, 1818} \\
\hline Longitude & Latitude & City & Description & Intensity \\
\hline
\end{tabular}




\begin{tabular}{|c|c|c|c|c|}
\hline \multicolumn{5}{|c|}{ November 19, 1825} \\
\hline \multicolumn{5}{|c|}{$\begin{array}{l}\text { Time: In the morning } \\
\text { Phenomenon Notes: None } \\
\text { Number of Observations: } 1\end{array}$} \\
\hline Longitude & Latitude & City & Description & Intensity \\
\hline-72.3388 & 18.5432 & Port-au-Prince & $\begin{array}{l}\text { (Gay-Lussac and Arago, 1825): November 19, } 1825 \text { - in the morning, Port-au- } \\
\text { Prince, Violent tremors. } \\
\text { (Perrey, 1847; Perrey, 1843): In the morning, in Port-a-Prince, violent shaking } \\
\text { for } 4 \text { to } 5 \text { seconds with a thud from the south-east; the } 3 \text { rd this year. } \\
\text { (Mallet and Mallet, 1858): Violent shocks lasting four or five seconds. This is } \\
\text { said to have been the third earthquake of the year, Accompanied by a dull } \\
\text { noise coming from the SE. }\end{array}$ & - \\
\hline
\end{tabular}

\section{March 31, 1829}

Time: $4: 30$ in the evening, Port-au-Prince local time

Phenomenon Notes: None

Number of Observations: 1

\begin{tabular}{|l|l|l|l|l|}
\hline Longitude & Latitude & City & Description \\
\hline-72.3388 & 18.5432 & Port-au-Prince & $\begin{array}{l}\text { (Le Constitutionnel, 1829): It was felt here [Port-a-Prince], March 31, at half } \\
\text { past four in the evening, two strong shocks from earthquakes, which } \\
\text { fortunately have not been detrimental. }\end{array}$ \\
(Gay-Lussac and Arago, 1829): On March 31, 4h. 1/2 in the afternoon; Port-au- \\
Prince, Haiti, two strong tremors. \\
(Perrey, 1843): March 31, 4:30 in the evening, in Port-au-Prince (Haiti), 2 \\
strong shocks.
\end{tabular}

\section{March 29, 1830 to March 30, 1830}

Time: $11: 30$ at night, 12:30 (half past midnight) and 1:00 in the morning, Port-au-Prince local time

Phenomenon Notes: Three shocks occurred over a period of 3 hours.

Number of Observations: 1

\begin{tabular}{|c|c|c|c|c|}
\hline Longitude & Latitude & City & Description & Intensity \\
\hline-72.3388 & 18.5432 & Port-au-Prince & $\begin{array}{l}\text { (Eyries and others, 1830): A captain who was in Santo Domingo [island] } \\
\text { where the latest earthquakes were felt on this island, has recounted this } \\
\text { event in the following manner: "On March 29, three violent shakes shook }\end{array}$ & - \\
\hline
\end{tabular}




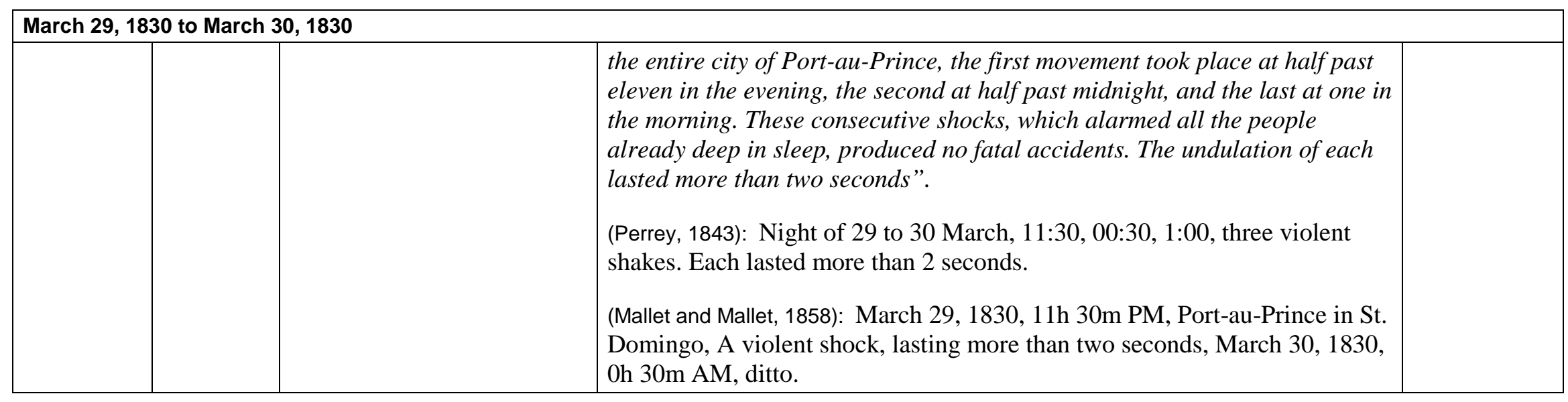

\begin{tabular}{|c|c|c|c|c|}
\hline April 14, 18 & & & & \\
\hline $\begin{array}{l}\text { Time: } 6: 30 \\
\text { Phenomen } \\
\text { Number of }\end{array}$ & $\begin{array}{l}\text { the evenin } \\
\text { Notes: A } \\
\text { bservation }\end{array}$ & $\begin{array}{l}\text { Port-au-Prince local time } \\
\text { felt by ships at sea. } \\
1\end{array}$ & & \\
\hline Longitude & Latitude & City & Description & Intensity \\
\hline
\end{tabular}




\begin{tabular}{|l|l|l|l|}
\hline \multicolumn{2}{|l|}{ April 14, 1830} & & severely. \\
\hline & & & \\
\hline
\end{tabular}

\begin{tabular}{|c|c|c|c|c|}
\hline \multicolumn{5}{|c|}{ September 6, 1840} \\
\hline Longitude & Latitude & City & Description & Intensity \\
\hline
\end{tabular}

\begin{tabular}{|c|c|c|c|c|}
\hline \multicolumn{5}{|c|}{ April 13, 1841} \\
\hline Longitude & Latitude & City & Description & Intensity \\
\hline
\end{tabular}

\section{May 7, 1842}

Time: About 5:37 in the evening, Santo Domingo local time

Land Surface Observations: The Yaque River near Santiago split and one of the splits reversed flow direction for a short period before returning to its normal flow (Ardouin, 1860). Salt and bitumen (?) springs appeared along the coastal mountains. The Ozama river in Santo Domingo overflowed causing ships tied along the river to run aground and pitch strongly. The mountain behind St. Marc was said to have divided in two with a fissure wide enough for a carriage to pass (El Constitucional, 1842a).

Tsunami: Observed first outflow of 200 paces and then inflow 15 feet tall at Port-de-Paix and the sea overtook the river deltas of the Yaque in Monte Cristi and Massacre near Fort Liberte flooding the neighboring regions (Ardouin, 1860). High waves were noticed in Anse-a-Veau and Jeremie on the southern peninsula. Aftershocks: Several aftershocks felt for hours and many felt for days after the event. Besides the cities most affected by the initial shocks, aftershocks were felt as far away as Añasco, Puerto Rico.

Phenomenon Notes: Some sources record this event as being as long as five minutes. However, Puerto Plata and Port-au-Prince describe two shocks in very close succession, the second of the two being stronger and more powerful. About half of the population of Cap Haitien died and about 2,000 died combined between Santiago de los Caballeros and La Vega. This earthquake was far reaching in that ground oscillations were observed in various bodies of water in Louisiana (L'Ami de la Religion, 1842b).

Number of Observations: 50

\begin{tabular}{|l|l|l|l|l|}
\hline Longitude & Latitude & City & Description & Intensity \\
\hline-72.2006 & 19.7616 & Cap Haitien & $\begin{array}{l}\text { (L'Ami de la Religion, 1842a): A correspondent has written to us from Cap } \\
\text { Haitien, on board the Condor, on May 12, and that not a single house stands }\end{array}$ & $\begin{array}{l}\text { CHF(9) } \\
\text { WHB(9) } \\
\text { SISF(9.5) }\end{array}$ \\
\hline
\end{tabular}




\begin{tabular}{|c|c|c|c|c|}
\hline \multicolumn{5}{|c|}{ May 7, 1842} \\
\hline & & & $\begin{array}{l}\text { after the terrible catastrophe of the 7th. Our correspondent was on a balcony } \\
\text { with a few people at the moment the earthquake began; at each shake a } \\
\text { piece of wall was falling; they lasted forty to fifty seconds, during which a } \\
\text { hail of cinder blocks and stones fell on the unfortunate who sought to } \\
\text { escape. The noise from the falling houses was frightening. The church } \\
\text { which was the pride of the city was ruined from top to bottom. For six } \\
\text { hours, for three to five minutes long, there were repeated shocks * * * Our } \\
\text { correspondent spent a frightful night at the Foselle, among the dead, the } \\
\text { dying and the wounded that did not cease to bring in their friends, after } \\
\text { having withdrawn with difficulty from under the rubble. On the banks there } \\
\text { has been established ambulances filled with the wounded. Port-au-Prince } \\
\text { suffered little. The houses made of wood resisted better than the stone } \\
\text { houses. The fire that burst after the first shock has lasted four days and four } \\
\text { nights. It took only forty-eight hours for the population from the } \\
\text { surrounding villages to come to the city and pillage. At the edge of the sea, } \\
\text { we saw the poor wretches compete for each other's spoils and each other's } \\
\text { throats and remain rightful owners. Many have been killed like ferocious } \\
\text { animals by the armed inhabitants defending their property. Half of the } \\
\text { population perished, and among the foreigners and their clerks, only three } \\
\text { were killed. On May 14, slight shocks still continued, it has not rained and } \\
\text { we dread new misfortunes. }\end{array}$ & $\begin{array}{l}\text { S\&L1992(9) } \\
\text { T\&R1977(9) }\end{array}$ \\
\hline-72.8370 & 19.9408 & Port-de-Paix & $\begin{array}{l}\text { (Public Ledger, 1842): The other towns and villages besides our own and } \\
\text { those enumerated above, which have most seriously suffered (some of } \\
\text { which are entirely demolished,) are Porto Paix, Gonaives, St. Marc, Mole- } \\
\text { St. Nichols, St. Louis du Nord, Fort Dauphine [Fort Liberte], Limbeport, } \\
\text { Margot, Borgne, La Grande Riviere, Laxavon and Altamira, which, together } \\
\text { with Porto Plata [Puerto Plata], Cape Haitien, Santiago, St. Osero [Santa } \\
\text { Cerro], and La Vega, before mentioned, make in all } 17 \text { towns and villages, } \\
\text { with loss of lives in nearly all...The direction taken by the earthquake, } \\
\text { which proved the most severe in its effects, was along the Northern and } \\
\text { North-eastern part; all the other parts of our Island have experienced the } \\
\text { shock, though only in a partial and limited degree. } \\
\\
\text { (Scherer, 1912a): The town of Port de Paix had even more to suffer; it was } \\
\text { thrown down by the shock and overwhelmed by a wave. }\end{array}$ & \begin{tabular}{|l|} 
CHF(9) \\
WHB(9) \\
SISF(9) \\
S\&L1992(9) \\
T\&R1977(9)
\end{tabular} \\
\hline
\end{tabular}




\begin{tabular}{|c|c|c|c|c|}
\hline \multicolumn{5}{|c|}{ May 7, 1842} \\
\hline & & & $\begin{array}{l}\text { of Saint-Nicolas and Port-Paix were destroyed. It is assumed that the } \\
\text { northern towns on the island are also a mass of ruins. } \\
\text { (Scherer, 1912a): Mole St. Nicolas, firmly constructed of stone, was } \\
\text { fortified; it had warehouses, barracks, a fine church and aqueducts bringing } \\
\text { water from a distance. The earthquake ruined it entirely. Of the city only a } \\
\text { "plan par terre" remained and nothing more. }\end{array}$ & $\begin{array}{l}\text { SISF(9) } \\
\text { S\&L1992(9) } \\
\text { T\&R1977(9) }\end{array}$ \\
\hline-71.8397 & 19.6668 & Fort Liberte & $\begin{array}{l}\text { (McCann and others, } 2011 \text { quoting the Jamaica Morning Journal, June 16, 1842): } \\
\text { The villages of Port-Margot, Borgne, Ouanaminthe and the town of Fort } \\
\text { Liberte experienced somewhat approaching a coup-de-grace. } \\
\text { (Scherer, 1912a): The churches of Borgne, of Port Margo, of Fort Liberté - } \\
\text { the most beautiful one in the island - of Limonade, of Quartier Morin, those } \\
\text { of Cap Haitien and of Acul du Nord were completely destroyed or badly } \\
\text { damaged. }\end{array}$ & $\begin{array}{l}\text { CHF(9) } \\
\text { WHB(9) } \\
\text { SISF(8) } \\
\text { S\&L1992(9) } \\
\text { T\&R1977(9) }\end{array}$ \\
\hline-70.7075 & 19.4502 & Santiago de los Caballeros & $\begin{array}{l}\text { (El Constitutional, 1842b): The horrific earthquake that has devastated Haiti } \\
\text { did not spare the ancient Spanish part of the island. The city of Santiago has } \\
\text { been completely destroyed: it is reported that up to } 2000 \text { persons have died. } \\
\text { (Public Ledger, 1842): The fine town of Santiago, about } 60 \text { miles distant in } \\
\text { the interior, and the center of our agricultural commerce in this part, has } \\
\text { been entirely destroyed - the population, consisting of about 6,000 souls, of } \\
\text { which } 500 \text { are buried in the ruins. Further in the interior, the towns of Vega } \\
\text { and St. Osero [Santa Cerro] have met with similar fates. } \\
\text { (Scherer, 1912a): The houses were well constructed, low and without stories, } \\
\text { the parochial church resembled a strong castle, all were thrown down in an } \\
\text { instant, around Santiago, springs appeared and the ground cracked in many } \\
\text { places, Yaqui River suddenly heaved up, drove its waters in a torrent up and } \\
\text { down the stream. The subsidence came about as suddenly and the stream } \\
\text { again took its course. }\end{array}$ & $\begin{array}{l}\text { CHF(9) } \\
\text { WHB(9) } \\
\text { SISF(8) } \\
\text { S\&L1992(9) } \\
\text { T\&R1977(9) }\end{array}$ \\
\hline-70.7816 & 19.4521 & Hato Yaque & $\begin{array}{l}\text { (McCann and others, } 2011 \text { quoting the Jamaica Morning Journal June 22, 1842): } \\
\text { Saint Yague-*** lay in ruins. All its edifices had fallen. } \\
\text { (McCann and others, } 2011 \text { quoting Nouel, 1979): From the place called "Paso } \\
\text { de los Borbones" at the edges of the River Yague in Santiago, to the river } \\
\text { Gurabito, a distance of about half a league, the earth opened along its }\end{array}$ & $\begin{array}{l}\text { CHF(9) } \\
\text { WHB(9) }\end{array}$ \\
\hline
\end{tabular}




\begin{tabular}{|c|c|c|c|c|}
\hline \multicolumn{5}{|c|}{ May 7, 1842} \\
\hline & & & longitude making a wide and deep crevice cutting part of the city. & \\
\hline-72.4291 & 19.7512 & Port Margot & $\begin{array}{l}\text { (McCann and others, } 2011 \text { quoting the Jamaica Morning Journal, June 16, 1842): } \\
\text { The villages of Port-Margot, Borgne, Ouanaminthe and the town of Fort } \\
\text { Liberte experienced somewhat approaching a coup-de-grace. } \\
\text { (Scherer, 1912a): Severe damage, church destroyed or severely damaged. }\end{array}$ & $\begin{array}{l}\mathrm{CHF}(8) \\
\mathrm{WHB}(-)\end{array}$ \\
\hline-70.6937 & 19.7971 & Puerto Plata & $\begin{array}{l}\text { (Public Ledger, 1842, printed letter dated May 20, 1842): On the 7th day of May } \\
\text { the Island of Hayti was visited with an earthquake, which in its destructive } \\
\text { effects has proven itself to be the severest which we have ever had on } \\
\text { record *** In the afternoon of that day, at about half-past } 5 \text { o'clock, I was } \\
\text { standing on the square, which is situated in an elevated part of this town. } \\
\text { The sky was uncommonly serene, and the descending sun promised to be } \\
\text { bright and glorious in its setting. Just then, casting my eyes towards Mount } \\
\text { Isabella, which overlooks the town, I perceived a dark vapor ascending and } \\
\text { enveloping its base and sides - a rolling, rumbling sound immediately } \\
\text { succeeded, and instantaneously came a shock which nearly dashed me to the } \\
\text { ground. The level of the square appeared undulating like the waves of the } \\
\text { sea - a faint and sickly sensation came over me and dizziness and difficulty } \\
\text { in breathing. The houses rocked to and fro like vessels in a storm. The } \\
\text { ground was rent in various parts. Many persons were thrown down by the } \\
\text { force of the concussion; others were reeling as in a state of drunkenness. } \\
\text { Every moment we expected the earth to open and engulf us. A second } \\
\text { shock followed, yet stronger than the former, accompanied by the same } \\
\text { appearances, effects and terrors. The church, a strong, and massive building, } \\
\text { seemed tottering to its fall, - the bricks flew from the solitary masonry as if } \\
\text { from projectiles; while fissures appeared in the walls and arches, and the } \\
\text { whole would have been leveled but for the uncommon strength of the } \\
\text { outside buttresses, and the lowness of the building *** The second shock } \\
\text { must have lasted about } 60 \text { seconds. Fortunately for us, our town is almost } \\
\text { entirely constructed of wood, which alone accounts for its preservation. The } \\
\text { stone buildings suffered materially, and some of the finest were entirely } \\
\text { destroyed. From the } 7 \text { th up to the present date, we have been in a continued } \\
\text { state of alarm - upwards of } 40 \text { shocks having taken place during that }\end{array}$ & $\begin{array}{l}\text { CHF(8) } \\
\text { WHB(7) } \\
\text { SISF(7.5) }\end{array}$ \\
\hline
\end{tabular}




\begin{tabular}{|c|c|c|c|c|}
\hline \multicolumn{5}{|c|}{ May 7, 1842} \\
\hline & & & interval, some more or less severe. & \\
\hline-71.6507 & 19.8474 & Monte Cristi & $\begin{array}{l}\text { (McCann and others, } 2011 \text { quoting the Jamaica Morning Journal, June 22, 1842): } \\
\text { St. Louis- in the north, there has been much damage done, as also at } \\
\text { Montecristi. }\end{array}$ & $\begin{array}{l}\text { CHF(7.5) } \\
\text { WHB(-) }\end{array}$ \\
\hline-72.3197 & 19.6803 & Acul du Nord & $\begin{array}{l}\text { (Scherer, 1912a): The churches of Borgne, of Port Margo, of Fort Liberté - } \\
\text { the most beautiful one in the island - of Limonade, of Quartier Morin, those } \\
\text { of Cap Haitien and of Acul du Nord were completely destroyed or badly } \\
\text { damaged. }\end{array}$ & $\begin{array}{l}\mathrm{CHF}(7) \\
\operatorname{WHB}(7)\end{array}$ \\
\hline-72.5230 & 19.8463 & Borgne & $\begin{array}{l}\text { (McCann and others, } 2011 \text { quoting the Jamaica Morning Journal, June 16, 1842): } \\
\text { The villages of Port-Margot, Borgne, Ouanaminthe and the town of Fort } \\
\text { Liberte experienced somewhat approaching a coup-de-grace. } \\
\text { (Scherer, 1912a): Severe damage, church destroyed or severely damaged. }\end{array}$ & $\begin{array}{l}\mathrm{CHF}(7) \\
\operatorname{WHB}(7)\end{array}$ \\
\hline-72.2186 & 19.6047 & Sans Souci Palace & $\begin{array}{l}\text { (Scherer, 1912a): And the majestic palace, Sans Souci, of king Christopher, } \\
\text { with the church, suffered the same fate. [completely destroyed or badly } \\
\text { damaged] }\end{array}$ & $\begin{array}{l}\text { CHF(7) } \\
\text { WHB(7) }\end{array}$ \\
\hline
\end{tabular}




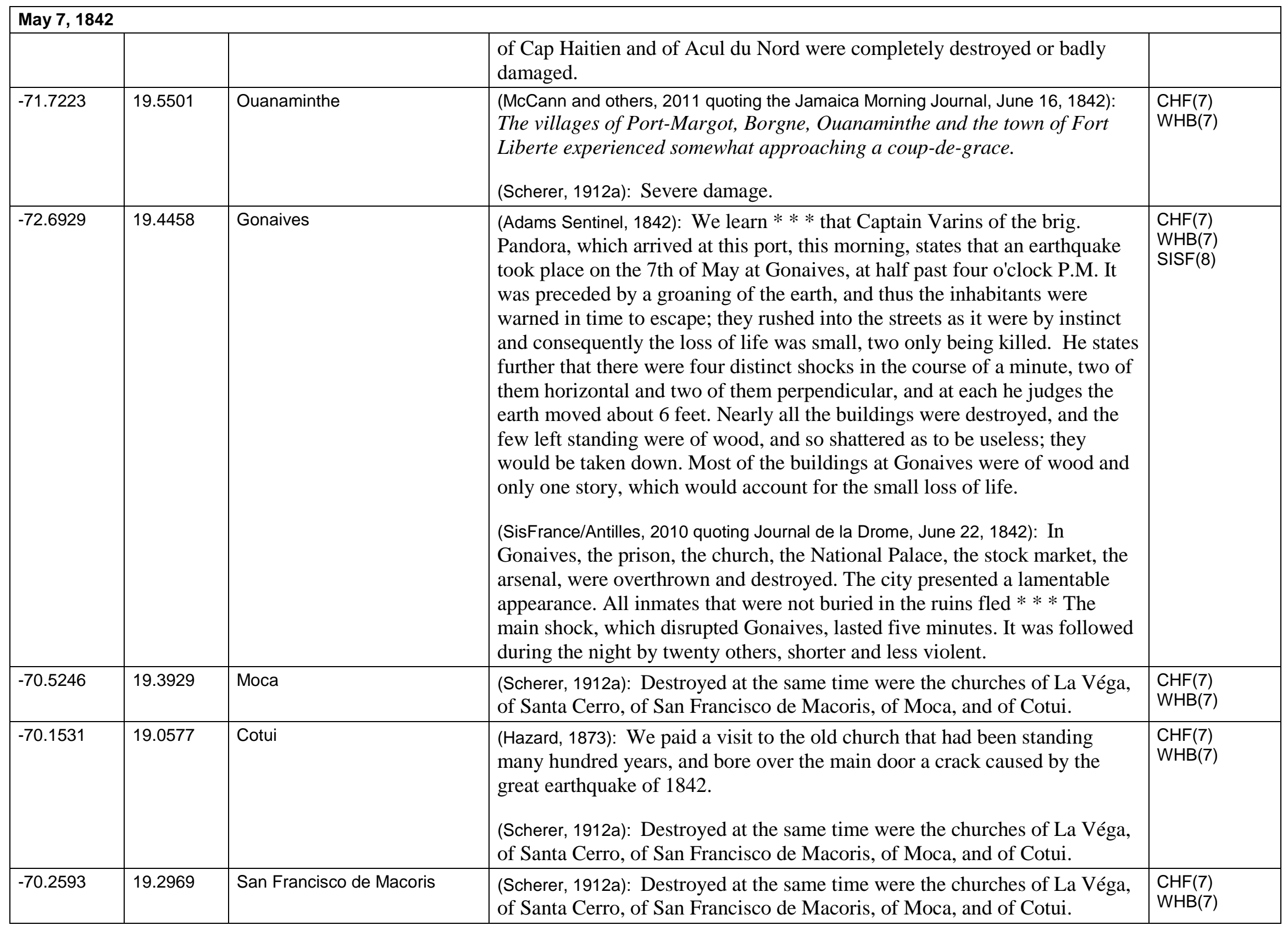




\begin{tabular}{|c|c|c|c|c|}
\hline \multicolumn{5}{|c|}{ May 7, 1842} \\
\hline-70.5468 & 19.2797 & Santa Cerro & $\begin{array}{l}\text { (Public Ledger, 1842): The fine town of Santiago, about } 60 \text { miles distant in } \\
\text { the interior, and the center of our agricultural commerce in this part, has } \\
\text { been entirely destroyed - the population, consisting of about 6,000 souls, of } \\
\text { which } 500 \text { are buried in the ruins. Further in the interior, the towns of Vega } \\
\text { and St. Osero [Santa Cerro] have met with similar fates. } \\
\text { (Scherer, 1912a): Destroyed at the same time were the churches of La Véga, } \\
\text { of Santa Cerro, of San Francisco de Macoris, of Moca, and of Cotui. } \\
\text { (de Utrera, 1995): The church fell to the ground in } 1842 .\end{array}$ & $\begin{array}{l}\mathrm{CHF}(7) \\
\operatorname{WHB}(7)\end{array}$ \\
\hline-69.8877 & 18.4722 & Santo Domingo & $\begin{array}{l}\text { (La Presse, 1842): The letters from Saint-Domingue, May 14, announce that } \\
\text { the city shook, on the 7, by an earthquake that lasted } 2 \text { minutes. The city } \\
\text { suffered greatly; the inhabitants in fear deserted their homes. The Ozama } \\
\text { river grew suddenly three meters. } \\
\text { (Journal de Débats Politiques et Littéraires, 1842): Letters come directly from } \\
\text { Santo Domingo; we provide details on the cursed effects from the southern } \\
\text { part of the island. Here are excerpts from letters contained in the Journal du } \\
\text { Havre from the 27th: May 14, 1842. "Since the 7th instant, at five hours } \\
\text { thirty-two minutes in the afternoon, our poor city of Santo Domingo } \\
\text { plunged into the deepest desolation as a result of the horrible earthquake } \\
\text { that lasted about eighty-five seconds and whose oscillations and violent } \\
\text { shaking put our houses in a state of ruin making them uninhabitable. Three } \\
\text { quarters of the inhabitants of the town have been compelled to take refuge } \\
\text { in the suburbs and surrounding areas. The tremors continued with less } \\
\text { violence until yesterday..." Here is an extract from the captain Ducormier, } \\
\text { commanding Le Jean-Maurice who brought the letters from Santo Domingo } \\
\text { previously: "On May 7, 1842, at five hours thirty-seven minutes in the } \\
\text { evening, in Santo-Domingo was felt, and well as in its surroundings, a very } \\
\text { violent earthquake, accompanied by a strong thud from inside the earth. The } \\
\text { first shock was felt from the bottom to top, and the second from north to } \\
\text { south. The sun, which was still above the horizon, no longer gave a low } \\
\text { brightness, and a very thick dust covered the area of the city. For a minute } \\
\text { and a few seconds the earthquake lasted, it would be difficult to express } \\
\text { dismay of the population, saving or jumping from windows, to take refuge } \\
\text { in the squares or middle of the streets to avoid the debris from houses } \\
\text { falling to the ground. The cathedral and many other churches were }\end{array}$ & $\begin{array}{l}\text { CHF(6.5) } \\
\text { WHB(6.5) } \\
\text { SISF(7) } \\
\text { S\&L1992(6) }\end{array}$ \\
\hline
\end{tabular}




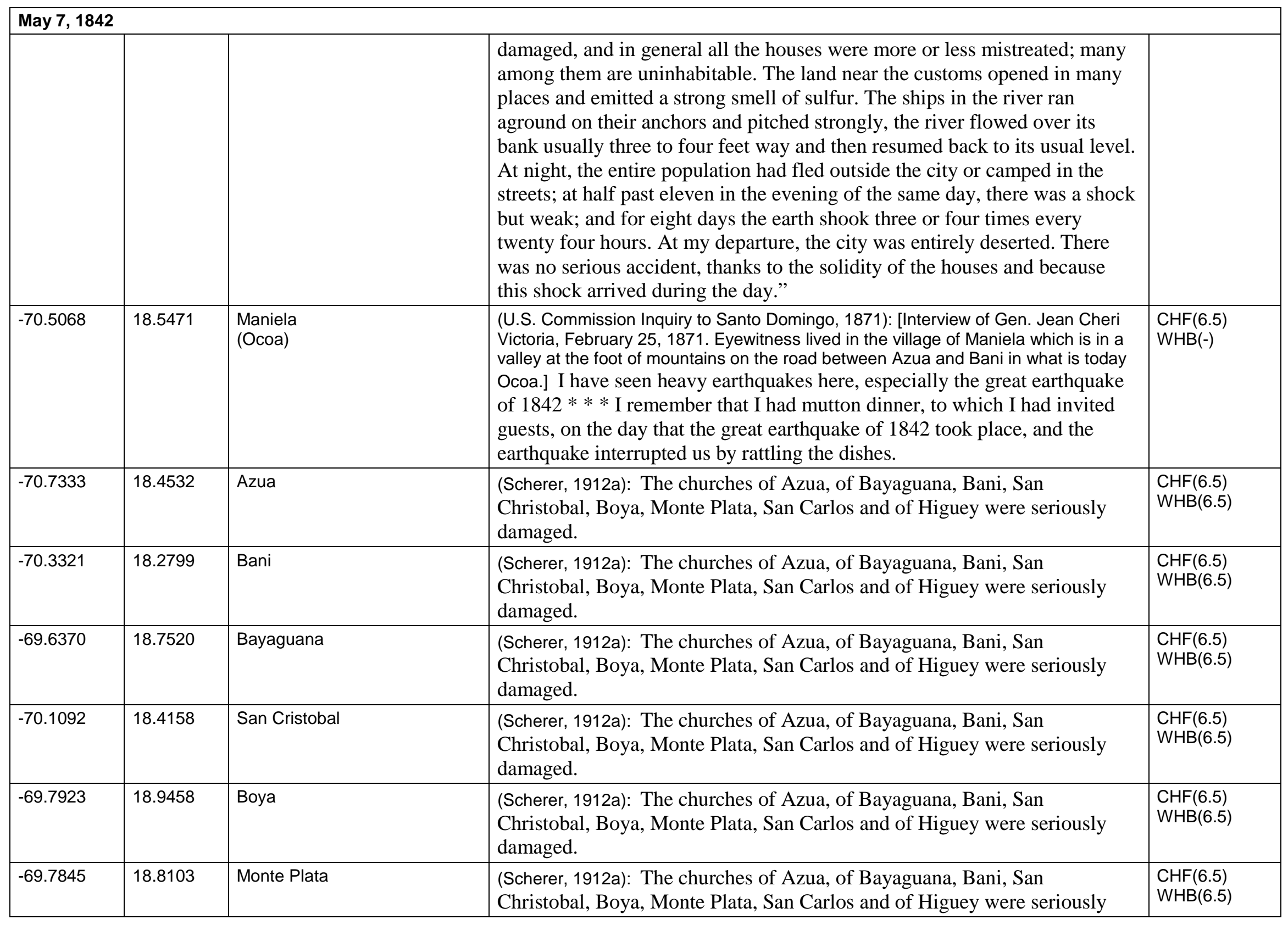




\begin{tabular}{|c|c|c|c|c|}
\hline \multicolumn{5}{|c|}{ May 7, 1842} \\
\hline & & & damaged. & \\
\hline-68.7168 & 18.6154 & Higuey & $\begin{array}{l}\text { (Scherer, 1912a): The churches of Azua, of Bayaguana, Bani, San } \\
\text { Christobal, Boya, Monte Plata, San Carlos and of Higuey were seriously } \\
\text { damaged. }\end{array}$ & $\begin{array}{l}\mathrm{CHF}(6.5) \\
\operatorname{WHB}(6.5)\end{array}$ \\
\hline-72.6978 & 19.1081 & Saint Marc & $\begin{array}{l}\text { (SisFrance/Antilles, } 2010 \text { quoting Journal de la Drome, June 22, 1842): In Saint- } \\
\text { Marc, many houses were damaged, some destroyed but nobody perished. } \\
\text { (El Constitutional, 1842a; L'Ami de la Religion, 1842b): The mountain which is } \\
\text { behind Saint Marc has divided itself into two pieces, with a fissure so wide } \\
\text { that carriages can pass through. }\end{array}$ & $\begin{array}{l}\mathrm{CHF}(6) \\
\text { WHB(6) } \\
\text { SISF(8) }\end{array}$ \\
\hline-72.3388 & 18.5432 & Port-au-Prince & $\begin{array}{l}\text { (SisFrance/Antilles, } 2010 \text { quoting Journal de la Drome, June 22, 1842): In the city } \\
\text { of Port-au-Prince, there were two distinct shocks. The later one lasted three } \\
\text { minutes. The first one was less prolonged. The streets were filled with } \\
\text { people rushing out of their homes, which were expecting a similar } \\
\text { catastrophe like in } 1770 \text {. According to the newspaper Patriote, there is not } \\
\text { a house that has been more or less damaged. The pediment of the Senate } \\
\text { palace, on which were carved the arms of the republic, has detached and } \\
\text { was broken. The shocks were repeated for several days, but they had lost } \\
\text { their violence. } \\
\text { (Annual Register, 1843): Port-au-Prince has suffered also, but only as regards } \\
\text { breakage of glass, \&c. ware and the walls (of two feet thick bricks) cracked } \\
\text { in many places half an inch wide; at one place a brick pillar fell down also. } \\
\text { Even here we could hardly keep on our legs, and the vessels rolled about } \\
\text { very much. }\end{array}$ & $\begin{array}{l}\text { CHF(5) } \\
\text { WHB(5) } \\
\text { SISF(7) } \\
\text { S\&L1992(7) } \\
\text { T\&R1977(7) }\end{array}$ \\
\hline
\end{tabular}




\begin{tabular}{|c|c|c|c|c|}
\hline \multicolumn{5}{|c|}{ May 7, 1842} \\
\hline & & & $\begin{array}{l}\text { 7th May, at half past } 5 * * * \text { terrible commotion is felt, which lasts four } \\
\text { minutes and some seconds. The oscillation from north to south } * * * \text { many } \\
\text { houses[?] have been greatly damaged } * * * \text { suddenly the sea } * * * \text { burst } \\
\text { with fury against the steep rocks with bind the coast } * * * \text { mighty gigantic } \\
\text { waves *** On the following night we continued to feel many shocks. }\end{array}$ & WHB(-) \\
\hline-73.0861 & 18.4395 & Miragoave & $\begin{array}{l}\text { (McCann and others, } 2011 \text { quoting the Jamaica Morning Journal, June 6, 1842): It } \\
\text { appears that all the south-Miragoave, St. Michel, Aquin, Les Cayes and } \\
\text { Jeremie, have very slightly felt the shock. }\end{array}$ & $\begin{array}{l}\text { CHF(3) } \\
\text { WHB(3) }\end{array}$ \\
\hline-73.3971 & 18.2816 & Aquin & $\begin{array}{l}\text { (McCann and others, } 2011 \text { quoting the Jamaica Morning Journal, June 6, 1842): It } \\
\text { appears that all the south-Miragoave, St. Michel, Aquin, Les Cayes and } \\
\text { Jeremie, have very slightly felt the shock. }\end{array}$ & $\begin{array}{l}\text { CHF(3) } \\
\text { WHB(3) }\end{array}$ \\
\hline-73.7500 & 18.1950 & Les Cayes & $\begin{array}{l}\text { (McCann and others, } 2011 \text { quoting the Jamaica Morning Journal, June 6, 1842): It } \\
\text { appears that all the south-Miragoave, St. Michel, Aquin, Les Cayes and } \\
\text { Jeremie, have very slightly felt the shock. }\end{array}$ & $\begin{array}{l}\text { CHF(3) } \\
\text { WHB(3) }\end{array}$ \\
\hline-75.8296 & 20.0209 & Santiago, Cuba & $\begin{array}{l}\text { (Scherer, 1912a): *** and crossing the Windward Passage, the shock was } \\
\text { felt the length of the Sierra Maestra in Cuba. Santiago de Cuba also counts } \\
\text { this earthquake among the strongest the eastern part of the island of Cuba } \\
\text { has experienced. } \\
\text { (Chuy and Pino, 1982): } * * * \text { strongest the eastern part of the island has } \\
\text { experienced, almost all the walls of the houses were cracked and very little } \\
\text { more would have leveled the town. }\end{array}$ & $\begin{array}{l}\text { CHF(5) } \\
\text { WHB(-) } \\
\text { S\&L1992(7) } \\
\text { T\&R1977(7) }\end{array}$ \\
\hline-74.4963 & 20.3459 & Baracoa, Cuba & $\begin{array}{l}\text { (Chuy and Pino, 1982): Strong earthquake, along the outcrops of Yunque and } \\
\text { Marcos Reyes, sections of the outcrops fell that measured about } 20 \text { meters } \\
\text { long and about the same width. }\end{array}$ & $\begin{array}{l}\text { CHF(5) } \\
\text { WHB(-) } \\
\text { S\&L1992(8) }\end{array}$ \\
\hline-71.1462 & 21.4674 & $\begin{array}{l}\text { Cockburn Town, } \\
\text { Grand Turks Island }\end{array}$ & $\begin{array}{l}\text { (McCann and others, } 2011 \text { quoting The Morning Journal Kingston Jamaica, May 17, } \\
\text { 1842): On the arrival of the Tweed at Turk's Island on the following evening } \\
\text { [May 8] it was ascertained that a smart shock of an earthquake had been felt } \\
\text { on the previous evening at five o'clock but no damage had been sustained. }\end{array}$ & $\begin{array}{l}\text { CHF(4) } \\
\text { WHB(4) } \\
\text { SISF(5) } \\
\text { S\&L1992(5) } \\
\text { T\&R1977(5) }\end{array}$ \\
\hline
\end{tabular}




\begin{tabular}{|c|c|c|c|c|}
\hline \multicolumn{5}{|c|}{ May 7, 1842} \\
\hline & & & $\begin{array}{l}\text { (Tomblin and Robson, 1977): Turks Island - A severe shock of earthquake, } \\
\text { Glassware rattled, salt ponds agitated. }\end{array}$ & \\
\hline-67.1414 & 18.2885 & Añasco, Puerto Rico & $\begin{array}{l}\text { (McCann and others, } 2011 \text { quoting Rodriguez, 1842): } * * * \text { that we need in this } \\
\text { sacred parochial church [Añasco] to make repairs from the damages } \\
\text { suffered as a result of the fierce earthquake that was experienced on May } \\
7 \text { th last with frequent reoccurrences } * * * \text { the roof work has been moved } \\
\text { and broken by the effects of before mentioned earthquake. }\end{array}$ & $\begin{array}{l}\mathrm{CHF}(5) \\
\mathrm{WHB}(5)\end{array}$ \\
\hline-66.1057 & 18.4665 & San Juan, Puerto Rico & $\begin{array}{l}\text { (El Constitucional, 1842c): By communication of the Captain General - } \\
\text { Governor of Puerto Rico dated June } 4 \text { past, we know that tranquility } \\
\text { continues on the island; and even though they experienced on that evening } \\
\text { of May } 7 \text { last the strong earthquake that caused such destruction on the } \\
\text { island of Santo Domingo, it did not produce more destruction other than the }\end{array}$ & \begin{tabular}{|l|} 
CHF(3) \\
WHB(3) \\
S\&L1992(5) \\
T\&R1977(5)
\end{tabular} \\
\hline
\end{tabular}




\begin{tabular}{|c|c|c|c|c|}
\hline \multicolumn{5}{|c|}{ May 7,1842} \\
\hline & & & injury of only a few buildings. & \\
\hline-76.7929 & 17.9711 & Kingston, Jamaica & $\begin{array}{l}\text { (McCann and others, } 2011 \text { quoting The Morning Journal Kingston, Jamaica May 13, } \\
\text { 1842): The Falmouth Post reports that the earthquake which was felt in this } \\
\text { town on Saturday evening last [by Jamaican count this would be May 7], } \\
\text { was also felt at Falmouth. There were three distinct shocks; it adds which } \\
\text { appeared to vibrate from N.W. to S. } \\
\text { (Hall, 1922): 1842, May 7, 3:15 PM, III - Shock sufficient to make houses } \\
\text { rock. } \\
\text { (Tomblin and Robson, 1977): Smart shock felt. }\end{array}$ & \begin{tabular}{|l|} 
CHF(3) \\
WHB(3) \\
S\&L1992(5) \\
T\&R1977(5)
\end{tabular} \\
\hline-77.6575 & 18.4928 & Falmouth, Jamaica & $\begin{array}{l}\text { (McCann and others, } 2011 \text { quoting The Morning Journal Kingston, Jamaica May 13, } \\
\text { 1842): The Falmouth Post reports that the earthquake which was felt in this } \\
\text { town on Saturday evening last (by Jamaican count this would be May 7), } \\
\text { was also felt at Falmouth. There were three distinct shocks; it adds which } \\
\text { appeared to vibrate from N.W. to S. }\end{array}$ & $\begin{array}{l}\mathrm{CHF}(3) \\
\operatorname{WHB}(3)\end{array}$ \\
\hline
\end{tabular}

\section{May 7, 1842, to June 28, 1842}

Time: after 5:30 PM Santo Domingo local time on May 7th

Phenomenon Notes: Description of aftershocks in various places at various times of the day.

Number of Observations: 4

\begin{tabular}{|l|l|l|l|}
\hline Longitude & Latitude & City & Description \\
\hline-69.8877 & 18.4722 & Santo Domingo & $\begin{array}{l}\text { (Mallet and Mallet, 1858): Succeeded by many slighter shocks on the 8th, 9th, } \\
\text { and perhaps 10th. June 24 5h 30m AM, island St. Domingo, very severe } \\
\text { shocks. }\end{array}$ \\
& $\begin{array}{l}\text { (Garcia, 1900): [Aftershocks felt] Between } 8 \text { and } 9 \text { at night there was a small } \\
\text { tremor that was repeated again between } 9 \text { and } 10 \text { at night, adding to the } \\
\text { panic already caused by the catastrophe. On the 9th the earth shook again } \\
\text { between 9 and 10 in the morning and at } 11: 30 \text { there was another stronger } \\
\text { tremor that was repeated at around 1 in the afternoon. On the 10th, there } \\
\text { were two shocks at 7:30 and at 8:30 at night although both lightly and this } \\
\text { was repeated at midnight. On the 11th, at about 2:30 in the morning there }\end{array}$ &
\end{tabular}




\begin{tabular}{|c|c|c|c|c|}
\hline May 7,18 & June 2 & & & \\
\hline & & & $\begin{array}{l}\text { was also a shock, another between } 4: 30 \text { and } 5 \text { in the morning and again at } \\
10 \text { at night. On the } 12 \text { th there was also a tremor at about } 6 \text { in the morning, } \\
\text { on the } 14 \text { at about } 8 \text { at night, on the } 15 \text { th there were two late at night, on the } \\
\text { 16th there was one at } 2 \text { in the morning, on the } 23 r d \text { there were two, one } \\
\text { around } 4 \text { in the afternoon and another at about } 6: 30 \text { at night, on the 6th of } \\
\text { June it was said that three shocks occurred at night and another on the } 27 \text { th } \\
\text { of June at about } 11 \text { at night, and two on the 28th, one at } 3 \text { in the morning } \\
\text { and the other between } 4 \text { and } 5 \text { in the morning with very strong shaking. } \\
\text { (de Utrera, 1995): June 21, 1842, eastern part. [Hispaniola] }\end{array}$ & \\
\hline-67.1407 & 18.2009 & Mayaguez, Puerto Rico & $\begin{array}{l}\text { (McCann and others, } 2011 \text { quoting The Charleston Daily Courier, June 20, 1842): } \\
\text { Earthquake - Capt. Ward of the barque Condor which arrived yesterday } \\
\text { morning from Mayaguez, informs us that the earthquake on the 7th of May } \\
\text { was very severely felt there; and that up to the } 30 \text { of May when he sailed, } \\
\text { there were from two to three shocks a day. The inhabitants were very fearful } \\
\text { of a similar shock to that which was felt on the 7th in other places. }\end{array}$ & \\
\hline
\end{tabular}

\section{February 22, 1843, and March 22, 1843}

\section{Time: Unknown}

Phenomenon Notes: Tippenhauer (1893) and de Utrera (1995) also mention another earthquake on March 22, 1843.

Number of Observations: 1

\begin{tabular}{|l|l|l|l|}
\hline Longitude & Latitude & City & Description \\
\hline- & - & Eastern part of Hispaniola & $\begin{array}{l}\text { (Perrey, 1843): Three large shakes were felt, on the eastern part of Santo } \\
\text { Domingo [island]. }\end{array}$ \\
& & $\begin{array}{l}\text { (Tippenhauer, 1893): February 22, east of Santo Domingo, 3 shocks; March } \\
\text { 22, east of Santo Domingo. }\end{array}$ \\
\hline
\end{tabular}




\begin{tabular}{|c|c|c|c|c|}
\hline \multicolumn{5}{|c|}{ September 15, 1846} \\
\hline \multicolumn{5}{|c|}{$\begin{array}{l}\text { Time: } 11: 00 \text { PM, Cap Haitien local time } \\
\text { Phenomenon Notes: None } \\
\text { Number of Observations: } 1\end{array}$} \\
\hline Longitude & Latitude & City & Description & Intensity \\
\hline-72.2006 & 19.7616 & Cap Haitien & $\begin{array}{l}\text { (Perrey, 1856): September 15, 1846, } 11 \text { o'clock at night, in Cap Haitien, } \\
\text { Santo Domingo [Hispaniola]. }\end{array}$ & - \\
\hline
\end{tabular}

\begin{tabular}{|c|c|c|c|c|}
\hline \multicolumn{5}{|c|}{ September 16, 1846} \\
\hline \multicolumn{5}{|c|}{$\begin{array}{l}\text { Time: Unknown } \\
\text { Phenomenon Notes: None } \\
\text { Number of Observations: } 1\end{array}$} \\
\hline Longitude & Latitude & City & Description & Intensity \\
\hline-69.8877 & 18.4722 & Santo Domingo & $\begin{array}{l}\text { (Perrey, 1856): September 16, 1846, city of Santo Domingo, two tremors. } \\
\text { (Tippenhauer, 1893): September 16, Santo Domingo. } \\
\text { (de Utrera, 1995): September 16, } 1846 \text { - Santo Domingo. }\end{array}$ & - \\
\hline
\end{tabular}

\section{September 18, 1846}

Time: Unknown

Phenomenon Notes: None

Number of Observations: 1

\begin{tabular}{|l|l|l|l|l|}
\hline Longitude & Latitude & City & Description \\
\hline-72.2006 & 19.7616 & Cap Haitien & $\begin{array}{l}\text { (Perrey, 1856): September 18, 1846; again at Cap Haitien, Santo Domingo } \\
\text { [Hispaniola]. } \\
\text { (Tippenhauer, 1893): September 18, Cap Haitien. }\end{array}$ \\
\hline
\end{tabular}

\section{June(?) 1849}

Time: Unknown

Phenomenon Notes: Poey (1857) suggests this event might have occurred in the month of June. The sources refer to the island of Hispaniola and not the city of Santo Domingo.

Number of Observations: 1

\begin{tabular}{|l|l|l|}
\hline Longitude & Latitude & City \\
\hline
\end{tabular}
Description 


\begin{tabular}{|l|l|l|l|l|}
\hline June(?) 1849 & Hispaniola & $\begin{array}{l}\text { (La Presse, 1849): There is no new politics in Santo Domingo, where there } \\
\text { has been an earthquake that fortunately has not caused great damage. } \\
\text { (Perrey, 1850 a \& b): La Presse July } 18 \text { also said there was at St. Domingo an } \\
\text { earthquake that fortunately has not caused great damages. } \\
\text { (Poey, 1857): Probably in June? } \\
\text { (de Utrera, 1995): 1849 Santo Domingo. }\end{array}$ \\
\hline
\end{tabular}

\begin{tabular}{|c|c|c|c|c|}
\hline \multicolumn{5}{|c|}{ April 8, 1852} \\
\hline \multicolumn{5}{|c|}{$\begin{array}{l}\text { Time: Unknown } \\
\text { Phenomenon Notes: None } \\
\text { Number of Observations: } 1\end{array}$} \\
\hline Longitude & Latitude & City & Description & Intensity \\
\hline
\end{tabular}

\begin{tabular}{|l|l|l|l|}
\hline \multicolumn{2}{|l|}{ August 18, 1852} \\
\hline $\begin{array}{l}\text { Time: Unknown } \\
\text { Phenomenon Notes: None } \\
\text { Number of Observations: } 2\end{array}$ \\
\hline Longitude & Latitude & City & Description \\
\hline-72.3388 & 18.5432 & Port-au-Prince & $\begin{array}{l}\text { (Meriam, 1853): Aug. 18, Shock of Earthquake at Port au Prince and } \\
\text { Gonaives, St. Domingo. } \\
\text { (Perrey, 1856): August 18, 1852, at Port-au-Prince and Gonaives (St. } \\
\text { Domingue). }\end{array}$ \\
\hline
\end{tabular}




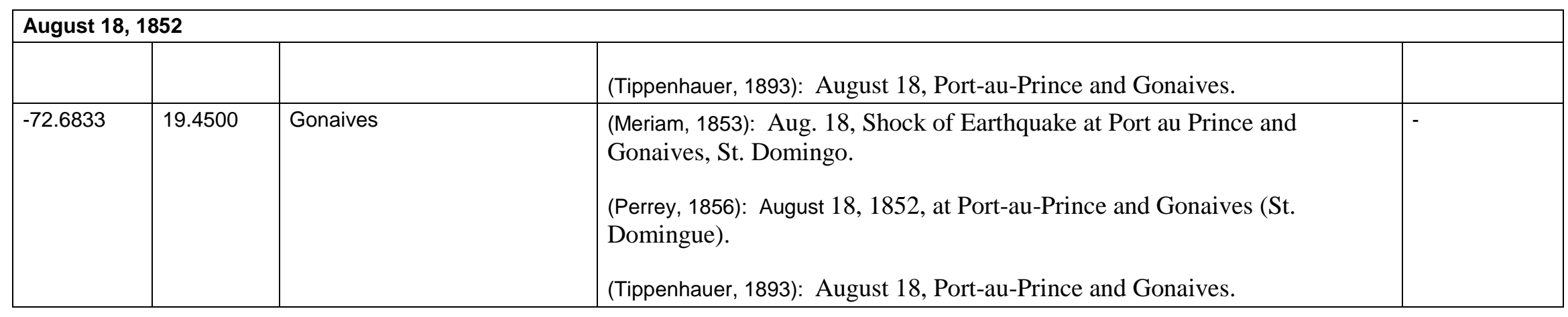

\section{August 19, 1852}

Time: $3: 00$ and 4:00 in the morning, Port-au-Prince local time

Phenomenon Notes: None

Number of Observations: 1

\begin{tabular}{|l|l|l|l|l|}
\hline Longitude & Latitude & City & Description \\
\hline-72.3388 & 18.5432 & Port-au-Prince & $\begin{array}{l}\text { (Meriam, 1853): Aug. 19, Two heavy shocks at Port au Prince - one at 3 and } \\
\text { one at 4 A.M. } \\
\text { (Perrey, 1856): August 19, 1852, at Port-au-Prince, two tremors, one at 3 } \\
\text { o'clock and the other 4 o'clock in the morning. }\end{array}$ \\
\hline
\end{tabular}

\begin{tabular}{|c|c|c|c|c|}
\hline \multicolumn{5}{|c|}{ August 28, 1852} \\
\hline \multicolumn{5}{|c|}{$\begin{array}{l}\text { Time: Unknown } \\
\text { Phenomenon Notes: Tippenhauer (1893) suggests it was on the 28th and 29th in his entry. } \\
\text { Number of Observations: } 1\end{array}$} \\
\hline Longitude & Latitude & City & Description & Intensity \\
\hline
\end{tabular}




\begin{tabular}{|c|c|c|c|c|}
\hline \multicolumn{5}{|c|}{ November 25, 1852} \\
\hline \multicolumn{5}{|c|}{$\begin{array}{l}\text { Time: At night, Port-au-Prince local time } \\
\text { Phenomenon Notes: None } \\
\text { Number of Observations: } 1\end{array}$} \\
\hline Longitude & Latitude & City & Description & Intensity \\
\hline-72.3388 & 18.5432 & Port-au-Prince & $\begin{array}{l}\text { (Meriam, 1853): Nov. 25, Severe shock of Earthquake at Port au Prince in the } \\
\text { night. } \\
\text { (Perrey, 1855): November 25, 1852, at night, at Port-au-Prince (Haiti), } \\
\text { violent tremor. } \\
\text { (Tippenhauer, 1893): November 25, night, Port-au-Prince. }\end{array}$ & - \\
\hline
\end{tabular}

\section{September 11, 1853}

Time: Unknown

Phenomenon Notes: None

Number of Observations: 1

\begin{tabular}{|l|l|l|l|l|}
\hline Longitude & Latitude & City & Description \\
\hline-72.3388 & 18.5432 & Port-au-Prince & (Perrey, 1855): September 11, 1853, in Port-au-Prince (Haiti). \\
& & & (Tippenhauer, 1893): September 11, Port-au-Prince. \\
\hline
\end{tabular}

\section{July 8, 1855}

Time: Early in the morning, Port-au-Prince local time

Phenomenon Notes: None

Number of Observations: 1

\begin{tabular}{|l|l|l|l|l|}
\hline Longitude & Latitude & City & Description \\
\hline-72.3388 & 18.5432 & Port-au-Prince & $\begin{array}{l}\text { (Perrey, 1857): July 8, 1855, very early in the morning, in Port-au-Prince and } \\
\text { its surroundings, slight tremors. }\end{array}$ \\
(Tippenhauer, 1893): July 8, morning, Port-au-Prince and surrounding area.
\end{tabular}

\section{August 26, 1855}

Time: 10:00 AM, Santo Domingo local time

Phenomenon Notes: None

Number of Observations: 1

\begin{tabular}{|l|l|l|}
\hline Longitude & Latitude & City \\
\hline
\end{tabular} 


\begin{tabular}{|l|l|l|l|l|}
\hline \multicolumn{2}{|l|}{ August 26, 1855 } & (Perrey, 1861): August 26, 10 h (sic), In Santo Domingo, earthquake without \\
\hline-69.8877 & 18.4722 & Santo Domingo & \\
& & & $\begin{array}{l}\text { (Tippenhauer, 1893): August 26, 1855, 10 o'clock, Santo Domingo. } \\
\text { (de Utrera, 1995): August 26, Santo Domingo. }\end{array}$ \\
\hline
\end{tabular}

\begin{tabular}{|c|c|c|c|c|}
\hline \multicolumn{5}{|c|}{ April 8, 1860} \\
\hline \multicolumn{5}{|c|}{$\begin{array}{l}\text { Time: 5:00 AM, Port-au-Prince local time (Easter) } \\
\text { Tsunami: A tsunami was observed in Anse-a-Veau and Miragoane (New York Times,1860b; Scherer, 1912a). } \\
\text { Phenomenon Notes: The shock at } 5 \text { in the morning could have been the foreshock to the stronger later one that occurred at } 10 \text { in the evening that day Port-au- } \\
\text { Prince local time, or } 9 \text { PM Gonaives local time. } \\
\text { Number of Observations: } 16\end{array}$} \\
\hline Longitude & Latitude & City & Description & Intensity \\
\hline-73.3447 & 18.5028 & Anse-A-Veau & $\begin{array}{l}\text { (New York Times, 1860b): In the town of Anse-a-Veau, in the south, } 124 \\
\text { houses were thrown down and a great many of their inmates severely } \\
\text { wounded. } \\
\text { (Perrey, 1862): The place called Anse-au-Veau appears to have been the } \\
\text { most abused. A hundred and twenty-four houses were damaged or } \\
\text { destroyed. } \\
\text { (Scherer, 1912a): At Anse à Veau one hundred twenty four houses were } \\
\text { destroyed or cracked. *** Crevasses running from north to south crossed } \\
\text { the streets. The sea drew back and then broke with a crash on the shore. The } \\
\text { people took refuge in La Haute Ville [uptown] which had suffered less. }\end{array}$ & 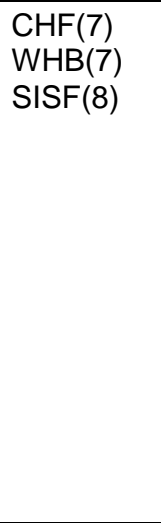 \\
\hline-72.8668 & 18.4315 & Petit Goave & $\begin{array}{l}\text { (Scherer, 1912a): At Petit Goave several houses with stone walls crumbled; } \\
\text { others half of wood and half of stone had their doors unhinged. One factory } \\
\text { was nearly destroyed. All the houses were abandoned. }\end{array}$ & $\begin{array}{l}\mathrm{CHF}(6) \\
\text { WHB(6) } \\
\operatorname{SISF}(7.5)\end{array}$ \\
\hline-72.8344 & 18.4395 & Mont Tapion & $\begin{array}{l}\text { (Scherer, 1912a): Rocks obstructed the highway. [This location is between Petit } \\
\text { Goave and Grande Goave and is an area prone to landslides and rock falls.] }\end{array}$ & $\begin{array}{l}\mathrm{CHF}(6) \\
\operatorname{WHB}(-)\end{array}$ \\
\hline
\end{tabular}




\begin{tabular}{|c|c|c|c|c|}
\hline \multicolumn{5}{|c|}{ April 8, 1860} \\
\hline-73.5079 & 18.5264 & Petit Trou de Nippes & $\begin{array}{l}\text { (Scherer, 1912a): At Petit Trou de Nippes and at Baradères the damage was } \\
\text { less [than at Miragoane]. }\end{array}$ & $\begin{array}{l}\mathrm{CHF}(5) \\
\text { WHB(5) } \\
\text { SISF(7) }\end{array}$ \\
\hline-73.6387 & 18.5432 & Baradères & $\begin{array}{l}\text { (Scherer, 1912a): At Petit Trou de Nippes and at Baradères the damage was } \\
\text { less [than at Miragoane]. }\end{array}$ & $\begin{array}{l}\text { CHF(5) } \\
\text { WHB(5) } \\
\text { SISF(7) }\end{array}$ \\
\hline-72.3388 & 18.5432 & Port-au-Prince & $\begin{array}{l}\text { (New York Times, 1860b): The earthquakes which I have stated were felt here } \\
\text { [Kingston] were also experienced in Hayti, where they occasioned serious } \\
\text { injury. The concussions were so great that the impression was that had the } \\
\text { undulations lasted a second longer it was probably that not a single house } \\
\text { would have been left standing at Port-au-Prince. There were repeated } \\
\text { convulsions, which threw the inhabitants into such a state of alarm and } \\
\text { excitement that they abandoned their houses, which they momentarily } \\
\text { expected to fall and cover them, and took up their abode in tents. } \\
\text { (Perrey, 1862): On the 8th, } 5 \text { o'clock in the morning in Port-au-Prince (Haiti), } \\
\text { a first shock was felt throughout the departments. The movements continued } \\
\text { until the 13th. We did not account it being said, that at least thirty shocks in } \\
\text { twenty-four hours. The largest was felt on the 8th between 10:00 and 10:30 } \\
\text { in the evening. } \\
\text { (Scherer, 1912a): At Port-au-Prince the shock at half-past ten at night caused } \\
\text { terror in all and the population fled into the streets from every quarter and } \\
\text { passed the night outdoors. Several houses were badly damaged and one not } \\
\text { yet finished was thrown down. From the 8th to the 11th of April twenty to } \\
\text { thirty shocks were felt. } \\
\text { (Taber, 1922): Towns *** as far east as Port-au-Prince had some houses } \\
\text { thrown or badly damaged. }\end{array}$ & $\begin{array}{l}\text { CHF(5) } \\
\text { WHB(5) } \\
\text { SISF(7) }\end{array}$ \\
\hline-73.3971 & 18.2816 & Aquin & $\begin{array}{l}\text { (Perrey, 1862): At Aquin, where they had not felt the one at } 5 \text { in the } \\
\text { morning, they were repeated for a quarter of an hour by quarter of an hour } \\
\text { after the one at 10:30 in the evening up until the 13th. Several houses were } \\
\text { damaged there. The length of the longest shock (the one others reported at } \\
10 \text { at night) did not exceed fifteen to twenty seconds. } \\
\text { (Scherer, 1912a): It again crossed the valley of L'Asile and made itself } \\
\text { strongly felt in the south at Aquin and at Cayes. Various houses were } \\
\text { seriously damaged. }\end{array}$ & $\begin{array}{l}\text { CHF(5) } \\
\text { WHB(5) } \\
\text { SISF(7) }\end{array}$ \\
\hline
\end{tabular}




\begin{tabular}{|c|c|c|c|c|}
\hline \multicolumn{5}{|c|}{ April 8, 1860} \\
\hline-73.7500 & 18.1945 & Les Cayes & $\begin{array}{l}\text { (Perrey, 1862): In Les Cayes, they did not report the two strong tremors, the } \\
\text { 8th, at } 5 \text { o'clock in the morning, and } 10 \text { o'clock at night. The walls were } \\
\text { cracked. } \\
\text { (Scherer, 1912a): It again crossed the valley of L'Asile and made itself } \\
\text { strongly felt in the south at Aquin and at Cayes. Various houses were } \\
\text { seriously damaged. }\end{array}$ & $\begin{array}{l}\mathrm{CHF}(5) \\
\text { WHB(5) } \\
\text { SISF(7) }\end{array}$ \\
\hline-72.5167 & 18.2333 & Jacmel & $\begin{array}{l}\text { (Scherer, 1912a): It caused a flurry in Port-au-Prince, Jacmel, Leogane, and } \\
\text { St. Marc. Moreover, people were impressed after that by the least shock. } \\
\text { (Taber, 1922): Towns } * * * \text { as far east as Port-au-Prince had some houses } \\
\text { thrown or badly damaged. }\end{array}$ & $\begin{array}{l}\text { CHF(5) } \\
\text { WHB(-) } \\
\text { SISF(7) }\end{array}$ \\
\hline-72.6333 & 18.5167 & Leogane & $\begin{array}{l}\text { (Scherer, 1912a): It caused a flurry in Port-au-Prince, Jacmel, Leogane, and } \\
\text { St. Marc. Moreover, people were impressed after that by the least shock. } \\
\text { (Taber, 1922): Towns *** as far east as Port-au-Prince had some houses } \\
\text { thrown or badly damaged. }\end{array}$ & $\begin{array}{l}\text { CHF(5) } \\
\text { WHB(-) } \\
\text { SISF(7) }\end{array}$ \\
\hline-73.9277 & 18.0938 & Port Salud & (Scherer, 1912a): The shock was further strongly felt at Port Salud. & $\begin{array}{l}\text { CHF(4) } \\
\text { WHB(4) } \\
\text { SISF(6) }\end{array}$ \\
\hline-72.2006 & 19.7616 & Cap Haitien & $\begin{array}{l}\text { (New York Times, 1860a): Cape Haytien [Cap Haitien] reports no loss of life, } \\
\text { although several walls and a few houses fell. }\end{array}$ & $\begin{array}{l}\text { CHF(-) } \\
\text { WHB(-) }\end{array}$ \\
\hline-72.6833 & 19.4500 & Gonaives & $\begin{array}{l}\text { (New York Times, 1860a): By the kindness of Capt. J.R. Lavender, of the brig. } \\
\text { Foster, we have been enabled to examine correspondence from Gonaives, } \\
\text { giving an account of a series of earthquakes which startled the inhabitants of } \\
\text { the island of Hayti from the 8th to the 13th of April, when the brig left port. } \\
\text { The first shock was a heavy one, and occurred on the morning of Sunday } \\
\text { April 8. } * * \text { Capt. Lavender says the first shock was very perceptible } \\
\text { among the shipping, causing a trembling sensation and a sound similar to } \\
\text { the rumbling of chain cables over a rocky bottom. *** The only damage } \\
\text { was the cracking of a few walls: but when the brig left the excitement }\end{array}$ & $\begin{array}{l}\text { CHF(3) } \\
\text { WHB(-) } \\
\text { SISF(5) }\end{array}$ \\
\hline
\end{tabular}




\begin{tabular}{|l|l|l|l|}
\hline April 8, 1860 & & $\begin{array}{l}\text { continued. *** The first motion perceived by the correspondent at } \\
\text { Gonaives, on the morning of the 8th, was a slight undulation of the earth, } \\
\text { apparently from South to North, then a cracking and creaking sound in all } \\
\text { the timbers of the house; and finally a jumping or heaving motion of the } \\
\text { whole building, as if the ground were alternately raised and depressed, } \\
\text { creating a very unpleasant sensation. } \\
\text { (Perrey, 1862): On the 8, at dawn and at 9 o'clock in the evening in Gonaives } \\
\text { (Haiti), two violent tremors. }\end{array}$ \\
\hline-76.7929 & 17.9711 & Kingston, Jamaica & $\begin{array}{l}\text { (New York Times, 1860b): Correspondence of the New York times: Kingston } \\
\text { (Jamaica) Friday April 20, 1860 - * * Several slight shocks of earthquake } \\
\text { were left in this island during the past fortnight. As I explain elsewhere, } \\
\text { these same convulsions occasioned very serious damage in Hayti. }\end{array}$ \\
\hline
\end{tabular}

\begin{tabular}{|c|c|c|c|c|}
\hline \multicolumn{5}{|c|}{ April 9, 1860 to May 5, 1860} \\
\hline \multicolumn{5}{|c|}{$\begin{array}{l}\text { Time: Various } \\
\text { Phenomenon Notes: Aftershocks of April 8, } 1860 . \\
\text { Number of Observations: } 4\end{array}$} \\
\hline Longitude & Latitude & City & Description & Intensity \\
\hline-72.3388 & 18.5432 & Port-au-Prince & $\begin{array}{l}\text { (Perrey, 1862): On the 9th at midnight, and on the next morning, at Port-au- } \\
\text { Prince, many tremors. On the } 10 \text { and the 12, at Port-au-Prince, new tremors. }\end{array}$ & - \\
\hline-72.6833 & 19.4500 & Gonaives & $\begin{array}{l}\text { (The New York Times, 1860a): During the night of the 11th the shocks were } \\
\text { very frequent, but on the 12th and 13th there were but two shocks. } \\
\text { (Perrey, 1862): The same day [April 9] hours not indicated, at Gonaives, two } \\
\text { light tremors. }\end{array}$ & - \\
\hline-75.8296 & 20.0209 & Santiago, Cuba & $\begin{array}{l}\text { (Perrey, 1862): On the 9th, again, in the morning, at Santiago, Cuba, one } \\
\text { strong tremor. }\end{array}$ & - \\
\hline- & - & Haiti (island) & $\begin{array}{l}\text { (Perrey, 1862): As of the 16th, the Travail, Haitien newspaper, we burrow } \\
\text { the following details, "It has been three days we have been at rest.” } \\
\text { According to a letter I received from Mr. Ardouin, Minister of Haiti in } \\
\text { Paris, the shocks were reported for fifteen days. They were felt as far as } \\
\text { Jamaica, Cuba, and in the north up to the island of New Providence } \\
\text { [Bahamas]. The same day (times not indicated) at Inagua [Bahamas], two } \\
\text { violent shocks, but without damages. }\end{array}$ & - \\
\hline
\end{tabular}




\begin{tabular}{|l|l|l|}
\hline April 9, 1860 to May 5, 1860 & $\begin{array}{l}\text { (Perrey, 1873): April - the 8 to May 5, in Haiti, continuous tremors that were } \\
\text { reported in great part by M. A. Lancaster...On the 8th at 4h. 20 m. in the } \\
\text { morning, strong tremor, a second one at 6 o'clock. Both were accompanied } \\
\text { by a loud noise. The 9th, ten tremors. The 10th, at 10 o'clock at night and at } \\
\text { midnight, then on the 11th, almost at every hour new tremors. Until the } \\
\text { 29th, they are almost daily. In all sixty-eight tremors from south-southwest } \\
\text { to north-northeast, without counting the vibrations. }\end{array}$ \\
\hline
\end{tabular}

\begin{tabular}{|c|c|c|c|c|}
\hline \multicolumn{5}{|c|}{ December 1, 1860} \\
\hline \multicolumn{5}{|c|}{$\begin{array}{l}\text { Time: Unknown } \\
\text { Phenomenon Notes: None } \\
\text { Number of Observations: } 1\end{array}$} \\
\hline Longitude & Latitude & City & Description & Intensity \\
\hline-69.8877 & 18.4722 & Santo Domingo & $\begin{array}{l}\text { (Perrey, 1862): 1860, On the first day of the month (December) at Saint- } \\
\text { Domingue, many tremors more or less strong. (Letter from M. B. Ardouin, } \\
\text { minister of Haiti, close to the French government). }\end{array}$ & - \\
\hline
\end{tabular}

\section{April 8, 1861}

Time: Unknown

Phenomenon Notes: None

Number of Observations: 1

\begin{tabular}{|l|l|l|l|l|}
\hline Longitude & Latitude & City & Description & Intensity \\
\hline-72.2006 & 19.7616 & Cap Haitien & (Tippenhauer, 1893): 1861, April 8 - Cap Haitien. \\
\hline
\end{tabular}

\section{August 22, 1863}

\section{Time: Unknown}

Phenomenon Notes: Sounds were heard before the arrival of the shaking (Perrey, 1865).

Number of Observations: 1

\begin{tabular}{|l|l|l|l|l|}
\hline Longitude & Latitude & City & Description \\
\hline-72.3388 & 18.5432 & Port-au-Prince & $\begin{array}{l}\text { (Perrey, 1865): 1863, August 22, 9h 54 m. 36s. mean local time, at Port-au- } \\
\text { Prince (Haiti), one undulatory tremor, preceded by a subterranean noise like } \\
\text { in years before. Trustworthy people heard an underground detonation like a } \\
\text { cannon shot, others clearly heard a loud roll, the two descriptions may exist } \\
\text { at the same time, given the different terrains on which the city is built. } \\
\text { (Moniteur Haitien of August 29. Comm. of M. Ardouin, minister of Haitien } \\
\text { government in Paris). }\end{array}$ \\
\hline
\end{tabular}




\begin{tabular}{|c|c|c|c|c|}
\hline \multicolumn{5}{|c|}{ February 17, 1864} \\
\hline \multicolumn{5}{|c|}{$\begin{array}{l}\text { Time: Unknown } \\
\text { Phenomenon Notes: None } \\
\text { Number of Observations: } 1\end{array}$} \\
\hline Longitude & Latitude & City & Description & Intensity \\
\hline-72.3388 & 18.5432 & Port-au-Prince & (Tippenhauer, 1893): 1864, February 17, Port-au-Prince. & - \\
\hline
\end{tabular}

\begin{tabular}{|l|l|l|l|}
\hline \multicolumn{4}{|l|}{ April 20, 1864} \\
\hline $\begin{array}{l}\text { Time: Unknown } \\
\text { Phenomenon Notes: None } \\
\text { Number of Observations: } 1\end{array}$ \\
\hline Longitude & Latitude & City & Description \\
\hline-72.3388 & 18.5432 & Port-au-Prince & (Tippenhauer, 1893): 1864, April 20 - Port-au-Prince, 3 shocks. \\
\hline
\end{tabular}

\section{May 19, 1864}

Time: Unknown

Phenomenon Notes: Two tremors occurred on this day, the second weaker than the first.

Number of Observations: 1

\begin{tabular}{|l|l|l|l|l|}
\hline Longitude & Latitude & City & Description \\
\hline-72.5167 & 18.2333 & Jacmel & $\begin{array}{l}\text { (Perrey, 1866): 1864, May, 19: Jacmel (Haiti), violent earthquake felt in the } \\
\text { port by the schooner George Prescott; It has destroyed many houses on the } \\
\text { coast. An hour later, a second weaker tremor. }\end{array}$ \\
\hline
\end{tabular}

\section{May 21, 1864}

Time: Unknown

Phenomenon Notes: Aftershock of May 19, 1864

Number of Observations: 1

\begin{tabular}{|l|l|l|l|l|}
\hline Longitude & Latitude & City & Description \\
\hline-72.5167 & 18.2333 & Jacmel & (Perrey, 1866): 1864, May 21, third tremor, that again knocked down houses. & - \\
\hline
\end{tabular}

\section{June 1, 1864}

Time: Unknown

Phenomenon Notes: Possible aftershock of May 19, 1864 (?).

Number of Observations: 1

\begin{tabular}{l|l|l|}
\hline Longitude & Latitude & City \\
\hline
\end{tabular} 


\section{June 1, 1864}

\begin{tabular}{|l|l|l|l|l|}
\hline-72.5167 & 18.2333 & Jacmel & (Perrey, 1866): 1864, June 1: Jacmel (Haiti), a fourth tremor. No accidents. & - \\
\hline
\end{tabular}

\section{February 14, 1866 \\ Time: Unknown}

Phenomenon Notes: None

Number of Observations: 1

\begin{tabular}{|l|l|l|l|l|}
\hline Longitude & Latitude & City & Description & Intensity \\
\hline-69.8877 & 18.4722 & Santo Domingo & $\begin{array}{l}\text { (Perrey, 1870): The same day [February 14, 1866] hour not indicated, at Santo } \\
\text { Domingo, one strong tremor; many houses knocked down or damaged. }\end{array}$ & $\begin{array}{l}\text { CHF(5) } \\
\text { SISF(7) }\end{array}$ \\
\hline
\end{tabular}

\begin{tabular}{|c|c|c|c|c|}
\hline \multicolumn{5}{|c|}{ December 1867 to January 1868} \\
\hline \multicolumn{5}{|c|}{$\begin{array}{l}\text { Time: Unknown } \\
\text { Phenomenon Notes: Multiple events occurring from December to January. } \\
\text { Number of Observations: } 1\end{array}$} \\
\hline Longitude & Latitude & City & Description & Intensity \\
\hline-69.8877 & 18.4722 & Santo Domingo & $\begin{array}{l}\text { (Perrey, 1872a): } 1868 \text { January } 17 \text { and 18, at the island of Haiti, tremors } \\
\text { (M.W. Mallet.) "In January", said M. Dr. Rojas, "the earthquakes were } \\
\text { frequent in Cuba and in Santo Domingo, which are influenced by the } \\
\text { volcanic axis of Central America. New earthquakes shake the Lesser } \\
\text { Antilles which seem to rest after the earthquakes of November and } \\
\text { December, and the seismic waves, leaving the island group south of the } \\
\text { Virgin Islands, takes its direction to the NW. (L.C. p.47)". } \\
\text { (de Utrera, 1995): } 1867 \text { - End of the year to New Year's; Santo Domingo. }\end{array}$ & - \\
\hline
\end{tabular}

\begin{tabular}{|l|l|l|l|}
\hline \multicolumn{4}{|l|}{ August, 1878} \\
\hline $\begin{array}{l}\text { Time: Unknown } \\
\text { Phenomenon Notes: None } \\
\text { Number of Observations: } 1\end{array}$ \\
\hline Longitude & Latitude & City & Description \\
\hline-72.3388 & 18.5432 & Port-au-Prince & $\begin{array}{l}\text { (Tippenhauer, 1893): 1878, August, Port-au-Prince - several days weak } \\
\text { shake. }\end{array}$ \\
\hline
\end{tabular}




\begin{tabular}{|c|c|c|c|c|}
\hline \multicolumn{5}{|c|}{ August 19, 1881} \\
\hline \multicolumn{5}{|c|}{$\begin{array}{l}\text { Time: 8:00 AM, Higuey local time } \\
\text { Phenomenon Notes: Some sources use the year 1882, instead of } 1881 \text { see Higuey entry. } \\
\text { Number of Observations: } 3\end{array}$} \\
\hline Longitude & Latitude & City & Description & Intensity \\
\hline-68.7168 & 18.6154 & Higuey & $\begin{array}{l}\text { (de Utrera, 1995): } 1881 \text { August 19, one tremor at } 8 \text { AM; another at 8:30 } \\
\text { approximately, followed by a third. The sanctuary at Higuey very damaged. } \\
\text { The catalog [Scherer and Baltenweck, 1914] does not record this event on this } \\
\text { date. Instead it records as event in 1882. However the date we provide here } \\
\text { comes from the official correspondence by the priest in Higuey Francisco } \\
\text { Ciccone to the priesthood. } \\
\text { (Scherer, 1912a): In } 1882 \text { a slight shock was felt at Santo Domingo, Seybo } \\
\text { and Higuey. The churches of the two last places were damaged. }\end{array}$ & $\begin{array}{l}\mathrm{CHF}(6) \\
\text { SISF(7) } \\
\text { T\&R1977(6) }\end{array}$ \\
\hline-69.0364 & 18.7648 & Seibo & $\begin{array}{l}\text { (Scherer, 1912a): In } 1882 \text { a slight shock was felt at Santo Domingo, Seybo } \\
\text { and Higuey. The churches of the two last places were damaged. }\end{array}$ & $\begin{array}{l}\text { CHF(5) } \\
\text { SISF(7) } \\
\text { T\&R1977(7) }\end{array}$ \\
\hline-69.8877 & 18.4722 & Santo Domingo & $\begin{array}{l}\text { (Scherer, 1912a): In } 1882 \text { a slight shock was felt at Santo Domingo, Seybo } \\
\text { and Higuey. The churches of the two last places were damaged. }\end{array}$ & $\begin{array}{l}\text { CHF(3) } \\
\text { T\&R1977(3) }\end{array}$ \\
\hline
\end{tabular}

\section{September 15, 1884}

Time: 2:30 AM, Port-au-Prince local time

Phenomenon Notes: None

Number of Observations: 1

\begin{tabular}{|l|l|l|l|l|}
\hline Longitude & Latitude & City & Description \\
\hline-72.3388 & 18.5432 & Port-au-Prince & $\begin{array}{l}\text { (Tippenhauer, 1893): 1884 September 15 2:30 early, weakly. } \\
\text { (Scherer and Baltenweck, 1914): September 15 at 2:30 a.m. Port-au-Prince, } \\
\text { weak tremor. }\end{array}$ \\
\hline
\end{tabular}

\section{October, 1886}

Time: Around noon, Port-au-Prince local time

Phenomenon Notes: None

Number of Observations: 2

\begin{tabular}{|l|l|l|l|l|}
\hline Longitude & Latitude & City & Description \\
\hline-72.3388 & 18.5432 & Port-au-Prince & $\begin{array}{l}\text { (Tippenhauer, 1893): 1886 October (?) 12 midday Gonaives and Port-au- } \\
\text { Prince, 1 weak tremor. }\end{array}$ \\
\hline
\end{tabular}




\begin{tabular}{|c|c|c|c|c|}
\hline \multicolumn{5}{|c|}{ October, 1886} \\
\hline-72.6833 & 19.4500 & Gonaives & $\begin{array}{l}\text { (Tippenhauer, 1893): } 1886 \text { October (?) } 12 \text { midday Gonaives and Port-au- } \\
\text { Prince, } 1 \text { weak tremor. } \\
\text { (Scherer and Baltenweck, 1914): October at noon, Gonaives. }\end{array}$ & - \\
\hline
\end{tabular}

\begin{tabular}{|l|l|l|l|l|}
\hline \multicolumn{2}{|l|}{ January, $\mathbf{1 8 8 7}$} \\
\hline $\begin{array}{l}\text { Time: Unknown } \\
\text { Phenomenon Notes: None } \\
\text { Number of Observations: } 1\end{array}$ \\
\hline Longitude & Latitude & City & Description \\
\hline-74.1145 & 18.6446 & Jeremie & (Tippenhauer, 1893): 1887, early, Jeremie. \\
& & & (Scherer and Baltenweck, 1914): January, Jeremie. \\
\hline
\end{tabular}

\section{September 15, 1887}

Time: 8:15 PM, Port-au-Prince local time

Phenomenon Notes: None

Number of Observations: 1

\begin{tabular}{|l|l|l|l|l|}
\hline Longitude & Latitude & City & Description \\
\hline-72.3388 & 18.5432 & Port-au-Prince & $\begin{array}{l}\text { (Tippenhauer, 1893): 1887 September 15, 8:15 evening, Port-au-Prince, } \\
\text { weak. }\end{array}$ & - \\
\hline
\end{tabular}

\section{September 22, 1887}

Time: 4:50 AM, Port-au-Prince local time

Phenomenon Notes: Possible foreshock (?)

Number of Observations: 1

\begin{tabular}{|l|l|l|l|l|}
\hline Longitude & Latitude & City & Description \\
\hline-72.3388 & 18.5432 & Port-au-Prince & $\begin{array}{l}\text { (Tippenhauer, 1893): 1887 September 22, 4:50 morning, lasting 2 seconds, E } \\
\text { to W, Port-au-Prince. }\end{array}$ \\
& $\begin{array}{l}\text { (Scherer and Baltenweck, 1914): September 22 at 5:00 a.m. Port-au-Prince. } \\
\text { Direction NE, duration 5 seconds. }\end{array}$ \\
\hline
\end{tabular}

\section{September 23, 1887}

Time: 12:50 AM, Port-au-Prince local time

Phenomenon Notes: Possible foreshock (?) 


\begin{tabular}{|l|l|l|l|l|}
\hline \multicolumn{2}{|l|}{ September 23, 1887} \\
\hline Lumber of Observations: 1 \\
\hline-72.3388 & 18.5432 & Port-au-Prince & Description \\
\hline & & $\begin{array}{l}\text { (Tippenhauer, 1893): 1887 September 23, 12:50 night, Port-au-Prince. } \\
\text { (Scherer and Baltenweck, 1914): September 23 at 55 after midnight, Port-au- } \\
\text { Prince, one shock. }\end{array}$ \\
\hline
\end{tabular}

\begin{tabular}{|c|c|c|c|c|}
\hline \multicolumn{5}{|c|}{ September 23, 1887} \\
\hline \multicolumn{5}{|c|}{$\begin{array}{l}\text { Time: 6:43 AM Kingston, Jamaica local time } \\
\text { Tsunami: According to Scherer (1912a) there was a tsunami associated with this earthquake that affected from Mole-St. Nicolas to Anse d'Hainault; on the western } \\
\text { most coastline in the southern peninsula of Haiti, north of Tiburon. } \\
\text { Phenomenon Notes: Recorded in Kingston Jamaica (Hall, 1922). Many Spanish newspapers republished the same story that came out in The New York Times } \\
\text { (1887a). } \\
\text { Number of Observations: } 22\end{array}$} \\
\hline Longitude & Latitude & City & Description & Intensity \\
\hline-72.8370 & 19.9408 & Port-de-Paix & $\begin{array}{l}\text { (Tippenhauer, 1893): 7:00 early one house completely destroyed, several } \\
\text { damaged, the church under construction was destroyed. } \\
\text { (Scherer, 1912a): At Port de Paix the church recently erected was struck } \\
\text { down, several houses were overthrown and others of brick badly damaged. } \\
\text { (de Utrera, 1995): Considerable damages in Haiti, with almost complete } \\
\text { destruction of Cape Haitien, Port-de-Paix, and Mole St. Nicolas. } \\
\text { (Shepherd and Lynch, } 1992 \text { quoting, Colonial Office Records): The city is } \\
\text { reported to have been partly destroyed. }\end{array}$ & $\begin{array}{l}\text { CHF(7) } \\
\text { WHB(7) } \\
\text { SISF(8) } \\
\text { S\&L1992(8) }\end{array}$ \\
\hline
\end{tabular}




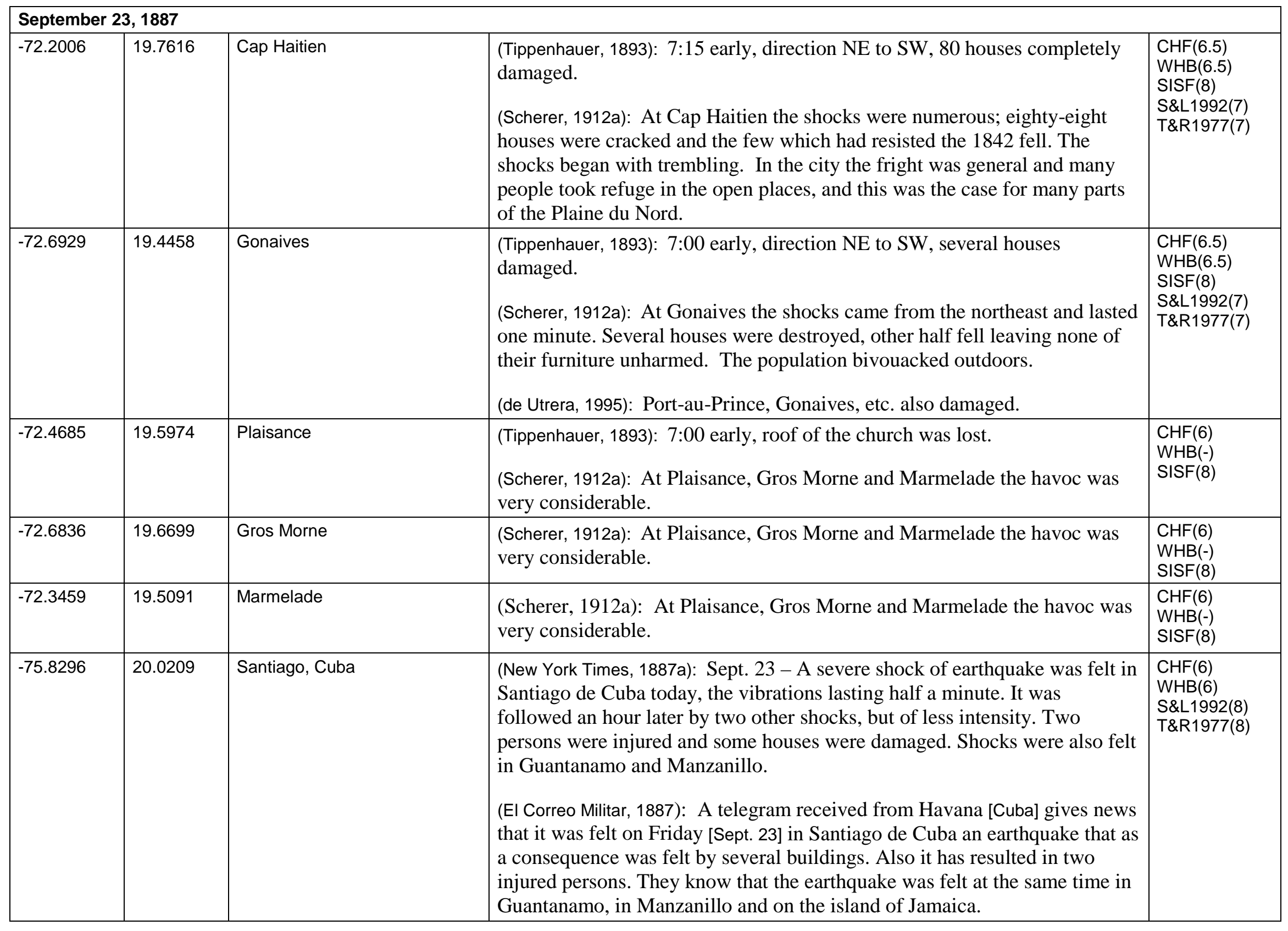




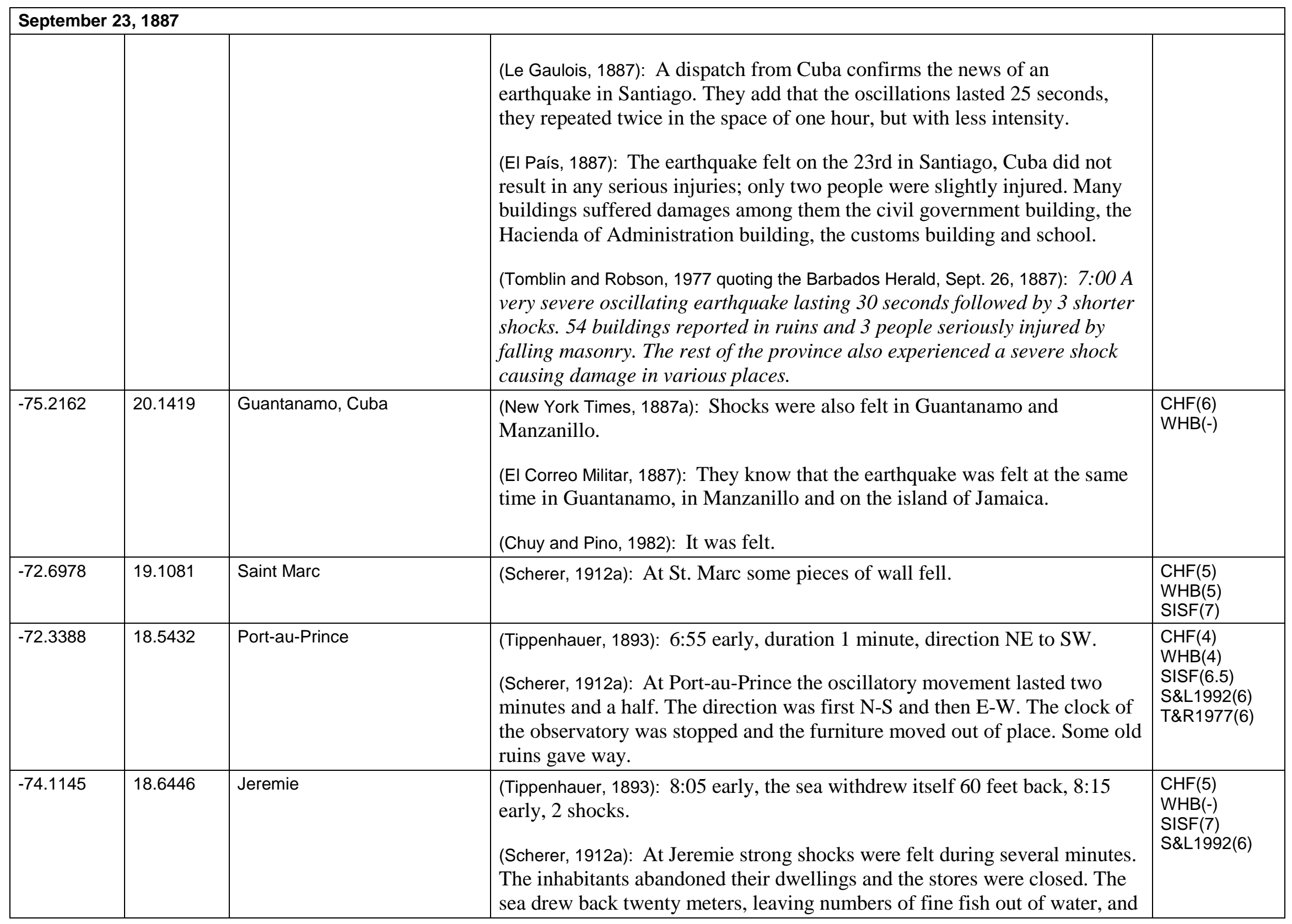




\begin{tabular}{|c|c|c|c|c|}
\hline \multicolumn{5}{|c|}{ September 23, 1887} \\
\hline & & & $\begin{array}{l}\text { the people were still disputing about these, when the water returned with a } \\
\text { rush upon the beach. There was no accident however. The same movement } \\
\text { of the sea made itself felt in all the neighborhood ports and especially at } \\
\text { Anse d'Hainault. }\end{array}$ & \\
\hline-73.7500 & 18.1945 & Les Cayes & $\begin{array}{l}\text { (Tippenhauer, 1893): 7:50 early, duration } 15 \text { minutes. } \\
\text { (Scherer, 1912a): At Cayes the earthquake lasted several minutes. Some old } \\
\text { buildings were thrown down and others were badly damaged. }\end{array}$ & $\begin{array}{l}\text { CHF(5) } \\
\text { WHB(5) } \\
\text { SISF(7) }\end{array}$ \\
\hline-73.3971 & 18.2816 & Aquin & $\begin{array}{l}\text { (Scherer, 1912a): At Aquin and Jacmel shocks lasted only a few minutes } \\
\text { without doing any harm. }\end{array}$ & $\begin{array}{l}\text { CHF(4) } \\
\text { WHB(4) } \\
\text { SISF(5) }\end{array}$ \\
\hline-73.6742 & 20.9335 & Great Inagua, Bahamas & $\begin{array}{l}\text { (Montadon, 1962): With one strong reverberation on the island of Inagua, } \\
\text { Bahamas. } \\
\text { (Shepherd and Lynch, 1992): Strong shaking, the lighthouse keeper at Inagua } \\
\text { reported a very severe shock. }\end{array}$ & $\begin{array}{l}\text { CHF(4) } \\
\text { WHB(4) } \\
\text { S\&L1992(7) }\end{array}$ \\
\hline-77.1199 & 20.3457 & Manzanillo, Cuba & $\begin{array}{l}\text { (New York Times, 1887a): Shocks were also felt in Guantanamo and } \\
\text { Manzanillo. } \\
\text { (El Correo Militar, Sept. 26, 1887): They know that the earthquake was felt at } \\
\text { the same time in Guantanamo, in Manzanillo and on the island of Jamaica. } \\
\text { (Chuy and Pino, 1982): It was felt. }\end{array}$ & $\begin{array}{l}\mathrm{CHF}(3) \\
\mathrm{WHB}(3)\end{array}$ \\
\hline-76.2579 & 20.8854 & Holguin, Cuba & (Shepherd and Lynch, 1992 quoting Chuy, 1980): Felt. & $\begin{array}{l}\mathrm{CHF}(3) \\
\text { WHB(3) }\end{array}$ \\
\hline-76.6501 & 20.3734 & Bayamon, Cuba & (Chuy and Pino, 1982): It was felt. & $\begin{array}{l}\mathrm{CHF}(3) \\
\mathrm{WHB}(3) \\
\end{array}$ \\
\hline-76.6742 & 20.9335 & Cristo Cautu, Cuba & (Chuy and Pino, 1982): It was felt. & $\begin{array}{l}\mathrm{CHF}(3) \\
\mathrm{WHB}(3)\end{array}$ \\
\hline
\end{tabular}




\begin{tabular}{|l|l|l|l|l|}
\hline \multicolumn{2}{|l|}{ September 23, 1887 } & & in Hayti. \\
& & & $\begin{array}{l}\text { (Tomblin and Robson, 1977 quoting Colonial Standard and Jamaica Dispatch, Sept. } \\
\text { 23, 1887): An earthquake of unusual duration. Oscillations North to South. } \\
\text { The shocks were not of equal severity to those of previous similar } \\
\text { visitations. }\end{array}$ \\
\hline-69.8877 & 18.4722 & Santo Domingo & $\begin{array}{l}\text { (Scherer, 1912a): On the contrary at Santo Domingo there was much } \\
\text { damage. }\end{array}$ & \\
& & & & $\begin{array}{l}\text { CHF(3) } \\
\text { WHB(-) } \\
\text { SISF(6) } \\
\text { T\&R1977(7) }\end{array}$ \\
\hline
\end{tabular}

\begin{tabular}{|c|c|c|c|c|}
\hline \multicolumn{5}{|c|}{ September 23,1887 , to October 4,1887} \\
\hline \multicolumn{5}{|c|}{$\begin{array}{l}\text { Time: Various } \\
\text { Phenomenon Notes: Aftershocks of September 23, } 1887 . \\
\text { Number of Observations: } 7\end{array}$} \\
\hline Longitude & Latitude & City & Description & Intensity \\
\hline-75.8296 & 20.0209 & Santiago, Cuba & $\begin{array}{l}\text { (Le Gaulois, 1887): They add that the oscillations lasted } 25 \text { seconds, they } \\
\text { repeated twice in the space of one hour, but with less intensity. } \\
\text { (El Siglo Futuro, 1887): Telegram from Santiago, Cuba October 4, - } \\
\text { Trepidations tremors, fast and repetitive at nine in the morning today. As a } \\
\text { result, sinister prognostications were circulated alarming the public } \\
\text { permanently and paralyzing businesses. } \\
\text { (Tomblin and Robson, } 1977 \text { quoting Barbados Herald, Oct. 6, 1887): October 4, } \\
\text { 1887, 9:45 - severe shocks. Shocks of more or less severity have occurred } \\
\text { since the earthquake of September 23. 9:55 A slighter shock. }\end{array}$ & - \\
\hline-72.2006 & 19.7616 & Cap Haitien & (Tippenhauer, 1893): Sept 23, 8:45 evening, 2 shocks. & - \\
\hline-74.1145 & 18.6446 & Jeremie & (Tippenhauer, 1893): 1887, Sept. 24, $12: 30$ at night 3 shocks. & - \\
\hline-72.0683 & 18.2398 & Sale-Trou & (Tippenhauer, 1893): 1887, Sept 23, 8:03 evening, duration 2 minutes, & - \\
\hline
\end{tabular}




\begin{tabular}{|l|l|l|l|l|}
\hline \multicolumn{2}{|l|}{ September 23, 1887, to October 4, $\mathbf{1 8 8 7}$} & direction E to W. \\
\hline-75.0128 & 18.4018 & Navassa Island & $\begin{array}{l}\text { (New York Times, 1887b): Shaken by an earthquake. The steamer Alene, } \\
\text { which arrived from Savanilla last night, touched at Navassa on the way } \\
\text { here. There the officers were told that on Sept. 25 a severe shock of } \\
\text { earthquake had caused the island to sway to and fro for at least five minutes. } \\
\text { No damage however was done. }\end{array}$ \\
\hline- & - & Hispaniola & $\begin{array}{l}\text { (Milne, 1912): 1887, Sept. 23, 7h. A.M. also 9h. 10m. AM also Sept. 24 - 26. } \\
\text { West Indies, Bahamas, Inagua Island, Haiti, Port-de-Paix. }\end{array}$ \\
\hline
\end{tabular}

\begin{tabular}{|c|c|c|c|c|}
\hline \multicolumn{5}{|c|}{ March 28, 1889} \\
\hline \multicolumn{5}{|c|}{$\begin{array}{l}\text { Time: } 12: 59 \text { AM, Port-au-Prince local time } \\
\text { Phenomenon Notes: None } \\
\text { Number of Observations: } 2\end{array}$} \\
\hline Longitude & Latitude & City & Description & Intensity \\
\hline-72.3388 & 18.5432 & Port-au-Prince & $\begin{array}{l}\text { (Tippenhauer, 1893): } 1889 \text {, March 28, } 12: 59 \text { early, } 40 \text { seconds duration, ESE } \\
\text { to WNW direction, } 2 \text { shocks. } \\
\text { (Scherer and Baltenweck, 1914): March } 28 \text { at } 59 \text { minutes after midnight, Port- } \\
\text { au-Prince, } 2 \text { shocks, the first oscillation ESE, the second vibration lasted } 40 \\
\text { seconds total. }\end{array}$ & - \\
\hline-72.8668 & 18.4315 & Petit Goave & $\begin{array}{l}\text { (Tippenhauer, 1893): 1889, March } 28 \text { 1:05 early, } 40 \text { seconds duration, ESE - } \\
\text { WNW direction, } 2 \text { shocks. } \\
\text { (Scherer and Baltenweck, 1914): March } 28 \text { at 1:05 a.m., Petit Goave, } 2 \text { shocks, } \\
\text { direction ENE, duration } 40 \text { seconds. }\end{array}$ & - \\
\hline
\end{tabular}

\section{November 6, 1889}

Time: 6:00 PM, Port-au-Prince local time

Phenomenon Notes: None

Number of Observations: 1

\begin{tabular}{|l|l|l|l|l|}
\hline Longitude & Latitude & City & Description \\
\hline-72.3388 & 18.5432 & Port-au-Prince & $\begin{array}{l}\text { (Tippenhauer, 1893): 1889, November 6, 6:00 evening, 3 seconds duration, 1 } \\
\text { weak shock. } \\
\text { (Scherer and Baltenweck, 1914): November 6 at 6:00 p.m. Port-au-Prince, } \\
\text { duration 3 seconds. }\end{array}$ \\
\hline
\end{tabular}




\section{March 13, 1890}

Time: 8:45 AM, Port-au-Prince local time

Phenomenon Notes: None

Number of Observations: 1

\begin{tabular}{|l|l|l|l|l|}
\hline Longitude & Latitude & City & Description & Intensity \\
\hline-72.3388 & 18.5432 & Port-au-Prince & $\begin{array}{l}\text { (Tippenhauer, 1893): 1890, March 13, 8:45 early, 10 seconds duration, SW to } \\
\text { NE? , 1 fairly strong shock. }\end{array}$ \\
\hline
\end{tabular}

\section{July 3, 1890}

Time: Before 11 (AM/PM?) Jacmel local time

Phenomenon Notes: Tippenhauer (1893) does not clarify if it was at 11 AM or 11 PM.

Number of Observations: 1

\begin{tabular}{|l|l|l|l|l|}
\hline Longitude & Latitude & City & Description & Intensity \\
\hline-72.5167 & 18.2333 & Jacmel & (Tippenhauer, 1893): 1890, before July 3, before 11, 3 shocks. & -
\end{tabular}

\section{July (late), 1890}

Time: Unknown

Phenomenon Notes: None

Number of Observations: 1

\begin{tabular}{|l|l|l|l|l|}
\hline Longitude & Latitude & City & Description & Intensity \\
\hline-73.7500 & 18.1945 & Les Cayes & (Tippenhauer, 1893): 1890, end of July (?), several shocks. \\
\hline
\end{tabular}

\section{August 15, 1890}

Time: 1:27 AM, Port-au-Prince local time

Phenomenon Notes: None

Number of Observations: 1

\begin{tabular}{|l|l|l|l|l|}
\hline Longitude & Latitude & City & Description & Intensity \\
\hline-72.3388 & 18.5432 & Port-au-Prince & $\begin{array}{l}\text { (Tippenhauer, 1893): 1890, August 15, 1:27 early, 5 seconds duration, E - W, } \\
\text { 2 shocks moderately strong. }\end{array}$
\end{tabular}

\section{October 29, 1897}

Time: 09:33:34 PM Port-au-Prince local mean time (02:22:55 UTC, October 30, 1897)

Phenomenon Notes: The observatory in Port-au-Prince finally aquires precise clocks to calculate the local mean time that was $+04: 49: 21$ of Greenwich time.

Number of Observations: 1

Longitude Latitude City

Description

Intensity 


\begin{tabular}{|l|l|l|l|}
\hline \multicolumn{2}{|l|}{ October 29, 1897} & Port-au-Prince & $\begin{array}{l}\text { (Scherer and Baltenweck, 1914): 9 h. 33 m. 34 sec p.m., three strong tremors, } \\
\text { direction NE, 42 seconds duration, predominately vertical component. }\end{array}$ \\
\hline-72.3388 & 18.5432 & \begin{tabular}{l} 
- \\
\hline
\end{tabular}
\end{tabular}

\begin{tabular}{|c|c|c|c|c|}
\hline \multicolumn{5}{|c|}{ December 29, 1897} \\
\hline \multicolumn{5}{|c|}{$\begin{array}{l}\text { Time: 6:32:31 AM, Port-au-Prince local mean time (11:21:52 UTC) } \\
\text { Land Surface Observations: In the mountains north of Santiago the peak Diego Campo of 1,220 meters had enormous landslides. Also in the Yaque River valley } \\
\text { west of Santiago de los Caballeros, the earth opened up into gullies or collapsed, and some meadows turned into swamps. (Le Cosmos, 1898) } \\
\text { Submarine Landslide Observation: In Puerto Plata there were two submarine cables that left the mouth of the nearby Plata River and it was noted that the cable } \\
\text { going east to Martinique was cut once and the cable going west to Cap Haitien in three places during the earthquake (Le Cosmos, 1898). } \\
\text { Phenomenon Notes: This earthquake was recorded in Port-au-Prince at the Seminare-College St-Martial that had a Cecchi seismograph and a Bertelli } \\
\text { microseismometer operating at the time. The time and observations of the waveform are taken from Le Cosmos (1898) article. According to Agamennone (1898) } \\
\text { other instruments also recorded this earthquake in Toronto, Canada; Strasburg, Germany; Nicolas, Russia; and Shide, England, as well as in Italy, Rocca di Papa } \\
\text { (Frascati, Roma) and the island of Ischia (Napoli). Agamennone gave a preliminary epicenter location of -71.0 W, 19.5 N based on their interpretation of the reported } \\
\text { damages on the island. In Abe (1994), this earthquake was located only using the seismogram recorded in Europe to 11:18 UTC, } 19 \mathrm{NLat},-73 \mathrm{E} \text { Lon. Ms = } 6.8 \text {. } \\
\text { Number of Observations: } 16\end{array}$} \\
\hline Longitude & Latitude & City & Description & Intensity \\
\hline-70.8305 & 19.6717 & Altamira & $\begin{array}{l}\text { (New York Times, 1898a): The cathedral at Altamira on the crest of the } \\
\text { mountain range between Puerto Plata and Santiago was badly damaged. } \\
\text { (Agamennone, 1898): The walls and the tombs of the cemetery are no more } \\
\text { than a heap of ruins. On the railway, } 70 \text { km long, that runs through the } \\
\text { mountains between Puerto Plata and Santiago has a bridge of } 15 \text { meters in } \\
\text { the North direction where one of its pillars toppled and fell into the stream } \\
\text { Guanabano that it traverses; later a rock of } 4 \text { tons fell onto the track, then at } \\
\text { the large bend in Altamira, the rails were broken and thrown out of their } \\
\text { tracks where it runs in the N-S direction. However, neither the Cumbre } \\
\text { tunnel nor the great Guanabano viaduct has been damaged. } \\
\text { (Le Cosmos, 1898): At Altamira, the bounding walls and tombs of the } \\
\text { cemetery are a heap of rubble. } \\
\text { (Tomblin and Robson, } 1977 \text { quoting Jamaica Post Jan. 28, 1898): "Partly } \\
\text { disappeared" during the earthquake, but there was no loss of life. The } \\
\text { cemetery sank "as if nature has dropped an enormous pile-driver on the } \\
\text { spot" and tombs were ruined. } \\
\text { (Scherer, 1912a): But at Altamira, north of Santiago, all the monuments in } \\
\text { the cemetery and on the enclosing wall remain in a heap of ruins. }\end{array}$ & $\begin{array}{l}\text { CHF(8) } \\
\text { SISF(8) } \\
\text { T\&R1977(8) }\end{array}$ \\
\hline
\end{tabular}




\begin{tabular}{|c|c|c|c|c|}
\hline \multicolumn{5}{|c|}{ December 29, 1897} \\
\hline-70.6937 & 19.7971 & Puerto Plata & $\begin{array}{l}\text { (New York Times, 1898a): The Central Dominican Railroad was more or less } \\
\text { damaged all along the line. In the neighborhood of Puerto Plata many of the } \\
\text { embankments along the line were cracked and settled, and in one instance } \\
\text { one of the abutments was shaken entirely out of a fifty-foot span, and one } \\
\text { end of the bridge fell fifteen feet. Huge boulders were hurled down from the } \\
\text { mountains, breaking the rails and filling up many of the cuts. One large } \\
\text { storehouse at Puerto Plata was wrecked. } \\
\text { (de Utrera, 1995): The submarine cable tore in Puerto Plata. } \\
\text { (Tomblin and Robson, } 1977 \text { quoting Jamaica Post Jan. 28, 1898): There was little } \\
\text { damage, but the submarine cable, running from this city in two directions, } \\
\text { was interrupted once to the East between Rio Plata and Martinique, and } \\
\text { three times to the West between Rio Plata and Cape Haitien, which } \\
\text { occurred at the time of the same phenomenon. A violent earthquake, lasting } \\
\text { about } 25 \text { seconds. Sleepers ran outdoors. Followed by eight brief shocks } \\
\text { between 7:05 and 12:20. }\end{array}$ & $\begin{array}{l}\text { CHF(7) } \\
\text { S\&L1992(8) } \\
\text { T\&R1977(8) }\end{array}$ \\
\hline
\end{tabular}




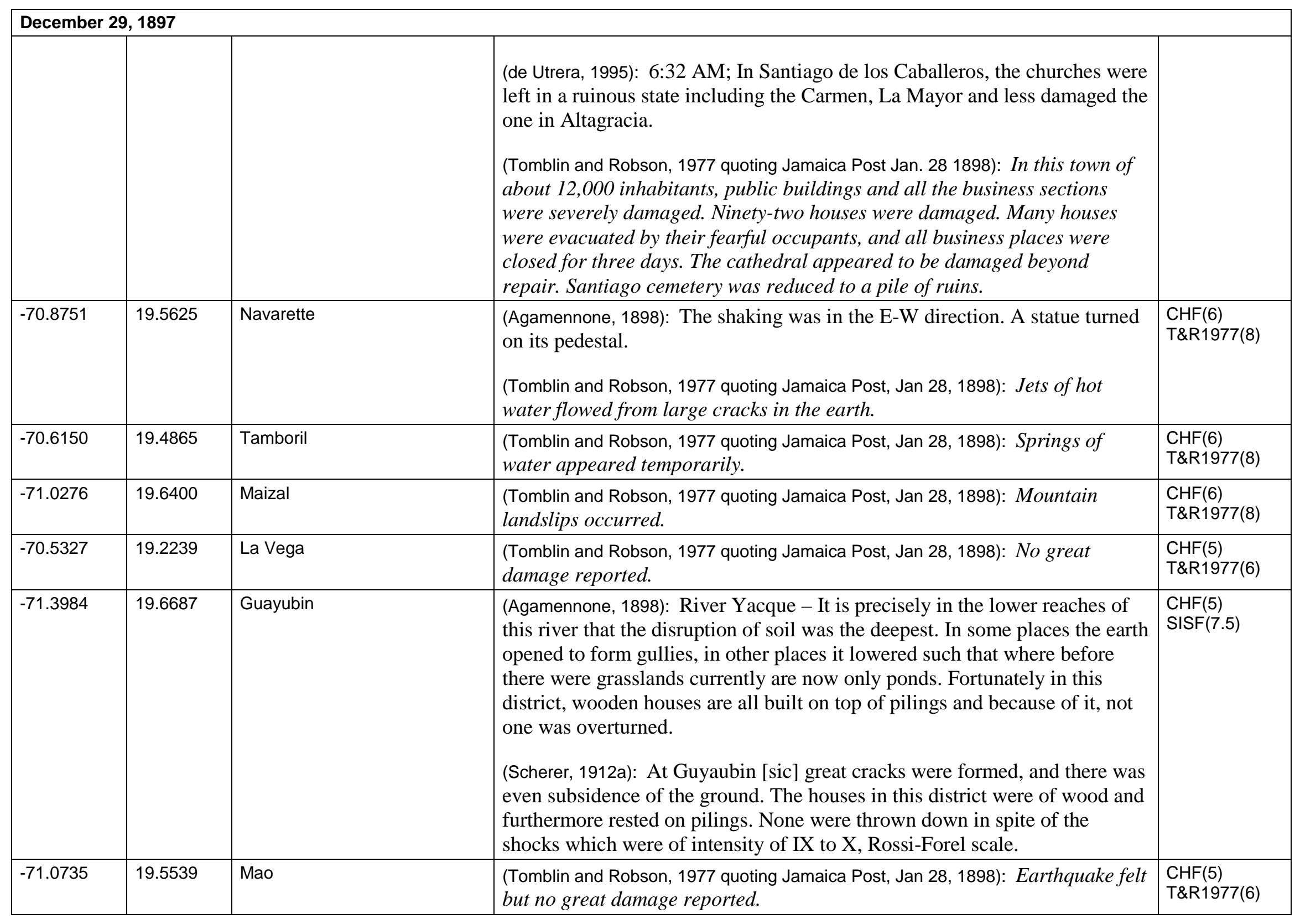




\begin{tabular}{|c|c|c|c|c|}
\hline \multicolumn{5}{|c|}{ December 29, 1897} \\
\hline-70.5468 & 19.2797 & Santa Cerro & $\begin{array}{l}\text { (New York Times, 1898a): The church at Santo Cerro was shaken to the } \\
\text { ground and more or less serious damage was done to buildings in a half } \\
\text { dozen villages and towns in the Yaqui Valley. }\end{array}$ & $\mathrm{CHF}(5)$ \\
\hline-72.1040 & 18.8336 & Mirebalais & $\begin{array}{l}\text { (Agamennone, 1898): The earthquake was felt there with the same } \\
\text { characteristics as in Port-au-Prince. } \\
\text { (Scherer, 1912a): The shock was also felt very forcibly at Mirebalais and at } \\
\text { Jacmel. }\end{array}$ & $\begin{array}{l}\mathrm{CHF}(4) \\
\operatorname{SISF}(6)\end{array}$ \\
\hline-69.8877 & 18.4722 & Santo Domingo & $\begin{array}{l}\text { (Agamennone, 1898): The earthquake was felt without much impression. } \\
\text { (Scherer, 1912a): It was feeble in Santo Domingo. }\end{array}$ & $\begin{array}{l}\text { CHF(3) } \\
\text { S\&L1992(5) }\end{array}$ \\
\hline-71.1462 & 21.4674 & $\begin{array}{l}\text { Cockburn Town, Great Turks } \\
\text { Island }\end{array}$ & $\begin{array}{l}\text { (Agamennone, 1898): At } 6 \mathrm{~h} 37 \mathrm{~m} \text { a.m. was felt a slight shock lasting a few } \\
\text { seconds. Several clocks stopped and no damage. }\end{array}$ & $\mathrm{CHF}(4)$ \\
\hline-76.7909 & 17.9840 & Kingston, Jamaica & (Agamennone, 1898): On this day, no shock was felt. Weather Office. & CHF(-) \\
\hline
\end{tabular}

\section{December 29, 1897, to January 25, 1898}

Time: Various times

Phenomenon Notes: Aftershocks of the December 29, 1897, earthquake.

Number of Observations: 3

\begin{tabular}{|l|l|l|l|l|}
\hline Longitude & Latitude & City & Description & Intensity \\
\hline-70.7075 & 19.4502 & Santiago de los Caballeros & (Agamennone, 1898): Thus at Santiago on the same December 29, another six & - \\
\hline
\end{tabular}




\begin{tabular}{|c|c|c|c|c|}
\hline Decembe & 1897 , to & uary 25,1898 & & \\
\hline-70.6937 & 19.7971 & Puerto Plata & $\begin{array}{l}\text { (Tomblin and Robson, } 1977 \text { quoting Jamaica Post Jan. 28, 1898): 1897, } \\
\text { December 29, 07:05 - shock lasting } 2 \text { seconds; 07:17 - shock lasting } 2 \\
\text { seconds; 07:45 - shock lasting } 4 \text { seconds; 08:35 - shock lasting } 1 \text { second; } \\
\text { 09:00 - shock lasting } 1 \text { second; 09:54 - shock lasting } 2 \text { seconds, 10:20 - } \\
\text { shock lasting } 1.5 \text { seconds, 12:20 - shock lasting } 2 \text { seconds; 13:25 - another } \\
\text { severe shock. }\end{array}$ & \\
\hline - & - & Hispaniola & $\begin{array}{l}\text { (Tomblin and Robson, 1977, quoting Jamaica Post, Jan 28, 1898): } 1897 \\
\text { December } 29 \text { to } 1898 \text { January 2, St. Domingo - Earthquakes continued at } \\
\text { intervals, the last severe shock occurring at 10:30 on January 2; } 1898 \\
\text { January } 2 \text { to January 27, several light shocks. } \\
\text { (Scherer, 1912a): The seismic disturbance lasted from December 29th to } \\
\text { January 25th and thirty-six shocks, more or less strong, were counted during } \\
\text { that time, about the region shaken since December 29th. }\end{array}$ & \\
\hline
\end{tabular}

\begin{tabular}{|c|c|c|c|c|}
\hline \multicolumn{5}{|c|}{\begin{tabular}{|l|} 
July 11,1898 \\
\end{tabular}} \\
\hline \multicolumn{5}{|c|}{$\begin{array}{l}\text { Time: 3:00 PM, Port-au-Prince mean local time (19:49:21 UTC) } \\
\text { Phenomenon Notes: Local mean time in Port-au-Prince is +04:49:21 of Greenwich time). } \\
\text { Number of Observations: } 7\end{array}$} \\
\hline Longitude & Latitude & City & Description & Intensity \\
\hline
\end{tabular}




\begin{tabular}{|c|c|c|c|c|}
\hline \multicolumn{5}{|c|}{ July 11, 1898} \\
\hline & & & $\begin{array}{l}\text { Haytien, Haiti at } 3 \text { o'clock yesterday afternoon. The disturbance lasted } 5 \\
\text { seconds, and was so severe as to have driven the inhabitants from their } \\
\text { homes in terror. No news of extent of damage or loss of life, if any was } \\
\text { received. }\end{array}$ & \\
\hline-72.3388 & 18.5432 & Port-au-Prince & $\begin{array}{l}\text { (Scherer and Baltenweck, 1914): 3h. PM fairly strong earthquake, intensity IV } \\
\text { [Rossi-Forel scale] direction NE, at } 5 \text { PM and 6:37 PM two other tremors, } \\
\text { direction E. }\end{array}$ & $\mathrm{CHF}(3)$ \\
\hline-72.2272 & 18.5758 & Croix-de-Bouquets & (Scherer and Baltenweck, 1914): 3H PM, felt. & $\mathrm{CHF}(3)$ \\
\hline-72.0630 & 18.5331 & Ganthier & (Scherer and Baltenweck, 1914): 3H PM, felt. & $\mathrm{CHF}(3)$ \\
\hline-72.6929 & 19.4458 & Gonaives & $\begin{array}{l}\text { (Scherer and Baltenweck, 1914): 3H PM, felt; a French liner harbored in } \\
\text { Gonaives felt an impact similar to a collision at 3:00 p.m. }\end{array}$ & $\mathrm{CHF}(3)$ \\
\hline-73.5466 & 18.2630 & Saint Luis du Sud & (Scherer and Baltenweck, 1914): 3H PM, felt. & $\mathrm{CHF}(3)$ \\
\hline-73.7500 & 18.1945 & Les Cayes & (Scherer and Baltenweck, 1914): 3H PM, felt. & $\mathrm{CHF}(3)$ \\
\hline
\end{tabular}




\section{Selected Earthquakes of the 20th Century:}

Intensity, Mercalli Magnitude Intensities (3-10); CHF, assigned by C. H. Flores (author); WHB, assigned by W. H. Bakun (author); SISF, assigned by SiSFrance/Antilles (2010); L\&S1995, assigned by Lynch and Shepherd (1995); C1972, assigned by Campbell (1972); LB1948, assigned by Lynch and Bodle (1948); -, no assignment.

\section{Time: 04:30:00 AM, Port-au-Prince local mean time (09:19:21 UTC)}

Phenomenon Notes: Port-au-Prince local mean time is equal to +04:49:21 Greenwich time.

Number of Observations: 4

\begin{tabular}{|l|l|l|l|l|}
\hline Longitude & Latitude & City & Description & Intensity \\
\hline-72.3388 & 18.5432 & Port-au-Prince & $\begin{array}{l}\text { (Scherer and Baltenweck, 1921): A very strong tremor at 4h. 30m. a.m., also } \\
\text { felt at Petionville, Furcy, and Ganthier. }\end{array}$ & - \\
\hline-72.2864 & 18.5107 & Petionville & $\begin{array}{l}\text { (Scherer and Baltenweck, 1921): A very strong tremor at 4h. 30m. a.m., also } \\
\text { felt at Petionville, Furcy, and Ganthier. }\end{array}$ & - \\
\hline-72.3062 & 18.4165 & Furcy & $\begin{array}{l}\text { (Scherer and Baltenweck, 1921): A very strong tremor at 4h. 30m. a.m., also } \\
\text { felt at Petionville, Furcy, and Ganthier. }\end{array}$ & - \\
\hline-72.0630 & 18.5331 & Ganthier & $\begin{array}{l}\text { (Scherer and Baltenweck, 1921): A very strong tremor at 4h. 30m. a.m., also } \\
\text { felt at Petionville, Furcy, and Ganthier. }\end{array}$ & - \\
\hline
\end{tabular}

\begin{tabular}{|l|l|l|l|l|}
\hline \multicolumn{4}{|l|}{ August 16, 1903 } & $\begin{array}{l}\text { Time: 08:50:28 AM, Port-au-Prince local mean time (13:39:49 UTC) } \\
\text { Phenomenon Notes: The Cecchi seismometer in Port-au-Prince recorded this earthquake. } \\
\text { Number of Observations: }\end{array}$ \\
\hline Longitude & Latitude & City & Description \\
\hline-72.3388 & 18.5432 & Port-au-Prince & $\begin{array}{l}\text { (Le Nouvelliste, 1903): Yesterday morning around 5 minutes before } 9 \text { a.m. a } \\
\text { quite strong shake from an earthquake was felt, that lasted several seconds. } \\
\text { The oscillations were from E-W. We do not believe there were damages to } \\
\text { the city. } \\
\text { (Scherer and Baltenweck, 1921): At 8h. 50m. 28s. Lasted } 64 \text { seconds. The } \\
\text { earthquake was recorded by the Cecchi seismograph [Continues into a } \\
\text { description of the physical recording of the seismogram.] This earthquake was not } \\
\text { very violent, no damage or cracks in the ground and no underground noise } \\
\text { was reported. }\end{array}$ \\
\hline-72.2864 & 18.5107 & Petionville & $\begin{array}{l}\text { (Scherer and Baltenweck, 1921): Petionville-Furcy, Direction NNW at first } \\
\text { and then N-E. }\end{array}$ \\
\hline
\end{tabular}




\begin{tabular}{|c|c|c|c|c|}
\hline \multicolumn{5}{|c|}{ August 16, 1903} \\
\hline-72.3062 & 18.4165 & Furcy & $\begin{array}{l}\text { (Scherer and Baltenweck, 1921): Petionville-Furcy, Direction NNW at first } \\
\text { and then N-E. }\end{array}$ & - \\
\hline-73.3447 & 18.5028 & Anse-a-Veau & $\begin{array}{l}\text { (Scherer and Baltenweck, 1921): Anse-a-Veau and Aquin, St. Marc, Port-de- } \\
\text { Paix, Direction E. }\end{array}$ & - \\
\hline-73.3971 & 18.2816 & Aquin & $\begin{array}{l}\text { (Scherer and Baltenweck, 1921): Anse-a-Veau and Aquin, St. Marc, Port-de- } \\
\text { Paix, Direction E. }\end{array}$ & - \\
\hline-72.6978 & 19.1081 & St. Marc & $\begin{array}{l}\text { (Scherer and Baltenweck, 1921): Anse-a-Veau and Aquin, St. Marc, Port-de- } \\
\text { Paix, Direction E. }\end{array}$ & - \\
\hline-72.8370 & 19.9408 & Port-de-Paix & $\begin{array}{l}\text { (Scherer and Baltenweck, 1921): Anse-a-Veau and Aquin, St. Marc, Port-de- } \\
\text { Paix, Direction E. }\end{array}$ & - \\
\hline-72.2006 & 19.7616 & Cap Haitien & (Scherer and Baltenweck, 1921): Cap-Haitien, lasted 4 minutes 50 seconds. & - \\
\hline-72.8296 & 20.9335 & Santiago, Cuba & (Scherer and Baltenweck, 1921): Santiago de Cuba at 8h. 35m. & - \\
\hline- & - & Dalmarie, Haiti [?] & $\begin{array}{l}\text { (Scherer and Baltenweck, 1921): Dalmarie, strong shaking, village church } \\
\text { damaged, lasted } 30 \text { seconds. }\end{array}$ & - \\
\hline
\end{tabular}

\section{April 4, 1905}

Time: 10:06:00 AM, Port-au-Prince local mean time (14:55:21 UTC)

Phenomenon Notes: None

Number of Observations: 4

\begin{tabular}{|c|c|c|c|c|}
\hline Longitude & Latitude & City & Description & Intensity \\
\hline-72.5345 & 18.2359 & Jacmel & (Scherer and Baltenweck, 1921): Strong tremor around 10 in the morning. & - \\
\hline-72.6334 & 18.5111 & Leogane & $\begin{array}{l}\text { (Scherer and Baltenweck, 1921): Tremor from an earthquake at } 10 \text { in the } \\
\text { morning. }\end{array}$ & \\
\hline-72.3388 & 18.5432 & Port-au-Prince & $\begin{array}{l}\text { (Scherer and Baltenweck, 1921): Very light tremor at } 10 \mathrm{~h} .6 \mathrm{~m} \text {. in the morning, } \\
\text { direction E. }\end{array}$ & - \\
\hline-72.2864 & 18.5107 & Petionville & $\begin{array}{l}\text { (Scherer and Baltenweck, 1921): Light tremor at 10h. 6m. in the morning, } \\
\text { direction E. }\end{array}$ & - \\
\hline
\end{tabular}

\section{October 12, 1905}

Time: About 05:00:00 PM, Jeremie local time (about 21:49:21 UTC)

Phenomenon Notes: None

Number of Observations: 2

\begin{tabular}{|l|l|l}
\hline Longitude & Latitude & City \\
\hline
\end{tabular} 


\begin{tabular}{|c|c|c|c|c|}
\hline \multicolumn{5}{|c|}{ October 12, 1905} \\
\hline-74.1145 & 18.6446 & Jeremie & (Scherer and Baltenweck, 1921): Earthquake around 5 o'clock in the evening. & - \\
\hline-73.7500 & 18.1945 & Les Cayes & (Scherer and Baltenweck, 1921): Earthquake around 5 o'clock in the evening. & - \\
\hline
\end{tabular}

\section{October 13, 1905}

Time: About 05:00:00 PM, Petit-Goave local time (about 21:49:21 UTC)

Phenomenon Notes: None

Number of Observations: 3

\begin{tabular}{|l|l|l|l|l|}
\hline Longitude & Latitude & City & Description & Intensity \\
\hline-72.8668 & 18.4315 & Petit-Goave & (Scherer and Baltenweck, 1921): Earthquake around 5 o'clock in the evening. & - \\
\hline-74.1145 & 18.6446 & Jeremie & (Scherer and Baltenweck, 1921): Earthquake around 5 o’clock in the evening. & - \\
\hline-73.7500 & 18.1945 & Les Cayes & (Scherer and Baltenweck, 1921): Earthquake around 5 o'clock in the evening. & - \\
\hline
\end{tabular}

\begin{tabular}{|c|c|c|c|c|}
\hline \multicolumn{5}{|c|}{ October 14, 1905} \\
\hline \multicolumn{5}{|c|}{$\begin{array}{l}\text { Time: 09:51:00 AM, Port-au-Prince local mean time (14:40:21 UTC) } \\
\text { Phenomenon Notes: A second earthquake was recorded at Port-au-Prince at 08:10 PM, local mean time (00:59:21 UTC, October 15, 1905) } \\
\text { Number of Observations: } 8\end{array}$} \\
\hline Longitude & Latitude & City & Description & Intensity \\
\hline-72.3388 & 18.5432 & Port-au-Prince & $\begin{array}{l}\text { (Le Nouvelliste,1905a): While we were at work, the tremor of an earthquake } \\
\text { was felt at } 9 \text { h. } 51 \mathrm{~m} \text {. with a low intensity. The oscillations lasted about } 4 \\
\text { seconds and had the direction North-East. } \\
\text { (Le Nouvelliste,1905b): Saturday and Sunday last on the } 14 \text { th and } 15 \text { of } \\
\text { October, there were four earthquakes felt - } 1 \text { st on the } 14 \text { th at } 9 \text { hours } 51 \\
\text { minutes in the morning, direction ENE; duration } 4 \text { seconds, intensity II. - } \\
\text { 2nd on the } 14 \text { th at } 8 \text { hours } 10 \text { minutes in the evening; direction ENE } \\
\text { duration } 2 \text { seconds, intensity I. Intensity I - felt by seismometers only; } \\
\text { Intensity II - felt by a few persons at rest. } \\
\text { (Scherer and Baltenweck, 1921): Earthquake at } 9 \mathrm{~h} \text {. } 51 \mathrm{~m} \text { in the morning, } \\
\text { earthquake at } 8 \mathrm{~h} .10 \mathrm{~m} \text {. in the evening. }\end{array}$ & - \\
\hline-73.3745 & 19.8052 & Mole-St. Nicolas & (Scherer and Baltenweck, 1921): Earthquake at 9h. 51m in the morning. & - \\
\hline-72.1040 & 18.8336 & Mirebalais & (Scherer and Baltenweck, 1921): Earthquake at 9h. 51m in the morning. & - \\
\hline-72.5345 & 18.2359 & Jacmel & (Scherer and Baltenweck, 1921): Earthquake at 9h. 51m in the morning. & - \\
\hline-72.8668 & 18.4315 & Petit-Goave & (Scherer and Baltenweck, 1921): Earthquake at 9h. 51m in the morning. & - \\
\hline
\end{tabular}




\begin{tabular}{|l|l|l|l|l|}
\hline \multicolumn{4}{|l|}{ October 14, 1905} & (Scherer and Baltenweck, 1921): Earthquake at 9h. 51m in the morning. \\
\hline-73.0861 & 18.4423 & Miragoane & (Scherer and Baltenweck, 1921): Earthquake at 9h. 51m in the morning. & - \\
\hline-74.1145 & 18.6446 & Jeremie & (Scherer and Baltenweck, 1921): Earthquake at 9h. 51m in the morning. & - \\
\hline-73.7500 & 18.1945 & Les Cayes &
\end{tabular}

\begin{tabular}{|c|c|c|c|c|}
\hline \multicolumn{5}{|c|}{ October 15, 1905} \\
\hline \multicolumn{5}{|c|}{$\begin{array}{l}\text { Time: } 04: 52: 41 \text { PM, Port-au-Prince local mean time (21:42:02 UTC). } \\
\text { Phenomenon Notes: A second earthquake was recorded in Port-au-Prince at 06:19 PM, local mean time (23:08:21 UTC). Father J. Scherer reported observations } \\
\text { in the Nouvelliste newspaper for October 17, } 1905 . \\
\text { Number of Observations: } 9\end{array}$} \\
\hline-72.3388 & 18.5432 & Port-au-Prince & $\begin{array}{l}\text { (Le Nouvelliste,1905b): Saturday and Sunday last on the 14th and } 15 \text { of } \\
\text { October, there were four earthquakes felt - 3rd on the 15th at } 4 \text { hours } 54 \\
\text { minutes } 41 \text { seconds in the evening, direction NE; intensity III, duration } 42 \\
\text { seconds total. There were five successive shakes separated by short calm } \\
\text { periods. First tremor lasted } 6 \text { seconds, calm for } 1 \text { second. Second tremor } \\
\text { duration } 9 \text { seconds, calm for } 3 \text { seconds with horizontal oscillations, while } \\
\text { the vertical component was very significant. Third tremor duration } 8 \\
\text { seconds, calm for } 6 \text { seconds. Fifth tremor duration } 4 \text { seconds. - } 4 \text { th on the } \\
\text { 15th at } 6 \text { hours } 19 \text { minutes, direction NE duration } 3 \text { seconds, intensity I. } \\
\text { Intensity I - felt by seismometers only; intensity III felt by everyone at rest; } \\
\text { they can perceive the direction of motion and duration. } \\
\text { (Scherer and Baltenweck, 1921): First earthquake at } 4 \mathrm{~h} \text {. } 54 \mathrm{~m} \text {. } 41 \mathrm{~s} \text { in the } \\
\text { evening, second earthquake at } 6 \mathrm{~h} \text {. } 19 \mathrm{~m} \text {. in the evening. }\end{array}$ & - \\
\hline-74.1145 & 18.6446 & Jeremie & (Scherer and Baltenweck, 1921): Strong tremor from an earthquake. & - \\
\hline-72.1260 & 19.6688 & Limonade & (Scherer and Baltenweck, 1921): Two tremors from earthquakes. & - \\
\hline-73.0861 & 18.4423 & Miragoane & (Scherer and Baltenweck, 1921): Two tremors from earthquakes. & - \\
\hline-73.7500 & 18.1945 & Les Cayes & (Scherer and Baltenweck, 1921): Two tremors from earthquakes. & - \\
\hline-73.3745 & 19.8052 & Mole-St. Nicolas & (Scherer and Baltenweck, 1921): Weak tremor of an earthquake. & - \\
\hline-72.6836 & 19.6699 & Gros-Morne & (Scherer and Baltenweck, 1921): Weak tremor of an earthquake. & - \\
\hline-72.5345 & 18.2359 & Jacmel & (Scherer and Baltenweck, 1921): Weak tremor of an earthquake. & - \\
\hline
\end{tabular}

February 8, 1906 


\begin{tabular}{|c|c|c|c|c|}
\hline \multicolumn{5}{|c|}{ February 8, 1906} \\
\hline \multicolumn{5}{|c|}{$\begin{array}{l}\text { Time: February 9, at 00:04:00 AM, Port-au-Prince local mean time (04:53:21 UTC) } \\
\text { Phenomenon Notes: Second tremor felt at 00:21:00 AM (05:10:21 UTC). } \\
\text { Number of Observations: } 2\end{array}$} \\
\hline Longitude & Latitude & City & Description & Intensity \\
\hline-72.8668 & 18.4315 & Petit-Goave & $\begin{array}{l}\text { (Destouches, 1906a): Earthquakes on the 9th [February] at 0h. 04m. and 0h } \\
\text { 21m., felt at Petit-Goave and Leogane. } \\
\text { (Scherer and Baltenweck, 1921): Light tremor from an earthquake. }\end{array}$ & - \\
\hline-72.6334 & 18.5111 & Leogane & $\begin{array}{l}\text { (Destouches, 1906a): Earthquakes on the } 9 \text { th [February] at } 0 \mathrm{~h} .04 \mathrm{~m} \text {. and } 0 \mathrm{~h} \\
21 \mathrm{~m} . \text {, felt at Petit-Goave and Leogane. }\end{array}$ & - \\
\hline-73.0861 & 18.4423 & Miragoane & (Scherer and Baltenweck, 1921): Light tremor from an earthquake. & - \\
\hline
\end{tabular}

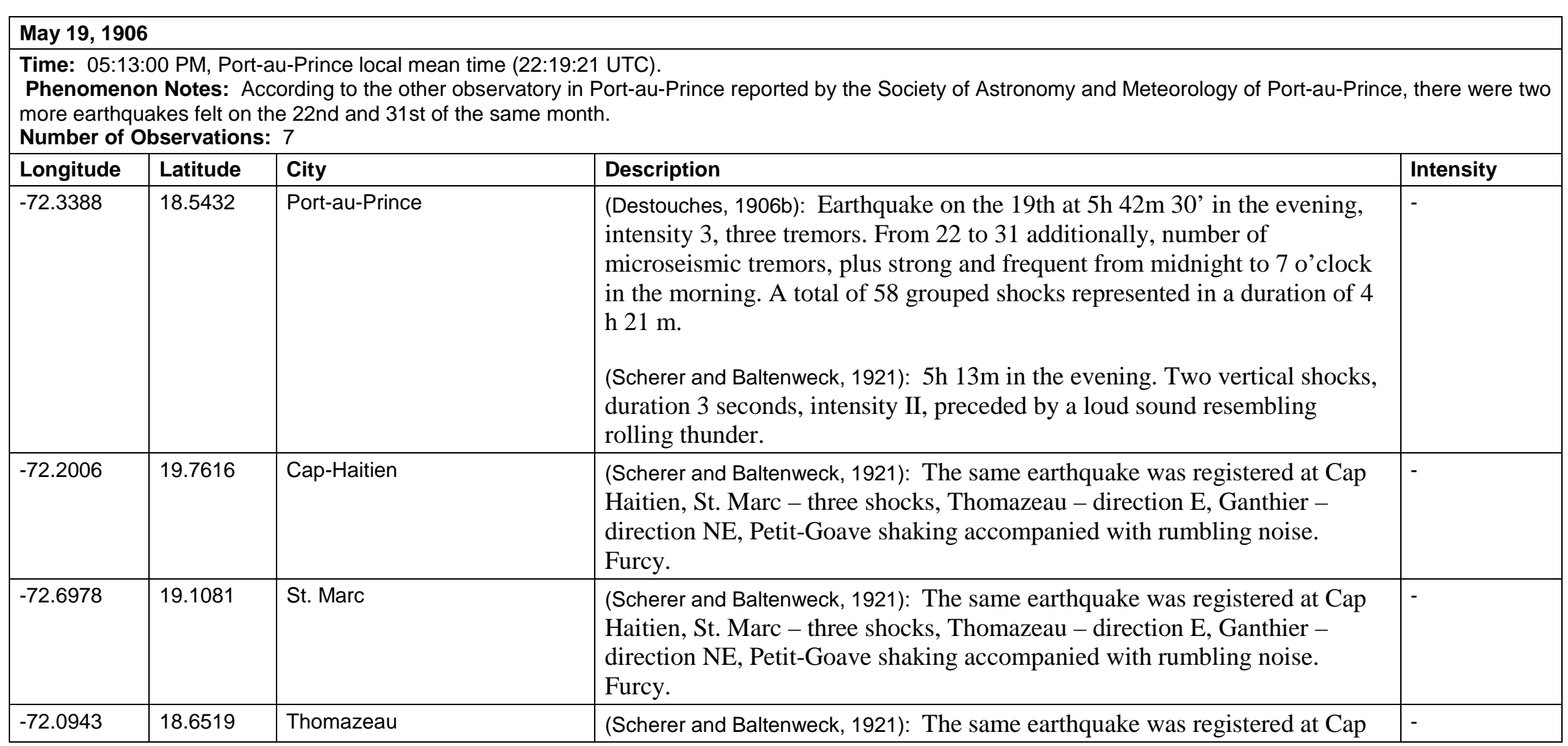




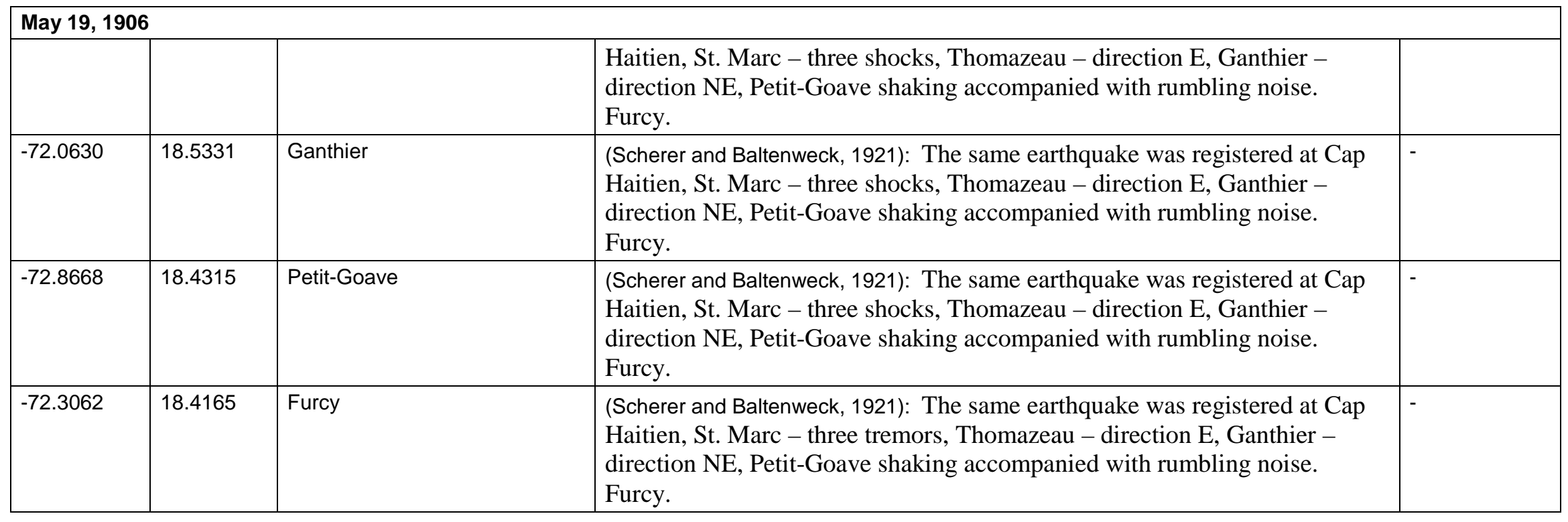

\section{June 15, 1906}

Time: 02:33:00 PM, Port-au-Prince local mean time (19:22:21 UTC)

Phenomenon Notes: None

Number of Observations: 1

\begin{tabular}{|l|l|l|l|l|}
\hline Longitude & Latitude & City & Description & Intensity \\
\hline-72.3388 & 18.5432 & Port-au-Prince & $\begin{array}{l}\text { (Scherer and Baltenweck, 1921): Light shock at 2 h 33 m in the afternoon. } \\
\text { Intensity I, direction ENE, 4 seconds duration. }\end{array}$ \\
\hline
\end{tabular}

\section{June 22, 1906}

Time: 02:30:00 AM and 03:00 AM, Jeremie local time (about 07:19:21 UTC)

Phenomenon Notes: A second tremor was felt at 03:00:00 AM Jeremie local time (about 07:49:21 UTC)

Number of Observations: 1

\begin{tabular}{|l|l|l|l|l|}
\hline Longitude & Latitude & City & Description & Intensity \\
\hline-74.1145 & 18.6446 & Jeremie & $\begin{array}{l}\text { (Scherer and Baltenweck, 1921): Two earthquakes at 2 h 30 m and 3 h in the } \\
\text { morning. }\end{array}$ & - \\
\hline
\end{tabular}

\section{July 20, 1906}

Time: 04:00:00 AM, Les Cayes local time (about 08:49:21 UTC)

Phenomenon Notes: None 


\begin{tabular}{|c|c|c|c|c|}
\hline \multicolumn{5}{|c|}{ July 20, 1906} \\
\hline \multicolumn{5}{|c|}{ Number of Observations: 1} \\
\hline Longitude & Latitude & City & Description & Intensity \\
\hline-73.7500 & 18.1945 & Les Cayes & (Scherer and Baltenweck, 1921): Light tremor at $4 \mathrm{~h}$ in the morning. & - \\
\hline
\end{tabular}

\begin{tabular}{|c|c|c|c|c|}
\hline \multicolumn{5}{|c|}{ August 3, 1906} \\
\hline \multicolumn{5}{|c|}{$\begin{array}{l}\text { Time: 05:00:00 AM, Jacmel local time (about 09:49:21 UTC) } \\
\text { Phenomenon Notes: None } \\
\text { Number of Observations: } 1\end{array}$} \\
\hline Longitude & Latitude & City & Description & Intensity \\
\hline-72.5345 & 18.2359 & Jacmel & $\begin{array}{l}\text { (Scherer and Baltenweck, 1921): Light tremor at } 5 \mathrm{~h} \text { in the morning, direction } \\
\text { E. }\end{array}$ & - \\
\hline
\end{tabular}

\section{October 16, 1906}

Time: 09:00:00 PM, Bainet local time (about 01:49:21 UTC, October 17, 1906)

Phenomenon Notes: None

Number of Observations: 1

\begin{tabular}{|l|l|l|l|l|}
\hline Longitude & Latitude & City & Description & Intensity \\
\hline-72.7558 & 18.1819 & Bainet & (Scherer and Baltenweck, 1921): Light tremor at 9 h at night. \\
\hline
\end{tabular}

\section{January 24, 1907}

Time: 11:00:00 PM, Jacmel local time (about 03:49:21 UTC, January 25, 1907)

Phenomenon Notes: None

Number of Observations: 1

\begin{tabular}{|l|l|l|l|l|}
\hline Longitude & Latitude & City & Description & Intensity \\
\hline-72.5345 & 18.2359 & Jacmel & (Scherer and Baltenweck, 1921): Light tremor at 11 h at night. & - \\
\hline
\end{tabular}

\section{January 25, 1907}

Time: 03:14:50 AM, Port-au-Prince local mean time (08:04:11 UTC)

Phenomenon Notes: None

Number of Observations: 6

\begin{tabular}{|l|l|l|l|l|}
\hline Longitude & Latitude & City & Description & Intensity \\
\hline-72.5345 & 18.2359 & Jacmel & (Scherer and Baltenweck, 1921): Very strong tremor about 3 h in the morning. & - \\
\hline-72.7558 & 18.1819 & Bainet & $\begin{array}{l}\text { (Scherer and Baltenweck, 1921): Very strong tremor about 3 h in the morning, } \\
\text { duration 5 seconds. }\end{array}$ & - \\
\hline
\end{tabular}




\begin{tabular}{|l|l|l|l|}
\hline \multicolumn{2}{|l|}{ January 25, 1907} & Miragoane & $\begin{array}{l}\text { (Scherer and Baltenweck, 1921): Strong tremor about 3 h 25 m in the morning, } \\
\text { duration 5 seconds. }\end{array}$ \\
\hline-73.0861 & 18.4423 & $\begin{array}{l}\text { (Scherer and Baltenweck, 1921): Light tremor about 3 h in the morning, } \\
\text { duration 6 seconds. }\end{array}$ \\
\hline-72.6929 & 19.4458 & Gonaives & $\begin{array}{l}\text { (Scherer and Baltenweck, 1921): Light tremor at 3 h 40 m in the morning, } \\
\text { direction W, duration 3 seconds. }\end{array}$ \\
\hline-72.3388 & 18.5432 & Port-au-Prince & $\begin{array}{l}\text { (Scherer and Baltenweck, 1921): Tremor at 3 h 14 m 50 s in the morning. } \\
\text { Direction W with a vertical component. Intensity above I. }\end{array}$ \\
\hline
\end{tabular}

\section{March 11, 1907}

Time: 03:25:00 AM, Jacmel local time (about 08:14:21 UTC)

Phenomenon Notes: None

Number of Observations: 1

\begin{tabular}{|l|l|l|l|l|}
\hline Longitude & Latitude & City & Description & Intensity \\
\hline-72.5345 & 18.2359 & Jacmel & (Scherer and Baltenweck, 1921): An earthquake at $3 \mathrm{~h} \mathrm{25} \mathrm{m}$ in the morning. & - \\
\hline
\end{tabular}

\section{April 19, 1907}

Time: 06:00:00 AM, Les Cayes local time (about 10:49:21 UTC)

Phenomenon Notes: None

Number of Observations: 1

\begin{tabular}{|l|l|l|l|l|}
\hline Longitude & Latitude & City & Description & Intensity \\
\hline-73.7500 & 18.1945 & Les Cayes & (Scherer and Baltenweck, 1921): Light tremor at 6 h. a.m. \\
\hline
\end{tabular}

\section{April 30, 1907}

Time: 05:00:00 PM, Les Cayes local time (about 21:49:21 UTC)

Phenomenon Notes: None

Number of Observations: 1

\begin{tabular}{|l|l|l|l|l|}
\hline Longitude & Latitude & City & Description & Intensity \\
\hline-73.7500 & 18.1945 & Les Cayes & (Scherer and Baltenweck, 1921): Light tremor at 5 h. p.m. & - \\
\hline
\end{tabular}

\section{May 3, 1907}

Time: 04:40:00 AM, Port-au-Prince local mean time (09:29:21 UTC)

Phenomenon Notes: None

Number of Observations: 11

\begin{tabular}{l|l|l} 
Longitude & Latitude & City \\
\hline
\end{tabular} 


\begin{tabular}{|c|c|c|c|c|}
\hline \multicolumn{5}{|c|}{ May 3, 1907} \\
\hline-72.2006 & 19.7616 & Cap Haitien & $\begin{array}{l}\text { (Scherer and Baltenweck, 1921): One strong tremor at } 4 \text { h } 35 \text { a.m. lasting } 9 \\
\text { seconds and preceded by a rolling sound. Direction WNW to ESE, the same } \\
\text { at Limonade, Trou, and Ouanaminthe. }\end{array}$ & - \\
\hline-72.1260 & 19.6688 & Limonade & $\begin{array}{l}\text { (Scherer and Baltenweck, 1921): One strong tremor at } 4 \text { h } 35 \text { a.m. lasting } 9 \\
\text { seconds and preceded by a rolling sound. Direction WNW to ESE, the same } \\
\text { at Limonade, Trou, and Ouanaminthe. }\end{array}$ & - \\
\hline-72.0223 & 19.6186 & Trou-du-Nord & $\begin{array}{l}\text { (Scherer and Baltenweck, 1921): One strong tremor at } 4 \text { h } 35 \text { a.m. lasting } 9 \\
\text { seconds and preceded by a rolling sound. Direction WNW to ESE, the same } \\
\text { at Limonade, Trou, and Ouanaminthe. }\end{array}$ & - \\
\hline-71.7223 & 19.5501 & Ouanaminthe & $\begin{array}{l}\text { (Scherer and Baltenweck, 1921): One strong tremor at } 4 \text { h } 35 \text { a.m. lasting } 9 \\
\text { seconds and preceded by a rolling sound. Direction WNW to ESE, the same } \\
\text { at Limonade, Trou, and Ouanaminthe. }\end{array}$ & - \\
\hline-72.837 & 19.9408 & Grande Riviere & (Scherer and Baltenweck, 1921): Strong tremor at $5 \mathrm{~h}$ a.m. the same at Bahon. & - \\
\hline-72.4308 & 19.8144 & Bayeux & (Scherer and Baltenweck, 1921): Very strong tremor at $4 \mathrm{~h}$ in the morning. & - \\
\hline-72.837 & 19.9408 & Port-au-Paix & $\begin{array}{l}\text { (Scherer and Baltenweck, 1921): Strong tremor at } 5 \text { h. in the morning, } \\
\text { direction S to N. }\end{array}$ & - \\
\hline-72.6929 & 19.4458 & Gonaives & (Scherer and Baltenweck, 1921): Strong tremor at 5 h. a.m., lasting 5 seconds. & - \\
\hline-72.6978 & 19.1081 & St. Marc & (Scherer and Baltenweck, 1921): Three successive tremors at 4 h 30 a.m. & - \\
\hline-72.0943 & 18.6519 & Thomazeau & $\begin{array}{l}\text { (Scherer and Baltenweck, 1921): Two tremors with three seconds intervals at } 4 \\
\text { h } 40 \text { a.m. }\end{array}$ & - \\
\hline-72.3388 & 18.5432 & Port-au-Prince & $\begin{array}{l}\text { (Scherer and Baltenweck, 1921): Strong microseismic agitation at } 4 \text { h.; } 4 \mathrm{~h} \\
40 \mathrm{~m} \text { and } 6 \mathrm{~h} 10 \mathrm{~m} \mathrm{a.} \mathrm{m} .\end{array}$ & - \\
\hline
\end{tabular}

\section{May 9, 1907}

Time: 02:15:00 PM, Jacmel local time (about 19:04:21 UTC)

Phenomenon Notes: None

Number of Observations: 1

\begin{tabular}{|l|l|l|l|l|}
\hline Longitude & Latitude & City & Description & Intensity \\
\hline-72.5345 & 18.2359 & Jacmel & (Scherer and Baltenweck, 1921): Light tremor at 2h 15m p.m. \\
\hline
\end{tabular}

\section{August 28, 1907}

Time: 05:10:00 AM, Baraderes local time (about 09:59:21 UTC)

Phenomenon Notes: None

Number of Observations: 1 


\begin{tabular}{|l|l|l|l|l|}
\hline \multicolumn{4}{|l|}{ August 28, 1907} & Description \\
\hline Longitude & Latitude & City & (Scherer and Baltenweck, 1921): Light tremor at 5h 10m a.m. \\
\hline-73.6387 & 18.4829 & Baraderes & - \\
\hline
\end{tabular}

\section{April 8, 1908}

Time: 09:15:00 PM, Miragoane local time (about 02:04:21 UTC, April 9, 1908)

Phenomenon Notes: None

Number of Observations: 1

\begin{tabular}{|l|l|l|l|l|}
\hline Longitude & Latitude & City & Description & Intensity \\
\hline 73.0861 & 18.4423 & Miragoane & (Scherer and Baltenweck, 1921): Weak tremor at 9h 15m p.m. & - \\
\hline
\end{tabular}

\section{May 12, 1908}

Time: 02:00:00 PM, Ganthier local time (about 18:49:21 UTC)

Phenomenon Notes: None

Number of Observations: 1

\begin{tabular}{|l|l|l|l|l|}
\hline Longitude & Latitude & City & Description & Intensity \\
\hline-72.0630 & 18.5331 & Ganthier & $\begin{array}{l}\text { (Scherer and Baltenweck, 1921): Fonds-Verrette (Ganthier): Tremor, quite } \\
\text { sensitive at 2 h p.m. }\end{array}$ \\
\hline
\end{tabular}

\section{May 25, 1908}

Time: 04:20:00 PM, Jacmel local time (about 21:09:21 UTC)

Phenomenon Notes: None

Number of Observations: 1

\begin{tabular}{|l|l|l|l|l|}
\hline Longitude & Latitude & City & Description & Intensity \\
\hline-72.5345 & 18.2359 & Jacmel & (Scherer and Baltenweck, 1921): Light tremor at 4 h 20 m p.m., direction NS. & -
\end{tabular}

\section{August 17, 1908}

Time: 06:00:00 AM, Les Cayes local time (about 10:49:21 UTC)

Phenomenon Notes: None

Number of Observations: 1

\begin{tabular}{|l|l|l|l|l|}
\hline Longitude & Latitude & City & Description & Intensity \\
\hline-73.7500 & 18.1945 & Les Cayes & (Scherer and Baltenweck, 1921): Tremor at 6 h a.m. \\
\hline
\end{tabular}

\section{September 28, 1908}

Time: 04:00:00 AM, Les Cayes local time (about 08:49:21 UTC)

Phenomenon Notes: Other earthquakes felt on this same day but at very different times. In Saltrou at 00:25:00 AM, arrival time recorded at Port-au-Prince 
(05:14:21 UTC). In Pestel at 04:30:00 AM (about 09:19:21 UTC) and in Mirebalais at 04:45:00 AM (about 09:34:21 UTC). Times taken from Scherer and Baltenweck (1921).

Number of Observations: 3

\begin{tabular}{|l|l|l|l|l|}
\hline Longitude & Latitude & City & Description & Intensity \\
\hline-73.7500 & 18.1945 & Les Cayes & (Scherer and Baltenweck, 1921): A tremor at 4 h a.m. & -
\end{tabular}

\section{October 25, 1908}

Time: 11:00:00 AM, Miragoane local time (about 15:49:21 UTC)

Phenomenon Notes: None

Number of Observations: 1

\begin{tabular}{|l|l|l|l|l|}
\hline Longitude & Latitude & City & Description & Intensity \\
\hline-73.0861 & 18.4423 & Miragoane & (Scherer and Baltenweck, 1921): Very strong tremor at 11 h. a.m. \\
\hline
\end{tabular}

\section{October 28, 1908}

Time: 05:00:00 AM, Miragoane local time (about 09:49:21 UTC)

Phenomenon Notes: None

Number of Observations: 1

\begin{tabular}{|l|l|l|l|l|}
\hline Longitude & Latitude & City & Description & Intensity \\
\hline-73.0861 & 18.4423 & Miragoane & (Scherer and Baltenweck, 1921): Light tremor at 5 h. a.m. & -
\end{tabular}

\section{March 31, 1909}

Time: 06:10:00 AM Miragoane local time, recored in Port-au-Prince at 06:20:00 AM (11:09:21 UTC)

Phenomenon Notes: Three more earthquakes were felt at Miragoane on the same day at 08:40:00 PM, 09:40:00 PM and 11:00:00 PM local time. Earthquakes were also felt in Mole-St.Nicolas and Port-de-Paix but may be too far north to be associated with the ones centering at Miragoane. The earthquakes were recorded at Port-au-Prince with times of 06:20:00 AM (11:09:21 UTC), 01:20:00 PM to 02:00:00 PM (06:09:21 UTC to 06:49:21 UTC), and 08:50:00 PM (01:39:21 UTC, April 1, 1909). Descriptions first published by the Port-au-Prince observatory for January-June, 1909 (Scherer, 1909).

Number of Observations: 8

\begin{tabular}{|c|c|c|c|c|}
\hline Longitude & Latitude & City & Description & Intensity \\
\hline-73.0861 & 18.4423 & Miragoane & $\begin{array}{l}\text { (Scherer and Baltenweck, 1921): 6h } 10 \text { a.m. Strong tremor; at } 8 \mathrm{~h} 40 \text { p.m. two } \\
\text { tremors at one minute intervals; } 4 \text { tremors between } 9 \mathrm{~h} 40 \text { and } 11 \mathrm{~h} \text { p.m. }\end{array}$ & - \\
\hline-73.3447 & 18.5028 & Anse-a-Veau & (Scherer and Baltenweck, 1921): 6 h 10 a.m. Strong tremor. & - \\
\hline-72.8668 & 18.4315 & Petit-Goave & $\begin{array}{l}\text { (Scherer and Baltenweck, 1921): } 6 \text { h } 30 \text { m a.m. Tremor recognized by } \\
\text { everybody; Tremor recognized by everybody at } 8 \text { h } 45 \text { p.m. }\end{array}$ & - \\
\hline-72.3388 & 18.5432 & Port-au-Prince & $\begin{array}{l}\text { (Scherer and Baltenweck, 1921): Microseismic movement at } 6 \text { h } 20 \text { m a.m.; } \\
\text { One quite sensitively felt by many persons at } 8 \text { h } 52 \text { p.m., direction NE, }\end{array}$ & - \\
\hline
\end{tabular}




\begin{tabular}{|l|l|l|l|l|}
\hline \multicolumn{2}{|l|}{ March 31, 1909} & & intensity I. \\
\hline & & Arcahaie & (Scherer and Baltenweck, 1921): Weak tremor at 8 h 45 p.m. \\
\hline-72.5126 & 18.7701 & Bainet & (Scherer and Baltenweck, 1921): Light tremor at 9 h 40 p.m. lasting 3 seconds. & - \\
\hline-73.7745 & 19.8052 & Mole-St. Nicolas & second. & - \\
\hline-72.8370 & 19.9408 & Port-de-Paix & (Scherer and Baltenweck, 1921): Tremor at 8 h 40 p.m. Direction NE. \\
\hline
\end{tabular}

\section{April 1, 1909}

Time: Between 02:00 and 03:00 AM, Miragoane local time (between about 06:49:21 UTC and 07:49:21 UTC)

Phenomenon Notes: Probable aftershocks of March 31, 1909. Original descriptions were published by the Port-au-Prince observatory for January-June 1909 (Scherer, 1909).

Number of Observations: 2

\begin{tabular}{|l|l|l|l|l|}
\hline Longitude & Latitude & City & Description & Intensity \\
\hline-73.0861 & 18.4423 & Miragoane & (Scherer and Baltenweck, 1921): Between 2 h and 3 h a.m. two weak tremors. & - \\
\hline-72.7558 & 18.1819 & Bainet & (Scherer and Baltenweck, 1921): Two weak tremors at 4 h a.m. & - \\
\hline
\end{tabular}

\section{April 2, 1909}

Time: 02:20 AM, Miragoane local time (about 07:09:21 UTC)

Phenomenon Notes: Aftershocks of April 1 with a second one at 02:30:00 PM Miragoane local time. Original description published by the Port-au-Prince observatory for January-June 1909 (Scherer, 1909).

Number of Observations: 1

\begin{tabular}{|l|l|l|l|l|}
\hline Longitude & Latitude & City & Description & Intensity \\
\hline-73.0861 & 18.4423 & Miragoane & $\begin{array}{l}\text { (Scherer and Baltenweck, 1921): 2 h 20 a.m. two strong tremors; } 2 \text { h 30 p.m. } \\
\text { two strong tremors. }\end{array}$ \\
\hline
\end{tabular}

\section{April 6, 1909}

Time: 02:00:00 AM, Miragoane local time (about 06:49:21 UTC)

Phenomenon Notes: Possible aftershock; the original description published by the Port-au-Prince observatory for January-June 1909 (Scherer, 1909). Number of Observations: 1

\begin{tabular}{|l|l|l|l|l|}
\hline Longitude & Latitude & City & Description & Intensity \\
\hline-73.0861 & 18.4423 & Miragoane & (Scherer and Baltenweck, 1921): 2 h. a.m. one weak tremor. \\
\hline
\end{tabular}

\section{April 10, 1909}




\begin{tabular}{|c|c|c|c|c|}
\hline \multicolumn{5}{|c|}{ April 10, 1909} \\
\hline \multicolumn{5}{|c|}{$\begin{array}{l}\text { Time: 04:30:00 PM, Miragoane local time (about 21:19:21 UTC) } \\
\text { Phenomenon Notes: Possible aftershock; the original description published by the Port-au-Prince observatory for January-June 1909 (Scherer, 1909). } \\
\text { Number of Observations: } 1\end{array}$} \\
\hline Longitude & Latitude & City & Description & Intensity \\
\hline-73.0861 & 18.4423 & Miragoane & $\begin{array}{l}\text { (Scherer and Baltenweck, 1921): } 4 \text { h } 30 \text { p.m. weak tremor. "During this time } \\
\text { of the earthquakes there was general panic and people have slept outside in } \\
\text { the porches. There was no material damage, except for a few walls } \\
\text { cracked." Mr. A. Tovar. }\end{array}$ & - \\
\hline
\end{tabular}

\section{August 2, 1909}

Time: Unknown

Phenomenon Notes: Description originally published by the Port-au-Prince observatory for July-December 1909 (Scherer, $1910 \mathrm{a})$

Number of Observations: 1

\begin{tabular}{|l|l|l|l|l|}
\hline Longitude & Latitude & City & Description & Intensity \\
\hline-74.1145 & 18.6446 & Jeremie & $\begin{array}{l}\text { (Scherer and Baltenweck, 1921): Earthquake within the surrounding area } \\
\text { without indication of the time. }\end{array}$ \\
\hline
\end{tabular}

\section{August 17, 1909}

Time: 12:00:00 PM, Tiburon local time (about 16:49:21 UTC)

Phenomenon Notes: Second earthquake felt at 01:00:00 PM, Tiburon local time (about 17:49:21 UTC). Description originally published by the Port-au-Prince observatory for July-December 1909 (Scherer, 1910a)

Number of Observations: 1

\begin{tabular}{|l|l|l|l|l|}
\hline Longitude & Latitude & City & Description \\
\hline-74.3959 & 18.3242 & Tiburon & $\begin{array}{l}\text { (Scherer and Baltenweck, 1921): Two tremors, one at midday and the other at } \\
1 \text { h p.m. direction N. }\end{array}$ \\
\hline
\end{tabular}

\section{October 31, 1909}

Time: Unknown

Phenomenon Notes: Description originally published by the Port-au-Prince observatory for July-December 1909 (Scherer, $1910 a)$

Number of Observations: 1

\begin{tabular}{|l|l|l|l|l|}
\hline Longitude & Latitude & City & Description & Intensity \\
\hline-74.4222 & 18.5605 & Dame-Marie & $\begin{array}{l}\text { (Scherer and Baltenweck, 1921): One strong tremor without indication of the } \\
\text { time. }\end{array}$ & - \\
\hline
\end{tabular}

\section{November 11, 1909}




\section{November 11, 1909}

Time: At night

Phenomenon Notes: Description originally published by the Port-au-Prince observatory for July-December 1909 (Scherer, $1910 \mathrm{a}$ )

Number of Observations: 2

\begin{tabular}{|l|l|l|l|l|}
\hline Longitude & Latitude & City & Description & Intensity \\
\hline-72.5345 & 18.2359 & Jacmel & (Scherer and Baltenweck, 1921): One light tremor during the night. & - \\
\hline-74.1145 & 18.6446 & Jeremie & (Scherer and Baltenweck, 1921): One light tremor during the night. & - \\
\hline
\end{tabular}

\section{February 3, 1910}

Time: 08:32:00 PM, Port-au-Prince local mean time (01:21:21 UTC, February 4, 1910)

Phenomenon Notes: Description originally published by the Port-au-Prince observatory for July-December 1909 (Scherer, $1910 a)$.

Number of Observations: 5

\begin{tabular}{|l|l|l|l|l|}
\hline Longitude & Latitude & City & Description \\
\hline-72.3388 & 18.5432 & Port-au-Prince & $\begin{array}{l}\text { (Scherer and Baltenweck, 1921): One tremor at 8 h. 31 p.m., direction NNE, } \\
\text { vertical component very sensibly felt, intensity IV accompanied by a loud } \\
\text { sound resembling heavy rain. The microseismometer was agitated for two } \\
\text { hours after the earthquake. }\end{array}$ \\
\hline-72.2864 & 18.5107 & Petionville & $\begin{array}{l}\text { (Scherer and Baltenweck, 1921): The same earthquake was felt at Petionvill } \\
\text { (weakly) at Furcy (very strong) at Thomazeau and Mirebalais (strong). }\end{array}$ \\
\hline-72.3062 & 18.4165 & Furcy & $\begin{array}{l}\text { (Scherer and Baltenweck, 1921): The same earthquake was felt at Petionvill } \\
\text { (weakly) at Furcy (very strong) at Thomazeau and Mirebalais (strong). }\end{array}$ \\
\hline-72.0943 & 18.6519 & Thomazeau & $\begin{array}{l}\text { (Scherer and Baltenweck, 1921): The same earthquake was felt at Petionvill } \\
\text { (weakly) at Furcy (very strong) at Thomazeau and Mirebalais (strong). }\end{array}$ \\
\hline-72.1040 & 18.8336 & Mirebalais & $\begin{array}{l}\text { (Scherer and Baltenweck, 1921): The same earthquake was felt at Petionvill } \\
\text { (weakly) at Furcy (very strong) at Thomazeau and Mirebalais (strong). }\end{array}$ \\
\hline
\end{tabular}

\section{February 10, 1910}

Time: 01:20:00 AM, Cavaillon local time (about 06:09:21 UTC)

Phenomenon Notes: Description originally published by the Port-au-Prince observatory for July-December 1909 (Scherer, $1910 \mathrm{a}$ )

Number of Observations: 1

\begin{tabular}{|l|l|l|l|l|}
\hline Longitude & Latitude & City & Description & Intensity \\
\hline-73.6552 & 18.2992 & Cavaillon & $\begin{array}{l}\text { (Scherer and Baltenweck, 1921): Tremor at 1h 20 m a.m., preceded by a } \\
\text { detonation like that of a cannon. }\end{array}$ \\
\hline
\end{tabular}

\section{May 11, 1910}




\begin{tabular}{|c|c|c|c|c|}
\hline \multicolumn{5}{|c|}{ May 11, 1910} \\
\hline \multicolumn{5}{|c|}{$\begin{array}{l}\text { Time: } 02: 41: 02 \text { AM, Port-au-Prince local mean time (07:30:23 UTC) } \\
\text { Phenomenon Notes: None } \\
\text { Number of Observations: } 12\end{array}$} \\
\hline Longitude & Latitude & City & Description & Intensity \\
\hline-70.7333 & 18.4532 & Azua & $\begin{array}{l}\text { (Scherer, 1912a): On May 11, 1910, a severe shock was felt at Azua and } \\
\text { Santo Domingo, and houses were cracked. The strongest part of the } \\
\text { earthquake occurred in the bay of Ocoa where the sea wall was broken. }\end{array}$ & $\begin{array}{l}\text { CHF(5) } \\
\text { SISF(7) } \\
\text { L\&S1995(6) } \\
\text { T\&R1977(6) }\end{array}$ \\
\hline-69.8877 & 18.4722 & Santo Domingo & $\begin{array}{l}\text { (Day, 1910): A severe earthquake shock was felt here at } 3 \text { o'clock this } \\
\text { morning. There was no loss of life nor damage to property in the city, but } \\
\text { reports from the interior have not been received. } \\
\text { (Scherer, 1912a): On May } 11,1910 \text {, a severe shock was felt at Azua and } \\
\text { Santo Domingo, and houses were cracked. }\end{array}$ & $\begin{array}{l}\mathrm{CHF}(5) \\
\operatorname{SISF}(7)\end{array}$ \\
\hline-70.3320 & 18.2799 & Bani & (Scherer, 1912a): It was equally strong at Bani, Christobal, and Barahona. & $\begin{array}{l}\text { CHF(5) } \\
\text { SISF(7) } \\
\text { L\&S1995(7) } \\
\text { T\&R1977(7) }\end{array}$ \\
\hline-71.0925 & 18.2051 & Barahona & (Scherer, 1912a): It was equally strong at Bani, Christobal, and Barahona. & $\begin{array}{l}\operatorname{CHF}(5) \\
\operatorname{SISF}(7) \\
\operatorname{L\& S1995(7)} \\
\text { T\&R1977(7) }\end{array}$ \\
\hline-70.1092 & 18.4135 & San Cristobal & (Scherer, 1912a): It was equally strong at Bani, Christobal, and Barahona. & $\begin{array}{l}\text { CHF(5) } \\
\text { SISF(7) } \\
\text { L\&S1995(7) } \\
\text { T\&R1977(7) }\end{array}$ \\
\hline-70.5327 & 19.2239 & La Vega & $\begin{array}{l}\text { (Scherer, 1912a): In the interior from La Vega to Cap Haitien and even to } \\
\text { Port-de Paix the shock was still very severe, while it was moderate at Port- } \\
\text { au-Prince. }\end{array}$ & $\begin{array}{l}\text { CHF(4) } \\
\text { SISF(6) } \\
\text { L\&S1995(6) } \\
\text { T\&R1977(6) }\end{array}$ \\
\hline-72.8370 & 19.9408 & Port-de-Paix & $\begin{array}{l}\text { (Scherer, 1910b): 2h. } 15 \text { m. am [local time] slight shaking, lasting two } \\
\text { seconds, direction E-W. }\end{array}$ & $\begin{array}{l}\text { CHF(3) } \\
\text { SISF(6) } \\
\text { L\&S1995(6) } \\
\text { T\&R1977(6) }\end{array}$ \\
\hline-72.2006 & 19.7616 & Cap Haitien & $\begin{array}{l}\text { (Scherer, 1910b): } 2 \mathrm{~h} 25 \mathrm{~m} \text { a.m. [local time] very strong shaking, SE to NW, } \\
\text { it appears that there were two shocks before. }\end{array}$ & $\begin{array}{l}\text { CHF(3) } \\
\text { SISF(6) } \\
\text { L\&S1995(6) } \\
\text { T\&R1977(6) }\end{array}$ \\
\hline-72.3388 & 18.5432 & Port-au-Prince & $\begin{array}{l}\text { (Scherer, 1910b): } 2 \text { h. } 41 \text { m. } 2 \text { s. [local time ] shock woke up several people } \\
\text { who were asleep, direction SE, lasting } 6 \text { seconds, intensity III [Rossi-Forel }\end{array}$ & $\begin{array}{l}\text { CHF(3) } \\
\text { SISF(5) }\end{array}$ \\
\hline
\end{tabular}




\begin{tabular}{|l|l|l|l|l|}
\hline \multicolumn{2}{|l|}{ May 11, 1910 } & & $\begin{array}{l}\text { Intensity ] all devices actuated, a pendulum swinging in the East to West } \\
\text { direction stopped. Seismograph [Omori-Bosch seismograph ] N-S 120 mm, } \\
\text { W-E 90 mm, vertical 15 mm. The shaking was followed by another very } \\
\text { weak one. Microseismic agitation several hours before and after the shock. }\end{array}$ \\
\hline-72.1892 & 18.4909 & Grande-Riviere & (Scherer, 1910b): 2 h 30 m. a.m. [local time] shock E-W. \\
\hline-72.2403 & 19.5257 & Dondon & (Scherer, 1910b): 2 h 30 m. a.m. [local time] shock E-W. \\
\hline-72.6929 & 19.4458 & Gonaives & (Scherer, 1910b): 2 h 25 m. a.m. [local time] 2 shocks. \\
\hline
\end{tabular}

\begin{tabular}{|c|c|c|c|c|}
\hline \multicolumn{5}{|c|}{ August 3, 1910} \\
\hline \multicolumn{5}{|c|}{$\begin{array}{l}\text { Time: } 05: 58: 45 \text { PM Port-au-Prince, local mean time (22:48:06 UTC) } \\
\text { Phenomenon Notes: None } \\
\text { Number of Observations: } 25\end{array}$} \\
\hline Longitude & Latitude & City & Description & Intensity \\
\hline-72.3062 & 18.4165 & Furcy & $\begin{array}{l}\text { (Scherer, 1910b): } 5 \text { h } 58 \mathrm{~m} \text { p.m. [local time] Based on the details of the } \\
\text { tremor, it was stronger than that in Port-au-Prince; intensity VI [Rossi-Forel } \\
\text { Intensity] direction SE, lasted } 50 \text { seconds. The vertical motion was so strong } \\
\text { that objects placed on the floor or table were raised and rattled. People } \\
\text { standing were trying to maintain their balance. It was the second phase that } \\
\text { was the strongest. }\end{array}$ & $\mathrm{CHF}(5)$ \\
\hline-72.2864 & 18.5107 & Petionville & $\begin{array}{l}\text { (Scherer, 1910b): Several successive tremors for one minute, direction E. } \\
\text { The main shock displaced furniture and unhooked doors, which denotes } \\
\text { strong vertical shaking, intensity VI [Rossi-Forel Intensity]. }\end{array}$ & $\begin{array}{l}\text { CHF(5) } \\
\text { WHB(6) }\end{array}$ \\
\hline-72.0630 & 18.5331 & Ganthier & (Scherer, 1910b): A strong tremor, S direction. & $\mathrm{CHF}(5)$ \\
\hline-72.0943 & 18.6519 & Thomazeau & $\begin{array}{l}\text { (Scherer, 1910b): Shake strong enough to ring the bell inside the clock tower } \\
\text { of the church. }\end{array}$ & $\mathrm{CHF}(5)$ \\
\hline-72.5345 & 18.2359 & Jacmel & $\begin{array}{l}\text { (Scherer, 1910b): The shaking started lightly growing stronger, direction SE, } \\
\text { lasting } 50 \text { seconds. The objects were thrown down and furniture displaced. } \\
\text { Four kilometers from the village, a retaining wall collapsed. }\end{array}$ & $\begin{array}{l}\text { CHF(5) } \\
\text { WHB(6) }\end{array}$ \\
\hline-72.6334 & 18.5111 & Leogane & $\begin{array}{l}\text { (Scherer, 1910b): A strong tremor, SE direction; lasted } 15 \text { seconds in the } \\
\text { city; the duration was longer in the heights. Heard a noise similar to that of } \\
\text { the collapse of a wall. }\end{array}$ & $\mathrm{CHF}(4)$ \\
\hline
\end{tabular}




\begin{tabular}{|c|c|c|c|c|}
\hline \multicolumn{5}{|c|}{ August 3, 1910} \\
\hline-72.3388 & 18.5432 & Port-au-Prince & $\begin{array}{l}\text { (Scherer, 1910b): } 5 \text { h } 58 \text { m } 45 \text { s. p.m. [local time] strong earthquake, intensity } \\
\text { V [Rossi-Forel Intensity] ESE direction, approximately one minute in } \\
\text { duration. Can distinguish on the seismogram } 6 \text { phases, the second of which } \\
\text { was stronger for the horizontal component; it was accompanied by a strong } \\
\text { vertical component [Omori-Bosch seismograph]. Small bells were tolled. The } \\
\text { strongest earthquake felt in Port-au-Prince since September 23, } 1887 \text {. }\end{array}$ & $\mathrm{CHF}(4)$ \\
\hline-73.3447 & 18.5028 & Anse-a-Veau & $\begin{array}{l}\text { (Scherer, 1910b): Strong shaking, E direction, lasting } 10 \text { seconds. The dishes } \\
\text { were broken. Have not felt for several years an earthquake so violent. }\end{array}$ & $\begin{array}{l}\text { CHF(4) } \\
\text { WHB(5) }\end{array}$ \\
\hline-72.8668 & 18.4315 & Petit-Goave & $\begin{array}{l}\text { (Scherer, 1910b): The tremor was felt by everyone, but people on horseback } \\
\text { did not notice it. }\end{array}$ & $\mathrm{CHF}(4)$ \\
\hline-73.8890 & 18.5671 & Corail & $\begin{array}{l}\text { (Scherer, 1910b): The first earthquake at } 5 \mathrm{~h} 58 \mathrm{~m} \text { p.m. [local time] direction } \\
\text { SE. The signs on many houses fell. The next shock was weaker. }\end{array}$ & $\mathrm{CHF}(4)$ \\
\hline-73.0366 & 18.8388 & Ile de la Gonave & $\begin{array}{l}\text { (Scherer, 1910b): A strong tremor overthrowing dishes and jugs of water, S } \\
\text { direction, lasting } 35 \text { seconds. The sea has remained calm as a lake. }\end{array}$ & $\begin{array}{l}\text { CHF(4) } \\
\text { WHB(5) }\end{array}$ \\
\hline-72.5126 & 18.7701 & Arcahaie & (Scherer, 1910b): Tremor weaker than in Gonaives, S direction. & $\mathrm{CHF}(4)$ \\
\hline-73.7500 & 18.1945 & Les Cayes & $\begin{array}{l}\text { (Scherer, 1910b): Two tremors felt by everyone, S direction. The first shock } \\
\text { started with vibrations became oscillatory and lasted } 11 \text { seconds, the second } \\
\text { oscillatory lasted } 15 \text { seconds. }\end{array}$ & $\mathrm{CHF}(4)$ \\
\hline-74.3959 & 18.3242 & Tiburon & (Scherer, 1910b): Strong tremor of short duration. & $\mathrm{CHF}(4)$ \\
\hline-72.6929 & 19.4458 & Gonaives & (Scherer, 1910b): Two tremors, lasting 30 seconds, E direction. & $\mathrm{CHF}(4)$ \\
\hline-73.3745 & 19.8052 & Mole-St. Nicholas & $\begin{array}{l}\text { (Scherer, 1910b): Strong tremor, NE direction. The tremor reminded of the } \\
\text { earthquake of September 23, } 1887 \text { when many houses were damaged. }\end{array}$ & $\mathrm{CHF}(3)$ \\
\hline
\end{tabular}




\begin{tabular}{|l|l|l|l|l|}
\hline \multicolumn{2}{|l|}{ August 3, 1910} & & V [Rossi-Forel Intensity ] E direction, a third weak tremor lasting 3 seconds. & (Scherer, 1910b): The tremor was relatively weak and passed unnoticed for \\
\hline-72.4308 & 19.8144 & Bayeux & $\begin{array}{l}\text { CHF(3) } \\
\text { three quarters of the population. }\end{array}$ \\
\hline-72.8370 & 19.9408 & Port-de-Paix & $\begin{array}{l}\text { (Scherer, 1910b): Two tremors were noticed of a total duration of 5 seconds. } \\
\text { The first was longer, SE direction, no sound was heard in the city but in the } \\
\text { countryside, the sound was similar to that of a storm. }\end{array}$ \\
\hline- & - & Mt. Holstein, Jamaica & $\begin{array}{l}\text { (Hall, 1922): Seismometer at Mt. Holstein, Jamaica recorded a light shock at } \\
\text { 6:00 PM [local time], from N.W., .022 [period?]. }\end{array}$ & - \\
\hline
\end{tabular}

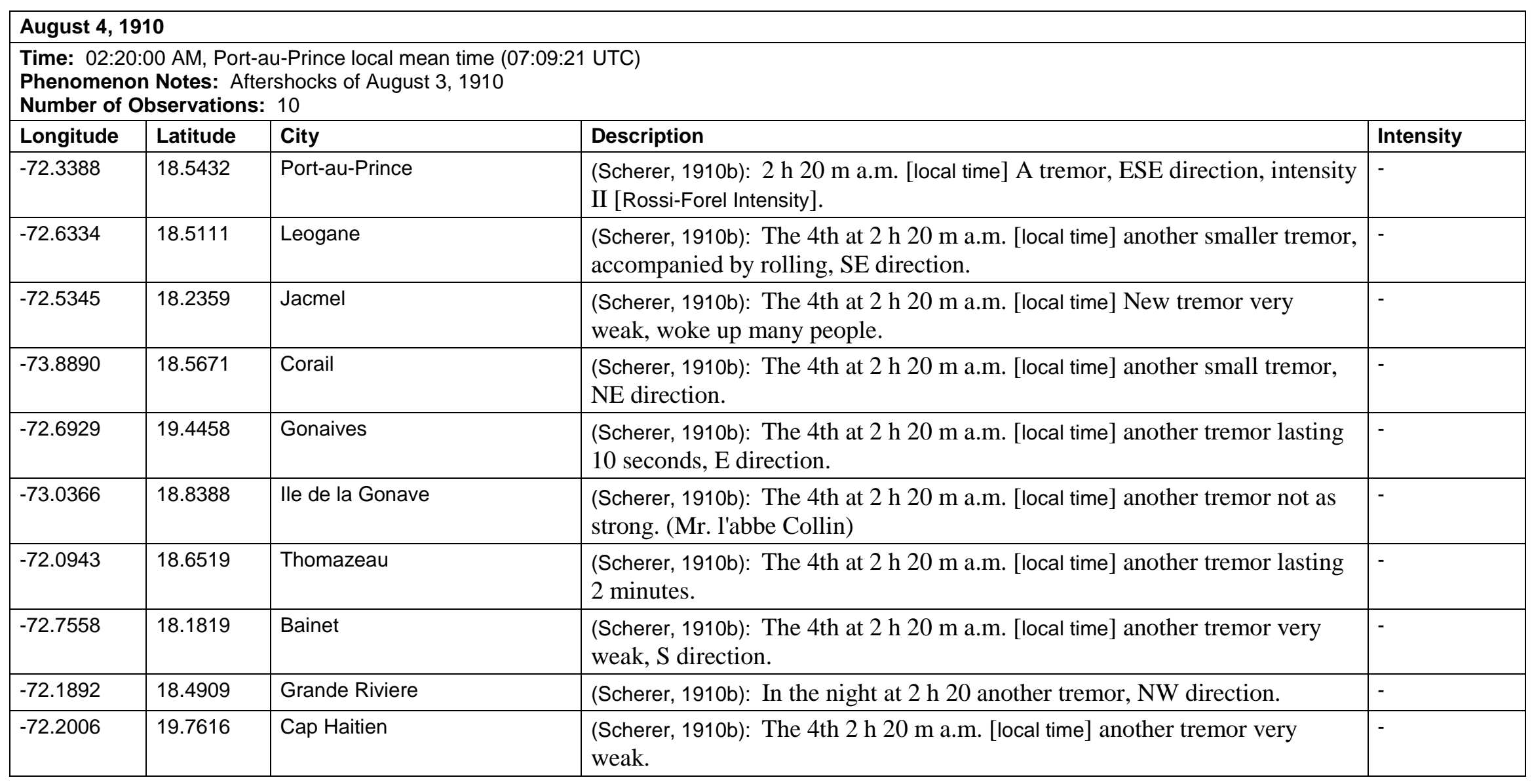




\begin{tabular}{|c|c|c|c|c|}
\hline \multicolumn{5}{|c|}{ October 6, 1911} \\
\hline \multicolumn{5}{|c|}{$\begin{array}{l}\text { Time: 10:16:12.0 UTC earthquake origin time; 05:28:30 AM, Port-au-Prince local mean time }(10: 17: 51 \text { UTC) } \\
\text { Land Surface Effects: In the village of Cotte-Plage that is now in Carrefour the train rails were shifted out of place. Landslides on the mountain Le Selle, near } \\
\text { Furcy. } \\
\text { Phenomenon Notes: }\left(-70.5^{\circ} \mathbf{W}, \mathbf{1 9 . 0 ^ { \circ }} \mathbf{N}\right) \text { depth }=\mathbf{0 . 0} \mathbf{~ k m , ~ M s ~}=\mathbf{6 . 8} \text { (Engdahl and Villaseñor, 2002) This earthquake most severely affected the central region of } \\
\text { Hispaniola and the aftershocks were mostly felt in that region. } \\
\text { Number of Observations: } 64\end{array}$} \\
\hline Longitude & Latitude & City & Description & Intensity \\
\hline-72.0107 & 19.1453 & Hinche & $\begin{array}{l}\text { (Le Nouvelliste,1911): This Friday the 6th, at } 6 \text { in the morning, we felt two } \\
\text { strong shocks from earthquakes. The first, the strongest I have felt since } \\
\text { living here, lasted a long time; the second much less, only a few seconds } \\
\text { long. *** The noise produced by the first tremor can be compared to, for } \\
\text { those that were outdoors, like the rolling by of a cavalry at a strong run; for } \\
\text { those who were indoors, the shock felt like when one is in a terrible train } \\
\text { wagon from the P.C.S, whose locomotive was at full speed to the plain of } \\
\text { Cul-de-Sac. *** and behold, at the moment I sign this letter (half past } \\
\text { noon) a new tremor just happened that lasted a few seconds. } \\
\text { (Scherer, 1912b): Lasted two minutes, S direction, intensity VIII to IX } \\
\text { [Rossi-Forel Intensity]. The tremors were jerky and finished with undulations. } \\
\text { A loud noise like a furious wind had preceded the shock. The church was } \\
\text { damaged, a large door that was blocked was unleveled and part of the } \\
\text { cornice in the south-east fell down. The large crucifix on the high altar and } \\
\text { many statues fell to the ground. A prison wall collapsed. We had some } \\
\text { difficulty standing. A horse with its rider fell to his knees. Second tremor at } \\
6 \text { h } 15 \text { m. Third at } 11 \text { h } 50 \text { m. Fourth at } 28 \text { minutes past noon (very strong } \\
\text { jerking). Fifth at } 7 \text { h } 30 \text { m and a sixth between } 10 \text { and } 11 \text { at night. Other } \\
\text { shocks after midnight and the following days. }\end{array}$ & $\begin{array}{l}\text { CHF(8) } \\
\text { WHB(6) } \\
\text { SISF(7) } \\
\text { L\&S1995(8) } \\
\text { T\&R1977(8) }\end{array}$ \\
\hline-71.7894 & 19.1634 & Cerca-La-Source & $\begin{array}{l}\text { (Scherer, 1912b): Lasted } 30 \text { seconds, SE direction, intensity IX [Rossi-Forel } \\
\text { Intensity]. Motion oscillatory and very fast. The church was strongly } \\
\text { constructed of stone, the arches of brick. The choir rotunda is greatly } \\
\text { damaged. Four arches are broken; the one to the North-East fell. The corner } \\
\text { of the front door, to the South-West is heavily cracked. The high altar } \\
\text { crucifix fell down. The rectory solidly built of stone is obliquely cracked in } \\
\text { ten locations, one inside wall is so cracked that it lets through daylight. The } \\
\text { inhabitants were frightened, the oldest not remembering an earthquake as } \\
\text { strong. The region was not yet inhabited in } 1887 \text {. Second tremor at half past }\end{array}$ & $\begin{array}{l}\mathrm{CHF}(7) \\
\text { WHB(6) } \\
\text { SISF(7) }\end{array}$ \\
\hline
\end{tabular}




\begin{tabular}{|c|c|c|c|c|}
\hline \multicolumn{5}{|c|}{ October 6, 1911} \\
\hline & & & $\begin{array}{l}\text { 10h. Third at half past noon. Fourth at } 2 \mathrm{~h} 30 \mathrm{~m} \text {. Fifth at } 7 \mathrm{~h} 25 \mathrm{~m} \text {. and a } \\
\text { sixth around } 10 \mathrm{~h} \text { at night. }\end{array}$ & \\
\hline-71.2325 & 18.8074 & San Juan de la Maguana & $\begin{array}{l}\text { (Scherer, 1912b): Lasted } 30 \text { seconds, intensity IX to X [Rossi-Forel Intensity]. } \\
\text { The parish church constructed of stone was reduced to ruins, much damage } \\
\text { to the cemetery. Individual losses were very considerable. Among the } \\
\text { houses damaged, the pharmacy Esperanza collapsed. The printing house of } \\
\text { the journal "Eco de Santome” was turned upside down. There were no } \\
\text { accidents to report except for a few bruises. But in Vallejuelo, a section of } \\
\text { San Juan, a woman and two children died as a result of the earthquake. In } \\
\text { the countryside to the East and West of San Juan, the tremors caused great } \\
\text { disruption. The earth opened in Palomino, situated between Loma Tina } \\
\text { ( } 3140 \text { meters of elevation) and San Juan, and there came a torrent. The } \\
\text { same for Las Matas or Fanfan, a crevasse brought forth a gush of water that } \\
\text { went to the river Macasia. Landslides are reported along the shores of } \\
\text { Yague del Sur and especially near Tubano. The tremors lasted for several } \\
\text { days in the area of San Juan. } \\
\text { (de Utrera, 1995): Very strong tremors on October 6, } 1911 \text { (named the } \\
\text { earthquake of San Bruno) [...] Completely ruined the church in San Juan de } \\
\text { la Maguana. }\end{array}$ & $\begin{array}{l}\text { CHF(7) } \\
\text { SISF(7) } \\
\text { L\&S1995(8) } \\
\text { T\&R1977(8) }\end{array}$ \\
\hline-71.9362 & 18.8303 & Las Caobas & $\begin{array}{l}\text { (Scherer, 1912b): Tomonde, Belladere. The houses are constructed of wood } \\
\text { and the panels between the posts are filled with limestone and mortar, others } \\
\text { with cob. Many panels fell or cracked. Cracks were found at the church. } \\
\text { Throughout the region, it is clear that it is the strongest earthquake felt since } \\
1842 \text {. }\end{array}$ & $\begin{array}{l}\text { CHF(7) } \\
\text { WHB(5) } \\
\text { SISF(6) } \\
\text { L\&S1995(5) } \\
\text { T\&R1977(5) }\end{array}$ \\
\hline-71.7074 & 19.0793 & Banica & $\begin{array}{l}\text { (Scherer, 1912a): The region disturbed on October 6th last is indeed the long } \\
\text { strip of land passing by Azua, San Juan, Cerca la Source, Banica, Hinche } \\
\text { and especially that which runs along near the Grande Hilera, commonly } \\
\text { called Cibao. }\end{array}$ & $\begin{array}{l}\text { CHF(8) } \\
\text { WHB(-) } \\
\text { SISF(7) }\end{array}$ \\
\hline-72.1892 & 18.4909 & Grande Riviere & $\begin{array}{l}\text { (Scherer, 1912b): The primary school was greatly damaged. The walls were } \\
\text { cracked, the arches were thrown down and crevasses fell from all the corner } \\
\text { crevices. The establishment has become uninhabitable. Intensity VII [Rossi- } \\
\text { Forel Intensity]. }\end{array}$ & $\begin{array}{l}\mathrm{CHF}(6) \\
\operatorname{SISF}(7)\end{array}$ \\
\hline
\end{tabular}




\begin{tabular}{|c|c|c|c|c|}
\hline \multicolumn{5}{|c|}{ October 6, 1911} \\
\hline & & & $\begin{array}{l}\text { the rectory fell, four slits on the walls. The gabled sacristy fell. Two houses } \\
\text { were greatly damaged. A table in the middle of a room turned around itself } \\
\text { and objects placed on top of it fell down. There was a big stir among the } \\
\text { inhabitants. Second tremor at } 30 \text { past noon. }\end{array}$ & \\
\hline-72.1260 & 19.6688 & Limonade & $\begin{array}{l}\text { (Scherer, 1912b): Lasted } 66 \text { seconds, S direction, intensity VI to VII [Rossi- } \\
\text { Forel Intensity]. Many objects fell over and broke. A floor tiled with bricks } \\
\text { well compiled overturned and had hundreds of breaks. About thirty slates of } \\
\text { the church fell. One house newly constructed is cracked. An old house } \\
\text { collapsed. A water mill was greatly disrupted. The tremor was weaker than } \\
\text { that of September 23, } 1887 \text {. The sound of the abyss was heard on October } 4 \\
\text { at half past } 5 \text { h in the morning from the NE direction. }\end{array}$ & $\mathrm{CHF}(6)$ \\
\hline-71.9207 & 19.4350 & Valliere & $\begin{array}{l}\text { (Scherer, 1912b): Many objects fell or detached from the walls. Some } \\
\text { sections of wall crumbled. Minimal damages. Intensity VI [Rossi-Forel } \\
\text { Intensity]. }\end{array}$ & $\mathrm{CHF}(6)$ \\
\hline-71.7223 & 19.5501 & Ouanaminthe & $\begin{array}{l}\text { (Scherer, 1912b): The majority of objects from the church fell or were } \\
\text { displaced. The rectory floor, built with thick walls, was cracked in several } \\
\text { places especially along the west edge. On the south edge of the church } \\
\text { tower has a large crack. A house wall, built on very solid ground suffered } \\
\text { more than the rectory. But the earthquake of September } 23,1887 \text { was } \\
\text { stronger that of October } 6 \text {. The church then was so strongly shaken that it } \\
\text { had to be strengthened. Intensity VII [Rossi-Forel Intensity]. }\end{array}$ & $\mathrm{CHF}(6)$ \\
\hline-69.8877 & 18.4722 & Santo Domingo & $\begin{array}{l}\text { (Scherer, 1912b): Lasted } 15 \text { to } 20 \text { seconds, W direction, intensity VII to VIII } \\
\text { [Rossi-Forel Intensity]. The tremor commenced with a soft oscillatory motion } \\
\text { accompanied by an underground noise, then immediately followed by } \\
\text { strong vibrations and very irregular. The bells from the public clock, the } \\
\text { Cathedral and Santa Clara were set into motion and rang. In the countryside } \\
\text { of San Carlos, many houses were damaged. At the Cathedral, the tower not } \\
\text { only suffered but also the church. Old crevasses opened further and it will } \\
\text { take considerable work to repair. Second tremor at half past noon. Third } \\
\text { around } 8 \mathrm{~h} \text { in the evening. }\end{array}$ & $\begin{array}{l}\mathrm{CHF}(6) \\
\operatorname{SISF}(7)\end{array}$ \\
\hline-70.3321 & 18.2799 & Bani & $\begin{array}{l}\text { (Scherer, 1912b): Violent shaking and very prolonged. They feared a } \\
\text { catastrophe. }\end{array}$ & $\mathrm{CHF}(6)$ \\
\hline-71.4178 & 18.4832 & Neyba & $\begin{array}{l}\text { (Scherer, 1912b): Yaguate. Strong tremor lasting } 8 \text { seconds, the same at } \\
\text { Bahardua and Neyba. }\end{array}$ & $\mathrm{CHF}(6)$ \\
\hline-70.7333 & 18.4532 & Azua & (Scherer, 1912b): Lasted 30 seconds, intensity IX [Rossi-Forel Intensity]. The & $\mathrm{CHF}(6)$ \\
\hline
\end{tabular}




\begin{tabular}{|c|c|c|c|c|}
\hline \multicolumn{5}{|c|}{ October 6, 1911} \\
\hline & & & $\begin{array}{l}\text { earthquake was composed of a series of oscillations and vibrations very } \\
\text { distinct, and all of a sudden the oscillations and vibrations were } \\
\text { simultaneous. The belfry and parish church were seriously damaged. A wall } \\
\text { of the training college and another of the former convent of the sisters of } \\
\text { mercy collapsed. Many trading houses built of stone and a pharmacy } \\
\text { subsequently had great material losses, estimated at several thousand } \\
\text { dollars. In the property of S. Oviedo there were a large number of cracks } \\
\text { where water gushed out in abundance. Several aftershocks were felt during } \\
\text { the day: at } 8 \text { h, and } 10 \text { h in the evening at about } 2 \text { o'clock in the morning. }\end{array}$ & $\operatorname{SISF}(7)$ \\
\hline-72.1395 & 19.1747 & Maissade & $\begin{array}{l}\text { (Scherer, 1912b): ESE direction, Tremor noticed for its long duration. Many } \\
\text { cracks appeared on houses made of cob [mud]. Nobody was scared. Abyssal } \\
\text { noise heard several times. }\end{array}$ & $\begin{array}{l}\text { CHF(6) } \\
\text { WHB(4) } \\
\text { SISF(6) } \\
\text { L\&S1995(5) } \\
\text { T\&R1977(5) }\end{array}$ \\
\hline-72.3340 & 19.3708 & St. Michel de l'Atalaye & $\begin{array}{l}\text { (Scherer, 1912b): Lasted } 30 \text { seconds, E direction, intensity V to VI [Rossi- } \\
\text { Forel Intensity]. The first tremor resembled a formidable gale. Loud cracking } \\
\text { sounds in the buildings. No damage. Heard the "sound of the abyss" in the } \\
\text { morning. }\end{array}$ & $\begin{array}{l}\text { CHF(4) } \\
\text { SISF(6) } \\
\text { L\&S1995(5) } \\
\text { T\&R1977(5) }\end{array}$ \\
\hline
\end{tabular}




\begin{tabular}{|c|c|c|c|c|}
\hline \multicolumn{5}{|c|}{ October 6, 1911} \\
\hline & & & $\begin{array}{l}\text { Forel Intensity] The chandelier in the church strongly swayed; objects fell. A } \\
\text { strong thud like that of a violent wind preceded the two tremors. }\end{array}$ & \\
\hline-72.3062 & 18.4165 & Furcy & $\begin{array}{l}\text { (Scherer, 1912b): (near Selle) the tremor was so strong that they could not } \\
\text { stand and had to lie on the floor. Objects placed on tables fell to the ground. } \\
\text { They talk about a rock fall on the side of la Selle. }\end{array}$ & $\begin{array}{l}\mathrm{CHF}(6) \\
\operatorname{SISF}(6)\end{array}$ \\
\hline-72.2273 & 18.5758 & Croix de Bouquets & $\begin{array}{l}\text { (Scherer, 1912b): E direction, intensity VI [Rossi-Forel Intensity]. Everyone } \\
\text { was frightened and got out of the houses. }\end{array}$ & $\mathrm{CHF}(6)$ \\
\hline-72.0943 & 18.6519 & Thomazeau & $\begin{array}{l}\text { (Scherer, 1912b): Parish pendulum clock stopped. Cracks in some walls, } \\
\text { tossing of church chandeliers, large cracks on the roofs. Intensity VI [Rossi- } \\
\text { Forel Intensity]. }\end{array}$ & $\mathrm{CHF}(6)$ \\
\hline-72.5126 & 18.7701 & Arcahaie & $\begin{array}{l}\text { (Scherer, 1912b): Lasted } 30 \text { seconds, E direction, Intensity VI [Rossi-Forel } \\
\text { Intensity]. Large cracks in structures. Great emotion in the church; they } \\
\text { remained on site. The clock oscillating E to W stopped. Great noises from } \\
\text { the trees. Motion resembled the roll of a ship. The very old thought of the } \\
\text { earthquakes of } 1842 \text { and } 1860 .\end{array}$ & $\mathrm{CHF}(6)$ \\
\hline-72.7000 & 19.1167 & Saint Marc & $\begin{array}{l}\text { (Scherer, 1912b): The first tremor at } 4 \mathrm{~h} \text { in the morning. The tremor at half } \\
\text { past } 5 \mathrm{~h} \text { lasted } 64 \text { seconds, S direction, Intensity VI [Rossi-Forel Intensity]. } \\
\text { Hard swaying of suspended objects. Minor cracks seemed to widen. A third } \\
\text { tremor } 26 \text { minutes past noon and a fourth one at } 7 \mathrm{~h} 25 \mathrm{~m} \text { in the evening. }\end{array}$ & $\mathrm{CHF}(6)$ \\
\hline-72.6933 & 19.2464 & Petit Riviere de l'Artibonite & $\begin{array}{l}\text { (Scherer, 1912b): E direction, tremor very strong but less than that of } \\
\text { September 23, } 1887 \text { because at that time the church had been heavily } \\
\text { cracked. This time the palace of King Christopher, an arch on the east fell. } \\
\text { The rest of the palace was already in ruins. Several shocks were felt in the } \\
\text { day. }\end{array}$ & $\mathrm{CHF}(5)$ \\
\hline-72.2004 & 18.8160 & Saut-D'Eau & $\begin{array}{l}\text { (Scherer, 1912b): Very strong tremors at } 5 \mathrm{~h} 28 \mathrm{~m} \text {, at } 26 \text { past noon at } 7 \mathrm{~h} 25 \mathrm{~m} \\
\text { and at } 10 \mathrm{~h} 45 \mathrm{~m} \text { in the evening. }\end{array}$ & $\mathrm{CHF}(6)$ \\
\hline-72.1040 & 18.8336 & Mirebalais & $\begin{array}{l}\text { (Scherer, 1912b): Two successive tremors lasting } 50 \text { seconds, the first very } \\
\text { long. SSW and NE directions, everything seemed to bounce in place, } \\
\text { Intensity VI to VII [Rossi-Forel Intensity]. Very large cracks on the buildings, } \\
\text { many walls damaged, a part of a wall fell down. Tremor preceded by a thud }\end{array}$ & $\mathrm{CHF}(6)$ \\
\hline
\end{tabular}




\begin{tabular}{|c|c|c|c|c|}
\hline \multicolumn{5}{|c|}{ October 6, 1911} \\
\hline & & & $\begin{array}{l}\text { sound. The people were scared and many say that this earthquake was the } \\
\text { strongest felt in a very long time. A second tremor at } 8 \mathrm{~h} 36 \mathrm{~m} \text { in the } \\
\text { morning almost as strong and the earlier one in the morning but of short } \\
\text { duration. A third one at } 10 \mathrm{~h} 30 \mathrm{~m} \text { (weak). Afterwards the inhabitants } \\
\text { continued to feel tremors during the day. }\end{array}$ & \\
\hline-72.6929 & 19.4458 & Gonaives & $\begin{array}{l}\text { (Scherer, 1912b): Lasted } 50 \text { seconds, SW direction, intensity VI [Rossi-Forel } \\
\text { Intensity]. Maximum intensity at about the } 10 \text { th second. Cracks on buildings, } \\
\text { objects fell, one house was damaged. Second tremor at } 30 \text { past noon, } \\
\text { intensity III [Rossi-Forel Intensity] lasting } 4 \text { seconds. A third tremor at } 7 \text { h } 35 \\
\text { m, intensity II [Rossi-Forel Intensity] lasting } 3 \text { seconds. A fourth tremor in the } \\
\text { night. }\end{array}$ & $\mathrm{CHF}(5)$ \\
\hline-72.4685 & 19.5974 & Plaisance & $\begin{array}{l}\text { (Scherer, 1912b): E direction, The walls that were damaged in 1887, was } \\
\text { damaged more. The rectory that was deteriorating is now quite damaged. }\end{array}$ & $\mathrm{CHF}(5)$ \\
\hline-72.4308 & 19.8144 & Bayeux & $\begin{array}{l}\text { (Scherer, 1912b): Lasted } 30 \text { seconds, NE direction, intensity VI [Rossi-Forel } \\
\text { Intensity]. Tremor was strong enough to the point it rang the village bell, } \\
\text { suspended on a fig tree branch. Second tremor at } 8 \mathrm{~h} 35 \mathrm{~m} \text { in the morning. } \\
\text { Third tremor at } 25 \text { minutes past noon. Movement undulating. }\end{array}$ & $\begin{array}{l}\mathrm{CHF}(6) \\
\mathrm{WHB}(5)\end{array}$ \\
\hline-72.2006 & 19.7616 & Cap Haitien & $\begin{array}{l}\text { (Scherer, 1912b): Lasted } 35 \text { to } 40 \text { seconds, SE direction, intensity VI to VII } \\
\text { [Rossi-Forel Intensity]. Furniture displaced, dishes on shelves fell down. } \\
\text { Ringing of bells in the house. Pendulum clocks stopped; large cracks on the } \\
\text { arches of the cathedral. A part of the wall that was badly constructed was } \\
\text { knocked down, fell to the SE. The wall is E to W. Many houses were } \\
\text { cracked. Everyone was very frightened and many lied down, the following } \\
\text { night they took shelter in the higher fortifications. In the cathedral panic } \\
\text { occurred; many people fell and got trampled. The tremor struck in a form } \\
\text { like a regular swing and very regular. Second tremor at } 25 \text { minutes past } \\
\text { noon. The third at } 7 \text { h } 35 \text { m; the latest tremors were felt by everyone. }\end{array}$ & $\begin{array}{l}\mathrm{CHF}(5) \\
\operatorname{SISF}(6)\end{array}$ \\
\hline
\end{tabular}




\begin{tabular}{|c|c|c|c|c|}
\hline \multicolumn{5}{|c|}{ October 6, 1911} \\
\hline & & & $\begin{array}{l}\text { Caracol a thud, appearing to come from offshore. The ship suddenly } \\
\text { stopped and was tossed around. The sea begins to boil as one sees when the } \\
\text { water becomes hot enough. There were no tidal waves at Fort Liberte. }\end{array}$ & \\
\hline-71.6507 & 19.8474 & Monte Cristi & (Scherer, 1912b): Three strong tremors of a long duration. & $\mathrm{CHF}(4)$ \\
\hline-70.6937 & 19.7971 & Puerto Plata & $\begin{array}{l}\text { (Scherer, 1912b): SSW direction, intensity V [Rossi-Forel Intensity], loud } \\
\text { cracking in buildings, pendulum clocks stopped, swaying of trees, no effect } \\
\text { on the walls and no noise. The population was alarmed. }\end{array}$ & $\mathrm{CHF}(4)$ \\
\hline-70.7075 & 19.4502 & Santiago de los Caballeros & $\begin{array}{l}\text { (Scherer, 1912b): Lasted one minute, intensity VI [Rossi-Forel Intensity]. } \\
\text { Second tremor very weak at } 20 \text { minutes past noon. }\end{array}$ & $\mathrm{CHF}(4)$ \\
\hline-70.4180 & 19.3796 & Salcedo & $\begin{array}{l}\text { (Scherer, 1912b): Great panic, they left their houses, intensity VI [Rossi-Forel } \\
\text { Intensity]. }\end{array}$ & $\mathrm{CHF}(4)$ \\
\hline-70.1099 & 19.1824 & Pimentel & (Scherer, 1912b): Violent tremor, few damages. & $\begin{array}{l}\mathrm{CHF}(5) \\
\mathrm{WHB}(4)\end{array}$ \\
\hline-70.5246 & 19.3929 & Moca & (Scherer, 1912b): Violent tremor, few damages. & $\begin{array}{l}\mathrm{CHF}(5) \\
\mathrm{WHB}(4)\end{array}$ \\
\hline-70.5327 & 19.2239 & La Vega & (Scherer, 1912b): Violent tremor, few damages. & $\begin{array}{l}\mathrm{CHF}(5) \\
\mathrm{WHB}(4)\end{array}$ \\
\hline-70.1531 & 19.0577 & Cotui & $\begin{array}{l}\text { (Scherer, 1912b): Lasted one minute, W direction, intensity V [Rossi-Forel } \\
\text { Intensity]. A tank shy of a few inches full of water spilled out East to West. } \\
\text { No damage. All the houses are wooden. The tremor was preceded by a faint } \\
\text { noise. A second tremor between } 11 \text { and noon. A third about } 8 \mathrm{~h} \text { in the } \\
\text { evening and a fourth one in the night. }\end{array}$ & $\mathrm{CHF}(5)$ \\
\hline-69.3390 & 19.2061 & Samana & (Scherer, 1912b): Strong tremor, lasting 8 seconds. & $\begin{array}{l}\mathrm{CHF}(4) \\
\operatorname{SISF}(6)\end{array}$ \\
\hline-69.3112 & 18.4526 & San Pedro de Macoris & $\begin{array}{l}\text { (Scherer, 1912b): A strong tremor without producing much emotion. } \\
\text { Intensity V to VI [Rossi-Forel Intensity]. }\end{array}$ & $\mathrm{CHF}(4)$ \\
\hline-74.2572 & 18.5613 & Moron & $\begin{array}{l}\text { (Scherer, 1912b): (near the Hotte) } 3 \text { distinct tremors a few seconds apart, the } \\
\text { second tremor very violent. The dew drops accumulated in the trees fell } \\
\text { like rain. Large cracks along the framework, some pieces of mortar fell. The } \\
\text { people came out of the houses. Intensity V [Rossi-Forel Intensity]. The second } \\
\text { is much weaker than that of August 3, 1910, but it was stronger to the } \\
\text { Sources-Chaudes between Moron and Tiburon. }\end{array}$ & $\begin{array}{l}\mathrm{CHF}(4) \\
\operatorname{SISF}(6)\end{array}$ \\
\hline-73.7500 & 18.1945 & Les Cayes & $\begin{array}{l}\text { (Scherer, 1912b): Two successive tremors, lasting } 15 \text { seconds, NE direction, } \\
\text { intensity IV [Rossi-Forel Intensity]. Stopped a pendulum clock; swaying of } \\
\text { water in a pond, cracking along framework. However, not everyone noticed }\end{array}$ & $\mathrm{CHF}(4)$ \\
\hline
\end{tabular}




\begin{tabular}{|c|c|c|c|c|}
\hline \multicolumn{5}{|c|}{ October 6, 1911} \\
\hline & & & the phenomenon. & \\
\hline-73.3971 & 18.2816 & Aquin & $\begin{array}{l}\text { (Scherer, 1912b): Lasting } 10 \text { seconds, N direction, intensity III to IV [Rossi- } \\
\text { Forel Intensity]. Not everyone noticed the tremor. Movement oscillatory. }\end{array}$ & $\mathrm{CHF}(3)$ \\
\hline-73.0861 & 18.4423 & Miragoane & $\begin{array}{l}\text { (Scherer, 1912b): Two distinct tremors, each lasting } 3 \text { seconds, NE direction, } \\
\text { intensity III [Rossi-Forel Intensity], they made people worry. }\end{array}$ & $\mathrm{CHF}(4)$ \\
\hline-72.7558 & 18.1819 & Bainet & $\begin{array}{l}\text { (Scherer, 1912b): Lasted one minute and a half, NE direction, intensity IV } \\
\text { [Rossi-Forel Intensity]. Cracks in frameworks, tremor noticed by everyone, } \\
\text { very strong in the hills. }\end{array}$ & $\mathrm{CHF}(5)$ \\
\hline-72.6334 & 18.5111 & Leogane & $\begin{array}{l}\text { (Scherer, 1912b): NE direction, intensity V [Rossi-Forel Intensity]. In the hills, } \\
\text { people were scared. }\end{array}$ & $\mathrm{CHF}(4)$ \\
\hline-72.5345 & 18.2359 & Jacmel & $\begin{array}{l}\text { (Scherer, 1912b): Lasted one minute, SE direction, intensity V [Rossi-Forel } \\
\text { Intensity]. Motion oscillatory; pendulum clock stopped, it worked E to W. } \\
\text { Furniture displaced slightly. Two old buildings collapsed, the earthquake } \\
\text { appears to be the strongest since } 1860 \text {. }\end{array}$ & $\mathrm{CHF}(4)$ \\
\hline-72.7275 & 19.5622 & Terre-Neuve & $\begin{array}{l}\text { (Scherer, 1912b): Weak tremor, E direction, intensity II to III [Rossi-Forel } \\
\text { Intensity]. Similarly in the Bay of Henne. }\end{array}$ & $\mathrm{CHF}(3)$ \\
\hline-73.3745 & 19.8052 & Mole-St. Nicholas & $\begin{array}{l}\text { (Scherer, 1912b): Bombarde to Jean-Rabel. Rather weak tremor, felt by } \\
\text { everyone, intensity III [Rossi-Forel Intensity]. }\end{array}$ & $\mathrm{CHF}(3)$ \\
\hline
\end{tabular}




\begin{tabular}{|c|c|c|c|c|}
\hline \multicolumn{5}{|c|}{ October 6, 1911} \\
\hline-72.8024 & 19.7799 & Bassin-Bleu & (Scherer, 1912b): Weak tremor and of short duration. & $\mathrm{CHF}(3)$ \\
\hline-72.8043 & 20.0507 & Ile de la Tortue & $\begin{array}{l}\text { (Scherer, 1912b): Lasted } 3 \text { seconds, S direction, intensity III [Rossi-Forel } \\
\text { Intensity]. }\end{array}$ & $\mathrm{CHF}(3)$ \\
\hline-72.6836 & 19.6699 & Gros-Morne & $\begin{array}{l}\text { (Scherer, 1912b): Lasting } 30 \text { seconds, S direction, intensity V [Rossi-Forel } \\
\text { Intensity] Large cracks on the structure of the village church which dates to } \\
\text { 1785. The faithful left it immediately. The isolated columns of a brick } \\
\text { church under construction did not suffer. The village church survived the } \\
\text { earthquake of 1842; however the building suffered then. The strongest } \\
\text { earthquake felt was that of September 23, 1887. The grand river was then } \\
\text { diverted from its course to Passe-Moulin. }\end{array}$ & $\mathrm{CHF}(4)$ \\
\hline-72.5230 & 19.8463 & Borgne & $\begin{array}{l}\text { (Scherer, 1912b): Lasted one minute, SW direction, intensity V [Rossi-Forel } \\
\text { Intensity]. Population terrified, intensity VI. }\end{array}$ & $\mathrm{CHF}(4)$ \\
\hline-74.3959 & 18.3242 & Tiburon & $\begin{array}{l}\text { (Scherer, 1912b): The tremor was preceded by a noise we thought was like a } \\
\text { gun in the distance, intensity III [Rossi-Forel Intensity]. }\end{array}$ & $\begin{array}{l}\text { CHF(3) } \\
\text { SISF(5) }\end{array}$ \\
\hline-74.4222 & 18.5605 & Dame-Marie & $\begin{array}{l}\text { (Scherer, 1912b): Lasted one minute. Noise from furniture and objects } \\
\text { hanging on the wall. Out in the countryside, the phenomenon was barely } \\
\text { observed. Intensity III [Rossi-Forel Intensity]. The last earthquake of this } \\
\text { intensity to date is January, } 1909 .\end{array}$ & $\mathrm{CHF}(3)$ \\
\hline-74.1657 & 18.2746 & Chardonnieres & $\begin{array}{l}\text { (Scherer, 1912b): A slight tremor, almost unnoticed. Intensity II [Rossi-Forel } \\
\text { Intensity]. }\end{array}$ & $\mathrm{CHF}(3)$ \\
\hline-74.1145 & 18.6446 & Jeremie & $\begin{array}{l}\text { (Scherer, 1912b): Tremor observed by a certain number of people, lasting } 30 \\
\text { seconds, E direction, intensity III [Rossi-Forel Intensity]. Much lower than } \\
\text { that of August 30, 1910. There is talk of a shock already felt the day before. }\end{array}$ & $\mathrm{CHF}(3)$ \\
\hline
\end{tabular}

\section{October 6, 1911 to March 5, 1912}

Time: Various times

Phenomenon Notes: Aftershocks of October 6, 1911; according to Branner (1912) up to March 5, 1912. Times are in Port-au-Prince local mean time, +04:49:21 Greenwich time.

Number of Observations: 16

\begin{tabular}{|l|l|l|l|l|}
\hline Longitude & Latitude & City & Description \\
\hline-72.0630 & 18.5331 & Ganthier & (Scherer, 1912b): Second tremor at 11:04.5 in the morning. \\
\hline-72.7000 & 19.1167 & Saint Marc & (Scherer, 1912b): A third at 12:26 PM and a fourth at 7:25 in the evening. & - \\
\hline-72.2004 & 18.8160 & Saut-D'Eau & (Scherer, 1912b): 12:26 PM, 7:25 PM, 10:45 PM. \\
\hline-72.1040 & 18.8336 & Mirebalais & (Scherer, 1912b): Second tremor at 8:36 AM, third at 10:30 PM, continued to & - \\
\hline
\end{tabular}




\begin{tabular}{|c|c|c|c|c|}
\hline \multicolumn{5}{|c|}{ October 6, 1911 to March 5, 1912} \\
\hline & & & feel tremors during the day. & \\
\hline-72.6929 & 19.4458 & Gonaives & $\begin{array}{l}\text { (Scherer, 1912b): Second tremor at 12:30PM, a third tremor at 7:35 PM a } \\
\text { fourth felt at night. }\end{array}$ & - \\
\hline-72.4308 & 19.8144 & Bayeux & (Scherer, 1912b): Second tremor at 8:35 AM, third at 12:25 PM. & - \\
\hline-72.4025 & 19.7066 & Limbe & $\begin{array}{l}\text { (Scherer, 1912b): Second tremor at 12:25 PM, third at \&:25 PM and fourth at } \\
\text { 11:30 PM. }\end{array}$ & - \\
\hline-72.2006 & 19.7616 & Cap Haitien & (Scherer, 1912b): Second tremor at 12:25 PM, third at 7:35 PM. & - \\
\hline-72.2403 & 19.5257 & Dondon & (Scherer, 1912b): Second tremor at 12:30 PM. & - \\
\hline-70.1531 & 19.0577 & Cotui & $\begin{array}{l}\text { (Scherer, 1912b): Second tremor between } 11 \text { and noon, a third around } 8 \text { at } \\
\text { night and a fourth at midnight. }\end{array}$ & - \\
\hline-69.8877 & 18.4722 & Santo Domingo & (Scherer, 1912b): Second tremor at 12:30 PM, third around 8 at night. & - \\
\hline-70.7333 & 18.4532 & Azua & $\begin{array}{l}\text { (Scherer, 1912b): Several aftershocks were felt during that day, at 8:00 AM, } \\
\text { 10:00 PM and at about } 2 \text { AM. }\end{array}$ & - \\
\hline-71.2325 & 18.8074 & San Juan de la Maguana & $\begin{array}{l}\text { (Scherer, 1912b): The tremors lasted for several days in the region of San } \\
\text { Juan. }\end{array}$ & - \\
\hline-71.7894 & 19.1634 & Cerca-La-Source & $\begin{array}{l}\text { (Scherer, 1912b): Second tremor at 10:30AM, a third at 12:30PM, a fourth at } \\
\text { 2:30 PM a fifth at 7:25 PM and a sixth around 10:00 PM at night. }\end{array}$ & - \\
\hline-72.0107 & 19.1453 & Hinche & $\begin{array}{l}\text { (Scherer, 1912b): Second tremor at 6:15 AM, third at 11:50 AM, a fourth at } \\
\text { 12:28 PM (very strong and jerky) a fifth at 7:30 PM and a sixth between } 10 \\
\text { and } 11 \text { at night. Several shocks after midnight and the following days after. }\end{array}$ & - \\
\hline- & - & Hispaniola (Haiti) & $\begin{array}{l}\text { (Branner, 1912): Other shocks occurred in Haiti as follows: September 7; } \\
\text { October 4, 8, 10, 13, 14, 15, 16, 18, 20, 23; November } 5 \text { and 28; December } \\
11 \text { and March 5. None of these however had an intensity greater than IV } \\
\text { [Rossi-Forel Intensity]. }\end{array}$ & - \\
\hline
\end{tabular}

\begin{tabular}{|c|c|c|c|c|}
\hline \multicolumn{5}{|c|}{ July 20, 1912} \\
\hline \multicolumn{5}{|c|}{$\begin{array}{l}\text { Time: } 08: 50: 00 \text { AM, Port-au-Prince local mean time (13:39:21 UTC) } \\
\text { Phenomenon Notes: Second earthquake at 09:03:00 AM (13:52:21 UTC). } \\
\text { Number of Observations: } 4\end{array}$} \\
\hline Longitude & Latitude & City & Description & Intensity \\
\hline-69.8877 & 18.4722 & Santo Domingo & $\begin{array}{l}\text { (Scherer, 1912c): According to the newspapers from Santo Domingo, the } \\
\text { bells of the cathedral and clock were set into motion. }\end{array}$ & $\begin{array}{l}\mathrm{CHF}(5) \\
\operatorname{SISF}(6.5)\end{array}$ \\
\hline-70.6937 & 19.7971 & Puerto Plata & (Scherer, 1912c): At 8h 50 m, intensity II [Rossi-Forel Intensity] lasting 5 & $\mathrm{CHF}(4)$ \\
\hline
\end{tabular}




\begin{tabular}{|l|l|l|l|}
\hline July 20, 1912 & & $\begin{array}{l}\text { seconds; a second tremor at 9h 4m intensity III [Rossi-Forel Intensity] } \\
\text { Direction SE. According to the newspapers from Santo Domingo, the bells } \\
\text { of the cathedral and clock were set into motion. }\end{array}$ \\
\hline-72.2403 & 19.5257 & Dondon & $\begin{array}{l}\text { (Scherer, 1912c): At 9h 3m light tremor lasting 4 to 5 seconds, intensity II } \\
\text { [Rossi-Forel Intensity]. }\end{array}$ \\
\hline-72.3388 & 18.5432 & Port-au-Prince & $\begin{array}{l}\text { (Scherer, 1912c): At 9h 3m weak tremor, intensity III [Rossi-Forel Intensity] E } \\
\text { direction; registered on the Omori-Bosch seismogram, July 20 at 8:50 to } \\
8: 54 \text { amplitude 7 mm and July 20 at 9:03 to 9:08 amplitude 56 mm: this } \\
\text { movement and the next were felt on the Dominican side. }\end{array}$ \\
\hline
\end{tabular}

\begin{tabular}{|c|c|c|c|c|}
\hline \multicolumn{5}{|c|}{ September 6, 1912} \\
\hline \multicolumn{5}{|c|}{$\begin{array}{l}\text { Time: } 11: 59: 00 \text { PM Port-au-Prince local mean time (04:48:21 UTC, September 7, 1912) } \\
\text { Phenomenon Notes: None } \\
\text { Number of Observations: } 29\end{array}$} \\
\hline Longitude & Latitude & City & Description & Intensity \\
\hline-72.0107 & 19.1453 & Hinche & $\begin{array}{l}\text { (Scherer, 1912c): Strong undulating tremor, direction SE, lasting } 25 \text { seconds. } \\
\text { The earthquake was less fearful than the one on October 6th last, because } \\
\text { the motion was not as jerky, intensity VI [Rossi-Forel Intensity]. }\end{array}$ & $\mathrm{CHF}(5)$ \\
\hline-72.1892 & 18.4909 & Grande Riviere & $\begin{array}{l}\text { (Scherer, 1912c): Strong vibrations enough to scare. A few cracks in a house, } \\
\text { intensity VII [Rossi-Forel Intensity]. At Bahon, strong tremor. }\end{array}$ & $\mathrm{CHF}(4)$ \\
\hline-72.3340 & 19.3708 & St. Michel de l'Atalaye & $\begin{array}{l}\text { (Scherer, 1912c): Strong tremor, direction N, statue fell and broke, house } \\
\text { cracked, intensity VII [Rossi-Forel Intensity]. }\end{array}$ & $\mathrm{CHF}(5)$ \\
\hline-72.4025 & 19.7066 & Limbe & $\begin{array}{l}\text { (Scherer, 1912c): Strong tremor, direction E, lasting } 25 \text { seconds. At the } \\
\text { beginning and at the end the motion was oscillatory and strong vibrations in } \\
\text { the middle for } 10 \text { seconds. Damages unimportant, the ancient cracks in the } \\
\text { church grew larger, intensity VII [Rossi-Forel Intensity]. }\end{array}$ & $\mathrm{CHF}(5)$ \\
\hline-71.7223 & 19.5501 & Ouanaminthe & $\begin{array}{l}\text { (Scherer, 1912c): Two tremors seeming to be stronger than that of October } \\
\text { 6th last, the shaking was regular and undulating and there were no damages, } \\
\text { direction E, intensity VI [Rossi-Forel Intensity]. }\end{array}$ & $\mathrm{CHF}(4)$ \\
\hline-74.1145 & 18.6446 & Jeremie & (Scherer, 1912c): One could distinguish two successive shocks; the first & $\mathrm{CHF}(4)$ \\
\hline
\end{tabular}




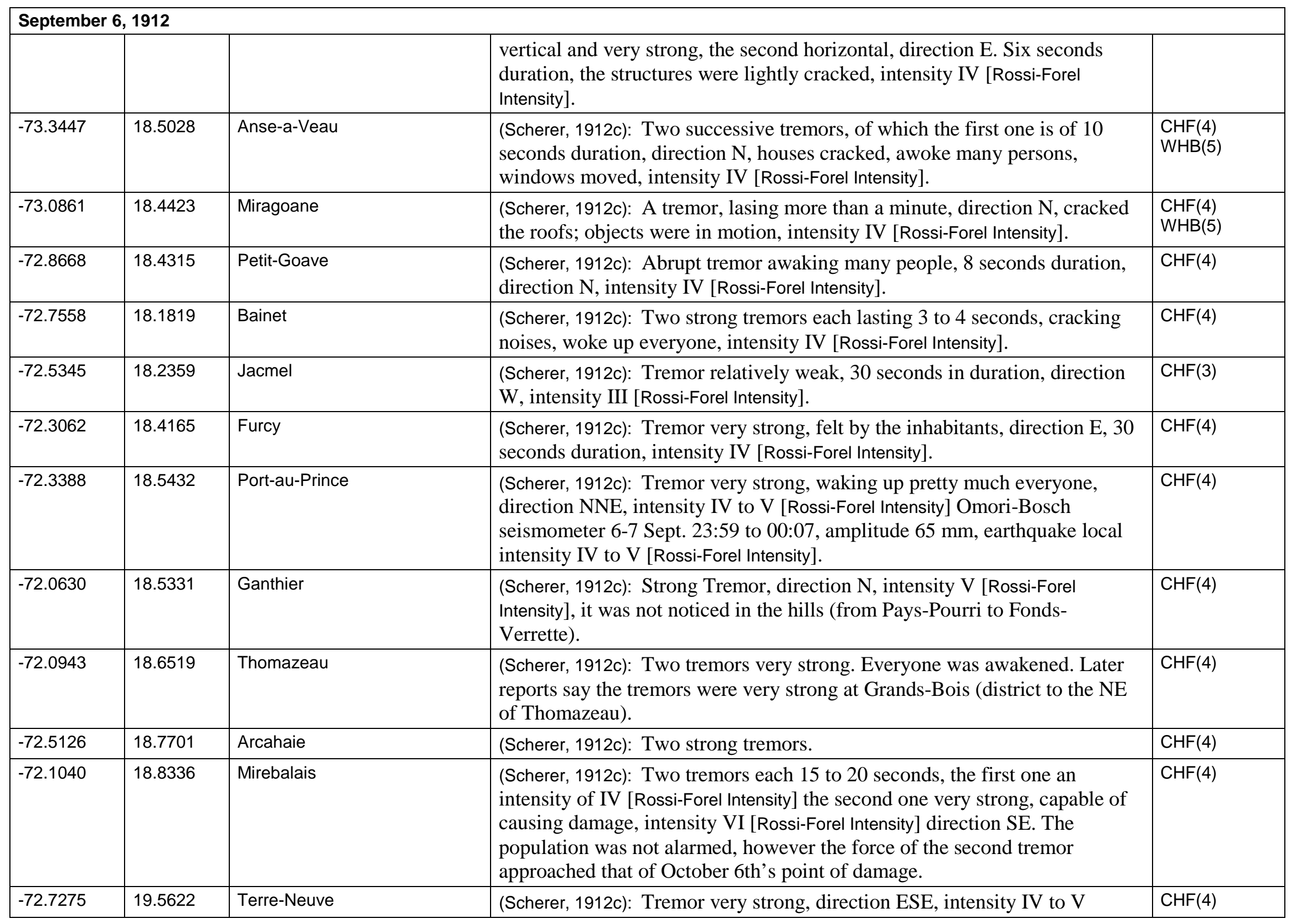




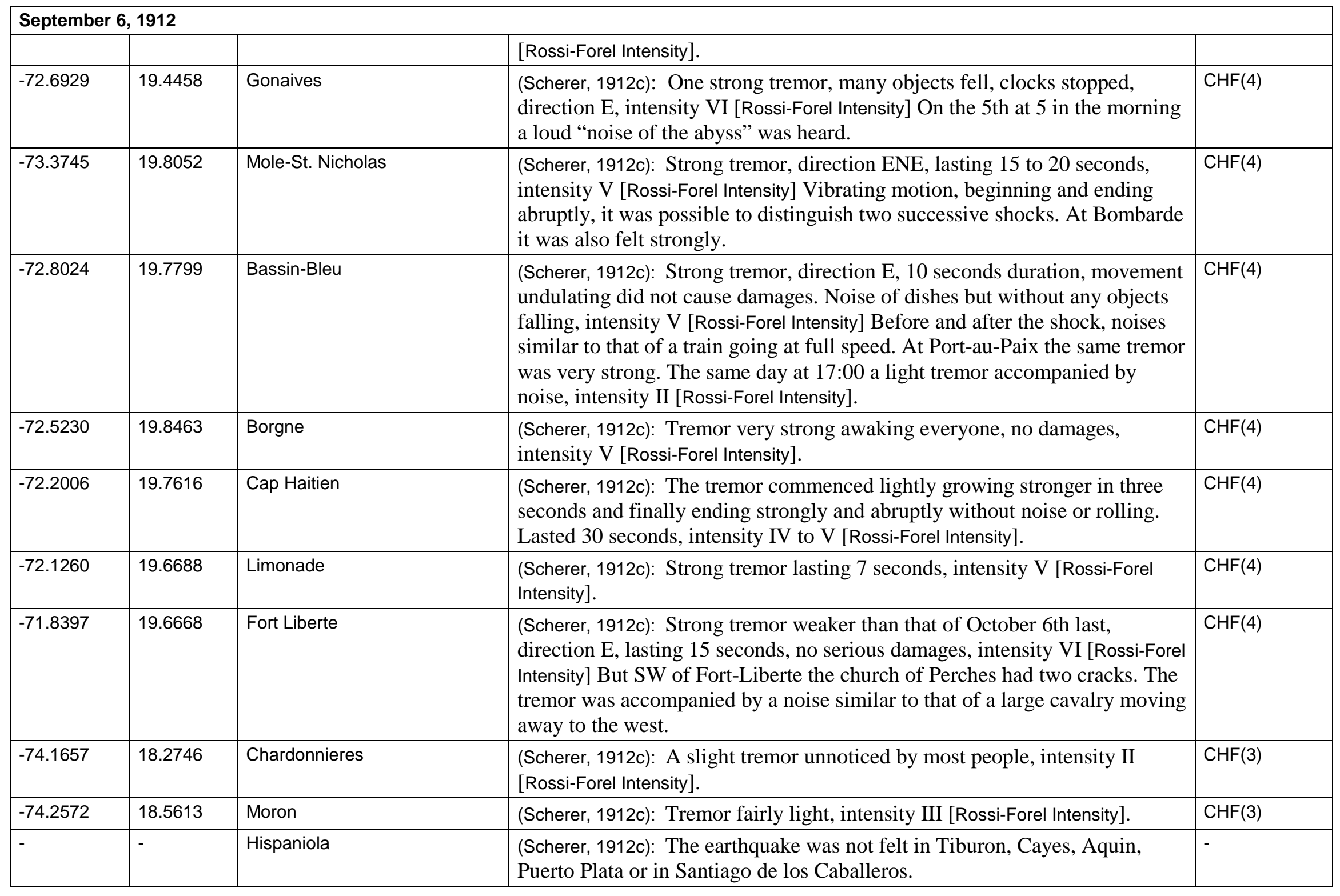

September 6, 1912 to September 13, 1912 


\begin{tabular}{|c|c|c|c|c|}
\hline \multicolumn{5}{|c|}{ September 6, 1912 to September 13, 1912} \\
\hline \multicolumn{5}{|c|}{$\begin{array}{l}\text { Time: Various times } \\
\text { Phenomenon Notes: Aftershocks of September 6, } 1912 . \\
\text { Number of Observations: } 3\end{array}$} \\
\hline Longitude & Latitude & City & Description & Intensity \\
\hline-72.6929 & 19.4458 & Gonaives & $\begin{array}{l}\text { (Scherer, 1912c): September 7, 15:00, distinct tremor lasting } 5 \text { seconds } \\
\text { intensity III [Rossi-Forel Intensity], September 8, one weak tremor in the } \\
\text { morning. }\end{array}$ & - \\
\hline-72.5126 & 18.7701 & Arcahaie & $\begin{array}{l}\text { (Scherer, 1912c): September 9, light tremor at 17:00 and on September } 10 \text { at } \\
\text { 11:00. }\end{array}$ & - \\
\hline-72.8024 & 19.7799 & Bassin-Bleu & $\begin{array}{l}\text { (Scherer, 1912c): September 13, at Port-au-Paix and Bassin Bleu, one light } \\
\text { tremor at 6:00, lasting } 2 \text { seconds. }\end{array}$ & - \\
\hline
\end{tabular}

\section{April 24, 1916}

Time: 04:26:42 UTC earthquake origin time; April 23, 1916, 11:30:00 PM, Santo Domingo local time (about 04:30:00 UTC, April 24, 1916)

Phenomenon Notes: $\left(-68.0^{\circ} \mathbf{W}, \mathbf{1 8 . 5 ^ { \circ }} \mathrm{N}\right)$ depth $=\mathbf{8 0} \mathrm{km}, \mathbf{m b}=\mathbf{7 . 0}$ (Engdahl and Villaseñor, 2002). Magnitude intensities reported from the Bulletin are Rossi-Forel Intensities. The Port-au-Prince observatory recorded this earthquake with an Omori-Bosch seismometer. The P-wave arrival was at 04:24:54 UTC (Scherer, 1916). The seismic station in Vieques, Puerto Rico also recorded this earthquake with a Pn-wave arrival at 04:27:23 UTC (Humphreys ,1917).

Number of Observations: 25

\begin{tabular}{|c|c|c|c|c|}
\hline Longitude & Latitude & City & Description & Intensity \\
\hline-69.7923 & 18.9458 & Boya & $\begin{array}{l}\text { (Scherer, 1916): At Boya, south of the Central Cordillera, their church was } \\
\text { ruined. }\end{array}$ & $\mathrm{CHF}(6)$ \\
\hline-69.6370 & 18.7520 & Bayaguana & $\begin{array}{l}\text { (Scherer, 1916): A little further south at Guerra and Bayaguana the churches } \\
\text { are almost completely destroyed, Intensity IX. }\end{array}$ & $\mathrm{CHF}(6)$ \\
\hline-69.8877 & 18.4722 & Santo Domingo & $\begin{array}{l}\text { (New York Times, 1916b): Santo Domingo, Dominican Republic April 24, A } \\
\text { severe earthquake occurred here at 11:30 o'clock last night. No damage was } \\
\text { done. } \\
\text { (Pittsburgh Press, 1916): Severe earthquake shocks caused heavy damage } \\
\text { throughout the island of Haiti last night and early today. Communication } \\
\text { with interior points was broken off and it is feared there has been heavy loss } \\
\text { of life. The tremors began before midnight but the most severe shock } \\
\text { occurred early today. Many houses were razed. The government buildings } \\
\text { were shaken. } \\
\text { (Scherer, 1916): In Santo Domingo the intensity seems to have been VIII. } \\
\text { There were cracks in the walls of many buildings (the Church of Mercedes, }\end{array}$ & $\begin{array}{l}\text { CHF(5) } \\
\text { SISF(8.5) }\end{array}$ \\
\hline
\end{tabular}




\begin{tabular}{|c|c|c|c|c|}
\hline \multicolumn{5}{|c|}{ April 24, 1916} \\
\hline & & & $\begin{array}{l}\text { a former Dominican convent and the Government Palace). The bells were } \\
\text { ringing in the churches. } \\
\text { (Taber, 1922): The earthquake of April 23, 1916, which had an intensity of } \\
\text { VIII-IX in the eastern part of Santo Domingo, seems to have originated near } \\
\text { the inner margin of the coastal plain or the southern flank of the Cordillera } \\
\text { Central, but farther west than the epicenter area of the earthquake of } 1882 \text {. }\end{array}$ & \\
\hline-70.6937 & 19.7971 & Puerto Plata & $\begin{array}{l}\text { (Scherer, 1916): Between } 23 \mathrm{~h} 49 \mathrm{~m} \text { and } 23 \mathrm{~h} 50 \mathrm{~m} \text { one observes three } \\
\text { successive tremors: the middle one lasted } 25 \text { seconds, intensity VI; direction } \\
\text { ENE. At the Cumbre Tunnel (Monte Cristi Mountain Chain) NNE direction. } \\
\text { There were no damages at Puerto-Plata. }\end{array}$ & $\mathrm{CHF}(4)$ \\
\hline-72.1260 & 19.6688 & Limonade & $\begin{array}{l}\text { (Scherer, 1916): A strong tremor, Intensity V, direction NE lasting } 30 \\
\text { seconds. }\end{array}$ & $\mathrm{CHF}(4)$ \\
\hline-72.2006 & 19.7616 & Cap Haitien & $\begin{array}{l}\text { (Scherer, 1916): Strong tremor, intensity V; direction E, lasting } 10 \text { seconds. } \\
\text { Tremor felt at Bayeux. }\end{array}$ & $\mathrm{CHF}(4)$ \\
\hline-72.8370 & 19.9408 & Port-de-Paix & $\begin{array}{l}\text { (Scherer, 1916): Fairly strong tremor, intensity IV, creaking of wood, no } \\
\text { objects overthrown, direction E. }\end{array}$ & $\mathrm{CHF}(4)$ \\
\hline-72.5504 & 19.6652 & Pilate & $\begin{array}{l}\text { (Scherer, 1916): Tremor well felt, resembling a roll, intensity IV, lasting } 20 \\
\text { seconds, direction ENE. }\end{array}$ & $\mathrm{CHF}(4)$ \\
\hline-72.6929 & 19.4458 & Gonaives & $\begin{array}{l}\text { (Scherer, 1916): One strong tremor, intensity V, direction E, people began to } \\
\text { worry, lasting } 35 \text { seconds. }\end{array}$ & $\mathrm{CHF}(4)$ \\
\hline-72.1040 & 18.8336 & Mirebalais & $\begin{array}{l}\text { (Scherer, 1916): One strong tremor composed of many oscillations from E to } \\
\text { W, intensity V to VI. }\end{array}$ & $\mathrm{CHF}(4)$ \\
\hline-72.0943 & 18.6519 & Thomazeau & $\begin{array}{l}\text { (Scherer, 1916): The bells, placed } 3 \text { meters from the ground, sounded, } \\
\text { intensity Vi to VII. }\end{array}$ & $\mathrm{CHF}(4)$ \\
\hline-72.3062 & 18.4165 & Furcy & $\begin{array}{l}\text { (Scherer, 1916): All of the inhabitants were awoken, objects fell, Intensity } \\
\text { VI. }\end{array}$ & $\begin{array}{l}\mathrm{CHF}(4) \\
\mathrm{WHB}(5)\end{array}$ \\
\hline-72.3388 & 18.5432 & Port-au-Prince & $\begin{array}{l}\text { (Scherer, 1916): One strong tremor, intensity V to VI, direction NE, lasting } \\
50 \text { seconds, Omori-Bosch recorded P at 04:24:54 GMT. }\end{array}$ & $\mathrm{CHF}(4)$ \\
\hline-72.5345 & 18.2359 & Jacmel & $\begin{array}{l}\text { (Scherer, 1916): A fairly strong tremor, intensity IV, direction N. One could } \\
\text { distinguish three successive tremors. }\end{array}$ & $\mathrm{CHF}(4)$ \\
\hline-72.7558 & 18.1819 & Bainet & $\begin{array}{l}\text { (Scherer, 1916): A fairly strong tremor, many people were woken up. The } \\
\text { earthquake does not appear to have been felt on the rest of the southern } \\
\text { peninsula. }\end{array}$ & $\mathrm{CHF}(4)$ \\
\hline
\end{tabular}




\begin{tabular}{|c|c|c|c|c|}
\hline \multicolumn{5}{|c|}{ April 24, 1916} \\
\hline-71.1462 & 21.4674 & Grand Turks Island & $\begin{array}{l}\text { (Robson, } 1964 \text { quoting Barbados Globe, Apr. 25, 1916): At 11:40 pm, a shock of } \\
\text { marked intensity. } \\
\text { (Tomblin and Robson, } 1977 \text { quoting Daily Chronicle, Apr. 26, 1916): 23:40 local } \\
\text { time, A shock of marked intensity followed by a weaker one which lasted for } \\
\text { several minutes. }\end{array}$ & $\begin{array}{l}\text { CHF(3) } \\
\text { SISF(5) } \\
\text { R1964(5) }\end{array}$ \\
\hline-66.6141 & 18.0115 & Ponce, Puerto Rico & $\begin{array}{l}\text { (Tomblin and Robson, } 1977 \text { quoting Barbados Globe, Apr. 25, 1916): 00:30 A } \\
\text { prolonged shock. }\end{array}$ & $\mathrm{CHF}(3)$ \\
\hline-66.1057 & 18.4665 & San Juan, Puerto Rico & $\begin{array}{l}\text { (New York Times, 1916a): San Juan P.R, April } 24 \text { - An earthquake shock } \\
\text { lasting from six to ten seconds was felt here early this morning, shortly after } \\
\text { midnight. No damage is reported. } \\
\text { (Robson, 1964, quoting Port of Spain Gazette, Apr. 26, 1916): At 12:30 am, a } \\
\text { severe shock. } \\
\text { (Humphreys, 1917): Two shocks felt, } 10 \text { seconds duration, Timbers creaked. }\end{array}$ & $\begin{array}{l}\text { CHF(4) } \\
\text { SISF(5) } \\
\text { R1964(5) }\end{array}$ \\
\hline-66.8777 & 18.2950 & Lares, Puerto Rico & (Humphreys, 1917): One shock felt, 30 seconds duration, partitions creaked. & $\mathrm{CHF}(4)$ \\
\hline-66.2664 & 18.1391 & Aibonito, Puerto Rico & (Humphreys, 1917): Three shocks felt, rumbling sound, doors moved. & $\mathrm{CHF}(4)$ \\
\hline-67.0250 & 18.5017 & Isabela, Puerto Rico & (Humphreys, 1917): One shock felt, walls cracked slightly. & $\mathrm{CHF}(4)$ \\
\hline-65.4248 & 18.1281 & Vieques, Puerto Rico & $\begin{array}{l}\text { (Humphreys ,1917): Recorded Pn at 4:27:23 GMT, reported to have been felt } \\
\text { in Vieques, PR. }\end{array}$ & $\begin{array}{l}\text { CHF(3) } \\
\text { SISF(2.5) }\end{array}$ \\
\hline- & - & $\begin{array}{l}\text { Georgetown University, } \\
\text { Washington D.C., U.S. }\end{array}$ & $\begin{array}{l}\text { (Evening News, 1916): Washington, April } 24-\text { Two severe earth vibrations } \\
\text { estimated to be } 1600 \text { miles distant from Washington, were recorded by the } \\
\text { seismograph at the Georgetown University. The first shock was recorded at } \\
\text { 11:31 o'clock last night, the vibrations continuing until 12:07 o'clock this } \\
\text { morning. The second and most severe shock occurred at 3:06 o'clock this } \\
\text { morning and continued until 4:15 o'clock. The second vibration was so } \\
\text { intense that the needles of the seismograph were loosened. }\end{array}$ & - \\
\hline
\end{tabular}




\begin{tabular}{|c|c|c|c|c|}
\hline \multicolumn{5}{|c|}{ January 15, 1922} \\
\hline \multicolumn{5}{|c|}{$\begin{array}{l}\text { Time: 06:37:58 UTC, 01:38:00 AM Port-au-Prince, 75th Meridian Time } \\
\text { Phenomenon Notes: Intensities inside the descriptions were assigned by the Port-au-Prince observatory and are Rossi-Forel Intensities (Scherer and Baltenweck, } \\
\text { 1922). } \\
\text { Number of Observations: } 11\end{array}$} \\
\hline Longitude & Latitude & City & Description & Intensity \\
\hline-73.7500 & 18.1945 & Les Cayes & $\begin{array}{l}\text { (Scherer and Baltenweck, 1922): One very strong tremor that woke up } \\
\text { everyone, intensity of V to VI duration of } 4 \text { seconds, direction S SE. The } \\
\text { earthquake was felt at Canot, } 32 \text { km to the NW of Les Cayes at l'Ile a } \\
\text { Vaches, and even some sailors say at sea. The houses were tremendously } \\
\text { cracked, even those with reinforced concrete, many clocks were stopped, } \\
\text { bottles and jars from the pharmacy were hitting each other. People had to } \\
\text { abandon their homes. The main shock was preceded by a less violent jerk. }\end{array}$ & - \\
\hline-72.3388 & 18.5432 & Port-au-Prince & $\begin{array}{l}\text { (Scherer and Baltenweck, 1922): At } 1 \mathrm{~h} 38 \mathrm{~m} \text { a.m. A very strong tremor, } \\
\text { minor direction East, major direction South, duration } 40 \text { seconds, intensity } \\
\text { IV to V. The tremor was felt at Petionville and at Furcy and within the } \\
\text { plain Cul-de-Sac close to the Selle. }\end{array}$ & - \\
\hline-73.3447 & 18.5028 & Anse-a-Veau & $\begin{array}{l}\text { (Scherer and Baltenweck, 1922): One very strong tremor, intensity V, duration } \\
\text { of } 10 \text { seconds, direction E. The motion began with sharp vibrations, objects } \\
\text { fell down. The tremor was followed by two more tremors at } 5 \text { minute } \\
\text { intervals. }\end{array}$ & - \\
\hline-73.0861 & 18.4423 & Miragoane & $\begin{array}{l}\text { (Scherer and Baltenweck, 1922): One strong tremor, lasting about } 30 \text { seconds, } \\
\text { direction S. The movements had very large amplitudes, followed by two } \\
\text { weak oscillations separately. Telegram from Mr. A. Tovar. }\end{array}$ & - \\
\hline-74.1145 & 18.6446 & Jeremie & $\begin{array}{l}\text { (Scherer and Baltenweck, 1922): Two very strong tremors, creaking doors, } \\
\text { intensity IV to V. }\end{array}$ & - \\
\hline-72.8668 & 18.4315 & Petit Goave & $\begin{array}{l}\text { (Scherer and Baltenweck, 1922): One strong tremor, intensity IV to V, } \\
\text { duration } 6 \text { seconds. }\end{array}$ & - \\
\hline-72.7558 & 18.1819 & Bainet & $\begin{array}{l}\text { (Scherer and Baltenweck, 1922): Two strong tremors, together lasting } 20 \\
\text { seconds, intensity IV. }\end{array}$ & - \\
\hline-72.5345 & 18.2359 & Jacmel & $\begin{array}{l}\text { (Scherer and Baltenweck, 1922): One very strong tremor, intensity IV } \\
\text { direction W. }\end{array}$ & - \\
\hline-72.6978 & 19.1081 & St. Marc & $\begin{array}{l}\text { (Scherer and Baltenweck, 1922): One tremor of intensity III, duration } 4 \\
\text { seconds. }\end{array}$ & - \\
\hline-72.6929 & 19.4458 & Gonaives & $\begin{array}{l}\text { (Scherer and Baltenweck, 1922): One light tremor at } 1 \mathrm{~h} 38 \mathrm{~m} \text { a.m., intensity III } \\
\text { direction W, duration } 40 \text { seconds. }\end{array}$ & - \\
\hline
\end{tabular}




\begin{tabular}{|l|l|l|l|l|}
\hline-74.3959 & 18.3242 & Tiburon & (Scherer and Baltenweck, 1922): The earthquake was not noticed. \\
\hline
\end{tabular}

\begin{tabular}{|c|c|c|c|c|}
\hline \multicolumn{5}{|c|}{ November 4, 1922} \\
\hline \multicolumn{5}{|c|}{$\begin{array}{l}\text { Time: } 05: 35: 11 \text { UTC, 00:35:00 AM Port-au-Prince local time, 75th Meridian Time } \\
\text { Phenomenon Notes: Intensity values in the descriptions were assigned by the Port-au-Prince observatory and are Rossi-Forel Intensities (Scherer and Baltenweck, } \\
\text { 1923). } \\
\text { Number of Observations: } 18\end{array}$} \\
\hline Longitude & Latitude & City & Description & Intensity \\
\hline-72.3388 & 18.5432 & Port-au-Prince & $\begin{array}{l}\text { (Scherer and Baltenweck, 1923): At midnight } 35 \mathrm{~m} \text {. One very strong tremor } \\
\text { that woke up everyone causing fear. Intensity VI, duration } 15 \text { seconds. } \\
\text { Remarkable vertical component, general barking of dogs. }\end{array}$ & - \\
\hline-72.2864 & 18.5107 & Petionville & $\begin{array}{l}\text { (Scherer and Baltenweck, 1923): At the same hour. One very strong tremor, } \\
\text { intensity VI, general awakening of those asleep, duration } 10 \text { seconds. } \\
\text { Noises from the walls. The earthquake was preceded by two loud } \\
\text { subterranean noises. }\end{array}$ & - \\
\hline-72.0943 & 18.6519 & Thomazeau & (Scherer and Baltenweck, 1923): One strong tremor, intensity V. & - \\
\hline-72.5345 & 18.2359 & Jacmel & $\begin{array}{l}\text { (Scherer and Baltenweck, 1923): One quite strong tremor, intensity IV } \\
\text { duration of } 6 \text { seconds. }\end{array}$ & - \\
\hline-72.7558 & 18.1819 & Bainet & $\begin{array}{l}\text { (Scherer and Baltenweck, 1923): One strong tremor, intensity IV to V duration } \\
6 \text { seconds, direction E. }\end{array}$ & - \\
\hline-73.3971 & 18.2816 & Aquin & $\begin{array}{l}\text { (Scherer and Baltenweck, 1923): One strong tremor, intensity IV to V duration } \\
6 \text { seconds, direction E. }\end{array}$ & - \\
\hline-73.7500 & 18.1945 & Les Cayes & $\begin{array}{l}\text { (Scherer and Baltenweck, 1923): Two tremors felt by many persons with a } \\
\text { duration of } 2 \text { to } 4 \text { seconds, intensity III to IV. }\end{array}$ & - \\
\hline-74.1145 & 18.6446 & Jeremie & $\begin{array}{l}\text { (Scherer and Baltenweck, 1923): Vibrating motion, accompanied by a loud } \\
\text { sound in some places. Intensity IV, coming from the east, duration of } 10 \\
\text { seconds. }\end{array}$ & - \\
\hline-73.3447 & 18.5028 & Anse-a-Veau & $\begin{array}{l}\text { (Scherer and Baltenweck, 1923): One very strong tremor, intensity V, } \\
\text { direction } \mathrm{N} \text {, duration } 15 \text { seconds. }\end{array}$ & - \\
\hline-72.8668 & 18.4315 & Petit Goave & $\begin{array}{l}\text { (Scherer and Baltenweck, 1923): One strong tremor, intensity V, duration } 7 \\
\text { seconds. }\end{array}$ & - \\
\hline-72.6978 & 19.1081 & St. Marc & (Bulletin, 1912): One very strong tremor, intensity IV, duration 5 seconds. & - \\
\hline-72.1040 & 18.8336 & Mirebalais & $\begin{array}{l}\text { (Scherer and Baltenweck, 1923): The oscillatory motions of the east to west } \\
\text { direction, duration } 10 \text { seconds, intensity IV. }\end{array}$ & - \\
\hline
\end{tabular}




\begin{tabular}{|l|l|l|l|}
\hline \multicolumn{2}{|l|}{ November 4, 1922} & Gonaives & $\begin{array}{l}\text { (Scherer and Baltenweck, 1922): One strong tremor, intensity IV to V, } \\
\text { duration 30 seconds, direction E. }\end{array}$ \\
\hline-72.6929 & 19.4458 & $\begin{array}{l}\text { (Scherer and Baltenweck, 1922): The tremor was generally noticed, intensity } \\
\text { IV. }\end{array}$ & $\begin{array}{l}\text { (Scherer and Baltenweck, 1922): One very strong tremor, duration 10 seconds; } \\
\text { intensity IV to V, the dogs were making a commotion. }\end{array}$ \\
\hline-72.0984 & 18.3755 & St. Michel & $\begin{array}{l}\text { (Scherer and Baltenweck, 1922): One tremor lasting 15 seconds, intensity IV, } \\
\text { direction S to N, it is said that the earthquake was preceded by another. }\end{array}$ \\
\hline-73.3745 & 19.8052 & Mole-St.Nicolas & $\begin{array}{l}\text { (Scherer and Baltenweck, 1922): Two tremors of 4 and 6 seconds of duration } \\
\text { felt by some of the inhabitants, some had left their houses, the bottles were } \\
\text { thrown down, the dogs were howling, intensity V. The direction seemed to } \\
\text { be vertical. }\end{array}$ \\
\hline-72.8370 & 19.9408 & Port-de-Paix & Pilate \\
\hline
\end{tabular}

\begin{tabular}{|c|c|c|c|c|}
\hline \multicolumn{5}{|c|}{ July 29, 1943} \\
\hline \multicolumn{5}{|c|}{$\begin{array}{l}\text { Time: 03:02:20.56 UTC earthquake origin time; July } 28,1943,11: 06: 00 \text { PM San Juan, Puerto Rico local time } \\
\text { Phenomenon Notes: }\left(-66.983^{\circ} \mathrm{W}, 19.090^{\circ} \mathrm{N}\right) \text { depth }=35 \mathrm{~km}, \mathrm{Mw}=7.6 \text { (Engdahl and Villaseñor, 2002). A small description of this earthquake came out in the } \\
\text { Seismological Notes section of the Bulletin of the Seismological Society of America (Ulrich, 1943). The Port-au-Prince observatory recored the iP wave at 03:03:38 } \\
\text { UTC. } \\
\text { Number of Observations: } 11\end{array}$} \\
\hline Longitude & Latitude & City & Description & \begin{tabular}{|l|} 
Intensity \\
\end{tabular} \\
\hline-66.6141 & 18.0115 & Ponce, Puerto Rico & $\begin{array}{l}\text { (McCann and others, } 2011 \text { quoting El Mundo, July } 30,1943) \text { : There were no } \\
\text { personal injuries or damages worth complaining about except for the } \\
\text { electric cables that snapped in various locations, especially on Molina } \\
\text { Street, in front of the police station. At the tearing of the cables, it caused a } \\
\text { small fire. }\end{array}$ & $\mathrm{CHF}(5)$ \\
\hline-67.1407 & 18.2009 & Mayaguez, Puerto Rico & $\begin{array}{l}\text { (McCann and others, } 2011 \text { quoting El Mundo July 30, 1943): At 11:00 PM two } \\
\text { strong earthquakes were felt that occurred almost seconds apart and each } \\
\text { lasted about one minute. These shakes repeated again at 1:00 in the } \\
\text { morning and then at 3:00 and at 4:00 in the morning but with less intensity. } \\
\text { According to information from the police, there were no damages or } \\
\text { personal injuries however the phones were interrupted. The habitants of } \\
\text { Mayaguez comment the curious event that the clock of the Presbyterian } \\
\text { church in the Marine stopped at 11:00 at night at the moment the first shock } \\
\text { was felt. }\end{array}$ & $\mathrm{CHF}(5)$ \\
\hline
\end{tabular}




\begin{tabular}{|c|c|c|c|c|}
\hline \multicolumn{5}{|c|}{ July 29, 1943} \\
\hline-69.8877 & 18.4722 & $\begin{array}{l}\text { Ciudad Trujillo } \\
\text { (Santo Domingo) }\end{array}$ & $\begin{array}{l}\text { (Miami Daily News, 1943): Fairly strong earth tremors rocked this city and } \\
\text { numerous inland centers late Wednesday night, but first reports indicated no } \\
\text { serious damage. }\end{array}$ & $\mathrm{CHF}(5)$ \\
\hline-66.1057 & 18.4665 & San Juan, Puerto Rico & $\begin{array}{l}\text { (McCann and others, } 2011 \text { quoting El Mundo, July 29, 1943): Last night at 11:06 } \\
\text { it was felt in San Juan and Santurce the first of two earthquakes that } \\
\text { according to calculations by the clock lasted close to a minute. } \\
\text { (McCann and others, } 2011 \text { quoting El Mundo, July 30, 1943): In P.R. the first } \\
\text { shock occurred at exactly 11:02 Wednesday night when the majority of the } \\
\text { population had retired for the night in their homes. Thousands of people } \\
\text { exited their homes at feeling the first tremor especially in the biggest cities } \\
\text { on the island where the majority of the buildings are made of concrete. } \\
\text { Fortunately, in the morning of yesterday, Thursday, there has been no } \\
\text { information from personal injuries or damage to property according to the } \\
\text { version dispatched by the police headquarters. We wait for final } \\
\text { information. } \\
\text { (Bodle, 1984): July 28, 23:02 [60th Meridian Time] Felt in San Juan by many. } \\
\text { Instrumental data indicated the shock centered near } 19.0^{\circ} \text { north, } 67.2^{\circ} \text { west, } \\
\text { about thirty-five miles off northwestern Puerto Rico. July } 29: 21: 04 \text { [60th } \\
\text { Meridian Time] San Juan Puerto Rico, Considerably less intense than the } \\
\text { shock on the 28th, but was sufficient intensity to stop the pendulum clock in } \\
\text { the Weather Bureau Office. It was felt by thousands of persons in Puerto } \\
\text { Rico. }\end{array}$ & $\mathrm{CHF}(4)$ \\
\hline-66.0720 & 18.4487 & Santurce, Puerto Rico & $\begin{array}{l}\text { (McCann and others, } 2011 \text { quoting El Mundo, July 29, 1943): At 11:09 the second } \\
\text { one was felt that was shorter of duration and was felt more in Santurce. }\end{array}$ & $\mathrm{CHF}(4)$ \\
\hline-66.1120 & 18.3579 & Guaynabo, Puerto Rico & $\begin{array}{l}\text { (McCann and others, } 2011 \text { quoting El Mundo, July 29, 1943): The seismic } \\
\text { motions were also felt in Guaynabo and in Ponce, according to information } \\
\text { we were able to receive last night. }\end{array}$ & $\mathrm{CHF}(4)$ \\
\hline-66.0347 & 18.2344 & Caguas, Puerto Rico & $\begin{array}{l}\text { (McCann and others, } 2011 \text { quoting El Mundo, July 30, 1943): There were no } \\
\text { reported damages or personal injuries. }\end{array}$ & $\mathrm{CHF}(3)$ \\
\hline-65.8265 & 18.1502 & Humacao, Puerto Rico & $\begin{array}{l}\text { (McCann and others, } 2011 \text { quoting El Mundo, July 30, 1943): Dr. Carlos Munoz } \\
\text { McCormick, director of Civil Defense informed us that they started to } \\
\text { receive information soon after the first earthquake was felt. From } \\
\text { Humacao, our correspondent informed us to following, "Of great intensity } \\
\text { was the earthquake from last night. It generated alarm especially with the }\end{array}$ & $\mathrm{CHF}(3)$ \\
\hline
\end{tabular}




\begin{tabular}{|c|c|c|c|c|}
\hline \multicolumn{5}{|c|}{ July 29, 1943} \\
\hline & & & public that were leaving the theater." & \\
\hline-72.3388 & 18.5432 & Port-au-Prince & $\begin{array}{l}\text { (Le Nouvelliste,1943): Last night at exactly } 10 \mathrm{~h} 5 \mathrm{~m} \text { 30s an earthquake was } \\
\text { felt in Port-au-Prince. Here are later observations from the Meteorological } \\
\text { Station of the Petit Seminary College St. Martial: Initial shock was in the } \\
\text { East direction, following vibrations transverse aligned North to South. The } \\
\text { earthquake lasted one minute and ten seconds, its intensity } 4 \text { to } 5 \text {. The } \\
\text { meteorological station of the Seminary thinks the serious shock occurred far } \\
\text { enough from the East. } \\
\text { (Bettembourg and others, 1950): [Instrument] iP 03:03:38 GMT, Felt at Port- } \\
\text { au-Prince, Intensity V-VI stopped clocks * * * July 28, 22:03:38 75th } \\
\text { Meridian Time, Port-au-Prince, Bainet, St. Marc, Cap Haitien, Intensity V, } \\
\text { duration } 5 \text { seconds, direction E-W. }\end{array}$ & $\mathrm{CHF}(4)$ \\
\hline- & - & $\begin{array}{l}\text { SJP, Magnetic Observatory, } \\
\text { San Juan, Puerto Rico } \\
\text { (Carl A. Ludy) }\end{array}$ & $\begin{array}{l}\text { (McCann and others, } 2011 \text { quoting El Mundo, July 30, 1943): There were } 19 \\
\text { earthquakes registered the night before last. They started at 11:02 PM and } \\
\text { ended at 7:45 AM. The epicenter was near the Mona Canal and recorded in } \\
\text { the U.S. The island was shaken } 19 \text { times by the earthquakes that were } \\
\text { registered starting at 11:00 PM the night of Wednesday until 8:00 in the } \\
\text { morning on Thursday according to information from the Magnetic } \\
\text { Observatory on the island. Mr. Carl A. Ludy, director of the observatory, } \\
\text { informed us yesterday that one of the stronger shocks occurred in the early } \\
\text { morning of Thursday and broke the seismometers in the observatory. } \\
\text { Director Ludy added that the epicenter of the earthquake evidently was near } \\
\text { the Mona Canal and it was most likely the earthquakes were recorded by } \\
\text { seismic stations on the continent. }\end{array}$ & - \\
\hline- & - & $\begin{array}{l}\text { Fordham University, New York } \\
\text { City, U.S. }\end{array}$ & $\begin{array}{l}\text { (McCann and others, } 2011 \text { quoting El Mundo, July 30, 1943): The news agency } \\
\text { Prensa Unida, informed us yesterday morning "that this was one of the } \\
\text { most severe earthquakes ever registered by the seismometer at Fordham } \\
\text { University in the last few years, occurring about 1,500 miles to the south of } \\
\text { New York, near the areas of Cuba or the Dominican Republic with the } \\
\text { possibility that substantial damages have occurred in the West Indies. The } \\
\text { first shock was registered at 11:07 PM and was followed by many other of } \\
\text { lesser intensity that evidently occurred near the same location". }\end{array}$ & - \\
\hline
\end{tabular}




\begin{tabular}{|l|l|l|l|}
\hline July 29, 1943 & & $\begin{array}{l}\text { seismologist reported today. He said the main shock came at 11:07.25 PM } \\
\text { eastern war time and was followed by 25 aftershocks in the next six hours. } \\
\text { All were about 1,655 miles from Boston, in a south by southeast direction. }\end{array}$ \\
\hline
\end{tabular}

\section{August 4, 1946}

Time: 17:51:12.68 UTC earthquake origin time; 12:52:00 PM Port-au-Prince local time, 75th meridian

Tsunami: According to Small (1948) a wave four to five meters high inundated communities along the northeastern coast of the Dominican Republic from

Matancitas to Cabrera. The largest aftershock on August 8, 1946 also generated a tsunami.

Landslides and other surface effects: According to an eyewitness report from the United Press, 1946c: The sea off northern Santo Domingo boiled like a pot of water on the stove and sent up a loud rumbling from the bottom as a result of Sunday's Caribbean earthquake. Capt. William C. Chishom of the Canadian motor ship Cameo said on his arrival here [San Juan, PR] today. The Dominican shore line, along which he was navigating when the quake struck, appeared to sink into the sea, sending a dust cloud half a mile in diameter 200 feet into the air. "It looked like a big shell had exploded on the shore," he said. "I was sitting in my cabin writing a letter when the ship suddenly began bucking. It threw me out of the chair. I thought we had run on a reef. I ran to the deck and noticed a cloud of dust, about the color of ginger, rising from the shore. It was about half a mile in diameter and rose about 200 feet in the air. The ship was trembling terribly and the sea was boiling like a pot of water on the stove. A loud rumbling came from the bottom of the ocean. I still thought we were on a reef and ordered all engines stopped. The boiling and rumbling lasted about two minutes and then all was quiet and the sea became calm. Thirty minutes later, at 2:40 PM, the ship began to tremble again but not as badly as at first, and the water boiled too. This lasted about 3 minutes and then it was all over." Location of the ship is not indicated in the article other than somewhere on the north shores of the Dominican Republic. There was also a report of a loud "submarine noise like an atomic bomb" heard before feeling the earthquake and the arrival of the tsunami at Matanzas, today called Matancitas (Miura, 1946).

Phenomenon Notes: $\left(-69.000^{\circ} \mathrm{W}, 18.959^{\circ} \mathrm{N}\right)$ depth $=\mathbf{5 1 . 2} \mathrm{km}, \mathrm{Mw}=\mathbf{7 . 9}, \mathrm{Ms}=\mathbf{8 . 0}, \mathrm{mb}=\mathbf{7 . 6}$ (Engdahl and Villaseñor, 2002). Lynch and Bodle (1948) wrote a detailed report on their descriptions of damages, with photographs, suffered in the Dominican Republic during their reconnaissance done in the middle of September 1946, published in the Bulletin of the Seismological Society of America. They also included an isoseismic intensity map for the Dominican Republic. Many seismometers, including those in San Juan, Guantanamo, Port-au-Prince, and New Orleans reported clipping while recording this earthquake. At the Port-au-Prince observatory, the iP wave was recorded at 17:51:59 UTC.

Number of Observations: 45

\begin{tabular}{|l|l|l|l|l|}
\hline Longitude & Latitude & City & Description \\
\hline-69.8255 & 19.3546 & $\begin{array}{l}\text { Matanzas } \\
\text { (Matancitas) }\end{array}$ & $\begin{array}{l}\text { (Miura, 1946): Persons reaching here from Matanzas said there were many } \\
\text { casualties. Four persons were reported dead. Broken communications } \\
\text { delayed a check on casualties and the toll may run much higher. Before the } \\
\text { earthquake, witnesses said, booming submarine explosions of great intensity } \\
\text { were heard. They compared them to descriptions of atom bomb explosions. } \\
\text { Then the quake hit. Buildings collapsed. Railroad tracks were twisted like } \\
\text { strands of steel wire. Roads were torn up. Villagers passing a sleepy Sunday } \\
\text { afternoon in the excessive heat jumped up and ran for open country. Next } \\
\text { came the tidal wave. With a swelling roar it rolled up the bay and smashed } \\
\text { against the towns. Dwellings and shops were swept away by the waves. } \\
\text { Slabs of walls and roofs were hurled inland from the shore. (A U.S. Navy } \\
\text { pilot from Puerto Rico who flew over Matanzas said the tidal wave seemed } \\
\text { to have destroyed most of the town). After the tidal wave, reports said there }\end{array}$ \\
\end{tabular}




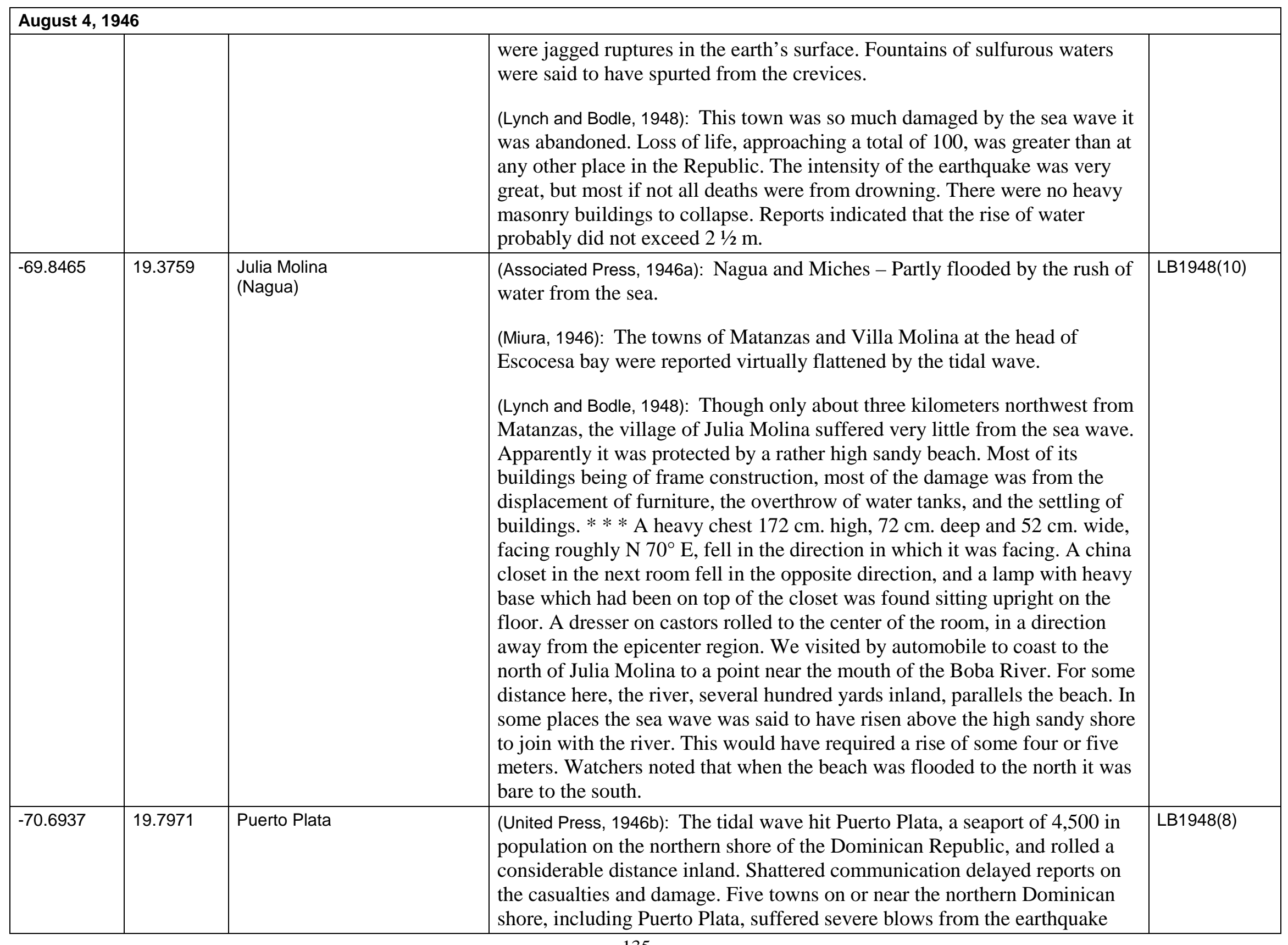




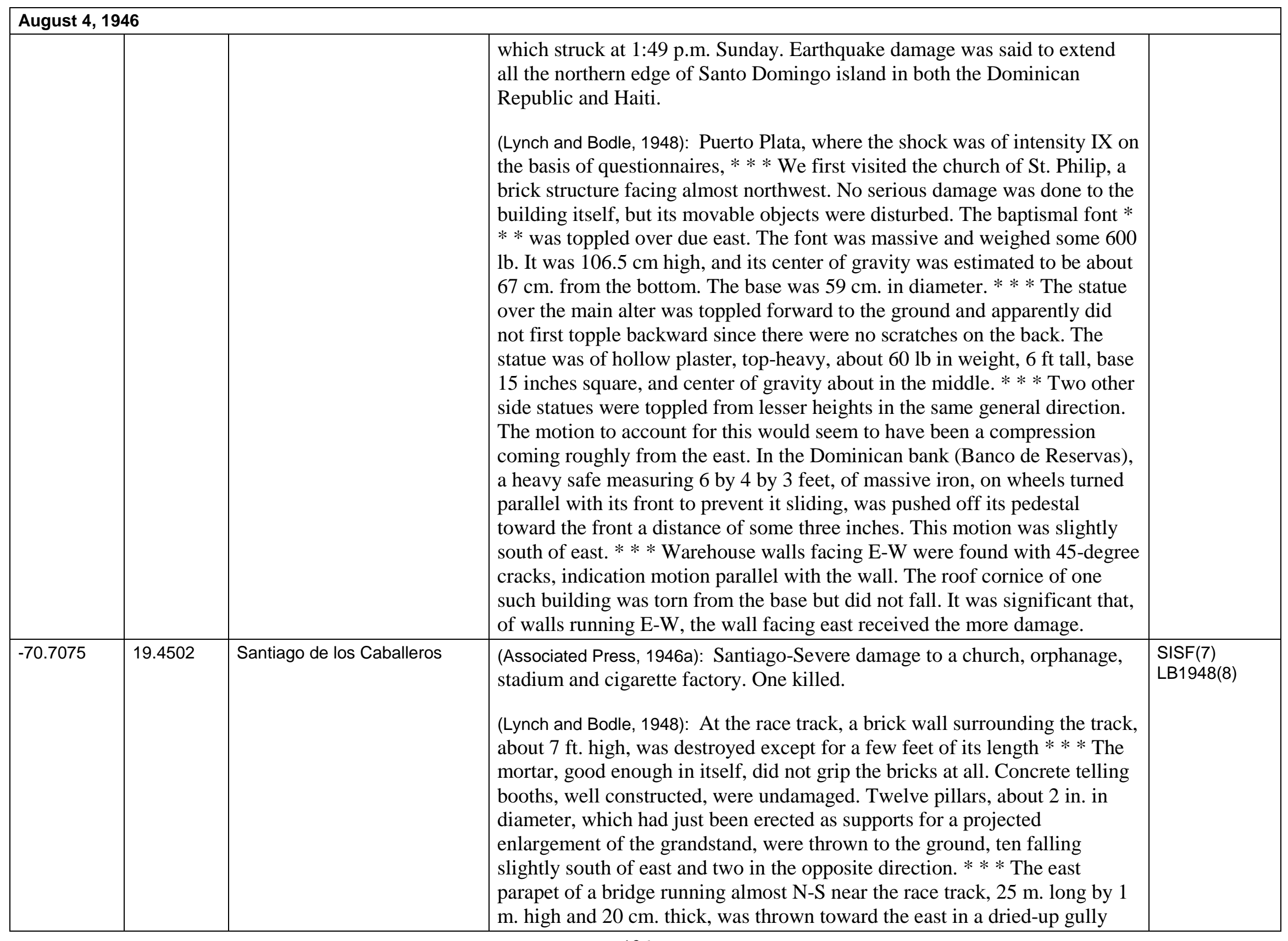




\begin{tabular}{|c|c|c|c|c|}
\hline \multicolumn{5}{|c|}{ August 4, 1946} \\
\hline & & & $\begin{array}{l}\text { great in San Francisco de Macoris and other cities a few miles inland. } \\
\text { (Lynch and Bodle, 1948): It was evident as we drove into the town that it had } \\
\text { suffered much more damage than its immediate neighbors. The reason } \\
\text { became clear as we walked down to the near-by encircling stream. The bed } \\
\text { of the shallow stream was of solid rock, and the town was built on a silt } \\
\text { plateau perhaps one hundred feet higher. One death occurred here from the } \\
\text { collapse of a house. Many buildings were severely damaged, including a } \\
\text { large church which was being torn down when we arrived. Its roof had } \\
\text { fallen in and the side walls were badly cracked. The circular portion and } \\
\text { dome over the altar, however, were fairly intact. *** A short distance away } \\
\text { were ruins of a frame house with a front part of brick. The brick part was so } \\
\text { severely damaged that it had to be torn down. This left the staircase and } \\
\text { living room exposed to the street. }\end{array}$ & LB1948(10) \\
\hline-70.0295 & 19.2089 & Castilla & $\begin{array}{l}\text { (Lynch and Bodle, 1948): Brick walls around yards of residences were } \\
\text { toppled; one running in an E-W direction fell to both north and south, and } \\
\text { one running N-S fell to east and west. Another N-S wall some } 15 \text { to } 20 \text { feet } \\
\text { long by } 10 \text { inches thick fell to the west. Damage was also caused at a } \\
\text { cemetery near the edge of the town. A wall some } 3 \text { feet high and about } 19 \\
\text { m. in length along its north side was almost entirely thrown down. Some } \\
\text { parts fell north, others south. Just inside the north gate, damage was done to } \\
\text { a brick burial vault. The corner in triangular section on the sides, with apex } \\
\text { just below the roof, fell away. At the south gate a heavy cross fell } \\
\text { approximately } \mathrm{N} 60^{\circ} \mathrm{W} \text {. }\end{array}$ & - \\
\hline-69.3390 & 19.2061 & Samana & $\begin{array}{l}\text { (Lynch and Bodle, 1948): No damaging effects of sea waves were seen by us } \\
\text { here or at any other point on Samana Bay though some abnormal ebb-and- } \\
\text { flow effects were noted. Buildings near the beach were damaged little short } \\
\text { of severely. As the party moved back to higher ground, less severe effects } \\
\text { were seen. Inspection of a recently completed hospital of concrete showed } \\
\text { no damage of consequence, probably because its construction was good and } \\
\text { its site more satisfactory. A brick wall around the hospital grounds was } \\
\text { damaged by cracks, indicating that there had been considerable motion. }\end{array}$ & $\begin{array}{l}\text { SISF(7.5) } \\
\text { LB1948(9) }\end{array}$ \\
\hline
\end{tabular}




\begin{tabular}{|c|c|c|c|c|}
\hline \multicolumn{5}{|c|}{ August 4, 1946} \\
\hline & & & noted, but no high water of consequence was observed. & \\
\hline-69.6131 & 19.2279 & Sanchez & $\begin{array}{l}\text { (Lynch and Bodle, 1948): At Sanchez the damage of most interest occurred at } \\
\text { the pier. The railroad tracks were warped where the pier made contact with } \\
\text { the shore. (see fig. 14) At the offshore end, four large concrete columns } \\
\text { were either broken or tilted. They were made of concrete poured into } \\
\text { tubular steel forms rising some } 15 \text { feet above the pier deck. Two were at the } \\
\text { offshore corners of the pier, and the other two at some distance out in the } \\
\text { water, * * Both columns at the end of the pier were broken off a short } \\
\text { distance above deck level, where the size of the tubular steel forms had been } \\
\text { reduced by some } 4 \text { to } 5 \text { inches in radius. (see fig. 15) Both of these columns } \\
\text { fell in an easterly direction. Although the outer pair did not break, they were } \\
\text { left tilting toward the south. }\end{array}$ & LB1948(9) \\
\hline-69.8605 & 19.1876 & Arenoso & $\begin{array}{l}\text { (Lynch and Bodle, 1948): At Arenoso, several houses perched at the edge of } \\
\text { the river bank had been damaged by the slumping effects. }\end{array}$ & - \\
\hline-69.9112 & 19.1823 & Villa Rivas & $\begin{array}{l}\text { (Lynch and Bodle, 1948): } * * * \text { the local church had been destroyed on August } \\
\text { 4. Perhaps the direction in which the steeple fell was controlled to an } \\
\text { appreciable degree by the orientation of the structure. The long dimension } \\
\text { was nearly coincident with the direction of the epicenter. The front of the } \\
\text { church faced approximately } \mathrm{S} 55^{\circ} \mathrm{W} \text {. The local pastor } * * * \text { reported that } \\
\text { the steeple rocked to and fro some three times before falling into the body } \\
\text { of the church. As it fell, the north and south walls of brick were forced } \\
\text { outward. People who were passing reported that the steeple swayed out over } \\
\text { the street before going down. The spire was some } 53 \mathrm{ft} \text {. above ground. Side } \\
\text { walls of the main building were } 22 \mathrm{ft} \text {. high. It was interesting to note that } \\
\text { some of the rear wall fell into the interior of the church but that most of it } \\
\text { remained standing. A few hundred yards away a heavy store safe fell } \\
\text { approximately } \mathrm{N} 65^{\circ} \mathrm{W} \text {. }\end{array}$ & - \\
\hline-72.3388 & 18.5432 & Port-au-Prince & $\begin{array}{l}\text { (United Press, 1946a): The shocks were felt in Port au Prince, Haiti at the } \\
\text { western end of Santo Domingo. } \\
\text { (Bettembourg and others, 1950): August 4, iP - 17:51:59 GMT, Felt all over } \\
\text { the island, Intensity VII - VIII. Undulatory motion, duration more than a } \\
\text { minute. } \\
\text { (Bettembourg, 1950): Hour: } 12 \text { h } 52 \mathrm{~m} 05 \text { s (75th meridian time) Twelve } \\
\text { seconds after it started, the instrument of the Observatory of the Seminary }\end{array}$ & - \\
\hline
\end{tabular}




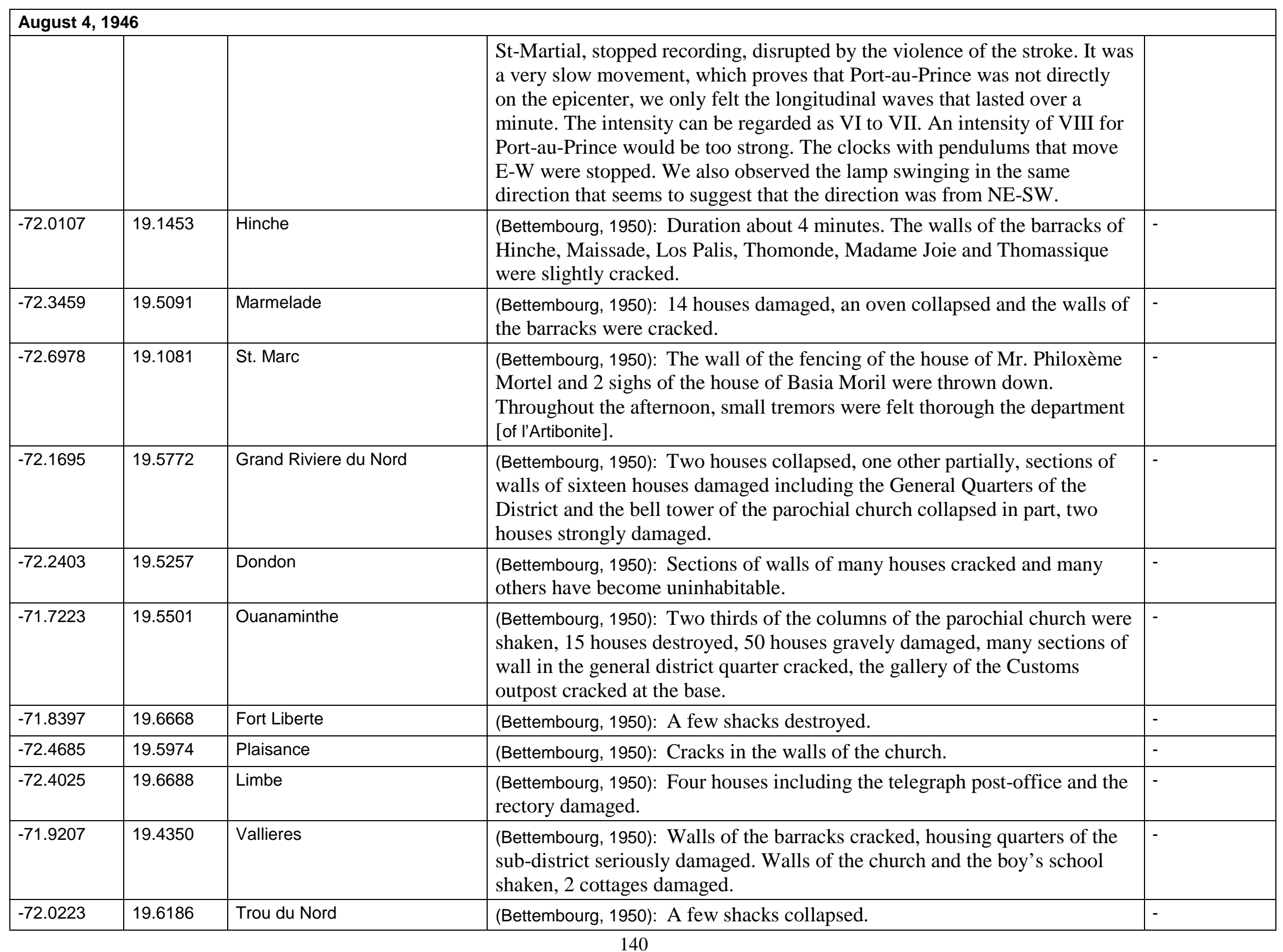




\begin{tabular}{|c|c|c|c|c|}
\hline \multicolumn{5}{|c|}{ August 4, 1946} \\
\hline-69.8877 & 18.4722 & $\begin{array}{l}\text { Ciudad Trujillo } \\
\text { (Santo Domingo) }\end{array}$ & $\begin{array}{l}\text { (Associated Press, 1946a): This capital was only slightly damaged } * * * \text { The } \\
\text { Ciudad Trujillo docks suffered slight cracks and some ancient churches also } \\
\text { were damaged. } \\
\text { (Lynch \& Bodle, 1948): } * * * \text { little damage was done except to some old } \\
\text { buildings including some minor damage to the cathedral in which the } \\
\text { remains of Columbus rest. [Description of damage to a bridge near Santo } \\
\text { Domingo.] The bridge was built by the United States Steel Export Company } \\
\text { of New York. The picture (fig. 1), taken about 9:30 A.M., shows the bridge } \\
\text { running roughly N-S. The factory to the right, with the tall chimneys, is a } \\
\text { newly completed cement factory, and suffered no damage. The bridge had } \\
\text { been subjected to a distinct E-W motion and suffered a lateral displacement } \\
\text { at each end toward the east. [Describing the series of photographs in the article.] } \\
\text { The north ends moved a good inch more than the south ends. There was } \\
\text { evidence of a to-and-fro motion with a resulting permanent displacement } \\
\text { toward the east. This displacement amounted to } 25 / 8 \text { inches at the north } \\
\text { end and } 11 / 4 \text { inches at the south end. }\end{array}$ & LB1948(6) \\
\hline-71.6507 & 19.8474 & Monte Cristi & $\begin{array}{l}\text { (Lynch and Bodle, 1948): Intensity V based on isoseismic map in Lynch and Bodle, } \\
1948 .\end{array}$ & LB1948(5) \\
\hline-69.3112 & 18.4526 & San Pedro de Macoris & $\begin{array}{l}\text { (Lynch and Bodle, 1948): Intensity VI based on isoseismic map in Lynch and Bodle, } \\
1948 .\end{array}$ & LB1948(6) \\
\hline-69.0364 & 18.7648 & Seibo & $\begin{array}{l}\text { (O'Loughlin and Lander, 2003): Much damage from the earthquake was also } \\
\text { reported at Cabrera, San Francisco de Macoris, and Castilla, all Intensity } \cong \\
\text { X; Puerto Plata, Moca and Cabo Cabron, all Intensity } \cong \text { IX; El Seibo, } \\
\text { Santiago, Ciudad Trujillo, San Pedro de Macoris, La Romana and many } \\
\text { other places. }\end{array}$ & - \\
\hline-69.2602 & 19.3204 & Cabo Cabron & $\begin{array}{l}\text { (O'Loughlin and Lander, 2003): Much damage from the earthquake was also } \\
\text { reported at Cabrera, San Francisco de Macoris, and Castilla, all Intensity } \cong \\
\text { X; Puerto Plata, Moca and Cabo Cabron, all Intensity } \cong \text { IX; El Seibo, } \\
\text { Santiago, Ciudad Trujillo, San Pedro de Macoris, La Romana and many } \\
\text { other places. }\end{array}$ & - \\
\hline
\end{tabular}




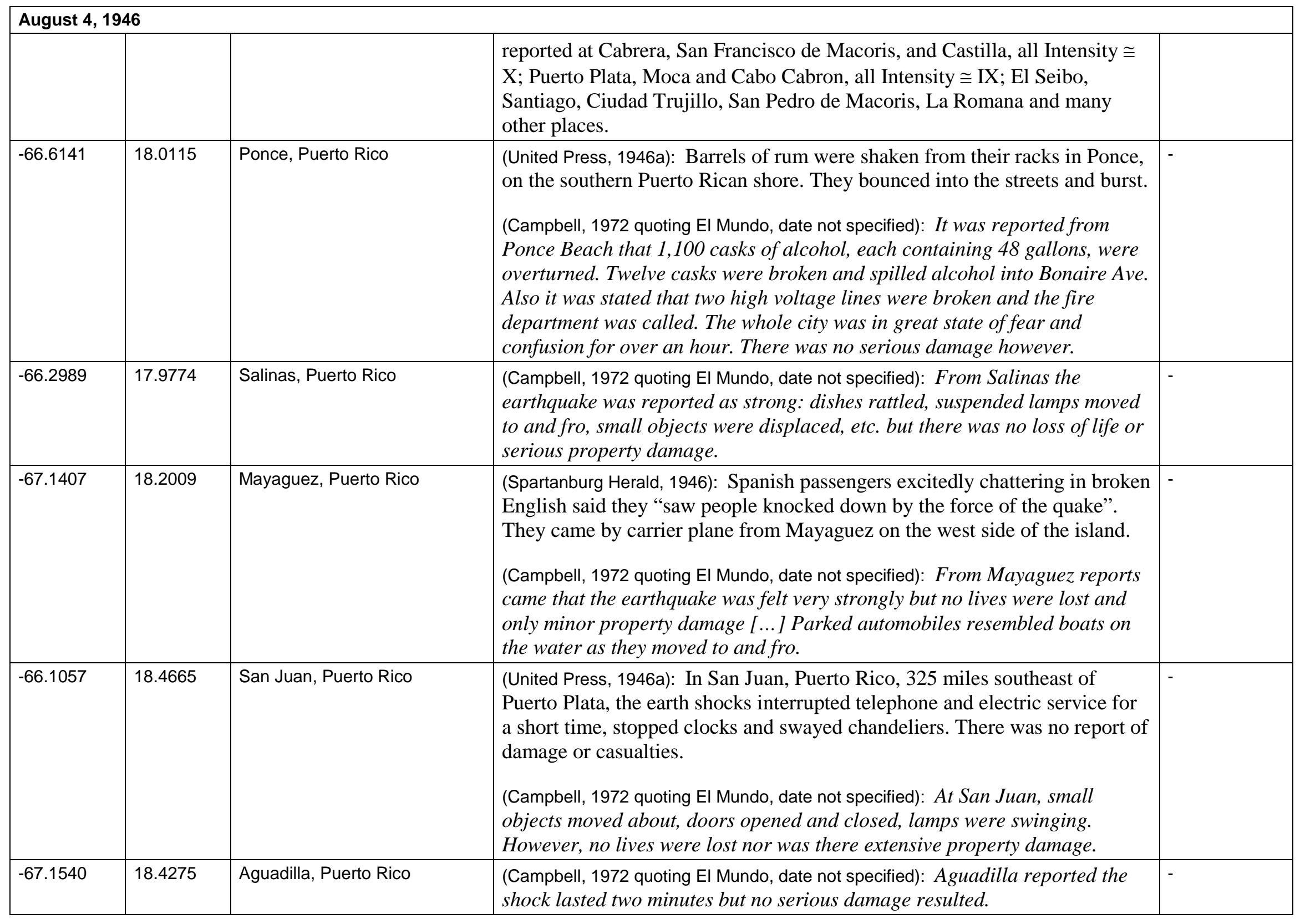




\begin{tabular}{|c|c|c|c|c|}
\hline August 4 & & & & \\
\hline-67.1414 & 18.2885 & Añasco, Puerto Rico & $\begin{array}{l}\text { (Campbell, } 1972 \text { quoting El Mundo, date not specified): At Añasco, the school } \\
\text { was slightly damaged and classes were suspended. }\end{array}$ & - \\
\hline-66.9911 & 18.3383 & San Sebastian, Puerto Rico & $\begin{array}{l}\text { (Campbell, } 1972 \text { quoting El Mundo, date not specified): At San Sebastian, the } \\
\text { Catholic church was badly damaged and clocks stopped at 13:56. Churches } \\
\text { were not in session. }\end{array}$ & \\
\hline-66.9799 & 18.1808 & Maricao, Puerto Rico & (Campbell, 1972): IV at Comerio Plants, Maricao, and Mona Island. & - \\
\hline-67.8923 & 18.0860 & Mona Island, Puerto Rico & (Campbell, 1972): IV at Comerio Plants, Maricao, and Mona Island. & - \\
\hline-64.9309 & 18.3420 & $\begin{array}{l}\text { Charlotte Amalie, } \\
\text { St. Thomas, Virgin Islands }\end{array}$ & $\begin{array}{l}\text { (Associated Press, 1946b): The Virgin Islands had only a mild shock and no } \\
\text { damage reported. } \\
\text { (Daily News, 1946): The earthquake which racked the Virgin Islands on } \\
\text { Sunday afternoon at } 2 \text { o'clock is described as being more severe than the } \\
\text { one which leveled San Francisco in 1906. Although only the tail-end of it } \\
\text { was felt here the full force is reported to have done terrific damage to } \\
\text { northern towns of Santo Domingo. }\end{array}$ & - \\
\hline
\end{tabular}

\section{October 28, 1952}

Time: 04:25:56.4 UTC earthquake origin time; Oct. 27, 1952, at 23:29:51 local time, 75th meridian Port-au-Prince

Phenomenon Notes: $\left(-73.520^{\circ} \mathrm{W}, \mathbf{1 8 . 5 1 0 ^ { \circ }} \mathrm{N}\right)$ depth $=\mathbf{2 4} \mathbf{~ k m}, \mathbf{M s}=5.9$ (Sykes and Ewing, 1965). The observatory at Seminare-College St-Martial conducted a geologic reconnaissance of this earthquake in the Asile valley south of Anse-a-Veau. The Haitian government invited the United States Coast and Geodetic Survey (USCGS) Chief Seismologist Frank Neumann to provide his professional opinion and assessment of earthquake risk in Haiti. The Port-au-Prince bulletin for 1952 generated and published a report that included a geology map of the region most affected by this earthquake and an intensity map where some of the lower intensities are included in this list. The seismometer at the observatory recorded the P wave arrival at 23:30:16 local time, 04:30:16 UTC (Bettembourg and others, 1955).

Number of Observations: 29

\begin{tabular}{|l|l|l|l|}
\hline Longitude & Latitude & City & Description \\
\hline-73.3447 & 18.5028 & Anse-a-Veau & $\begin{array}{l}\text { (Bettembourg and others, 1955): Two tremors at a low interval, accompanied } \\
\text { by a low rumble coming from the South-East. Movement vertical and } \\
\text { swaying from two perpendicular directions North-South, East-West. } \\
\text { Damages in the church: cracks on the facade and various locations inside, } \\
\text { one display, placed above the altar and supported by marble columns a } \\
\text { meter high, lies crushed at the foot of the altar. It fell in the NW direction. } *\end{array}$ \\
\hline
\end{tabular}




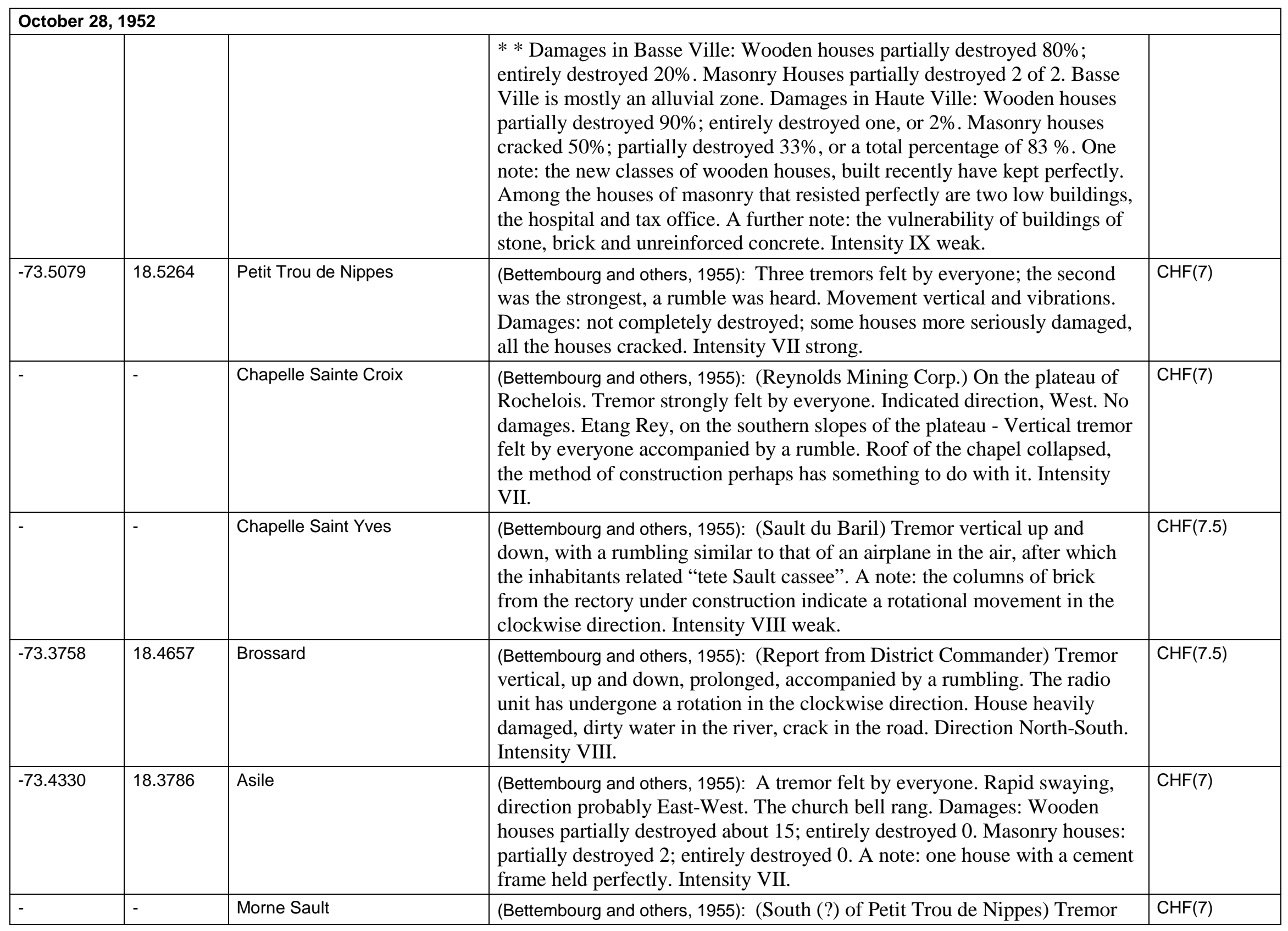




\begin{tabular}{|c|c|c|c|c|}
\hline \multicolumn{5}{|c|}{ October 28, 1952} \\
\hline & & & $\begin{array}{l}\text { vertical, up and down, felt by everyone. Cracks in the soil, landslides. } \\
\text { Damages reported by various chapels. Intensity VIII. }\end{array}$ & \\
\hline-72.6334 & 18.5111 & Leogane & $\begin{array}{l}\text { (Bettembourg and others, 1955): Tremor felt by almost everyone. Rapid } \\
\text { swinging East - West. Cracking noises from houses, no damages. Intensity } \\
\text { V. }\end{array}$ & $\mathrm{CHF}(4)$ \\
\hline-72.7709 & 18.4256 & Grand Goave & $\begin{array}{l}\text { (Bettembourg and others, 1955): Tremor felt by all the inhabitants. Rapid } \\
\text { swinging East - West. Church clock stopped. Minor damages, however it } \\
\text { was noted: the collapse of a wall of the chapel of Saint Antoine. Intensity: } \\
\text { VI strong. }\end{array}$ & $\mathrm{CHF}(5)$ \\
\hline-72.8668 & 18.4315 & Petit Goave & $\begin{array}{l}\text { (Bettembourg and others, 1955): Tremor felt by all the inhabitants. A low } \\
\text { rumble was heard. Vibrations North-South and swaying. Stopped the clock. } \\
\text { Insignificant damages. Intensity VI strong. }\end{array}$ & $\mathrm{CHF}(5)$ \\
\hline-73.0861 & 18.4423 & Miragoave & $\begin{array}{l}\text { (Bettembourg and others, 1955): Two tremors at a low interval. Rapid } \\
\text { swinging North-South. Cracking noises in houses, several small cracks. } \\
\text { Intensity VI. }\end{array}$ & $\mathrm{CHF}(6)$ \\
\hline-73.6387 & 18.4829 & Baraderes & $\begin{array}{l}\text { (Bettembourg and others, 1955): One tremor felt by everyone. Direction } \\
\text { North-South. Swinging in all directions. No damages. Intensity V weak. }\end{array}$ & $\mathrm{CHF}(4.5)$ \\
\hline-74.1145 & 18.6446 & Jeremie & $\begin{array}{l}\text { (Bettembourg and others, 1955): Two tremors at three second intervals; the } \\
\text { second was very strong. Slow swinging. Direction East-West. No damages. } \\
\text { Intensity IV. }\end{array}$ & $\mathrm{CHF}(4)$ \\
\hline-72.3388 & 18.5432 & Port-au-Prince & $\begin{array}{l}\text { (Bettembourg and others, 1955): At the seismograph the primary waves are } \\
\text { clearly marked at 23h. 30m. 16s. The initial displacement of the needles on } \\
\text { the E-W component is towards the North; the needles on the N-S } \\
\text { component are towards the South, the earthquake came from the West. The } \\
\text { oscillations quickly amplified and } 20 \text { seconds after the first traces were } \\
\text { registered, the moving needles stopped recording and at the same time the } \\
\text { clock stopped. From the report by a reader of the "Match" at this late hour, } \\
\text { the movement was somehow announced by the howls of his dog and of all }\end{array}$ & $\mathrm{CHF}(4)$ \\
\hline
\end{tabular}




\begin{tabular}{|c|c|c|c|c|}
\hline \multicolumn{5}{|c|}{ October 28, 1952} \\
\hline & & & $\begin{array}{l}\text { those in the neighborhood. He felt a sudden jolt, followed by a horizontal } \\
\text { rocking from West to East, with a duration of twelve seconds. It all ended } \\
\text { with a vertical jolt, by another source of information, they awakened by the } \\
\text { first shock, confirmed. }\end{array}$ & \\
\hline-73.3971 & 18.2816 & Aquin & (Bettembourg and others, 1955): From earthquake intensity map in report: V. & $\mathrm{CHF}(5)$ \\
\hline-73.7500 & 18.1945 & Les Cayes & (Bettembourg and others, 1955): From earthquake intensity map in report: IV. & $\mathrm{CHF}(4)$ \\
\hline-73.8890 & 18.5671 & Corail & (Bettembourg and others, 1955): From earthquake intensity map in report: IV. & $\mathrm{CHF}(4)$ \\
\hline-74.3959 & 18.3242 & Tiburon & (Bettembourg and others, 1955): From earthquake intensity map in report: III. & $\mathrm{CHF}(3)$ \\
\hline-74.4222 & 18.5605 & Dame-Marie & (Bettembourg and others, 1955): From earthquake intensity map in report: III. & $\mathrm{CHF}(3)$ \\
\hline-72.0683 & 18.2370 & Saltrou & (Bettembourg and others, 1955): From earthquake intensity map in report: III. & $\mathrm{CHF}(3)$ \\
\hline-72.5126 & 18.7701 & Arcahaie & (Bettembourg and others, 1955): From earthquake intensity map in report: III. & $\mathrm{CHF}(3)$ \\
\hline-72.1040 & 18.8336 & Mirebalais & (Bettembourg and others, 1955): From earthquake intensity map in report: III. & $\mathrm{CHF}(3)$ \\
\hline-72.8673 & 18.8365 & Anse-a-Galets & (Bettembourg and others, 1955): From earthquake intensity map in report: IV. & $\mathrm{CHF}(4)$ \\
\hline-72.6978 & 19.1081 & St. Marc & (Bettembourg and others, 1955): From earthquake intensity map in report: III. & $\mathrm{CHF}(3)$ \\
\hline-72.6929 & 19.4458 & Gonaives & (Bettembourg and others, 1955): From earthquake intensity map in report: III. & $\mathrm{CHF}(3)$ \\
\hline- & - & $\begin{array}{l}\text { Ciudad Trujillo } \\
\text { (Santo Domingo) }\end{array}$ & $\begin{array}{l}\text { (Bettembourg and others, 1955): From the information by courtesy of Dr. } \\
\text { Franco y Franco, Ambassador of the Dominican Republic, to whom we are } \\
\text { pleased to express our gratitude, the devices in Ciudad Trujillo recorded for } \\
\text { one hour. The distance is estimated to be } 445 \mathrm{~km} \text {. Arrival time of the } \\
\text { phases: (Local Time } 75 \text { th Mer.) P: } 23 \mathrm{~h} 30 \mathrm{~m} \mathrm{54s,} \mathrm{S:} 23 \mathrm{~h} 31 \mathrm{~m} 36 \mathrm{~s} \text {; } \\
\text { (Greenwich Time on Oct. 28) P: } 04 \mathrm{~h} 30 \mathrm{~m} 54 \mathrm{~s} \text {, S: } 04 \mathrm{~h} 21 \mathrm{~m} 36 \mathrm{~s} \text {. }\end{array}$ & - \\
\hline- & - & $\mathrm{BCIS}$ & $\begin{array}{l}\text { (Bettembourg and others, 1955): The Bulletin of the Bureau Central } \\
\text { International de Seismologie de Strasbourg (B.C.I.S.) the hour of the } \\
\text { earthquake source is fixed for October 28, 1952, H = 04h } 29 \mathrm{~m} \mathrm{52s,} \\
\text { Geographic Coordinates } 18.3 \text { deg N and } 73.3 \mathrm{deg} \text { W. }\end{array}$ & - \\
\hline- & - & USCGS & $\begin{array}{l}\text { (Bettembourg and others, 1955): The United States Coast and Geodetic Survey } \\
\text { (U.S.C.G.S.) gives } \mathrm{H}=04 \mathrm{~h} 29 \mathrm{~m} 51 \mathrm{~s} \text { at } 18 \mathrm{deg} 30 \mathrm{~min} \mathrm{~N} \text { and } 73 \text { deg } 30 \mathrm{~min} \\
\text { W. }\end{array}$ & - \\
\hline
\end{tabular}

\section{January 25, 1953}

Time: 19:47:57.4 UTC earthquake origin time; 02:50:00 PM Anse-a-Veau local time 75th meridian

Phenomenon Notes: $\left(-73.420^{\circ} \mathrm{W}, 18.470^{\circ} \mathrm{N}\right)$ depth $=0 \mathrm{~km}, \mathrm{Ms}=5.7$ (Sykes and Ewing, 1965). Aftershock of October 28, 1952. The seismometer at the Port-auPrince observatory recored the iP wave at 19:48:14 UTC (Bettembourg, Scneider and Schumacher, 1956).

Number of Observations: 5

Longitude $\quad$ Latitude 


\begin{tabular}{|c|c|c|c|c|}
\hline \multicolumn{5}{|c|}{ January 25, 1953} \\
\hline-73.3447 & 18.5028 & Anse-a-Veau & $\begin{array}{l}\text { (Le Nouvelliste,1953a): The tremor registered yesterday about three o'clock in } \\
\text { the afternoon at Port-au-Prince was also felt in other parts of the territory of } \\
\text { the Republic in particular Petit-Riviere de Nippes, Anse-a-Veau and towns } \\
\text { in the south point of the country. The courageous people of Anse-a-Veau } \\
\text { were again hit hardest yesterday. Two houses in the lower town collapsed } \\
\text { causing the deaths of two villagers *** Several other houses were also } \\
\text { damaged. Water pipes broke in town that had been particularly hit by the } \\
\text { earthquake yesterday afternoon. The first witnesses met this morning at the } \\
\text { capitol to inform this last earthquake of high intensity was felt. At } 2 \mathrm{H} 50 \mathrm{M} \\
\text { in Anse-a-Veau, and it lasted about five seconds. } \\
\text { (Bettembourg and others, 1956): Following the earthquake of October } 27 \text {, } \\
\text { 1952, small tremors were frequently felt by the residents of Anse-a-Veau, } \\
\text { until the end of March 1953. The earthquake of January 25, 1953, was very } \\
\text { strong in Port-a-Prince and in many localities in the Republic, seems to have } \\
\text { been preceded by a night of January } 24 \text { to } 25 \text {. Later information provided by } \\
\text { the General Headquarters of the Army of Haiti, the intensity seems to have } \\
\text { been the strongest on the side of Sault du Baril. }\end{array}$ & $\begin{array}{l}\mathrm{CHF}(5) \\
\operatorname{SISF}(7)\end{array}$ \\
\hline-73.2446 & 18.4770 & Petite Riviere de Nippes & $\begin{array}{l}\text { (Le Nouvelliste,1953a): The tremor registered yesterday about three o'clock in } \\
\text { the afternoon at Port-au-Prince was also felt in other parts of the territory of } \\
\text { the Republic in particular Petit-Riviere de Nippes, Anse-a-Veau and towns } \\
\text { in the south point of the country. }\end{array}$ & $\mathrm{CHF}(4)$ \\
\hline-72.3388 & 18.5432 & Port-au-Prince & $\begin{array}{l}\text { (Bettembourg and others, 1956): Felt in Port-au-Prince, stopped the clock, Pi: } \\
\text { 19H 48M 14S GMT. }\end{array}$ & $\mathrm{CHF}(3)$ \\
\hline-73.7500 & 18.1945 & Les Cayes & (Bettembourg and others, 1956): Felt. & $\mathrm{CHF}(3)$ \\
\hline-72.7558 & 18.1819 & Bainet & (Bettembourg and others, 1956): Felt. & $\mathrm{CHF}(3)$ \\
\hline
\end{tabular}

\section{February 26, 1953}

Time: 16:09:24.7 UTC earthquake origin time; 10:11:00 AM local time 75th meridian

Phenomenon Notes: $\left(-73.310^{\circ} \mathrm{W}, 18.500^{\circ} \mathrm{N}\right)$ depth=0, Ms=4.9 (Sykes and Ewing, 1965). Aftershock attributed to the October 28,1952 , earthquake. The seismometer at the Port-au-Prince observatory was down for repairs and did not record this earthquake. (Bettembourg and others, 1956).

Number of Observations: 2

\begin{tabular}{|l|l|l|l|l|}
\hline Longitude & Latitude & City & Description & Intensity \\
\hline-73.3447 & 18.5028 & Anse-a-Veau & $\begin{array}{l}\text { (Le Nouvelliste,1953b): A strong tremor was felt yesterday in Anse-a-Veau } \\
\text { about two o'clock in the afternoon. This earthquake caused damages with } \\
\text { the collapse of the columns of the parish church. A few of our remaining }\end{array}$ \\
\hline
\end{tabular}




\begin{tabular}{|l|l|l|l|}
\hline \multicolumn{2}{|l|}{ February 26, 1953 } & & $\begin{array}{l}\text { buildings in the city were also damaged. } \\
\text { (Bettembourg and others, 1956): Intensity III - IV. }\end{array}$ \\
\hline-72.3388 & 18.5432 & Port-au-Prince & $\begin{array}{l}\text { (Bettembourg and others, 1956): Felt in Port-au-Prince. On February 26, new } \\
\text { tremor around 10H 11M. The instrument, because of repairs, was not } \\
\text { functioning on that day. Felt in Port-au-Prince with an intensity III, it seems } \\
\text { to have been stronger at Anse-a-Veau. Since then the balance seems to have } \\
\text { been restored because, it no longer reports or rarely very small tremors. }\end{array}$ \\
\hline
\end{tabular}




\section{Other Significant Earthquakes of the Caribbean:}

\section{Puerto Rico and Virgin Islands}

Intensity, Mercalli Magnitude Intensities (3-10); CHF, assigned by C. H. Flores (author); WHB, assigned by W. H. Bakun (co-author); SISF, assigned by SisFrance/Antilles (2010); R1964, assigned by Robson (1964); - no intensity assigned.

\begin{tabular}{|c|c|c|c|c|}
\hline \multicolumn{5}{|c|}{ July 11,1785} \\
\hline \multicolumn{5}{|c|}{$\begin{array}{l}\text { Time: 3:00 AM, Tortola local time } \\
\text { Phenomenon Notes: None } \\
\text { Number of Observations: } 7 \\
\end{array}$} \\
\hline Longitude & Latitude & City & Description & Intensity \\
\hline-64.6223 & 18.4290 & Tortola, British Virgin Islands & $\begin{array}{l}\text { (McCann and others, 2011, quoting The Times of London, Sept. 8, 1785): By Capt. } \\
\text { Black of the Mary, from Tortola, we are informed that between two and } \\
\text { three o'clock in the morning of Monday, the 11th of July, there was a violent } \\
\text { and tremendous shock of an earthquake in Tortola, which continued near } \\
\text { half a minute. It was felt with more or less violence in all adjacent islands } \\
\text { but with little damage* * *The subterraneous noise was like rolling a great } \\
\text { number of casks in a large loft. The report ashore was it lasted above a } \\
\text { minute, several fractures of rocks were precipitated from the mountains, } \\
\text { and several houses damaged, but at Spanish-Town the report was, that a } \\
\text { large part of the island severed, and several large fractures of rocks whirled } \\
\text { to a considerable distance. There was an uncommon agitation of the sea } \\
\text { caused by it, but a strong smell of sulfur in some places immediately } \\
\text { followed. } \\
\text { (Mallet and Mallet, 1858): In Tortola the earthquake made great clefts in the } \\
\text { rocks, and separated completely a part of the island, forming a new island. } \\
\text { (Perrey, 1847): at Tortola and by ships out at sea. } \\
\text { (Shaler, 1869): The island of Tortola, which was swept over during this } \\
\text { convulsion by an earthquake wave, was rent asunder by the earthquake of } \\
\text { 1785, a new island being formed. Our accounts of this remarkable event are } \\
\text { not sufficiently detailed to enable us to form an idea of the precise character } \\
\text { of the movement which brought the separation about. }\end{array}$ & $\begin{array}{l}\text { CHF(5) } \\
\text { WHB } \\
\text { SISF(6) } \\
\text { R1964(8) }\end{array}$ \\
\hline-64.4341 & 18.4496 & Spanish Town, Virgin Gorda & $\begin{array}{l}\text { (McCann and others, 2011, quoting The Times of London, Sept. } 8,1785): * * * \\
\text { but at Spanish-Town the report was, that a large part of the island severed, } \\
\text { and several large fractures of rocks whirled to a considerable distance. }\end{array}$ & $\mathrm{CHF}(6.5)$ \\
\hline
\end{tabular}




\begin{tabular}{|c|c|c|c|c|}
\hline \multicolumn{5}{|c|}{ July 11,1785} \\
\hline & & & $\begin{array}{l}\text { There was an uncommon agitation of the sea caused by it, but a strong } \\
\text { smell of sulfur in some places immediately followed. }\end{array}$ & \\
\hline-62.7494 & 17.3174 & $\begin{array}{l}\text { St. Christopher } \\
\text { (St. Kitts) }\end{array}$ & $\begin{array}{l}\text { (McCann and others, 2011, quoting The Times of London, Sept. 15, 1785): It was } \\
\text { felt experienced by all the neighboring islands much about the same time, } \\
\text { and several vessels a number of leagues out at sea felt it, especially a small } \\
\text { one at St. Kitt's, which by the commotion it made in the water, lost her } \\
\text { rudder, split her pump and fore-top, and was so shook that the captain was } \\
\text { afraid she would have gone in pieces. } \\
\text { (Cotte, 1807): Earthquake at St. Christopher in the Americas, July 11, } 1785 . \\
\text { (Perrey, 1847): It was felt in St. Christopher. }\end{array}$ & $\mathrm{CHF}(4)$ \\
\hline-62.9765 & 17.4890 & St. Eustatius & $\begin{array}{l}\text { (McCann and others, 2011, quoting The Times of London, Sept. 15, 1785): Extract } \\
\text { of a letter from St. Eustatia, dated July 22nd, 1785: On Monday morning, } \\
\text { the 11th instant, about half after two o'clock, we were much alarmed here } \\
\text { by a violent shock of an earthquake which lasted upwards of a minute. As I } \\
\text { in general sleep very sound, I believe I should not have felt it, had I not } \\
\text { been waked by shrieks of the ladies of the house } * * * \text { The bed shook almost } \\
\text { like the rocking of a cradle and the house rattled } * * * \text { It however went off } \\
\text { without doing any damage. They say here they have not felt so severe a } \\
\text { shock these } 40 \text { years. }\end{array}$ & $\mathrm{CHF}(4)$ \\
\hline-61.8456 & 17.1176 & St. John, Antigua & $\begin{array}{l}\text { (McCann and others, 2011, quoting The Times of London, Sept. 8, 1785): St. } \\
\text { Johns letter dated July 12, "About three o'clock yesterday morning we had } \\
\text { the most violent shock of an earthquake that has been know in the memory } \\
\text { of the oldest inhabitant here. ** I was awoken suddenly by an unusual } \\
\text { noise } * * * \text { Three or four minutes; after } * * * \text { poor hound in the yard began } \\
\text { to howl, and the poultry to make a noise *** in an instant the whole house } \\
\text { was in a gentle trembling, which continued about half a minute. Before I } \\
\text { could get out of bed for a candle *** another dreadful shock succeeded. } \\
\text { The house was rocked like a cradle for nearly three minutes. The windows, } \\
\text { and some glasses were in a perfect clatter, and a dismal noise accompanied } \\
\text { the earthquake. It has done no material damage on this island, except } \\
\text { injuring some old houses } * * \text { The shock it seems was felt severely at sea, } \\
\text { many leagues from the land". } \\
\text { (Perrey, 1847): At Antigua, disastrous shaking. }\end{array}$ & $\mathrm{CHF}(5)$ \\
\hline
\end{tabular}




\begin{tabular}{|l|l|l|l|l|}
\hline \multicolumn{2}{|l|}{ July 11, 17855 } & & $\begin{array}{l}\text { (Gentleman's Magazine, 1785): On the 11th of July, about three in the } \\
\text { morning, a dreadful earthquake shook the Island of Antigua to its } \\
\text { foundation. It threw the inhabitants into the utmost consternation but no } \\
\text { material damage ensued. }\end{array}$ \\
\hline-72.2006 & 19.7616 & Cap Haitien, Hispaniola & $\begin{array}{l}\text { (Moreau de St. Méry, 1798): We had three in } 1785 * * * \text { the third and } \\
\text { strongest on July 10 in the night. }\end{array}$ \\
\hline-72.0223 & 19.6186 & Trou-du-Nord, Hispaniola & $\begin{array}{l}\text { (Moreau de St. Méry, 1798): It was felt fifteen earthquakes in these four years, } \\
\text { two of which were sensibly felt, June 18, 1784 and July 11, 1785. They } \\
\text { undulated from West to East and their motion vibratory. }\end{array}$ \\
\hline
\end{tabular}

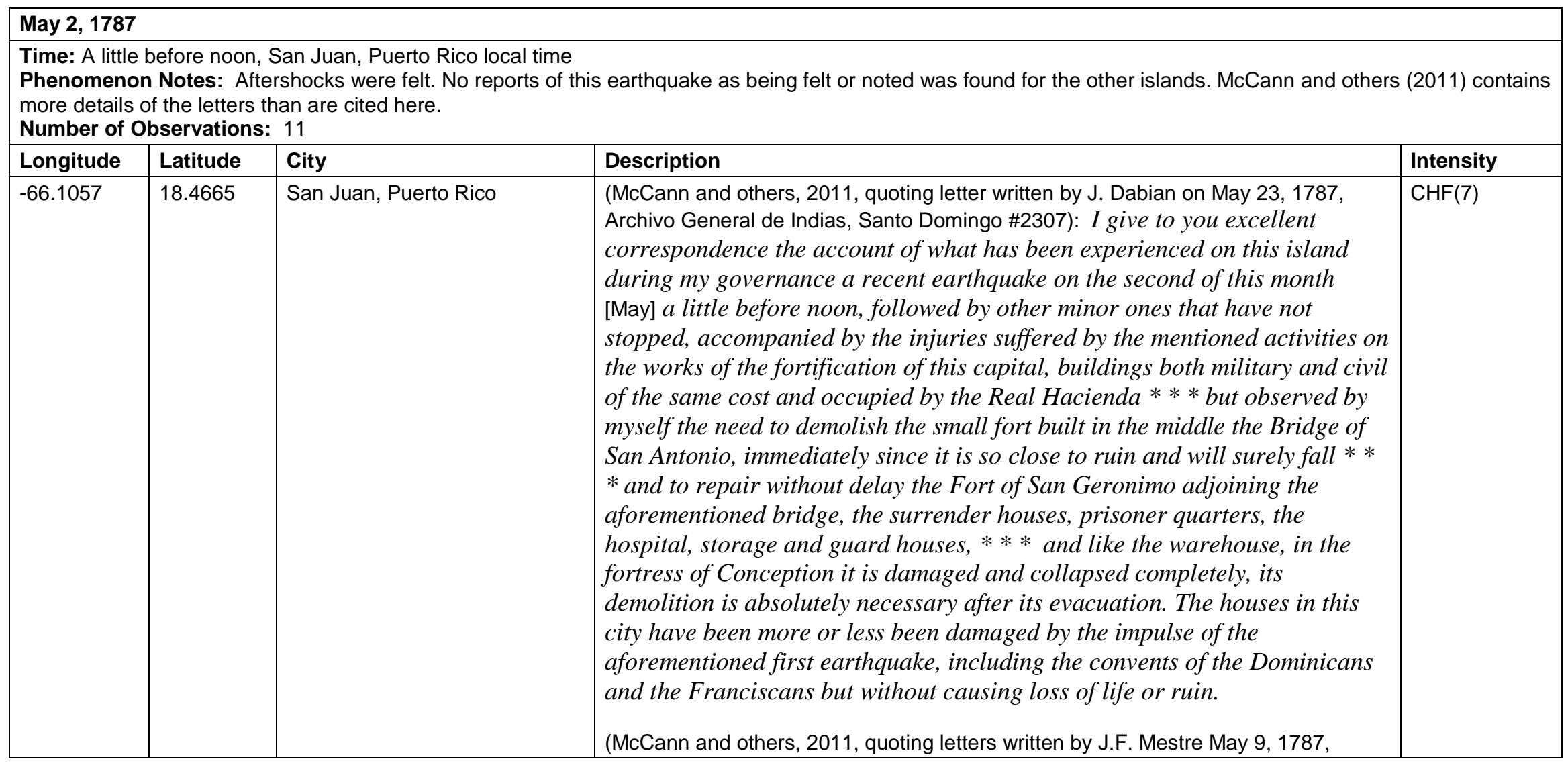




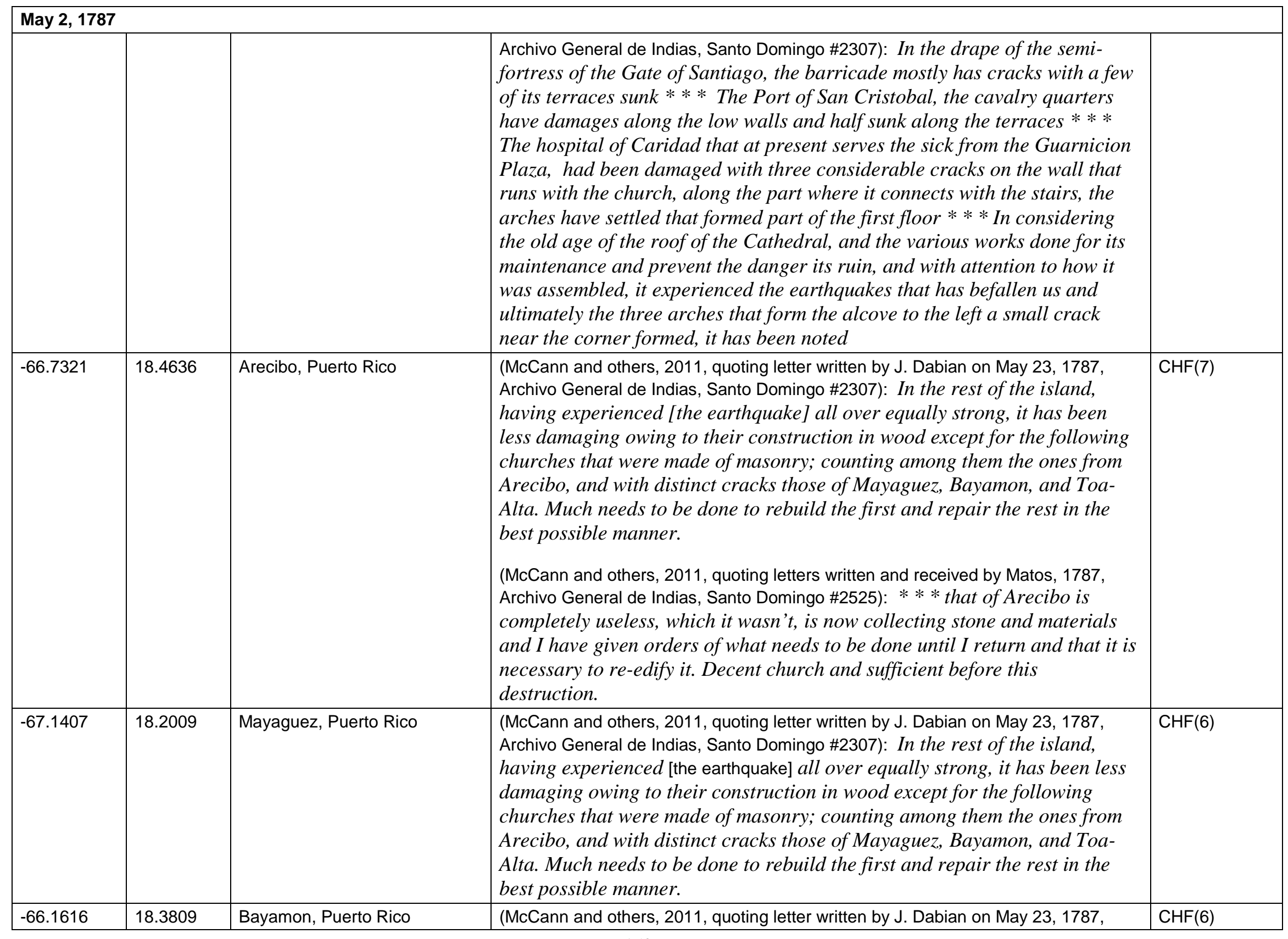




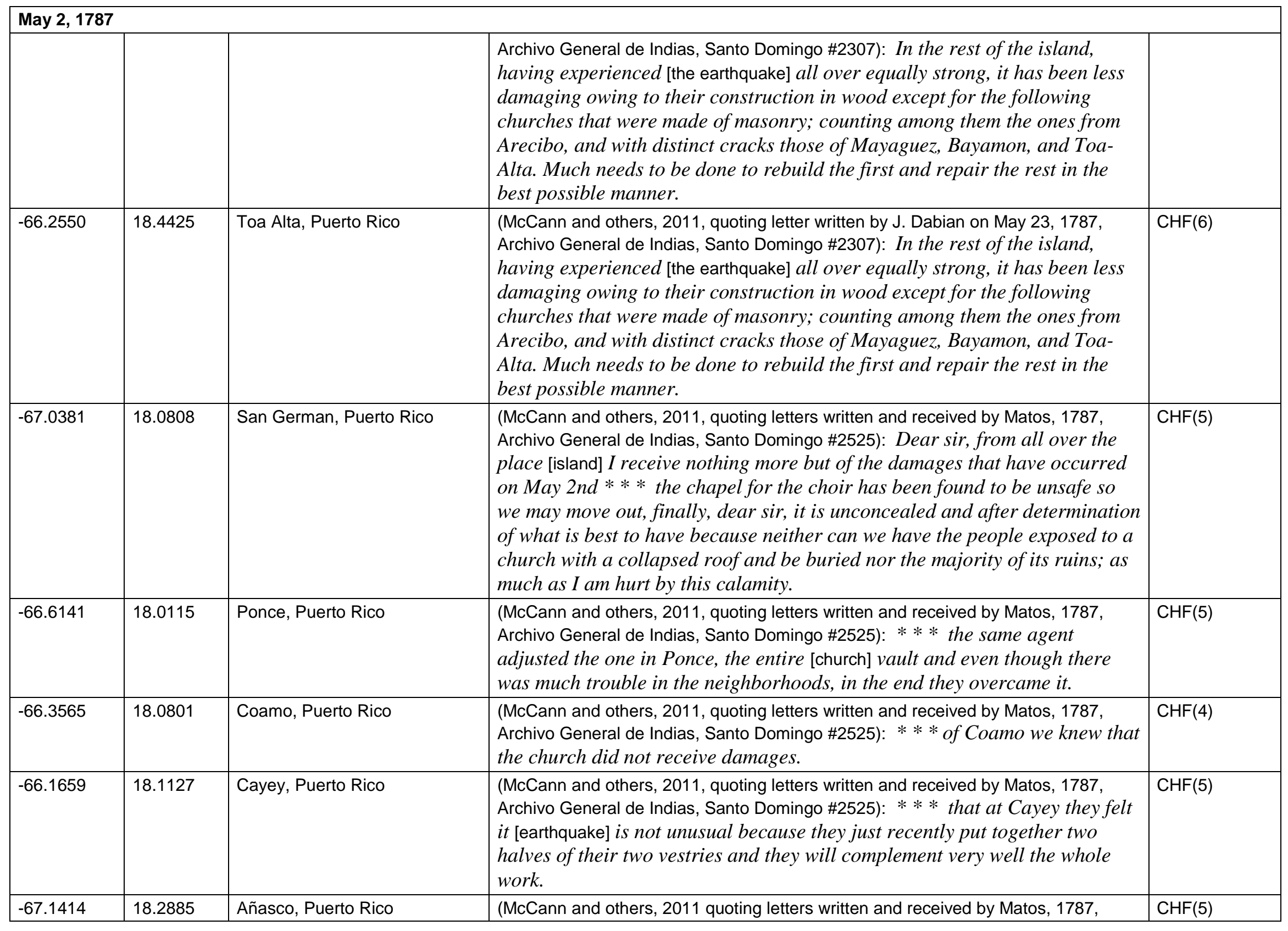




\begin{tabular}{|l|l|l|l|}
\hline \multicolumn{2}{|l|}{ May 2, 1787} & & $\begin{array}{l}\text { Archivo General de Indias, Santo Domingo \#2525): *** those of Añasco have } \\
\text { taken shelter in Yaguas. }\end{array}$ \\
\hline-66.0347 & 18.2344 & Caguas, Puerto Rico & $\begin{array}{l}\text { (McCann and others, 2011 quoting Cordova, 1968): The church at Arecibo was } \\
\text { ruined, and those of Mayaguez, Caguas, and Toa Alta their walls were } \\
\text { cracked. }\end{array}$ \\
\hline
\end{tabular}

\section{Lesser Antilles}

Intensity, Mercalli Magnitude Intensities (3-10); CHF, assigned by C. H. Flores (author); WHB, assigned by W. H. Bakun (co-author); SISF, assigned by SisFrance/Antilles (2010); L\&S1995, assigned by Lynch and Shepherd (1995); S\&L1992, assigned by Shepherd and Lynch (1992); T\&R1977, assigned by Tomblin and Robson (1977); T\&A1975, assigned by Tomblin and Aspinall (1975); R1974, assigned by Robson (1964); - , no intensity assigned.

\begin{tabular}{|c|c|c|c|c|}
\hline \multicolumn{5}{|c|}{ April 5, 1690} \\
\hline \multicolumn{5}{|c|}{$\begin{array}{l}\text { Time: Between } 4 \text { and } 5 \text { in the afternoon, Antigua local time. } \\
\text { Phenomenon Notes: None } \\
\text { Number of Observations: } 11\end{array}$} \\
\hline Longitude & Latitude & City & Description & Intensity \\
\hline-61.8003 & 17.0864 & Antigua & $\begin{array}{l}\text { (Shepherd and Lynch, 1992, quoting Colonial Records Office, London): Antigua, } \\
\text { having more stone houses suffered much, most of the houses being either } \\
\text { shaken down or being so split and cracked that they will have to be taken } \\
\text { down. } \\
\text { (Robson, 1964, quoting the Calendar State Papers, 1689-1692, 1901): Between } \\
\text { four and five in the afternoon a terrible earthquake "laid some*** } \\
\text { buildings in rubbish and killed some persons". Governor Codrington lost } \\
\text { property to the value of } £ 2000 \text {. Aftershocks almost daily for a month: } \\
\text { further aftershocks in June... }\end{array}$ & $\begin{array}{l}\text { CHF(8) } \\
\text { WHB(8) } \\
\text { SISF(7.5) } \\
\text { S\&L1992(8) } \\
\text { R1964(9) }\end{array}$ \\
\hline-62.3414 & 16.9419 & Redonda & $\begin{array}{l}\text { (Shepherd and Lynch, 1992, quoting Colonial Records Office, London): A rocky } \\
\text { islet called Rockadunda was a great part of it split and turned into the sea. } \\
\text { (Oldmixon, 1741): Others passing the uninhabited island, or rather rock, } \\
\text { called Redunda, found the earthquake so violent there, that a great part of } \\
\text { that rocky isle split and tumbled into the sea where it was sunk, making as } \\
\text { loud a noise as if several cannon had been fired. A very great cloud of dust } \\
\text { ascended into the air at the fall. }\end{array}$ & $\begin{array}{l}\text { CHF(8) } \\
\text { WHB } \\
\text { SISF(7) } \\
\text { S\&L1992(8) }\end{array}$ \\
\hline-62.1899 & 16.7376 & Montserrat & $\begin{array}{l}\text { (Shepherd and Lynch, 1992, quoting Colonial Records Office, London): And yet } \\
\text { felt as severely (as in Antigua) in Montserrat. }\end{array}$ & $\begin{array}{l}\mathrm{CHF}(8) \\
\mathrm{WHB}(8)\end{array}$ \\
\hline
\end{tabular}




\begin{tabular}{|c|c|c|c|c|}
\hline \multicolumn{5}{|c|}{ April 5, 1690} \\
\hline & & & & \begin{tabular}{|l|} 
SISF(7) \\
S\&L1992(8)
\end{tabular} \\
\hline-62.5894 & 17.1541 & Nevis & $\begin{array}{l}\text { (Smith, 1745): *** the foundation [fountain] rock in the lower part of the } \\
\text { town, bursting at the same instant and casting out a considerable quantity of } \\
\text { water; and indeed some of the marks of this bursting were visible enough in } \\
\text { my time. This Convulsion was on a Sunday in the afternoon, whilst some } \\
\text { of my parishioners were drinking a bowl of rum punch, which one of them } \\
\text { had then in his hand, in order to set it down upon the table* ** he assured } \\
\text { me he did not spill a single drop, though the bowl was two thirds full. A } \\
\text { huge piece of our Nevis Mountain...fell down and left a monstrous rocky } \\
\text { spot of it quite naked and bare, which continues in that state to this very day } \\
\text { (about } 20 \text { years later). } * * \text { No one has lost his life by this earthquake. } \\
\text { (Oldmixon, 1741): On Sunday the 6th of April, about } 5 \text { a clock in the evening, } \\
\text { a strange hollow noise was heard for some few minutes, which was thought } \\
\text { to proceed from the great mountain in the middle of this islands. The } \\
\text { inhabitants were surprised and amazed at it; and immediately after, to their } \\
\text { greater amazement, began a mighty earthquake, with so much violence, that } \\
\text { almost all the houses in Charles Town, which were of brick or stone, were } \\
\text { in an instant leveled to the ground, and those built of timber shook. In the } \\
\text { streets the ground in several places clove about a foot asunder, and hot } \\
\text { stinking water spouted out of the earth to a great height } * * * \text { It is usual } \\
\text { almost at every house in this island to have a large cistern to contain the rain } \\
\text { water, of about } 9 \text { or } 10 \text { foot deep and } 15 \text { or } 20 \text { foot diameter, threw out the } \\
\text { water } 8 \text { or } 10 \text { foot high, and the motion of the earth all over the island was } \\
\text { such, that nothing could be more terrible. }\end{array}$ & $\begin{array}{l}\text { CHF(9) } \\
\text { WHB(9) } \\
\text { SISF(7.5) } \\
\text { S\&L1992(8) } \\
\text { R1964(9) }\end{array}$ \\
\hline-62.7494 & 17.3174 & St. Kitts & $\begin{array}{l}\text { (Oldmixon, 1741): } * * * \text { there happened an earthquake here, which was felt in } \\
\text { the other islands. The earth opened nine foot in many places and buried } \\
\text { solid timber, sugar-mills, etc. It threw down the Jesuit College and other } \\
\text { stone buildings. }\end{array}$ & $\begin{array}{l}\text { CHF(8) } \\
\text { WHB(7) } \\
\text { SISF(7.5) } \\
\text { S\&L1992(8) } \\
\text { R1964(9) }\end{array}$ \\
\hline-61.5443 & 16.2539 & Guadeloupe & $\begin{array}{l}\text { (Robson, 1964, quoting Calendar of State Papers, 1689-1692, 1901): The French } \\
\text { islands } * * \text { suffered as severely } * * *\end{array}$ & $\begin{array}{l}\text { CHF(6) } \\
\text { WHB(6) } \\
\text { S\&L1992(6) } \\
\text { R1964(9) } \\
\end{array}$ \\
\hline
\end{tabular}




\begin{tabular}{|c|c|c|c|c|}
\hline \multicolumn{5}{|c|}{ April 5, 1690} \\
\hline & & & & S\&L1992(5 \\
\hline-59.5514 & 13.1556 & Barbados & $\begin{array}{l}\text { (Oldmixon, 1741): In April, } 1690 \text { there was an earthquake at Barbadoes, but it } \\
\text { did no manner of hurt to men or cattle. }\end{array}$ & $\begin{array}{l}\text { CHF(3) } \\
\text { WHB(3) } \\
\text { S\&L1992(3) }\end{array}$ \\
\hline
\end{tabular}

\section{February 8, 1843}

Time: Between 10:30 AM Pointe-a-Pitre, Guadeloupe local time and 10:40 AM English Harbour, Antigua local time.

Tsunami: The only report of the sea rushing in is from Antigua.

Land Surface Effects: Crevasses were observed as well as water gushing out of the ground in coastal areas especially in Guadeloupe.

Phenomenon Notes: The dockyard of English Harbour, Antigua, sank. Wells were observed to have dried up in Guadeloupe. Point-a-Pitre was completely

destroyed partly from the earthquake but also from the immediate fires. Also, the governor of Guadeloupe claims that the earthquake lasted 70 seconds (Gourbeyre, 1843). Many publications concerning this earthquake were written in the scientific literature including those of Charles Joseph Sainte-Claire Deville in which he did a reconnaissance of the islands and recorded the land surface effects and a list of aftershock sequence, and republished some of the eyewitness accounts. There are newspaper accounts of claims the effects of this earthquake were felt as far north as Bermuda and South Carolina and as far south as French and British Guiana colonies on the northern coast of South America.

Number of Observations: 43

\begin{tabular}{|l|l|l|l|l|}
\hline Longitude & Latitude & City & Description & Intensity \\
\hline-61.7652 & 17.0073 & English Harbour, Antigua & $\begin{array}{l}\text { (Helmsley, 1843): The Dockyard at English Harbour is sunk considerably, } \\
\text { many parts being under water, the whole of the stone houses in a complete } \\
\text { ruinous state, the walls partly or wholly down; the water tanks containing } \\
\text { nearly 11,000 tons of water burst with an awful crash; the Earthquake lasted } \\
\text { about 4 minutes. Mr. Hart, Clerk in charge of the Dockyard, English } \\
\text { S\&L1992(9- } \\
\text { Harbour, states that 3 clocks in the neighborhood stopped at 10h: } 40 \mathrm{~m} \text { : a.m. } \\
\text { Precise accounts had not been received from the interior. It is ascertained 40 } \\
\text { lives had been lost - tears [?] were entertained it was short of the actual loss. } \\
\text { The Governor's house (Dows Hill) is partially destroyed with nearly all its } \\
\text { furniture; the Ridge Barracks much damaged; the Custom House, Court } \\
\text { House, and Wesleyan Meeting House destroyed. }\end{array}$ \\
\end{tabular}




\begin{tabular}{|c|c|c|c|c|}
\hline \multicolumn{5}{|c|}{ February 8, 1843} \\
\hline & & & $\begin{array}{l}\text { (Barbadian, 1843a): The Town, I am told, presents one scene of destruction, } \\
* * * \text { My poor friend } * * * \text { in the pride of human wisdom, thought that he } \\
\text { would provide for future casualties, and erected a fire-proof store all of } \\
\text { arches at the expense of } £ 1000 \text { sterling, and, in one moment it was a heap of } \\
\text { ruins, } * * * \text { The dock yard, which was the wharf [?] of Antigua, has been so } \\
\text { cracked, and the pier so sunk, as to be rendered almost useless, the } \\
\text { estimated expense of repair is upwards of } £ 50,000 \text { sterling. The Garrison } \\
\text { shared a similar fate, as the barracks were in such a state as to be } \\
\text { uninhabitable. The troops are under canvass - in fact almost all our houses } \\
\text { present the appearance of an umbrella, the roofs standing, but the houses } \\
\text { gutted. }\end{array}$ & \\
\hline-61.8456 & 17.1176 & St. John's, Antigua & $\begin{array}{l}\text { (Helmsley, 1843): The organ in the Church of St. John's totally destroyed. } \\
\text { (Barbadian, 1843a): The Governor, who has been residing out here, has been } \\
\text { forced to abandon Dow's Hall, after having lost the greater part of his } \\
\text { furniture; fortunately for him the Government House in St. John's is a } \\
\text { wooden building, and is safe. }\end{array}$ & $\begin{array}{l}\text { CHF(8) } \\
\text { WHB(8) } \\
\text { SISF(9) } \\
\text { S\&L1992(9) }\end{array}$ \\
\hline
\end{tabular}




\begin{tabular}{|c|c|c|c|c|}
\hline \multicolumn{5}{|c|}{ February 8, 1843} \\
\hline & & & $\begin{array}{l}\text { Thousands were buried among the ruins and living and raising their voices } \\
\text { for [?], many were saved; but alas, the work of destruction was not yet } \\
\text { finished; a cry of fire was heard, which proved to be true; what the } \\
\text { Earthquake and water had begun, the Fire finished. }\end{array}$ & \\
\hline-61.7281 & 15.9960 & Basse-Terre, Guadeloupe & $\begin{array}{l}\text { (Gourbeyre, 1843): At Basse-Terre, many gables are fallen; many houses } \\
\text { strongly shaken are uninhabitable and must be demolished; fortunately } \\
\text { nobody perished. }\end{array}$ & $\begin{array}{l}\text { CHF(8) } \\
\text { WHB(8) } \\
\text { SISF(8) }\end{array}$ \\
\hline-61.5834 & 15.8661 & $\begin{array}{l}\text { Iles de Saintes } \\
\text { (Terre-de-haut), Guadeloupe }\end{array}$ & $\begin{array}{l}\text { (Barbadian, 1843c): The dependencies of The Saints and Marie-Galante have } \\
\text { also suffered. The first was shaken with much violence, and some of the } \\
\text { houses on the high lands thrown down; of the disasters on the lower lands, } \\
\text { we are as yet ignorant. The new military establishment at I'lera Cantit[?] } \\
\text { has been thrown down and the powder magazine destroyed. At Marie } \\
\text { Galante, half of the town is down, that is to say, all the stone houses, } \\
\text { barracks, coals [?], and churches. } \\
\text { (Gourbeyre, 1843): For Saintes, all the houses made of masonry were thrown } \\
\text { down. }\end{array}$ & $\begin{array}{l}\text { CHF(8) } \\
\text { WHB(8) } \\
\text { SISF(8) }\end{array}$ \\
\hline-61.3453 & 16.3310 & Le Moule, Guadeloupe & $\begin{array}{l}\text { (Gourbeyre, 1843): All the quarters in the colony has suffered destruction. } \\
\text { The town Monte destroyed. They deplore the death of } 30 \text { inhabitants. The } \\
\text { countryside near the city was afflicted with similar calamity. In the } \\
\text { boroughs of Saint-Francois, Saint-Anne, Port Louis, Bernard Bay, Sainte- } \\
\text { Rose were damaged; dead or injured almost everywhere. }\end{array}$ & $\begin{array}{l}\text { CHF(9) } \\
\text { WHB(9) } \\
\text { SISF(9) }\end{array}$ \\
\hline-61.5914 & 16.1940 & Petit-Bourg, Guadeloupe & (Gourbeyre, 1843): Petit-Bourg is destroyed. & $\begin{array}{l}\text { CHF(9) } \\
\text { WHB(9) } \\
\text { SISF(9) }\end{array}$ \\
\hline
\end{tabular}




\begin{tabular}{|c|c|c|c|c|}
\hline \multicolumn{5}{|c|}{ February 8, 1843} \\
\hline & & & Rose were damaged; dead or injured almost everywhere. & \\
\hline-61.3809 & 16.2274 & Sainte-Anne, Guadeloupe & $\begin{array}{l}\text { (Gourbeyre, 1843): All the quarters in the colony has suffered destruction. } \\
\text { The town Monte destroyed. They deplore the death of } 30 \text { inhabitants. The } \\
\text { countryside near the city was afflicted with similar calamity. In the } \\
\text { boroughs of Saint-Francois, Saint-Anne, Port Louis, Bernard Bay, Sainte- } \\
\text { Rose were damaged; dead or injured almost everywhere. }\end{array}$ & $\begin{array}{l}\text { CHF(8.5) } \\
\text { SISF(9) }\end{array}$ \\
\hline-61.6970 & 16.3334 & Sainte-Rose, Guadeloupe & $\begin{array}{l}\text { (Gourbeyre, 1843): All the quarters in the colony has suffered destruction. } \\
\text { The town Monte destroyed. They deplore the death of } 30 \text { inhabitants. The } \\
\text { countryside near the city was afflicted with similar calamity. In the } \\
\text { boroughs of Saint-Francois, Saint-Anne, Port Louis, Bernard Bay, Sainte- } \\
\text { Rose were damaged; dead or injured almost everywhere. }\end{array}$ & $\begin{array}{l}\text { CHF(8.5) } \\
\text { SISF(9) }\end{array}$ \\
\hline-61.2744 & 16.2520 & Saint-Francois, Guadeloupe & $\begin{array}{l}\text { (Gourbeyre, 1843): All the quarters in the colony has suffered destruction. } \\
\text { The town Monte destroyed. They deplore the death of } 30 \text { inhabitants. The } \\
\text { countryside near the city was afflicted with similar calamity. In the } \\
\text { boroughs of Saint-Francois, Saint-Anne, Port Louis, Bernard Bay, Sainte- } \\
\text { Rose were damaged; dead or injured almost everywhere. }\end{array}$ & $\begin{array}{l}\text { CHF(8.5) } \\
\text { SISF(9) }\end{array}$ \\
\hline
\end{tabular}




\begin{tabular}{|c|c|c|c|c|}
\hline \multicolumn{5}{|c|}{ February 8,1843} \\
\hline & & & $\begin{array}{l}\text { stood up in the centre of the yard, expecting every moment when the ground } \\
\text { would open and Charlestown be swallowed up, and its inhabitants ushered } \\
\text { into eternity. Thank Heaven it passed; and though Charlestown is almost in } \\
\text { ruins, it stands and not a life has been lost and scarcely any personal } \\
\text { accident of any kind has happened to any one } * * * \text { My house, which is as } \\
\text { you know, a wooden one, has sustained no damage; but all the wall of the } \\
\text { servants rooms which forms one entire side of them is down, also the } \\
\text { greatest part of the kitchen (very lately put up) and the wall which divides } \\
\text { the premises from Lennington's (formerly the Smith's). }\end{array}$ & \\
\hline-62.2193 & 16.7060 & Plymouth, Montserrat & $\begin{array}{l}\text { (Helmsley, 1843): Wesleyan Meeting House so much injured must be taken } \\
\text { down, the whole of the Mils on the Sugar Estates unfit for use, several large } \\
\text { fissures (from land slips) appear on the sides of the Hills, lasted } 2 \text { minutes, } \\
\text { six lives lost, the whole of the Stone buildings more or less injured and at } \\
\text { present not inhabitable. }\end{array}$ & $\begin{array}{l}\text { CHF(8.5) } \\
\text { WHB(7) } \\
\text { SISF(8.5) } \\
\text { S\&L1992(9) }\end{array}$ \\
\hline-62.7147 & 17.2969 & Basseterre, St. Kitts & $\begin{array}{l}\text { (Helmsley, 1843): Houses much shaken but not materially injured lasted } 3 \\
\text { minutes. } \\
\text { (Barbadian,1843b): Basseterre Church irreparably injured. The Churches of } \\
\text { St. Peter's St. Mary's, Cayon, P. Point, Old Road, and Sandy Point are } \\
\text { materially injured. The Town of Basseterre has suffered severely. Wall } \\
\text { House in the square down. Part of the Reading House - Mr. Mathew's Store } \\
\text { - all down. The House occupied by the Director of the West India Bank } \\
\text { nearly down, and every stone building in Town so much injured, that it will } \\
\text { be necessary to take down many of them. One house in Town partly sunk } \\
\text { into the cellar. All the estates throughout the island much injured. Steam } \\
\text { Engines, Boiling Houses, Dwelling Houses, and Works, leveled with the } \\
\text { earth. The works of the Bevon Island Estate thrown into a ravine below } \\
\text { them. The loss of property in stores, furniture, \&c. very great. Four Mile } \\
\text { Bridge undermined - St. Vincent Observer, Feb. } 14 \text {. }\end{array}$ & $\begin{array}{l}\text { CHF(8) } \\
\text { WHB(7) } \\
\text { SISF(8) } \\
\text { S\&L1992(9) }\end{array}$ \\
\hline-62.8000 & 17.3199 & Old Road, St. Kitts & $\begin{array}{l}\text { (Barbadian, 1843b): The Churches of St. Peter's St. Mary's, Cayon, P. Point, } \\
\text { Old Road, and Sandy Point are materially injured. All the estates } \\
\text { throughout the island much injured. Steam Engines, Boiling Houses, } \\
\text { Dwelling Houses, and Works, leveled with the earth. The loss of property in } \\
\text { stores, furniture, \&c. very great. - St. Vincent Observer, Feb. } 14 \text {. }\end{array}$ & $\begin{array}{l}\text { CHF(7.5) } \\
\text { SISF(8) }\end{array}$ \\
\hline
\end{tabular}




\begin{tabular}{|c|c|c|c|c|}
\hline \multicolumn{5}{|c|}{ February 8, 1843} \\
\hline & & & $\begin{array}{l}\text { throughout the island much injured. Steam Engines, Boiling Houses, } \\
\text { Dwelling Houses, and Works, leveled with the earth. - St. Vincent } \\
\text { Observer, Feb. 14. }\end{array}$ & SISF(8) \\
\hline-61.2565 & 15.4411 & Castle Bruce, Dominica & $\begin{array}{l}\text { (Dominican, 1843b): The chimneys of the boiling and still houses were both } \\
\text { thrown down, the former fell upon the roof and in part crushed it in - part } \\
\text { of the east end of the curing house wall is thrown down, the north wall of } \\
\text { the Little House is split literally from top to bottom, the walls are otherwise } \\
\text { much injured and must be taken down in part and rebuilt after crop is } \\
\text { gathered in, the Mill House is rent and much shaken and must also in part } \\
\text { be rebuilt. }\end{array}$ & $\begin{array}{l}\text { CHF(7) } \\
\text { WHB(7) } \\
\text { SISF(7) }\end{array}$ \\
\hline-61.4616 & 15.5532 & Picard, Dominica & $\begin{array}{l}\text { (Dominican, 1843b): At this place the sugar works have been shaken to their } \\
\text { foundation; and the chimneys rendered quite unsafe. These will have to be } \\
\text { rebuilt as soon as the present crop is taken off } * * * \text { York Valley Estate - } \\
\text { We commence then by stating that the dwelling house of the York Valley } \\
\text { Estate has been rendered uninhabitable: the Works however have been but } \\
\text { slightly shaken } * * * \text { Layon[?] Valley and Prince Ruperts - No serious injury } \\
\text { has been done to the other Estates in the Layon Valley, nor to any other on } \\
\text { the Leeward coast as far as to Prince Ruperts. }\end{array}$ & $\begin{array}{l}\mathrm{CHF}(7.5) \\
\text { WHB(6) }\end{array}$ \\
\hline
\end{tabular}




\begin{tabular}{|c|c|c|c|c|}
\hline \multicolumn{5}{|c|}{ February 8, 1843} \\
\hline-61.4519 & 15.5707 & Sugar Loaf, Dominica & $\begin{array}{l}\text { (Dominican, 1843b): The chimneys of the sugar works and distilleries } \\
\text { together with the walls of a Blacksmith Shop, stables, pens, stock houses, } \\
\text { \&c. have been thrown to the ground - a mass of ruins! and the boiling house } \\
\text { so shaken that part has already been taken down. It must be rebuilt after } \\
\text { crop. }\end{array}$ & $\begin{array}{l}\mathrm{CHF}(7.5) \\
\operatorname{WHB}(7)\end{array}$ \\
\hline-61.2977 & 15.5575 & Londonderry, Dominica & $\begin{array}{l}\text { (Dominican, 1843b): The whole of the Sugar works, Curing houses, } \\
\text { distilleries, store rooms, with chimneys, boilers \&c. have been leveled to the } \\
\text { ground. There is not a Stone building on this property which has not either } \\
\text { been totally or partially destroyed. }\end{array}$ & $\begin{array}{l}\mathrm{CHF}(7) \\
\operatorname{WHB}(7)\end{array}$ \\
\hline-61.2828 & 15.5211 & $\begin{array}{l}\text { Hutton Garden } \\
\text { (Hatton Garden), Dominica }\end{array}$ & $\begin{array}{l}\text { (Dominican, 1843b): The state of the Hutton Garden estate is portrayed in the } \\
\text { following extract of a letter in the last Colonist: - "Our Works were in full } \\
\text { play, making sugar when the Earthquake commenced, in a few seconds I } \\
\text { observed part of the wall of the Mill House falling and the roof (of slate) } \\
\text { with it - at the same time the chimney of the boiling house, part of the wall } \\
\text { of the still house, and curing house, were tumbling in, and clouds of dust, } \\
\text { then arose as if the whole buildings were demolished. Fortunately, the roofs } \\
\text { of the boiling curing and still houses remain up. The back part of the wall } \\
\text { of the boiling house, is so rent and shattered, that it must be taken down by } \\
\text { degrees and rebuilt, I may say the same of the great part of the curing and } \\
\text { still houses, it being unsafe for any person to remain in them, I am glad to } \\
\text { say the horse stable, though in mason work, has not suffered, my house } \\
\text { fortunately is built of wood, but rest on a breast wall, which has given way } \\
\text { in several places, my kitchen walls partly thrown down. - I observed that } \\
\text { earth is cracked within six feet of my house, and ready to slide away, so } \\
\text { violent was the shock of the Earthquake, that the trash was thrown from off } \\
\text { of several of our negro houses." }\end{array}$ & $\begin{array}{l}\mathrm{CHF}(7) \\
\operatorname{WHB}(7)\end{array}$ \\
\hline-61.3068 & 15.5709 & Eden, Dominica & $\begin{array}{l}\text { (Dominican, 1843b): Chimney and boiling house down and walls partly } \\
\text { injured, thanks be to God no lives lost here. }\end{array}$ & $\begin{array}{l}\text { CHF(7) } \\
\text { WHB(7) }\end{array}$ \\
\hline-61.3856 & 15.2977 & Roseau, Dominica & $\begin{array}{l}\text { (Dominican, 1843a): The inhabitants of Roseau were, at seven minutes to } \\
\text { Eleven o'clock this forenoon, suddenly and justly alarmed beyond all } \\
\text { description by the terrible shock of an earthquake which for violence the } \\
\text { oldest of them say, has not even been exceeded here which its duration was } \\
\text { longer than they ever experienced! As far as the agitated mind of everyone } \\
\text { in town can at this moment calculate the violation rocked from NE. to the } \\
\text { S.W. producing a roaring noise like a hurricane, and afterwards the ground } \\
\text { seemed to heave perpendicularly, shaking the houses with a cracking noise }\end{array}$ & $\begin{array}{l}\text { CHF(7) } \\
\text { WHB(7) } \\
\text { SISF(7) } \\
\text { S\&L1992(8) }\end{array}$ \\
\hline
\end{tabular}




\begin{tabular}{|c|c|c|c|c|}
\hline \multicolumn{5}{|c|}{ February 8, 1843} \\
\hline & & & $\begin{array}{l}\text { similar to that heard when a roof is being unshingled. At the same moment } \\
\text { the larger buildings clearly appeared to be rolling to and fro, and columns of } \\
\text { smoke were seen issuing from several of the Mountains in sight of Town. } \\
\text { During the morning as for several days past the sky had been exceedingly } \\
\text { clear and serene. We think the shock lasted } 21 / 2 \text { minutes but one gentleman } \\
\text { assures us that by a watch he had in his hand it occupied three minutes and a } \\
\text { half! In about half a minute from the } * * * \text { almost every house was vacated } \\
\text { leaving the streets covered with the in habitants of every Class, Sex, and } \\
\text { Age. Several Stone buildings have been cracked and some old walls and } \\
\text { chimneys thrown down. The Jail, Police Office, and Roman Catholic } \\
\text { Church are included in the report - At the Militia Arsenal the Arm racks } \\
\text { were so shaken as to bring the Muskets to the floor. - Several messengers } \\
\text { have already reached Town from the neighboring Estates with reports of } \\
\text { accidents to Buildings and of the tumbling down of bodies of earth from the } \\
\text { hills and cliffs but we prefer today confining ourselves to the Town to avoid } \\
\text { mistakes } * * * \text {. }\end{array}$ & \\
\hline-62.8249 & 17.8972 & $\begin{array}{l}\text { St. Barts } \\
\text { (St. Barthelemy) }\end{array}$ & $\begin{array}{l}\text { (Barbadian, 1843c): All the stone houses split - many must be pulled down. } \\
\text { No lives lost. For about a half a-cubit [?] in the town, along the streets, there } \\
\text { was an opening in the ground of about } 10 \text { inches wide. }\end{array}$ & $\begin{array}{l}\text { CHF(6) } \\
\text { WHB(6) } \\
\text { SISF(6) } \\
\text { S\&L1992(8) } \\
\text { T\&R1977(8) } \\
\text { R1964(8) } \\
\end{array}$ \\
\hline-63.0538 & 18.0642 & St. Martin & $\begin{array}{l}\text { (Barbadian, 1843c): Estates all ruined, and stone houses all thrown down - } \\
\text { No lives lost. }\end{array}$ & $\begin{array}{l}\text { CHF(6) } \\
\text { WHB(6) } \\
\text { SISF(5) } \\
\text { S\&L1992(8) } \\
\text { T\&R1977(8) } \\
\text { R1964(8) } \\
\end{array}$ \\
\hline-61.1757 & 14.7405 & St. Pierre, Martinique & $\begin{array}{l}\text { (Barbadian, 1843b): An Earthquake took place at St. Pierre on Wednesday } \\
\text { last, at the hour at which one was felt here; it was marked by the same } \\
\text { tremulous motion, without shock, which characterized its action in this } \\
\text { Colony. The vibrations are said to have continued without interruption for } \\
\text { several minutes. The whole of the inhabitants of St. Pierre fled down to the } \\
\text { sea beach and part of what we understand to be celebrated overhanging }\end{array}$ & $\begin{array}{l}\text { CHF(6) } \\
\text { SISF(7) } \\
\text { S\&L1992(7) }\end{array}$ \\
\hline
\end{tabular}




\begin{tabular}{|c|c|c|c|c|}
\hline \multicolumn{5}{|c|}{ February 8, 1843} \\
\hline-60.9988 & 14.6680 & Martinique & $\begin{array}{l}\text { (Helmsley, 1843): Shaken but no injury in town - the sugar mills a little } \\
\text { damaged. } \\
\text { (Times, 1843): On the 8th, the day of the catastrophe which reduced Point-a- } \\
\text { Pitre to a heap of ruins and ashes, I was going towards the Savannah, about } \\
20 \text { minutes past } 10 \text { o'clock, in order to reach the palace, when I heard cries } \\
\text { of distress coming from every side of me. The people rushed from their } \\
\text { homes, the women carrying their children in their arms, all hurrying to the } \\
\text { open promenade. I then felt the earth tremble under my feet, and began to } \\
\text { hasten my own steps. The shocks continued with increased violence for } \\
\text { nearly two minutes but, fortunately, there was no vertical movement, which } \\
\text { would have inevitably thrown down our houses, as in 1839. We soon } \\
\text { ascertained that our town remained uninjured. }\end{array}$ & \begin{tabular}{l|} 
CHF(6) \\
WHB(6) \\
R1964(7)
\end{tabular} \\
\hline
\end{tabular}




\begin{tabular}{|c|c|c|c|c|}
\hline \multicolumn{5}{|c|}{ February 8, 1843} \\
\hline & & & $\begin{array}{l}\text { other buildings of mason-work, have been cracked, but none materially } \\
\text { injured in the town. Slight shocks were also felt during the night of Tuesday } \\
\text { and last night. - St. Lucia Palladium, February } 9 .\end{array}$ & \\
\hline-61.2290 & 13.1576 & Kingstown, St. Vincent & $\begin{array}{l}\text { (Saint George Chronicle,1843b): One of those awful visitations of providence, } \\
\text { which so frequently occur in these colonies - an earthquake - was } \\
\text { experienced here about half past ten on Wednesday morning last, and } \\
\text { continued for an unusual length of time, probably from a minute to a minute } \\
\text { and a half, though it was by no means so violent as we have before } \\
\text { experienced, and fortunately was silenced with no injury -St. Vincent } \\
\text { Gazette, Feb. } 11 \text {. }\end{array}$ & \begin{tabular}{|l|} 
CHF(4) \\
SISF(6) \\
S\&L1992(5)
\end{tabular} \\
\hline
\end{tabular}




\begin{tabular}{|c|c|c|c|c|}
\hline \multicolumn{5}{|c|}{ February 8, 1843} \\
\hline & & & $\begin{array}{l}\text { earthquake. The vibration of the earth from South to North increased to an } \\
\text { awful degree, and lasted at least a minute and a half. The shock was so } \\
\text { severe as to induce very many persons to run out of their houses. It was } \\
\text { particularly violent on the Wharf and on Broad Street. Many persons were } \\
\text { seized with great nausea at the stomach, some even to vomiting -Barbadian } \\
\text { Feb.8, } 1843 \text {. }\end{array}$ & \\
\hline-61.6798 & 12.1100 & Grenada & $\begin{array}{l}\text { (Barbadian, 1843b): On Wednesday fortnight[?] last, a severe shock of } \\
\text { earthquake was felt here, } 20 \text { minutes before } 11 \text { o'clock and there was too } \\
\text { much probability to suppose that it had extended to the Northern } \\
\text { Islands...Grenada Free Press February } 15 .\end{array}$ & \begin{tabular}{|l|} 
CHF(4) \\
R1964(5)
\end{tabular} \\
\hline-61.2611 & 10.4441 & Trinidad & $\begin{array}{l}\text { (Barbadian, 1843b): A slight shock of Earthquake was felt yesterday in the } \\
\text { Town and Suburbs; the motion was tremulous slow and unbroken, and of } \\
\text { about a minute's duration. Like all similar awful visitations, it caused } \\
\text { anxiety; but as the shock was not repeated, the admonitory warning, as } \\
\text { usual, was speedily forgotten, or disregarded. We [?] hear that what was felt } \\
\text { here was merely the vibration of a much more powerful convulsions at } \\
\text { some distant spot - Trinidad Standard, Feb. 9. }\end{array}$ & $\begin{array}{l}\text { CHF(4) } \\
\text { R1964(3) }\end{array}$ \\
\hline
\end{tabular}




\begin{tabular}{|l|l|l|l|}
\hline February 8, 1843 & & $\begin{array}{l}\text { (Barbadian, 1843b): At ten minutes past eleven o'clock, this forenoon, } \\
\text { occurred as severe an earthquake as some of the oldest inhabitants have any } \\
\text { recollection of. Every moveable in every house was in motion, and every } \\
\text { house shook violently; some old chimney stacks fell; people were seized } \\
\text { with giddiness and nausea, similar to the feelings incidental to incipient sea } \\
\text { sickness. As quickly [?] as conclusion would other persons to judge, the } \\
\text { shock, or rather the two shocks, lasted, altogether, forty seconds. But on } \\
\text { three occasions no man thinks of taking out his watch, and counting time, } \\
\text { for the Philosopher is lost in the helpless and apprehensive human being. - } \\
\text { Guiana Times, February 8. }\end{array}$ \\
\hline-52.3315 & 4.9387 & $\begin{array}{l}\text { Cayenne, Guyane } \\
\text { (French Guiana) } \\
\text { (Sainte-Claire Deville, 1847): We felt a strong earthquake on February 8, at ten } \\
\text { and three quarters** * *for here all the houses are made of wood. }\end{array}$ & $\begin{array}{l}\text { CHF(3) } \\
\text { WHB(3) } \\
\text { SISF(3.5) }\end{array}$ \\
\hline-66.6141 & 18.0115 & Puerto Rico (Ponce) & $\begin{array}{l}\text { (Helmsley, 1843): At the time of the Earthquake the ship was off the island of } \\
\text { Porto Rico, no shock was felt on board. }\end{array}$ \\
\hline
\end{tabular}

\section{October 8, 1974}

Time: 09:50:57.08 UTC earthquake origin time;

Phenomenon Notes: $\left(-61.976^{\circ} \mathbf{W}, \mathbf{1 7 . 3 4 9 ^ { \circ }} \mathrm{N}\right)$ depth $=\mathbf{2 1 . 3} \mathbf{~ k m}, \mathbf{M w}=\mathbf{6 . 9}, \mathbf{M s}=\mathbf{7 . 3}$ (Engdahl and Villaseñor, 2002) According the United States Earthquake report for 1974, this event was not felt in the U.S. Virgin Islands (Coffman and Stover, 1984). Tomblin and Aspinall (1975) did a reconnaissance report of the earthquake and published their results in the Bulletin of the Seismological Society of America. The figure references inside the descriptions also refer to the figures in their publication.

Number of Observations: 19

\begin{tabular}{|l|l|l|l|}
\hline Longitude & Latitude & City & Description \\
\hline-61.8003 & 17.0864 & Antigua & $\begin{array}{l}\text { (Coffman and Stover, 1984): Intensity VIII on Antigua and Barbuda. } \\
\text { (Tomblin and Aspinall, 1975): From an examination of the damage by the } \\
\text { Tuthors, the MM intensity was rated VIII in Antigua and VII in St. Kitts and } \\
\text { Montserrat. * * Nearly all the visible damage outside St. John’s, Antigua, } \\
\text { is also on a line trending approximately north-south, figure } 26 . \text { This line } \\
\text { extends from slight damage at the Anchorage Hotel on the northwest coast, } \\
\text { through the oil refinery, the town of St. John's, the Golden Grove Technical } \\
\text { College, the Creekside Bridge, to the damage at the Ministry of Agriculture } \\
\text { Plant Propagation Station in Christian Valley. Slight damage occurred to } \\
\text { buildings elsewhere on the island but the above line of obvious damage } \\
\text { stands out and demands further study. }\end{array}$ \\
\hline
\end{tabular}




\begin{tabular}{|c|c|c|c|c|}
\hline \multicolumn{5}{|c|}{ October 8, 1974} \\
\hline-61.8456 & 17.1176 & St. John, Antigua & $\begin{array}{l}\text { (Tomblin and Aspinall, 1975): The most severe damage occurred to } \\
\text { unreinforced masonry structures, especially the taller ones. These included } \\
\text { the Anglican Cathedral in St. John's Antigua in which the limestone blocks } \\
\text { were partly dislodged along the mortared joints, or the blocks themselves } \\
\text { fractured in numerous parts of the building, while several of the masonry } \\
\text { columns in the twin towers, figure 3, and sections of the parapet, completely } \\
\text { collapsed, figure } 4 \text {. Similar fracturing and outward bulging of the parapet } \\
\text { wall occurred in the Court House in St. John's, figure 5. At the prison in St. } \\
\text { John's (built in 1735) a complete limestone-block wall fell outward from an } \\
\text { upper floor office, and numerous cells suffered collapse of masonry and } \\
\text { plaster. *** The majority of buildings with reinforced concrete or steel } \\
\text { frames came through the earthquake with superficial, not structural damage. } \\
* * * \text { In the town of St. John's Antigua, several underground cast-iron water } \\
\text { mains, approximately } 10 \text { cm in diameter, were fractured, figure 16, but in } \\
\text { general, supplies were not interrupted. }\end{array}$ & SISF(8) \\
\hline-61.7904 & 17.6357 & Barbuda & $\begin{array}{l}\text { (Coffman and Stover, 1984): Intensity VIII on Antigua and Barbuda. } \\
\text { (Tomblin and Aspinall, 1975): Reports from other islands have been rated at } \\
\text { MM intensity VII in Barbuda, intensity VI in St. Bartholomew and } \\
\text { Guadeloupe, intensity V in Dominica, intensity III in St. Lucia and intensity } \\
\text { II in Puerto Rico. }\end{array}$ & $\begin{array}{l}\text { SISF(7.5) } \\
\text { L\&S1995(7) } \\
\text { T\&A1975(7) }\end{array}$ \\
\hline-62.7494 & 17.3174 & St. Kitts & $\begin{array}{l}\text { (Tomblin and Aspinall, 1975): From an examination of the damage by the } \\
\text { authors, the MM intensity was rated VIII in Antigua and VII in St. Kitts and } \\
\text { Montserrat. }\end{array}$ & $\begin{array}{l}\text { SISF(7) } \\
\text { L\&S1995(7) } \\
\text { T\&A1975(7) }\end{array}$ \\
\hline-62.8031 & 17.3232 & Middle Island, St. Kitts & $\begin{array}{l}\text { (Tomblin and Aspinall, 1975): In St. Kitts, the church at Middle Island was } \\
\text { severely damaged by the collapse of the upper half of the tower through the } \\
\text { roof, figure } 6 \text {. This tower dated } 1860 \text { was an example of one of the poorest } \\
\text { imaginable kinds of construction for a seismically active region. The walls, } \\
\text { about } 60 \mathrm{~cm} \text { thick, consisted of } 10 \text {-cm-thick hewn lava blocks cemented by } \\
\text { very poor mortar to form the outer faces, while the interiors were filled with } \\
\text { loose earth and rounded boulders with no binding agent, figure } 7 \text {. }\end{array}$ & - \\
\hline-62.7147 & 17.2969 & Basseterre, St. Kitts & $\begin{array}{l}\text { (Tomblin and Aspinall, 1975): The Treasury Building at Basseterre, St. Kitts } \\
\text { showed serious cracking and a minor fall of unreinforced masonry from its } \\
\text { block work parapet, figure 8; the Anglican Church in Basseterre suffered a } \\
\text { similar loss of masonry from the crest of its western parapet. }\end{array}$ & - \\
\hline
\end{tabular}




\begin{tabular}{|c|c|c|c|c|}
\hline \multicolumn{5}{|c|}{ October 8, 1974} \\
\hline-62.1899 & 16.7376 & Montserrat & $\begin{array}{l}\text { (Tomblin and Aspinall, 1975): From an examination of the damage by the } \\
\text { authors, the MM intensity was rated VIII in Antigua and VII in St. Kitts and } \\
\text { Montserrat. }\end{array}$ & $\begin{array}{l}\text { SISF(7) } \\
\text { L\&S1995(7) } \\
\text { T\&A1975(7) }\end{array}$ \\
\hline-62.1548 & 16.7467 & Bethel, Montserrat & $\begin{array}{l}\text { (Tomblin and Aspinall, 1975): In Montserrat, similar damage and a minor fall } \\
\text { of blocks, occurred from upper corners of the Bethel Church tower, situated } \\
\text { on the eastern side of the island. }\end{array}$ & - \\
\hline-62.2126 & 16.7056 & Plymouth, Montserrat & $\begin{array}{l}\text { (Tomblin and Aspinall, 1975): Where structural damage had occurred, for } \\
\text { example in reinforced concrete columns } * * * \text { and the National State } \\
\text { Building, Plymouth, Montserrat, it was clear that there had been } \\
\text { overloading of these columns due to inadequate design. }\end{array}$ & - \\
\hline-62.8249 & 17.8972 & $\begin{array}{l}\text { St. Bartholomew } \\
\text { (St. Barthelemy) }\end{array}$ & $\begin{array}{l}\text { (Tomblin and Aspinall, 1975): Reports from other islands have been rated at } \\
\text { MM intensity VII in Barbuda, intensity VI in St. Bartholomew and } \\
\text { Guadeloupe, intensity V in Dominica, intensity III in St. Lucia and intensity } \\
\text { II in Puerto Rico. }\end{array}$ & $\begin{array}{l}\text { L\&S1995(6) } \\
\text { T\&A1975(6) }\end{array}$ \\
\hline-61.5443 & 16.2539 & Guadeloupe & $\begin{array}{l}\text { (Tomblin and Aspinall, 1975): Reports from other islands have been rated at } \\
\text { MM intensity VII in Barbuda, intensity VI in St. Bartholomew and } \\
\text { Guadeloupe, intensity V in Dominica, intensity III in St. Lucia and intensity } \\
\text { II in Puerto Rico. }\end{array}$ & $\begin{array}{l}\text { SISF(6) } \\
\text { L\&S1995(6) } \\
\text { T\&A1975(6) }\end{array}$ \\
\hline-61.3365 & 15.4259 & Dominica & $\begin{array}{l}\text { (Tomblin and Aspinall, 1975): Reports from other islands have been rated at } \\
\text { MM intensity VII in Barbuda, intensity VI in St. Bartholomew and } \\
\text { Guadeloupe, intensity V in Dominica, intensity III in St. Lucia and intensity } \\
\text { II in Puerto Rico. }\end{array}$ & $\begin{array}{l}\text { L\&S1995(5) } \\
\text { T\&A1975(5) }\end{array}$ \\
\hline-60.9719 & 13.9003 & Saint Lucia & $\begin{array}{l}\text { (Tomblin and Aspinall, 1975): Reports from other islands have been rated at } \\
\text { MM intensity VII in Barbuda, intensity VI in St. Bartholomew and } \\
\text { Guadeloupe, intensity V in Dominica, intensity III in St. Lucia and intensity } \\
\text { II in Puerto Rico. }\end{array}$ & $\begin{array}{l}\text { SISF(3) } \\
\text { L\&S1995(3) } \\
\text { T\&A1975(3) }\end{array}$ \\
\hline-65.6382 & 18.3361 & Fajardo, Puerto Rico & (Coffman and Stover, 1984): Intensity V at Fajardo, P.R. & - \\
\hline-66.1137 & 17.9832 & Guayama, Puerto Rico & (Coffman and Stover, 1984): Intensity IV at Guayama, Humacao, and Ponce. & - \\
\hline-65.8265 & 18.1502 & Humacao, Puerto Rico & (Coffman and Stover, 1984): Intensity IV at Guayama, Humacao, and Ponce. & - \\
\hline-66.6141 & 18.0115 & Ponce, Puerto Rico & (Coffman and Stover, 1984): Intensity IV at Guayama, Humacao, and Ponce. & - \\
\hline-65.6120 & 18.2289 & Roosevelt Roads, Puerto Rico & $\begin{array}{l}\text { (Coffman and Stover, 1984): Intensity III at Roosevelt Roads, P.R. U.S. Naval } \\
\text { Station. }\end{array}$ & - \\
\hline
\end{tabular}




\section{List of Events Studied by the Authors}

Table 1. Earthquakes studied further in Bakun and others (2012) and ten Brink and others (2011). [Below are earthquakes studied further using Bakun and Wentworth's $(1997 ; 1999)$ method for estimating Magnitude Intensity on the basis of earthquake damage reports. The publication column indicates where to find the discussion of the results for that earthquake. S, South; Dom. Rep., Dominican Republic; long, longitude; lat, latitude]

\begin{tabular}{|l|c|c|c|c|}
\hline \multicolumn{1}{|c|}{ Event } & $\begin{array}{c}\text { Page number in } \\
\text { this report }\end{array}$ & Publication & $\begin{array}{c}\text { Intensity Location } \\
\text { (long, lat) }\end{array}$ & $\begin{array}{c}\text { Magnitude Intensity } \\
( \pm 1 \text { sigma })\end{array}$ \\
\hline December 2, 1562 & 15 & ten Brink & $-70.68,19.37$ & $7.7 \pm 0.3$ \\
\hline September 7, 1615 & 16 & ten Brink & $\begin{array}{c}\text { S. coast of Dom. } \\
\text { Rep. }\end{array}$ & $7.5 \pm 0.7$ \\
\hline January, 1665 (day unknown) & 17 & ten Brink & $\begin{array}{c}\text { S. coast of Dom. } \\
\text { Rep. }\end{array}$ & $6.8 \pm 0.7$ \\
\hline May 9, 1673 & 18 & ten Brink & $\begin{array}{c}\text { S. coast of Dom. } \\
\text { Rep. }\end{array}$ & $7.3 \pm 0.7$ \\
\hline 1684 (month and day unknown) & 18 & ten Brink & $\begin{array}{c}\text { S. coast of Dom. } \\
\text { Rep. }\end{array}$ & $7.0 \pm 0.7$ \\
\hline April 5, 1690 (Lesser Antilles) & 154 & ten Brink & $-62.51,17.08$ & $7.5 \pm 0.2$ \\
\hline 1691 (month and day unknown) & 19 & ten Brink & $\begin{array}{c}\text { S. coast of Dom. } \\
\text { Rep. }\end{array}$ & $7.5 \pm 0.7$ \\
\hline November 9, 1701 & 20 & Bakun & $-72.65,18.42$ & $6.6 \pm 0.3$ \\
\hline October 18, 1751 & 24 & Bakun & $-70.84,18.36$ & $7.4-7.5 \pm 0.2$ \\
\hline November 21, 1751 & 31 & Bakun & $-72.32,18.54$ & $6.6 \pm 0.2$ \\
\hline June 3, 1770 & 41 & Bakun & $-72.86,18.50$ & $7.5 \pm 0.2$ \\
\hline July 11, 1785 (Puerto Rico) & 149 & ten Brink & $-64.60,19.21$ & $6.9(-0.3,+0.2)$ \\
\hline May 2, 1787 (Puerto Rico) & 151 & ten Brink & $-67.54,17.33$ & $6.9(7.2) \pm 0.2(\mathrm{~d})$ \\
\hline May 7, 1842 & 56 & ten Brink & $-70.80,19.42$ & $7.6(+0.2,-0.1)$ \\
\hline $\begin{array}{l}\text { February 8, 1843 (Lesser } \\
\text { Antilles) }\end{array}$ & 156 & ten Brink & $-61.49,16.34$ & $7.8(-0.2,+0.1)$ \\
\hline April 8, 1860 & & Bakun & $-73.17,18.55$ & $6.3 \pm 0.2$ \\
\hline September 23, 1887 & 73 & ten Brink & $-72.65,19.86$ & $6.7 \pm 0.2$ \\
\hline December 29, 1897 & 81 & ten Brink & $-70.76,19.70$ & $6.5 \pm 0.2$ \\
\hline April 24, 1916 & 90 & ten Brink & $-69.38,19.20$ & $6.8 \pm 0.2$ \\
\hline August 4, 1946 & 126 & Bakun & $-69.80,19.35(\mathrm{a})$ & $7.8 \pm 0.2$ \\
\hline October 28, 1952 & 134 & Bakun, ten Brink & $6.0 \pm 0.2$ \\
\hline $\begin{array}{l}\text { October 8, 1974 (Lesser } \\
\text { Antilles) }\end{array}$ & 143 & 168 & $-61.76,17.36$ (c) & $7.0 \pm 0.2$ \\
\hline (a) & & & & \\
\hline
\end{tabular}

(a) The location of the instrument for measuring intensity for August 4, 1946, is (-68.94, 18.92). (b) The location of the instrument for October 28, 1952, is ( $-73.52,18.51)$ from Sykes and Ewing, (1965). (c) The location of the instrument for October 8, 1974, is $(-61.976,17.349)$. (d) The second magnitude in parenthesis is the estimated magnitude if using the Hispaniola attenuation relationship instead of the one for Puerto Rico and the Virgin Islands; see reference ten Brink and others (2011). 
Table 2. Earthquake Modified Mercalli Intensity Criteria.

[Below is the Modified Mercalli Intensity (MMI) scale used in this catalog and in the research publications Bakun and others (2012) and ten Brink and others (2011). Intensities are modified from Richter (1958) and listed both in Arabic (form used in this catalog) and Roman numerals.]

\begin{tabular}{|c|l|}
\hline MMI & \multicolumn{1}{c|}{ Damage } \\
\hline $9-$ IX & Total destruction \\
\hline $8-$ VIII & Most structures destroyed. Only a few buildings remain standing. \\
\hline 7 - VII & Damage to several structures. Most of the building stock remains standing. \\
\hline $6-$ VI & $\begin{array}{l}\text { Some damage reported for a few significant structures. Damage to the cathedral was often } \\
\text { reported to secure rebuilding funds from Spain. }\end{array}$ \\
\hline $5-$ V & No damage reported. Intensity V, as described in Richter (1958). \\
\hline $4-$ IV & No damage reported. Intensity IV, as described in Richter (1958). \\
\hline $3-$ III & No damage reported. Intensity III, as described in Richter (1958). \\
\hline
\end{tabular}




\section{Maps of the Northern Caribbean}

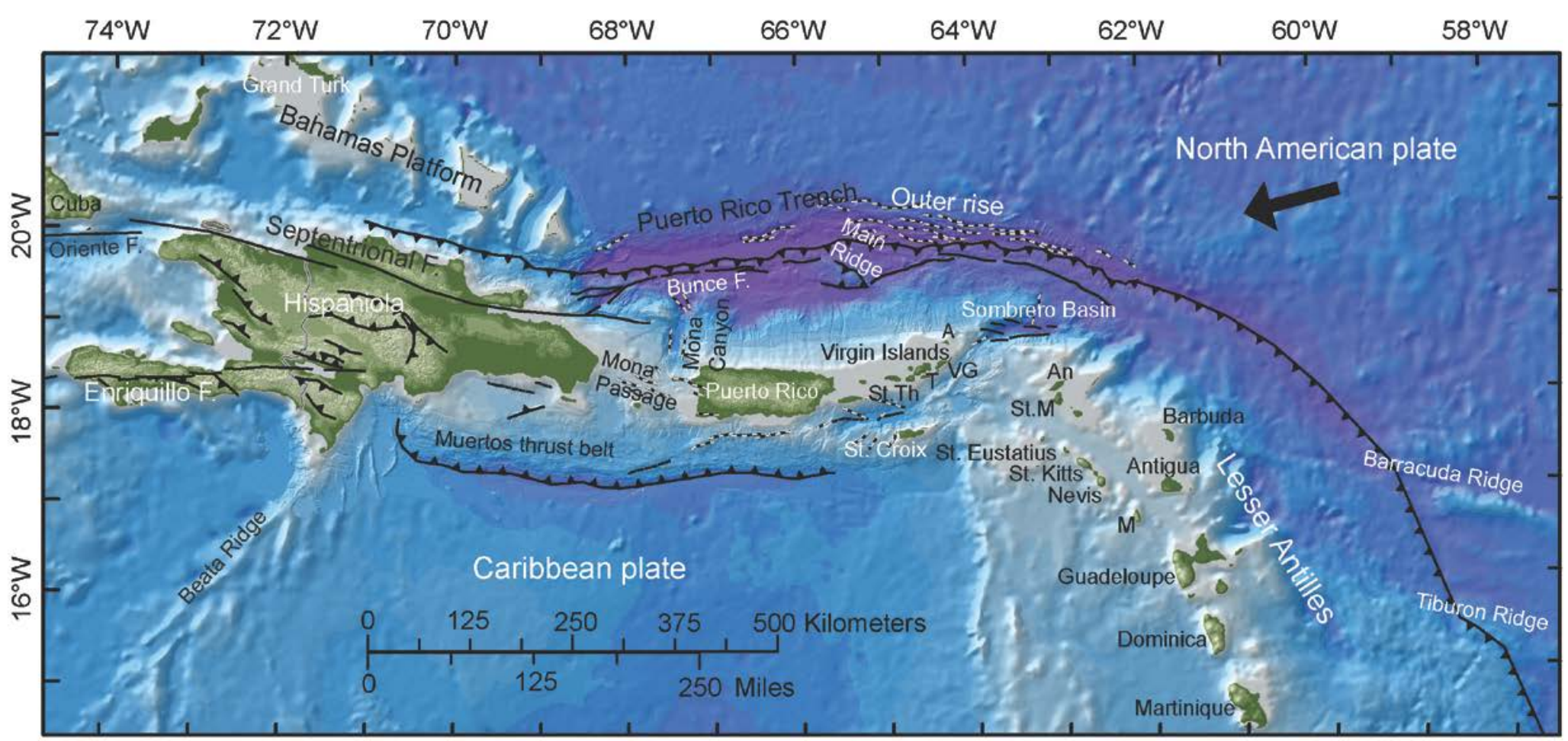

Figure 1. Tectonic map of the northern Caribbean showing the islands of Hispaniola, Puerto Rico, Virgin Islands, and Northern Lesser Antilles. Abbreviated place names on map:

St. $\mathrm{Th}=$ St. Thomas; $\mathrm{T}=$ Tortola; $\mathrm{VG}=$ Virgin Gorda; $\mathrm{A}=$ Anegada; An = Anguilla; St. $\mathrm{M}=$ St. Martin/St. Maarteen; $\mathrm{M}=$ Montserrat.

EXPLANATION Nhrust fault

= Normal or mixed normal and strike-slip faults

$=$ Strike-slip fault

$\leftarrow$ = Direction of plate motion of the North American Plate with respect to the Caribbean Plate

Figure 1. Tectonic map of the northern Caribbean showing the islands of Hispaniola, Puerto Rico, Virgin Islands, and Northern Lesser Antilles. 


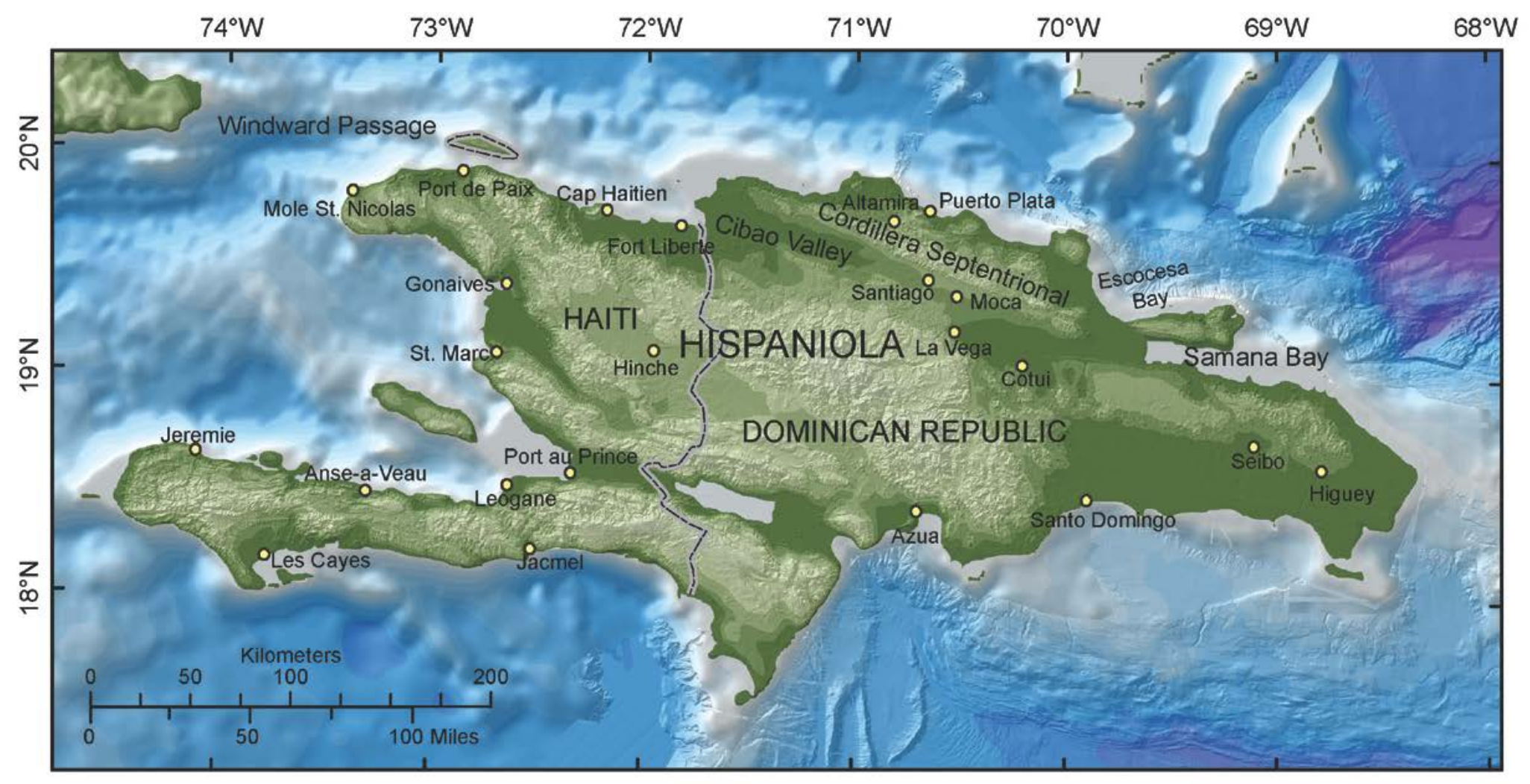

Figure 2. Map of the island of Hispaniola showing the locations of cities and towns with significant populations. The countries of Haiti and Dominican Republic share the island.

Figure 2. Map of the island of Hispaniola showing the locations of cities and towns with significant populations. 


\section{Historical events of interest on the island of Hispaniola}

Various significant political and historical events contribute to the population growth or decline on the island. Changes in population distribution directly affect the availability of eyewitness testimony for any natural hazards, including earthquakes. The list below was compiled using the references of Charlevoix (1731), Garcia (1900), del Monte y Tejada (1890), Hazard (1873), Schoenrich (1918), Ornes (1958), Heinl and Heinl (1978), and Figueredo and Argote-Freyre (2008).

1492 - December 5, 1492 - Discovery of the American continent by Columbus during his first voyage (del Monte y Tejada, 1890; Garcia 1900). La Isabella (de Juan de Aguado) was the site of the first landing by Columbus on the island and the site of the first European settlement. Poland.

1582 - The Gregorian Calendar is adopted by the Catholic nations of Spain, Portugal, France, and

1586 - Invasion of Drake into Santo Domingo on January 10, 1586, in the morning.

1606 - Closing of the ports trading with other countries by the King of Spain. The governor of the island Senor Don Diego Acuna and the archbishop Don Fray Pedro Oviedo carried out the order of the Real Audience of Spain. Puerto de Plata, Monte Cristi, Bayaja, La Iguana (Yaguana), or Santa Maria del Puerto were ordered destroyed. The governor carried out the order in 1606 according to Garcia (1900). Two new towns were created for the coastal populations, San Juan Bautista de Bayaguana (inhabitants from Bayaja and Yaguana) and Monte Plata (inhabitants from Monte Cristi and Puerto Plata).

1608 - Santo Cerro is established.

1630 - Establishments in the island of St. Christopher (today St. Kitts) destroyed by the Spaniards. Refugees settled in Tortuga.

1638 - Governor of Santo Domingo had the settlement of Tortuga attacked and destroyed.

1639- Invasion of the island of Tortuga by the English adventurer Willis.

1655 - Invasion by Admiral William Penn (English) in Santo Domingo May 14, 1655. Sustained many losses and left June 3, proceeded to take Jamaica.

1653 - Count of Penalva, governor, took over Tortuga and built a garrison.

1664 - Port-de-Paix is established.

1673 - Delisle invasion into Puerto Plata (fort) and Santiago.

1678 - French import of African slaves.

1685 - Tentative boundary agreements made between the Spanish and French.

1689 - War between France and Spain over Hispaniola. French burn Santiago to the ground.

1692 - Admiral Perez Caro invades the French side in the plain of La Limonade, kills the French governor and principal officers, exterminates Samana, attacks French settlements.

1695 - English and Spanish fleets join forces; enter Manzanillo Bay, burning and sacking Cape Français (Cape Haitien) and Port-de-Paix.

1697 - Peace Treaty of Ryswick 20 December, 1697, among France, Spain, Holland, and Germany.

France acquired the western third of the island of Santo Domingo; Spain regained all its territories won after the Peace treaty of Nimega.

1700 - The Gregorian Calendar is adopted by the countries of Germany and the Netherlands.

1730 - Santo Domingo, the Spanish colony, had 6,000 inhabitants with only the following cities: Santo Domingo, Cotui, Santiago, Azua, Banica, Monte Plata, Bayaguana, La Vega, Higuey, and Seibo.

1740 - Spanish opening of ports for foreign trade.

1752 - The Gregorian Calendar is adopted by Great Britain.

1777 - Establishment of the boundary between Haiti and the Dominican Republic by treaty.

1789 - French Revolution.

1791 - Mulattoes are granted civil and political rights by the French National Assembly, resistance by the colony results in an bloody uprising.

1793 - France goes to war with England and Spain.

1795 - Treaty of Basle, peace declared between France and Spain; Santo Domingo ceded to France.

1799 - The Audiences of Santo Domingo is moved to Puerto Principe, Cuba.

1801 - Toussaint l'Ouverture takes over city of Santo Domingo, January 27, 1801. He fully takes over the island. Mass exodus of European whites to neighboring colonies. 
1804 - After winning the last battle with France, the black generals claim independence and call the island Haiti. Jean Jacques Dessalines makes himself governor for life with dictatorial powers, orders the massacre of all the French living in Haiti. Two years later Dessalines himself was assassinated.

1805 - Dessalines continues in campaign to control the entire island, Santiago invaded, church burned down, Santo Domingo City under siege. Azua, San José de las Matas, Monte Plata, Cotui, San Francisco de Macoris, La Vega, Santiago, and Monte Cristi were reduced to ashes. Inhabitants of Moca were massacred. Ferrand stays to defeat Dessalines in Santo Domingo and force his retreat back to Haiti.

1814 - Spain takes back its dominion of Santo Domingo in the Treaty of Paris.

1822 - Haiti invades Santo Domingo and the Haitian President Boyer claims the entire island as the country of Haiti.

1824 - Americans immigrate to the island.

1844 - Dominican Republic is formed and the border disputes between Haiti and the Dominican Republic begin.

1849 - Baez elected president of the Dominican Republic.

1861 - Spain regains power of the Dominican Republic under General Pedro Santana. The Spanish take over all offices to the exclusion of native Dominicans and forced Catholicism, shutting down the Protestant churches.

1865 -Dominican Republic reclaims its independence from Spain.

1871 - Report published by a subcommittee delegated by the United Sates Congress for the possible annexation of the Dominican Republic by order of President U.S. Grant. The original treaty between the United States and the Dominican Republic for its annexation as a U.S. territory had been negotiated in 1869. Congress voted both against the treaty and annexation of the territory.

1878 - The Seminare-College St. Martial of Port-au-Prince is established.

1884 - On October 13, 1884, Greenwich is voted to be the Prime Meridian, Longitude $0^{\circ}$, by the International Meridian Conference held in Washington, D.C. It would still take decades for countries to adopt and implement a time zone based on the Prime Meridian.

1889 - The newspaper Le Nouvelliste is established in Port-au-Prince, Haiti.

1898 - The Spanish-American war began on April 1898 soon after the sinking of the USS Maine. The United States occupied Puerto Rico in July of 1898. Peace was declared with the treaty of Paris in December of 1898. The United States acquired the territories of Puerto Rico, Guam, and the Philipines and control of Cuba.

1905 - Establishment of the Astronomical and Meteorological Society of Port-au-Prince. Dr. Destouches was the first president of the society.

1914-1918 - World War I.

1915 - July 28, United States invades Haiti. The United States occupies Haiti until August 1, 1934.

1916 - May 16, U.S. occupies the Dominican Republic. U.S. occupation ends in October 1922.

1930 - The Dominican Republic overthrows their previous dictator Horacio Vasquez Lajara by civil and military coup. Rafael Leonidas Trujillo Molina was then general of the armed forces and involved in the coup. However, Trujillo established the $L a 42$, a military police used to socially and politically terrorize his opponents and as a result wins the elections held that year after the opposition steps down. Trujillo is named president of the country.

(1935 - 1945) - World War II

(1936 - 1961) - The city of Santo Domingo was nearly destroyed by a hurricane in 1931. After rebuilding the capitol, the city was renamed Ciudad Trujillo. The name of the city was not changed back to Santo Domingo until after the assassination of the dictator.

1937 - Trujillo orders the massacre of all the Haitians on the Massacre River near the border of Haiti and Dominican Republic as part of his anti-Haitian policy.

1957 - Dr. Francois Duvalier also known as "Papa Doc” is elected president of Haiti. Duvalier proclaimed himself president for life in 1964. His administration is described as despotic and contributes to the breakdown of the education system in Haiti as well as the exodus of Haitian intellectuals. He died while still in power in 1971, succeeded by his son Jean-Claude Duvalier "Baby Doc."

1961 - May 30, Trujillo assassinated. 


\section{Index of Earthquakes, by Island and by Year.}

\section{Hispaniola}

1562, December 2.

1615, September 7

1665, January ......

1673, May 9

1684 ,

1691 ,

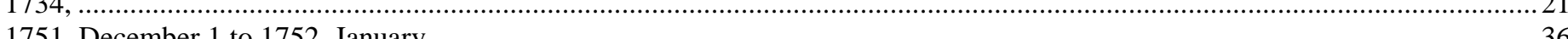

1751, May 15

1751, May 25

1751, November 1

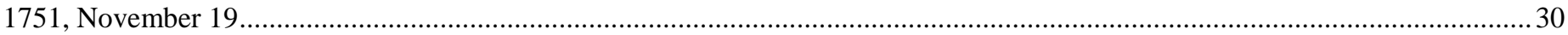

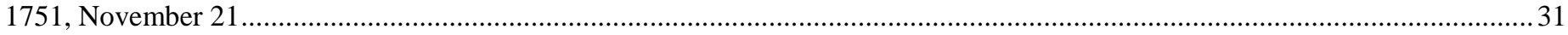

1751, November 22

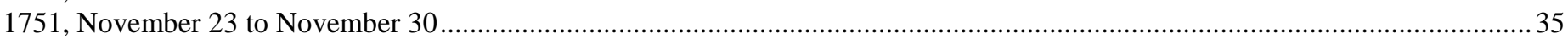

1751, October 12

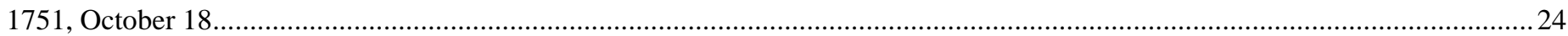

1751, October 28

1751, October 29

1751, October 8

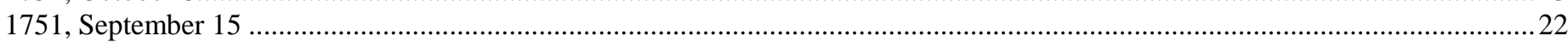

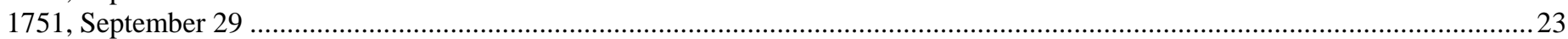

1753, 1754 and November (?) 1755

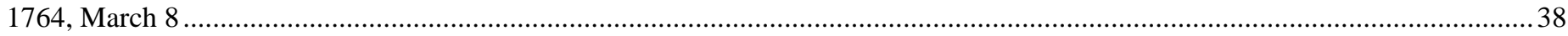

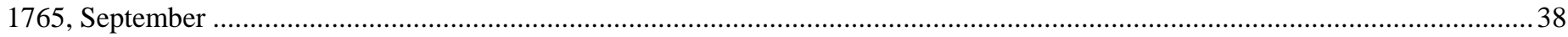

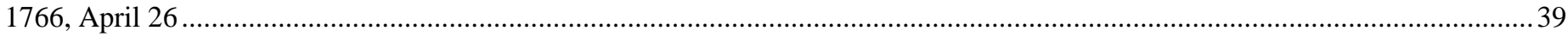

1766, January 27

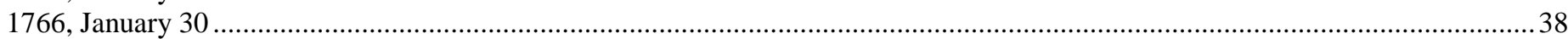

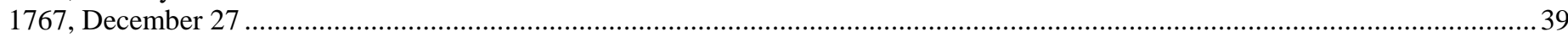

1768, January 21

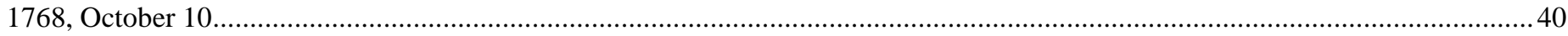

1768, October 4

1769, August 14

1770, August ...

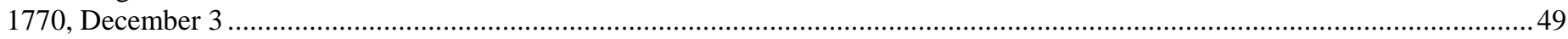

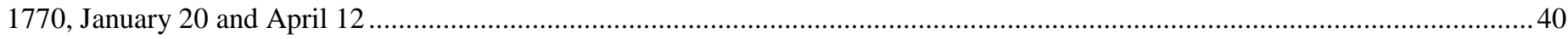

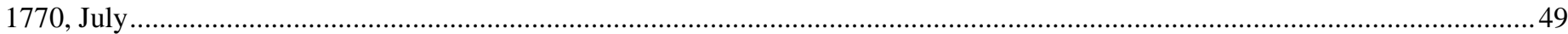

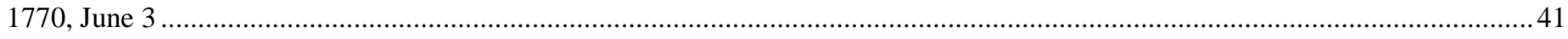

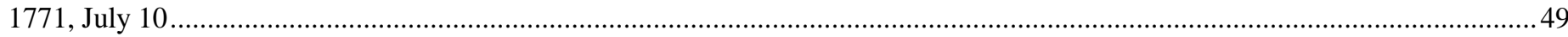

1771, October 3

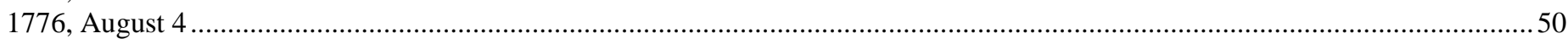

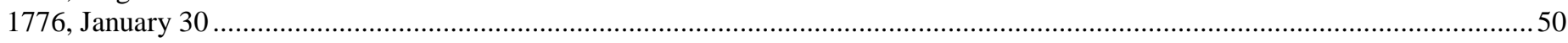

1783, February 11

1784, July 25

1784, July 29

1785, January 10

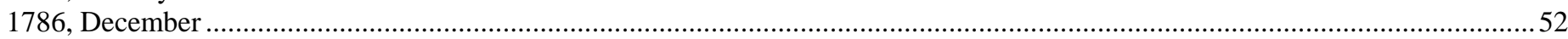

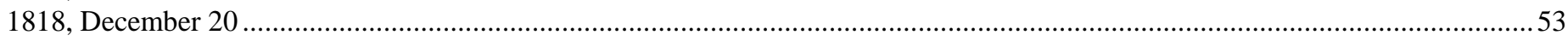

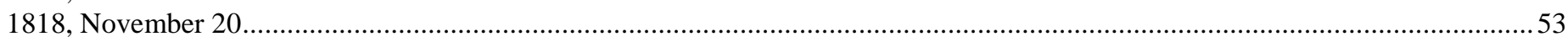

1825, November 19

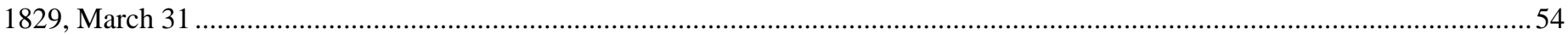

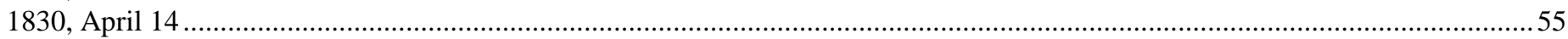

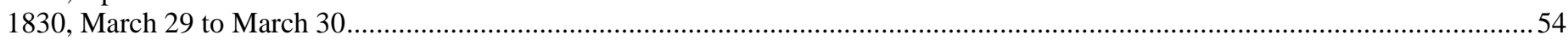

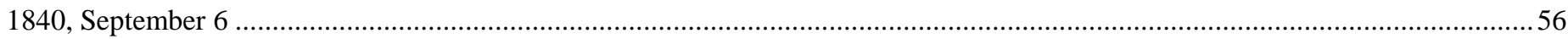

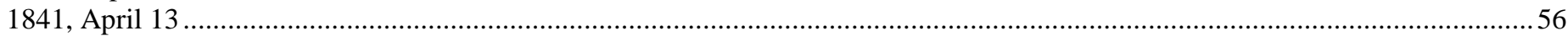

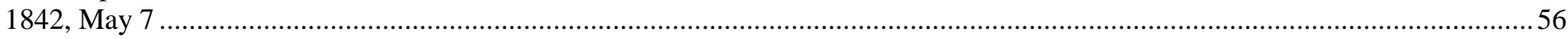


1842, May 7 to June 28

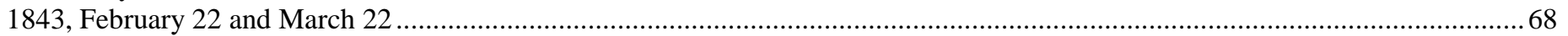

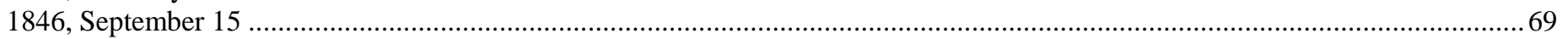

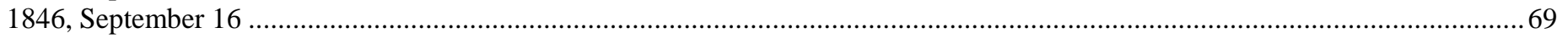

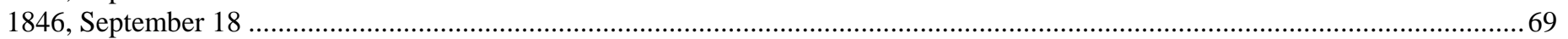

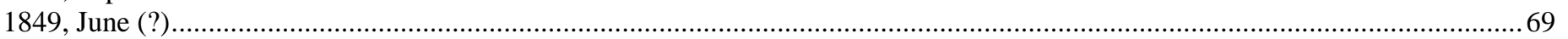

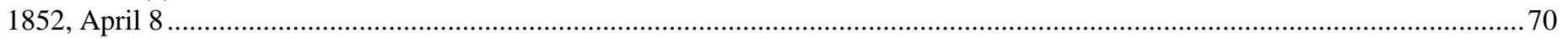

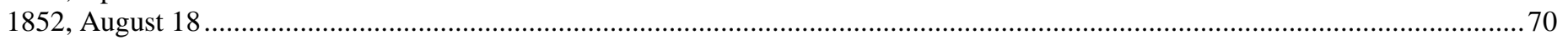

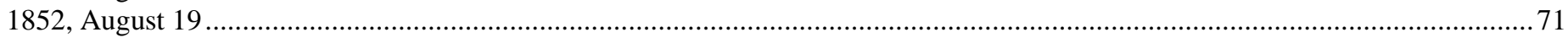

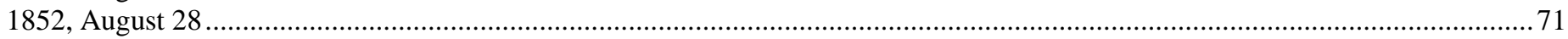

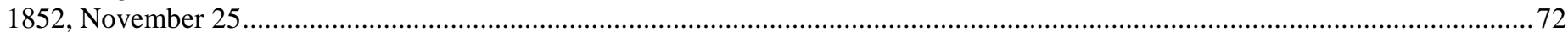

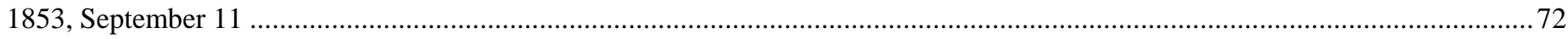

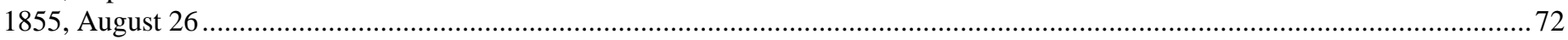

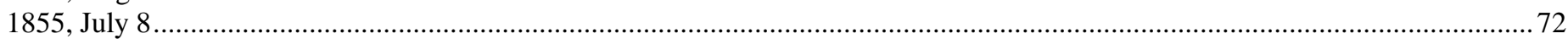

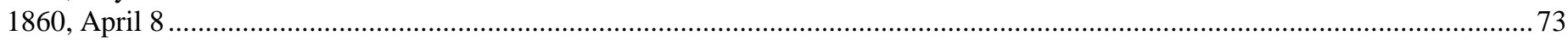

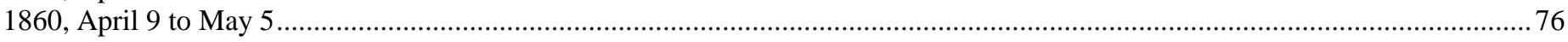

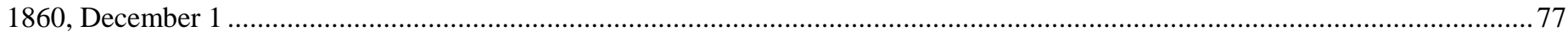

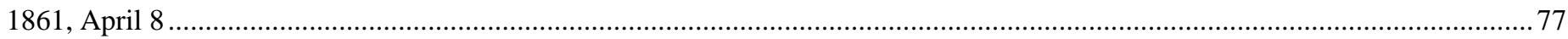

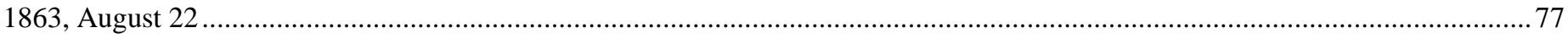

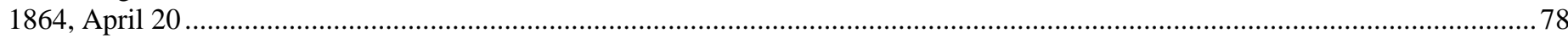

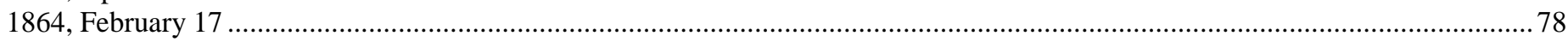

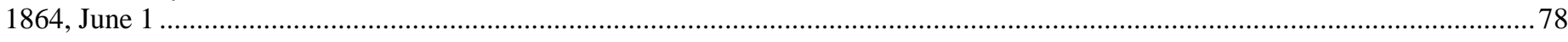

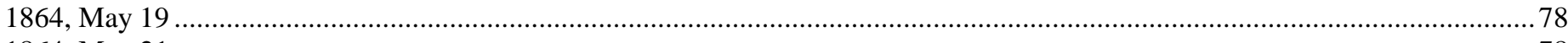

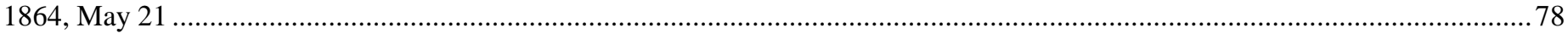

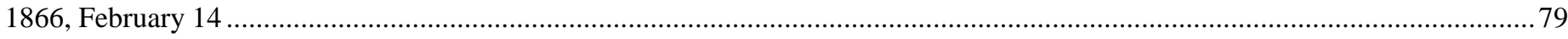

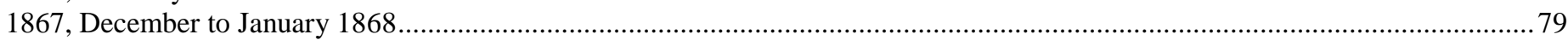

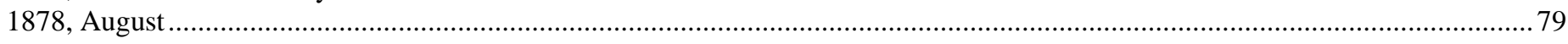

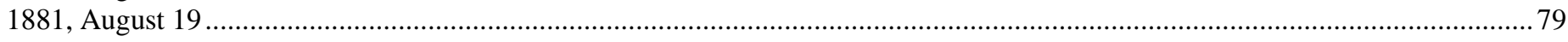

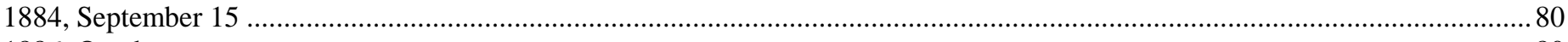

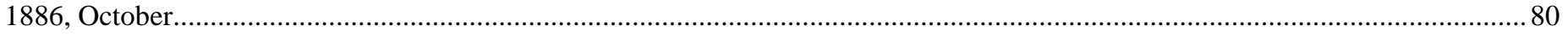

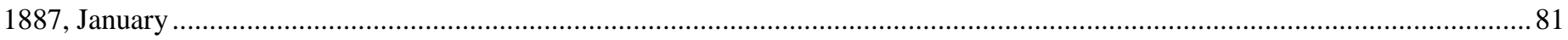

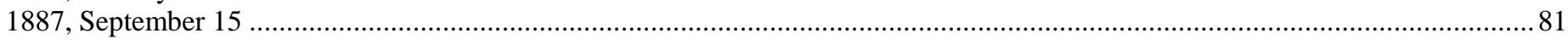

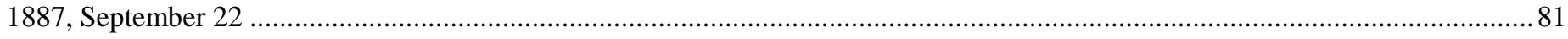

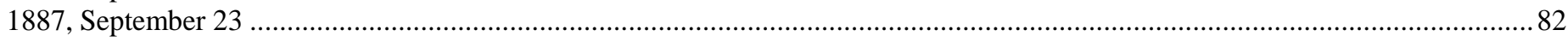

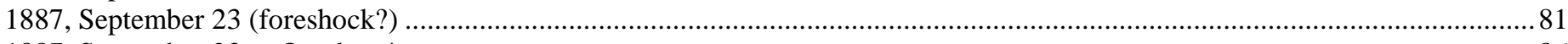

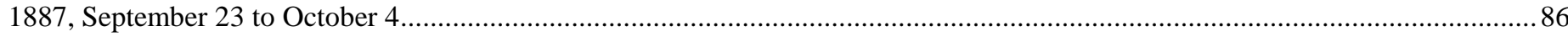

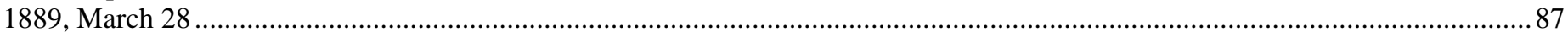

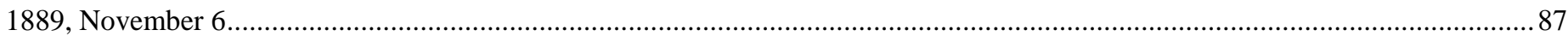

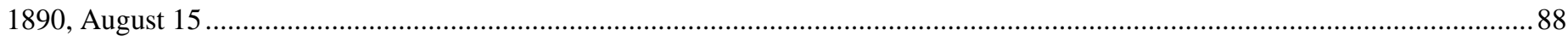

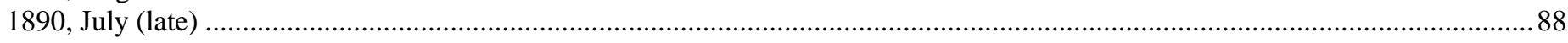

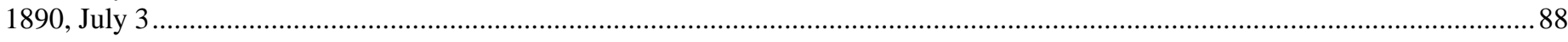

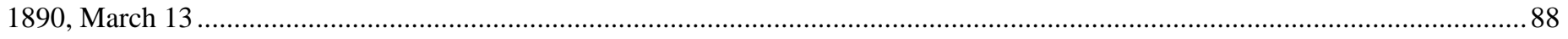

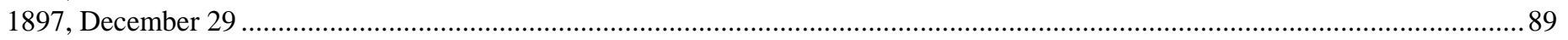

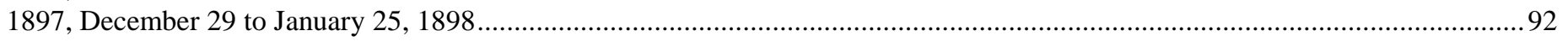

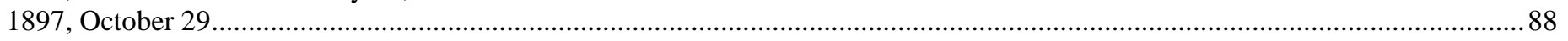

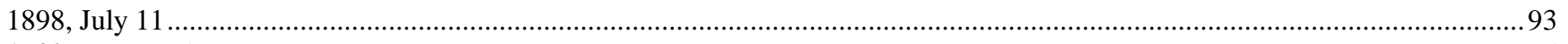

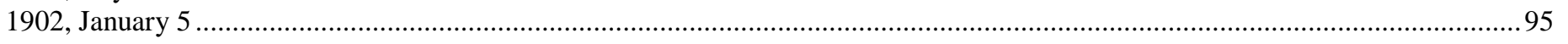

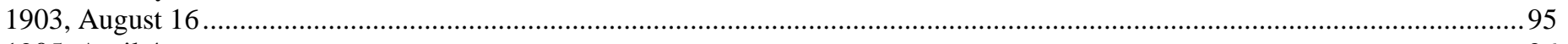

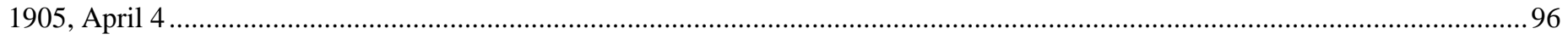

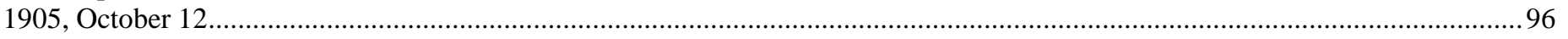

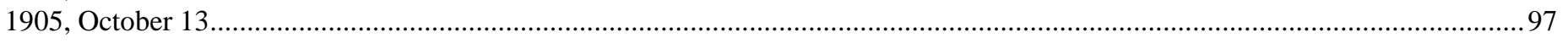

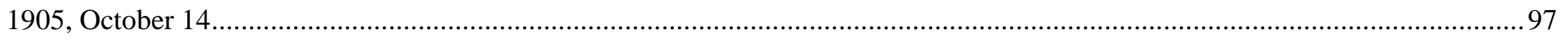

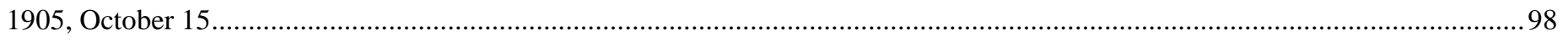

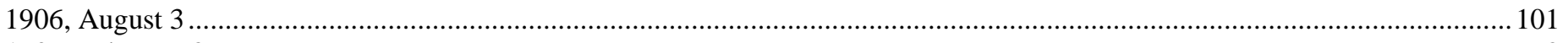

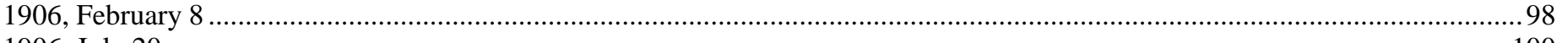

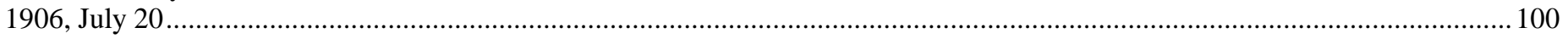

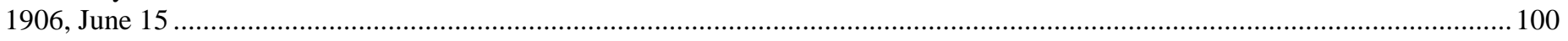

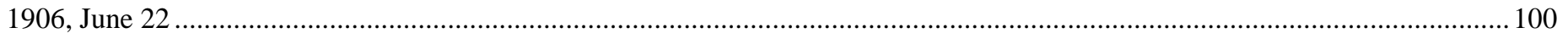

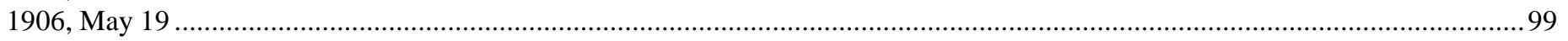

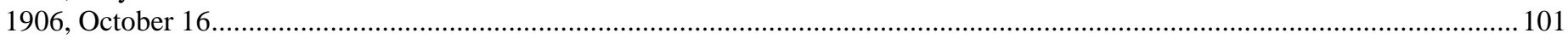

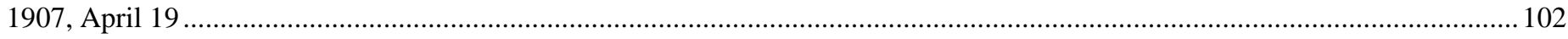

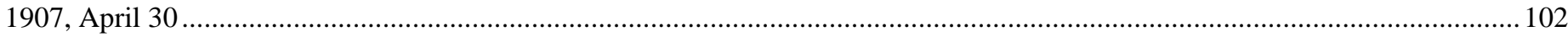

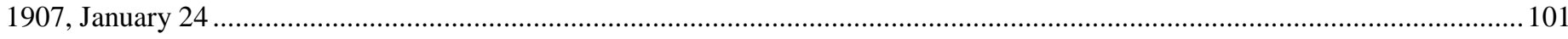

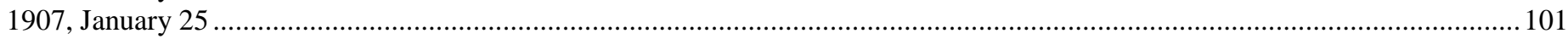




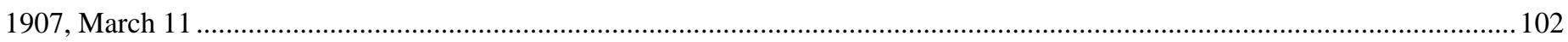

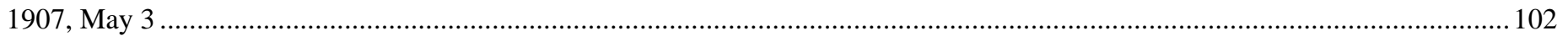

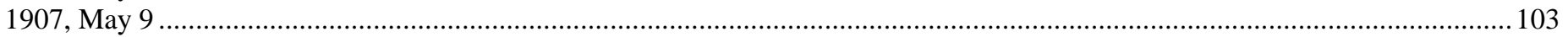

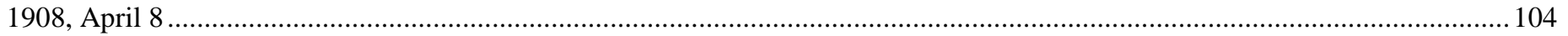

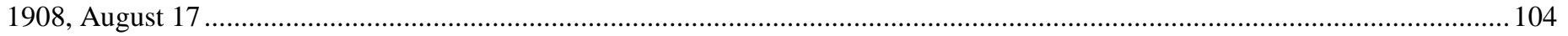

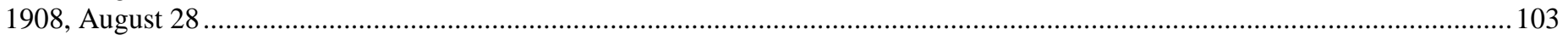

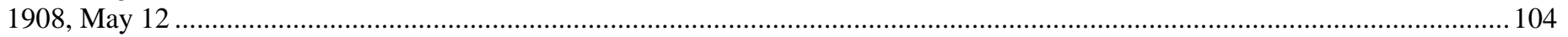

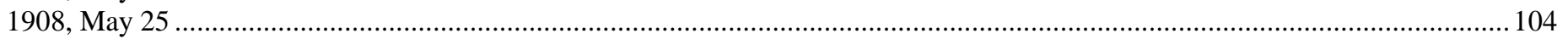

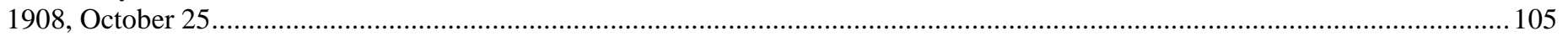

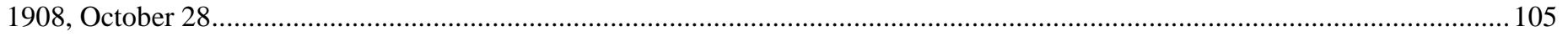

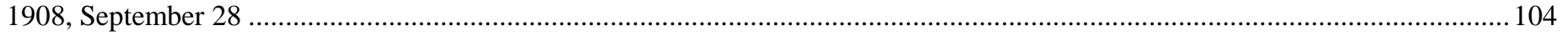

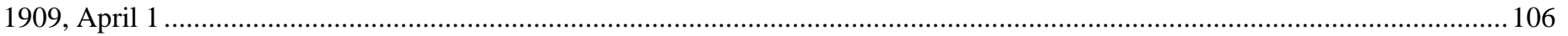

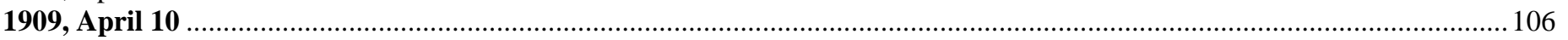

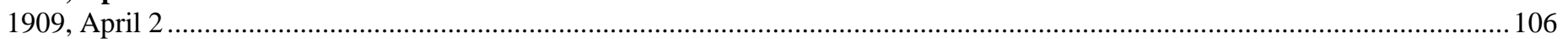

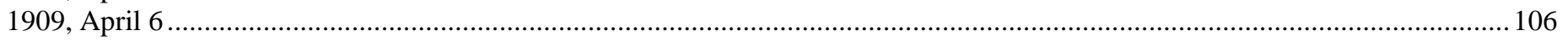

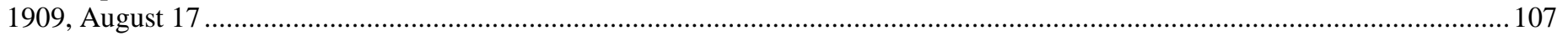

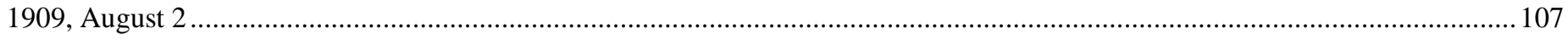

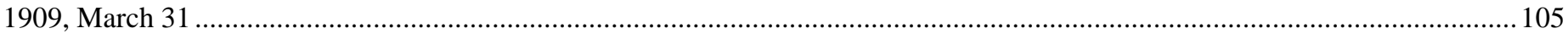

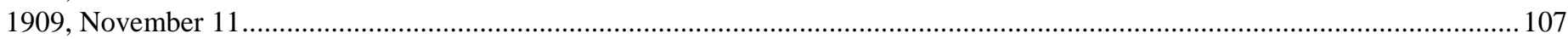

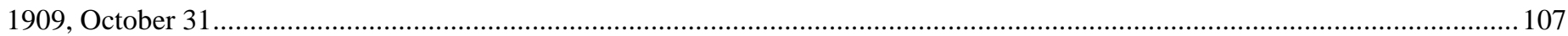

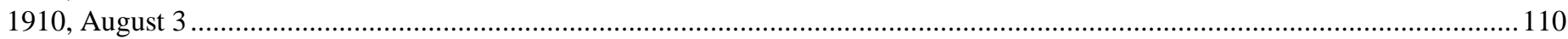

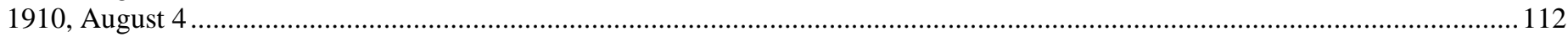

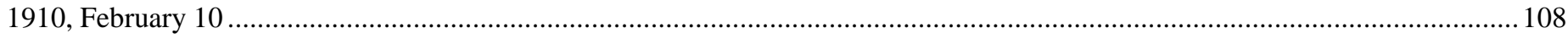

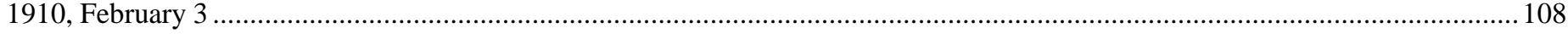

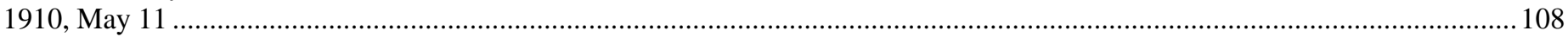

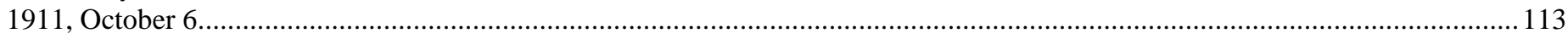

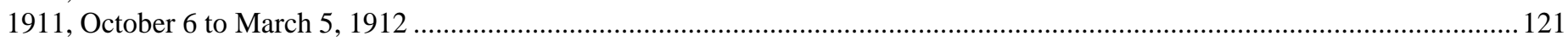

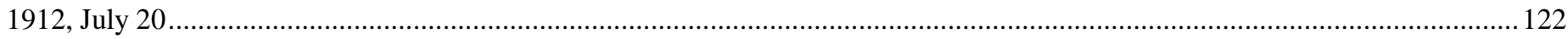

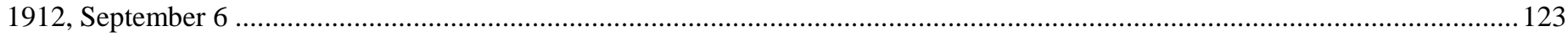

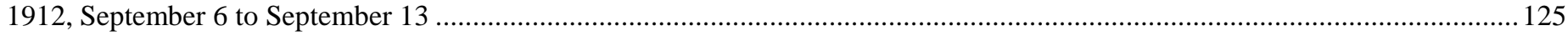

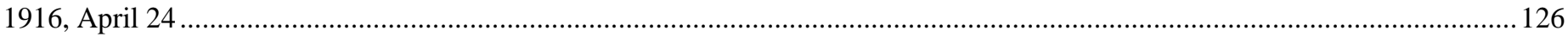

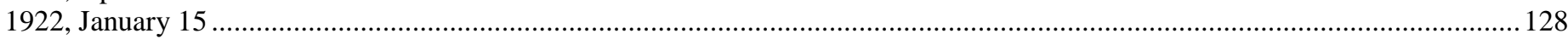

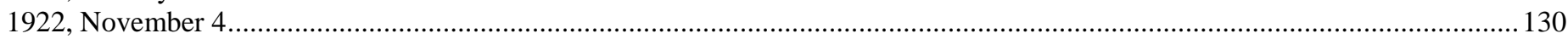

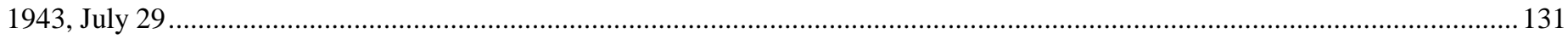

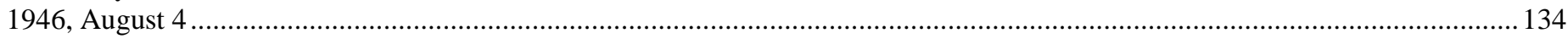

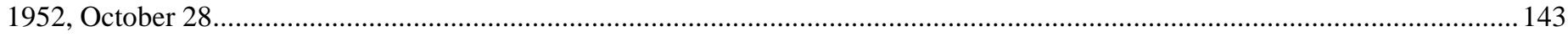

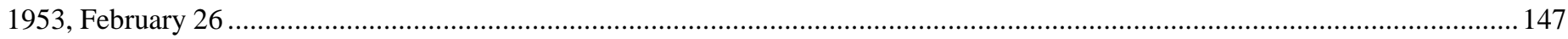

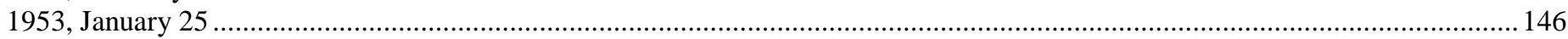

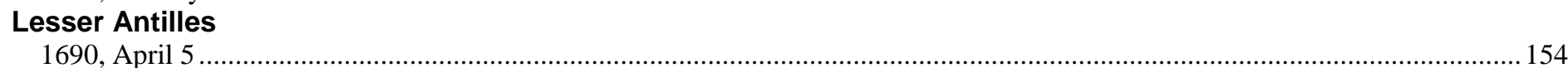

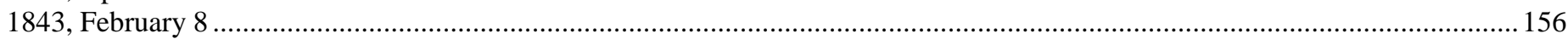

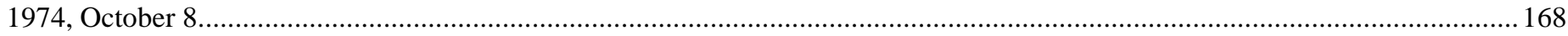

\section{Puerto Rico}

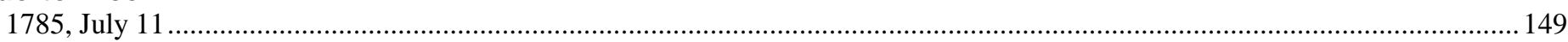

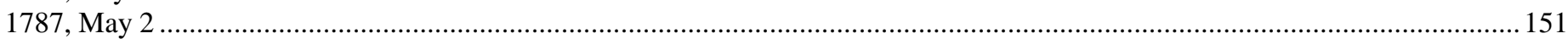




\section{References Cited}

Abe, K., 1994, Instrumental magnitudes of historical earthquakes, 1892 to 1898: Bulletin of the Seismological Society of America, v. 84, no. 2, p. 415-425.

Adams Sentinel, 1842, Earthquake at Gonaives: Adams Sentinel (Gettysburg, Pa.), June 20, 1842, p. 2., accessed August 22, 2011, at http://news.google.com/newspapers?id=TrIlAAAAIBAJ\&sjid=5PIFAAAAIBAJ\&dq=earthquake\%201842\& $\mathrm{pg}=7486 \% 2 \mathrm{C} 7555149$.

Agamennone, G., 1898, Il Terremoto di Haiti (Antille) nella mattina del 29 dicembre 1897: Bollettino della Societa Sismologica Italiana, v. 4, p. 177-191, accessed August 22, 2011, at http://hdl.handle.net/2027/mdp.39015068293110?urlappend=\%3Bseq=185.

Annual Register, 1771a, July 23d - An account was received at the General Post-Office: Annual Register, 1770 (London), v. 13, p.130-131, accessed August 22, 2011, at http://hdl.handle.net/2027/mdp.39015028180456?urlappend=\%3Bseq=172.

Annual Register, 1771b, August 7th - Paris July 30, Letters from St. Domingo confirm the melancholy account: Annual Register 1770 (London), v.13, p. 136-137, accessed August 22, 2011, at http://hdl.handle.net/2027/mdp.39015028180456?urlappend=\%3Bseq=178.

Annual Register, 1771c, October 2nd - From the London Gazette, Whitehall, October 2: Annual Register, 1770 (London), v. 13, p. 151, accessed August 22, 2011, at http://hdl.handle.net/2027/mdp.39015028180456?urlappend=\%3Bseq=193.

Annual Register, 1843, Earthquake in St. Domingo - Ten Thousand Lives Lost: Annual Register, 1842 (London), v. 84, p. 109-110, accessed August 22, 2011, at http://hdl.handle.net/2027/mdp.39015028180290?urlappend=\%3Bseq=471.

Ardouin, B., 1860, Études sur l'histoire d'Haïti; suivies de la vie du général J.-M. Borgella v. 11: Paris, Dézobry et E. Magdeleine, 362 p., accessed August 22, 2011, at http://gallica.bnf.fr/ark:/12148/bpt6k6143804w.

Associated Press, 1946, Caribbean earthquake damage heavy in wide area: Two dead: Prescott Evening Courier (Prescott, Ariz.), August 5, 1946, accessed August 22, 2011, at http://news.google.com/newspapers?id=S_IKAAAAIBAJ\&sjid=EFADAAAAIBAJ\&dq=earthquake\%20194 6\&pg=5886\%2C5276497.

Associated Press, 1946, Waves and quake damage 11 towns on Haiti Island - Ciudad Trujillo only midly hit; Call tremor "Severe”: Ellensburg Daily Record (Ellensburg, Wash.), August 5, 1946, p. 1,4, accessed August 22, 2011, at http://news.google.com/newspapers?id=Z00KAAAAIBAJ\&sjid=8UoDAAAAIBAJ\&dq=earthquake\%20194 6\&pg=5121\%2C4098652.

Bakun, W.H., and Wentworth, C.M., 1997, Estimation earthquake location and magnitude from seismic intensity data: Bulletin of the Seismological Society of America, v. 87, no. 6, p. 1502-1521.

Bakun, W.H., and Wentworth, C.M., 1999, Erratum to estimating earthquake location and magnitude from seismic intensity data: Bulletin of the Seismological Society of America, v. 89, no. 2, p. 557.

Bakun, W.H., Flores, C.H., and ten Brink, U.S., 2012, Significant earthquakes on the Enriquillo fault system, Hispaniola, 1500-2010 - Implications for seismic hazard: Bulletin of the Seismological Society of America, v. 102, n. 1, doi:10.1785/0120110077.

Barbadian, 1843a, Antigua, February 11: Barbadian, (Bridgetown, Barbados) February 15, 1843, accessed August 22, 2011, at http://www.sisfrance.net/Antilles/fiche_scan.asp?numevt=9710338\&chrono=213.

Barbadian, 1843b, Earthquake: Barbadian (Bridgetown, Barbados), February 22, 1843, accessed August 22, 2011, at http://www.sisfrance.net/Antilles/fiche_scan.asp?numevt=9710338\&chrono=209.

Barbadian, 1843c, Nevis-Extract from a letter, dated Nevis, 9th February, 1843: Barbadian (Bridgetown, Barbados), February 28, 1843, accessed August 22, 2011, at http://www.sisfrance.net/Antilles/fiche_scan.asp?numevt=9710338\&chrono=207.

Bettembourg, J.B., 1950, Le tremblement de terre du 4 Aout 1946: Bulletin de l'Observatoire Meteorologique du Séminaire Collège St. Martial, Port-au-Prince, Haiti, Résumé des Années 1935 à 1947, Port-au-Prince, Haiti, Imprimerie de L'État, p.137-138. 
Bettembourg, J.B., Schneider, V., and Schumacher, E., comps., 1950, Bulletin Sismologique, 1er Janvier 193831 Décembre 1948: Bulletin de L'Observatoire Meteorologique du Séminaire Collège St. Martial, Port-auPrince, Haiti, Résumé des Année 1935 a 1947, Port-au-Prince, Haiti, Imprimerie de L'État, p.117-136.

Bettembourg, J.B., Schneider, V., and Schumacher, E., comps., 1952, Pages anciennes et pages nouvelles de l'observatoire: Bulletin Annuel de l'Observatoire Météorologique du Séminaire Collège St.-Martial, Port-auPrince, Haiti, Année 1950, Port-au-Prince, Haiti, Imprimerie de L'État, p. 36-42.

Bettembourg, J.B., Schneider, V., and Schumacher, E., comps., 1955, Le tremblement de terre d'Anse-à-Veau: Bulletin Annuel de l'Observatoire Météorologique du Petit-Séminaire Collège St-Martial, Port-au-Prince, Haiti, Année 1952, Port-au-Prince, Haiti, Imprimerie de L'État, p. 59-81.

Bettembourg, J.B., Schneider, V., and Schumacher, E., comps., 1956, Bulletin Séismologique: Bulletin Annuel de l'Observatoire Météorologique du Petit-Séminaire Collège St-Martial, Port-au-Prince, Haiti, Année 1953, Port-au-Prince, Haiti, Imprimerie de L'État, p. 55-58.

Bodle, R.R., 1944, United States earthquakes, 1943, in United States Earthquakes 1941-1945: U.S. Geological Survey Open-File Report 84-941, p.119-170, accessed August 22, 2011,at http://pubs.usgs.gov/of/1984/0941/report.pdf.

Bollettino della Societa Sismologica Italianna, 1898, Terremoto di Haiti (Antille) Circa il mezzogiorno del 29 dicembre: Bollettino della Societa Sismologica Italiana, v. 4, supplement, p. 249-253, accessed August 22, 2011, at http://hdl.handle.net/2027/mdp.39015068293110?urlappend=\%3Bseq=543.

Branner, J.C., 1912, Reviews-Bulletin Semestriel de l'Observatoire Meteorologique de Séminaire-College St. Martial, Port-au-Prince, Haiti, Juillet-December, 1911: Bulletin of the Seismological Society of America, v. 2, no. 4, p. 261-262.

Campbell, J.B., 1972, Earthquake History of Puerto Rico, in Weston Geophysical Seismicity Investigation, Aguirre Nuclear Plant Site, Puerto Rico Water Resources Authority, Amendment no.11, to Preliminary Facility Description and Safety Analysis Report, Aguirre Plant no. 1: U.S. Army Environmental Command, docket no. 50-376, 104 p.

Charlevoix, P.-F.-X. de, 1731, Histoire de l'isle Espagnole ou de S. Domingue: Paris, Jacques Guérin, 2 v., accessed August 22, 2011, at http://gallica.bnf.fr/ark:/12148/bpt6k113009n for v. 1 and http://gallica.bnf.fr/ark:/12148/bpt6k113010k for v. 2.

Chuy, T., and Pino, O., 1982, Datos macrosísmico en la provincial Santiago de Cuba: Investigaciones Sismológicas en Cuba, v. 2, p. 46-136.

Coffman, J.L., and Stover, C.W., 1984, United States Earthquakes 1974: U.S. Geological Survey Open-File Report 84-974, 127 p., accessed August 22, 2011, at http://pubs.usgs.gov/of/1984/0974/report.pdf.

Cotte, P., 1807, Suite et fin du Tableu Chronologique de M. Cotte: Journal de Physique de Chimie et d'Histoire Naturelle, v. 65, p. 329-364, accessed August 22, 2011, at http://hdl.handle.net/2027/mdp.39015033702252?urlappend=\%3Bseq=343.

Daily News, 1946, Worst quake on record rocks Caribbean area: Daily News (Charlotte Amalie, Saint Thomas, VI), August 6, 1946, p.1, 4, accessed August 22, 2011, at

http://news.google.com/newspapers?id=K7BNAAAAIBAJ\&sjid=lkMDAAAAIBAJ\&pg=2968\%2C632078.

Day , 1910, Earthquake at San Domingo: Day (New London, Conn.), May 11, 1910, p. 1, accessed August 22, 2011, at http://news.google.com/newspapers?id=B_QgAAAAIBAJ\&sjid=hXQFAAAAIBAJ\&dq=earthquake\%20191 0\%20domingo\&pg=5838\%2C931476.

de Mairan, M., 1756, Observations de Physique Générale, 2: Histoire de L'Académie Royale des Sciences, Année 1752, p. 16-17, accessed August 22, 2011, at http://gallica.bnf.fr/ark:/12148/bpt6k35505.

de Utrera, F.C., 1995, Santo Domingo - dilucidaciones históricas, I - II. (1st ed. as one volume): (Santo

Domingo, Dominican Republic), Secretaría de Estado de Educación Bellas Artes y Cultos, 1191 p. (1st ed. volumes published separately in 1927 and 1929).

del Monte y Tejada, A., 1890, Historia de Santo Domingo: Santo Domingo, Dominican Republic, Imprenta de García Hermanos, 4 v.

Destouches, D. and Constantin, F., comps., 1906a, Résumés météorologiques du mois de Février 1906: Port-auPrince, Haiti, Société Astronomique et Météorologique de Port-au-Prince, 1 p., accessed August 22, 2011, at http://docs.lib.noaa.gov/rescue/cd012_pdf/002CEEC0.pdf. 
Destouches, D. and Constantin, F., comps., 1906b, Résumés météorologiques du mois de Mai 1906: Port-auPrince, Haiti, Société Astronomique et Météorologique de Port-au-Prince, 1 p., accessed August 22, 2011, at http://docs.lib.noaa.gov/rescue/cd012_pdf/002CEEC0.pdf.

Dominican, 1843a, An earthquake!!!: Dominican (Roseau, Dominica), February 8, 1843, accessed August 22, 2011,

at http://www.sisfrance.net/Antilles/fiche_scan.asp?numevt=9710338\&chrono=214.

Dominican, 1843b, Effects of the earthquake: Dominican (Roseau, Dominica), February 15, 1843, accessed

August 22, 2011, at http://www.sisfrance.net/Antilles/fiche_scan.asp?numevt=9710338\&chrono=215.

Eberhard, M.O., Baldridge, S., Marshall, J., Mooney, W., and Rix, G.J., 2010, The $\mathrm{M}_{\mathrm{w}} 7.0$ Haiti earthquake of January 12, 2010: USGS/EERI Advance Reconnaissance Team Report, v 1.1, 56 p., available only online at http://www.eqclearinghouse.org/20100112-haiti/wp-content/uploads/2010/02/USGS_EERI_HAITI_V1.1.pdf

El Constitucional, 1842a, Crónica Estranjera — Terremoto de Haití: El Constitucional (Barcelona), July 4, 1842, p.1, accessed August 22, 2011, at http://hemerotecadigital.bne.es/datos1/numeros/internet/Barcelona/Constitucional,\%20El\%20(Barcelona)/184 2/184207/18420704/18420704_00000.pdf\#search=\%22terremoto\%22\&page=1.

El Constitucional, 1842b, Crónica estranjera - El horroroso terremoto que á desolado a Haití: El Constitucional (Barcelona), July 9, 1842, p.1., accessed August 22, 2011, at http://hemerotecadigital.bne.es/datos1/numeros/internet/Barcelona/Constitucional,\%20El\%20(Barcelona)/184 2/184207/18420709/18420709_00000.pdf?\#search=\%22terremoto\%22.)

El Constitucional, 1842c, Por comunication del gobernador capitan jeneral de Puerto Rico: El Constitucional (Barcelona), August 5, 1842, p. 1, accessed August 22, 2011, at http://hemerotecadigital.bne.es/datos1/numeros/internet/Barcelona/Constitucional,\%20El\%20(Barcelona)/184 2/184208/18420805/18420805_00000.pdf\#search=\%22terremoto\%22\&page=1

El Correro Militar, 1887, Noticias varias: El Correo Militar — diario de la tarde, defensor de los intereses del ejército y de la armada (Madrid), September 26, 1887, p. 3, accessed August 22, 2011,at http://hemerotecadigital.bne.es/datos1/numeros/internet/Madrid/Correo\%20militar,\%20El/1887/188709/1887 0926/18870926_00000.pdf\#search=\%22terremoto\%22\&page=3.

El País, 1887, Utramar — Cuba: El País — diario republicano-progresista (Madrid), October 16, 1887, p. 3, accessed August 22, 2011, at http://hemerotecadigital.bne.es/datos1/numeros/internet/Madrid/Pa\%C3\%ADs,\%20El\%20(Madrid.\%201887) /1887/188710/18871016/18871016_00000.pdf\#search=\%22terremoto\%22\&page=3.

El Siglo Futuro, 1887, De Cuba: El Siglo Futuro — diario católico (Madrid), October 27, 1887, p. 3, accessed August 22, 2011,at http://hemerotecadigital.bne.es/datos1/numeros/internet/Madrid/Siglo\%20futuro,\%20El\%20(Madrid.\%20187 5)/1887/188710/18871027/18871027_03790.pdf\#search=\%22terremoto\%22\&page=3.

Engdahl, E. R., and Villaseñor, A., 2002, Global Seismicity, 1900-1999, in Lee, W.H.K., Kanamori, H.,Jennings, P.C.,and Kisslinger, C.,eds., International Handbook of Earthquake and Engineering Seismology: Academic Press, v. 81 sec. A, p. 665-690.

Evening News, 1916, Many are believed to have been lost in a Haitien quake today: The Evening News (San Jose, Calif.), April 24, 1916, p.1, accessed August 22, 2011, at http://news.google.com/newspapers?id=fdExAAAAIBAJ\&sjid=_uIFAAAAIBAJ\&dq=earthquake\%201916\% 20haiti\&pg=1485\%2C4406161.

Eyries, J.-B.-B., La Rendaudiere, P. F. L. d., and Klaproth, J.v., comps. 1830, Tremblement de terre à SaintDomingue: Nouvelles annales des voyages, de la géographie et de l'histoire, ser. 2, v. 47, no. 3, p. 125-126, accessed August 22, 2011, at http://gallica.bnf.fr/ark:/12148/bpt6k69812k.

Figueredo, D.H., and Argote-Freyre, F., 2008, A brief history of the Caribbean: New York, Facts on File, 310 p. Fréchet, J., Meghraoui, M. and Stucchi M., eds., 2008, Historical Seismology: interdisciplinary studies of past and recent earthquakes: New York, Springer, 443 p.

García, J.G., 1900, Compendio de la historia de Santo Domingo: Santo Domingo, Dominican Republic, Imprenta de García Hermanos, 3 v., accessed August 22, 2011, at http://catalog.hathitrust.org/Record/000774948 for v. 1, http://books.google.com/books?id=SwgUAAAAYAAJ for v. 2, and http://books.google.com/books?id=YVAeAAAAMAAJ for v. 3. 
Gay-Lussac, J.L., and Arago, F., eds., 1818, Extrait des séances de l'Académie royal des Sciences: Annales de Chimie et de Physique, ser. 2, v. 8, p. 414-417, accessed August 22, 2011, at

http://hdl.handle.net/2027/mdp.39015065225891?urlappend=\%3Bseq=418.

Gay-Lussac, J.L., and Arago, F., eds., 1825, Tremblements de terre en 1825: Annales de Chimie et de Physique, ser.2, v. 30, p. 412-414, accessed August 22, 2011, at

http://hdl.handle.net/2027/uc1.\$b617886?urlappend=\%3Bseq=410.

Gay-Lussac, J.L., and Arago, F., eds., 1826, Tremblements de terre: Annales de Chimie et de Physique, ser. 2, v. 33, p. 402-412, accessed August 22, 2011, at

http://hdl.handle.net/2027/mdp.39015065225834?urlappend=\%3Bseq=402.

Gay-Lussac, J.L., and Arago, F., eds., 1829, Tremblements de terre: Annales de Chimie et de Physique, ser. 2, v. 42, p. 347-351, accessed August 22, 2011, at http://hdl.handle.net/2027/mdp.39015065224282?urlappend=\%3Bseq=351.

Gentleman's Magazine, 1751a, Historical Chronicle, November 1751 - Saturday 30, The following ships were lost at Jamaia in a hurricane on Sept. 11, last: London, Gentleman's Magazine, November 1751, p. 522, accessed August 22, 2011, at http://hdl.handle.net/2027/mdp.39015009221550?urlappend=\%3Bseq=562.

Gentleman's Magazine, 1751b, Letter from on board a Ship at Kingston in Jamaica: London, Gentleman's Magazine,, December 1751, p. 569, accessed August 22, 2011, at

http://hdl.handle.net/2027/mdp.39015009221550?urlappend=\%3Bseq=613.

Gentleman's Magazine, 1752, Account of the late earthquakes in the island of Hispaniola, or St. Domingo, from the French relation: Gentleman's Magazine (London), February 1752, p. 91, accessed August 22, 2011, at http://hdl.handle.net/2027/mdp.39015009221634?urlappend=\%3Bseq=99.

Gentleman's Magazine, 1753, The island of Hispaniola, or San Domingo was terribly shook by earthquakes in 1751: Gentleman's Magazine (London), July 1753, p. 315-316, accessed August 22, 2011, at http://hdl.handle.net/2027/mdp.39015009221402?urlappend=\%3Bseq=345.

Gentleman's Magazine, 1770a, Historical Chronicle, July 1770 - Monday 23: Gentleman's Magazine (London), July 1770, p. 343, accessed August 22, 2011, at

http://hdl.handle.net/2027/mdp.39015016486659?urlappend=\%3Bseq=369.

Gentleman's Magazine, 1770b, American Affairs - Jamaica, June 3: Gentleman's Magazine (London), August 1770, p. 348, accessed August 22, 2011, at

http://hdl.handle.net/2027/mdp.39015016486659?urlappend=\%3Bseq=376.

Gentleman's Magazine, 1770c, Historical Chronicle, October 1770, Wednesday 31: Gentleman's Magazine (London), October, 1770, p. 485, accessed August 22, 2011, at http://hdl.handle.net/2027/mdp.39015016486659?urlappend=\%3Bseq=523.

Gentleman's Magazine, 1785, West India Intelligence: Gentleman's Magazine (London), September 1785, p. 740, accessed at http://hdl.handle.net/2027/mdp.39015013473890?urlappend=\%3Bseq=268.

Gourbeyre, A., 1843, Lettre de M. Le Gouverneur de la Guadeloupe: La Presse (Paris), March 11, 1843, p.1, accessed August 22, 2011, at http://gallica.bnf.fr/ark:/12148/bpt6k429155p/f1.

Guidoboni, E., and Ebel, J.E., 2009 Earthquakes and tsunamis in the Past-a guide to techniques in historical seismology: New York, Cambridge University Press, 590 p.

Hall, M., 1922, Earthquakes in Jamaica, from 1688 to 1919: Kingston, Jamaica, Jamaica Meteorological Service, Government printing office, 58 p. with map.

Hazard, S., 1873, Santo Domingo, Past and present; with a glance at Hayti: New York, Harper \& Brothers Publishers, 511 p., accessed August 22, 2011, at http://www.archive.org/details/cu31924084294945.

Heinl Jr., R.D. and Heinl, N.G., 1978, Writen in Blood-the story of the Haitian People 1492-1971: Boston, Houghton Mifflin Company, 785 p.

Helmsley, Capt.W.M., 1843, Royal Mail Steam Packet Dee, Barbadoes, February 13th 1843: Barbadian (Bridgetown, Barbados), February 15, 1843, accessed August 22, 2011, at http://www.sisfrance.net/Antilles/fiche_scan.asp?numevt=9710338\&chrono=213.

Hippeau, C., 1864, Nouvelles de Paris et de Versailles_-Anneé 1770: Le gouvernement de Normandie au XVIIe et au XVIIIe siècle, Documents inédits tirés des archives du Chateau d'Harcourt, (Caen, France), p. 65-66, accessed August 22, 2011, at http://books.google.com/books?id=UdYDAAAAYAAJ.

Humphreys, W.J., 1917, Section V, Seismology: Monthly Weather Review, v. 44, no. 4, p. 218-229, accessed August 22, 2011, at 
http://books.google.com/books?id=wThOAAAAYAAJ\&dq=editions\%3ALCCN74648196\&pg=PA218\#v=on epage\&q\&f=false.

Journal des Débats Politiques et Littéraires, 1842, Le tremblement de terre qui vient de désoler Haïti: Journal des Débats Politiques et Littéraires (Paris), June 29, 1842, p. 2, accessed August 22, 2011, at http://gallica.bnf.fr/ark:/12148/bpt6k445883h/f2.

L'Ami de la Religion, 1842a, Extérieur-Tremblement de Terre d'Haiti: L'Ami de la Religion, journal ecclesiastique, politique et litteraire (Paris), June 28, 1842, p. 607-608, accessed August 22, 2011, at http://gallica.bnf.fr/ark:/12148/bpt6k357132/f610.

L'Ami de la Religion, 1842b, Extérieur-Tremblement de terre à Haïti: L'Ami de la Religion, journal ecclesiastique, politique et litteraire (Paris), July 7, 1842, p. 45, accessed August 22, 2011, at http://gallica.bnf.fr/ark:/12148/bpt6k35714d/f49.

La Presse, 1842, Etranger-Amérique: La Presse (Paris), July 4, 1842, p. 3, accessed August 22, 2011, at http://gallica.bnf.fr/ark:/12148/bpt6k428899g/f3.

La Presse, 1849, Nouvelles de l'Etranger-Il n'y a aucune nouvelle politique de Santo Domingo: La Presse (Paris), July 18, 1849, p. 3, accessed August 22, 2011, at http://gallica.bnf.fr/ark:/12148/bpt6k431425m/f3.

Le Constitutionnel, 1829, Exterieur-Haiti: Le Constitutionnel, journal du commerce, politique et littéraire (Paris), June 1, 1929, p. 1, accessed August 22, 2011, at http://gallica.bnf.fr/ark:/12148/bpt6k653090b/f1.

Le Cosmos, 1898, Correspondance: Tremblement de Terre a Saint-Domingue (Antilles): Le Cosmos, revue des sciences et de leurs applications (Paris), v. 38, p. 420-421, accessed August 22, 2011, at http://books.google.com/books?id=TzYoAAAAYAAJ\&pg=PA420\#v=onepage\&q\&f=false.

Le Gaulois, 1887, Province et Etranger-Madrid: Le Gaulois (Paris), September 27, 1887, p. 3, accessed August 22, 2011, at http://gallica.bnf.fr/ark:/12148/bpt6k526267g/f3.

Le Matin, 1911, P. C. S.: Le Matin (Port-au-Prince, Haiti), October 7, 1911, p. 2, accessed August 22, 2011, at http://www.dloc.com/UF00081213/01339/2j.

Le Nouvelliste, 1903, Tremblement de Terre: Le Nouvelliste, (Port au Prince, Haiti), August 17, 1903, p. 2, accessed August 22, 2011, at http://www.dloc.com/UF00000081/12898/2j.

Le Nouvelliste, 1905a, Tremblement de terre: Le Nouvelliste (Port-au-Prince, Haiti), October 14, 1905, p. 2, accessed August 22, 2011, at http://dloc.com/UF00000081/13573/2j.

Le Nouvelliste, 1905b, Tremblements de terre: Le Nouvelliste (Port-au-Prince, Haiti), October 17, 1905, p. 2-3, accessed August 22, 201, at http://dloc.com/UF00000081/13574/2j .

Le Nouvelliste, 1911, Echo de Hinche: Le Nouvelliste (Port-au-Prince, Haiti), October 11, 1911, p. 2., accessed August 22, 2011, at http://www.dloc.com/UF00000081/15448/2j.

Le Nouvelliste, 1943, La Terre Tremble: Le Nouvelliste (Port-au-Prince, Haiti), July 29, 1943, p, 1, accessed August 22, 2011, at http://www.dloc.com/UF00000081/18823.

Le Nouvelliste, 1953a, Hier encore, la terre a tremblé à l'Anse-à-Veau: Le Nouvelliste (Port-au-Prince, Haiti), February 27, 1953, p. 1,,accessed August 22, 2011, at http://www.dloc.com/UF00000081/08139.

Le Nouvelliste, 1953b, Hier Encore, La terre a tremblé a l'Anse-a-Veau, deux morts, deux maisons effondrées et plusieurs autres endommagées: Le Nouvelliste. Port-au-Prince, Haiti, January 26,1953, p. 1, accessed August 22, 2011, at http://www.dloc.com/UF00000081/08111.

Long, E., 1774, Chapter VII, Section V: Earthquakes: The history of Jamaica or, General survey of the ancient and modern state of the island - with reflections on its situation settlements, inhabitants, climate, products, commerce, laws, and government: London, T. Lowndes, v. 3, p. 617-619, accessed August 22, 2011, at http://hdl.handle.net/2027/njp.32101064256090?urlappend=\%3Bseq=39.

Lyell, C. 1875, Principles of Geology, 12th ed.: London, Murray, 1307 p.

Lynch, J.J., and Bodle, R.R., 1948, The Dominican earthquakes of August 1946: Bulletin of the Seismological Society of America, v. 38, no. 1, p. 1-17.

Lynch, L.L., and Shepherd, J.B., 1995, An earthquake catalogue for the Caribbean, Part II, the macroseismic listing for the instrumental period 1900-1991: Melbourne, Fla., Caribbean and Latin American Seismic Hazard Project Workshop, May 1995, 47 p.

Mallet, R., and Mallet, J.W., 1858, The earthquake catalogue of the British association, with the discussion, curves, and maps, etc: London, Taylor and Francis, 674 p., accessed August 22, 2011, at http://hdl.handle.net/2027/uc1.b4182739. 
Maret, M., 1783, Memoire, sur le tremblement de terre arrive le 6 Juillet 1783: Nouveaux Memoires de

l'Academie de Dijon, pour la partie des sciences et arts, v. 1783, sem. 2, p. 27-52, accessed August 22, 2011, at http://gallica.bnf.fr/ark:/12148/bpt6k213613s/f34.

McCann, W., Feldman, L., and MaCann, M., 2011, Catalog of felt earthquakes for Puerto Rico and neighboring islands 1493-1899 with additional information for some 20th century earthquakes: Revista Geofísica, v. 62,

p. 141-293.

Meriam, E., 1853, Frequency of earthquakes: New York Times (New York), June 11, 1852, p. XX, accessed August 22, 2011, at http://www.nytimes.com/ref/membercenter/nytarchive.html.

Miami Daily News, 1943, Quake reported near Puerto Rico: The Miami Daily News (Miami), July 29, 1943, p. 1, accessed August 22, 2011, at

http://news.google.com/newspapers?id=bgktAAAAIBAJ\&sjid=udcFAAAAIBAJ\&pg=4462\%2C5308212.

Milne, J., 1912, A catalogue of destructive earthquakes, A.D. 7 to A.D. 1899: London, Offices of the Association, British Association for Advancement of Science, 92 p., accessed August 22, 2011, at http://www.archive.org/details/catalogueofdestr00britrich.

Miura, L., 1946, Quake flattens 2 island towns, Latins flee to woods when disaster strikes: Miami Daily News (Miami), August 6, 1946, p.1, 10, accessed August 22, 2011, at http://news.google.com/newspapers?id=h_0tAAAAIBAJ\&sjid=7NUFAAAAIBAJ\&dq=earthquake\%201946 \&pg=3085\%2C1706344.

Montadon, F., 1962, Les Megaseismes en Amerique: Revue pour l'Etude des Calamites, Bulletin de la Union International Secours, v. 38, p. 57-97.

Moreau de Jonnès, A., 1822, Histoire physique des Antilles françaises; Savoir_-la Martinique et les îles de la Guadeloupe: Paris, Imprimerie de Migneret, 560 p., accessed August 22, 2011, at

http://gallica.bnf.fr/ark:/12148/bpt6k5784213f.

Moreau de St.-Méry, L.-É., 1796, Description topographique et politique de la partie Espagnole de l'isle SaintDomingue: Philadelphia, Moreau de St.-Méry, L.-É., , 2 volumes,, 307 and 300 p., accessed August 22, 2011, at http://gallica.bnf.fr/ark:/12148/bpt6k111191g for v. 1 and at http://gallica.bnf.fr/ark:/12148/bpt6k111192v for v. 2.

Moreau de St.-Méry, L.-É., 1798, Description topographique, physique, civile, politique et historique de la Partie Française de l'isle Saint-Domingue: Philadelphia, Moreau de St.-Méry, L.-É., 2 volumes, 788 and 856 p., accessed August 22, 2011, at http://gallica.bnf.fr/ark:/12148/bpt6k111179t for v. 1 and at http://gallica.bnf.fr/ark:/12148/bpt6k111180r for v. 2.

New York Times, 1852, Earthquake at Cape Haytien-The Emperor Soulouque: New York Times (New York), April 30, 1852, accessed August 22, 2011, at http://www.nytimes.com/ref/membercenter/nytarchive.html.

New York Times, 1860a, New-Jersey-From St. Domingo-Earthquakes alarms and damage to property: New York Times (New York), May 2, 1860, accessed August 22, 2011, at http://www.nytimes.com/ref/membercenter/nytarchive.html.

New York Times, 1860b, Kingston,(Jamaica.) Friday, April 20, 1860—Hayti: New York Times (New York), May 24, 1860, accessed August 22, 2011, at http://www.nytimes.com/ref/membercenter/nytarchive.html. New York Times, 1887a, Earthquakes in Cuba: New York Times (New York), September 24, 1887, accessed August 22, 2011, at http://www.nytimes.com/ref/membercenter/nytarchive.html.

New York Times, 1887b, Shaken by an earthquake: New York Times (New York) October 11, 1887, accessed August 22, 2011, at http://www.nytimes.com/ref/membercenter/nytarchive.html.

New York Times, 1897, Fire and quakings in Haiti, About 3,000 persons rendered homeless in Port au Prince An earthquake alarms the town: New York Times (New York), December 30, 1897, accessesd August 22, 2011, at http://www.nytimes.com/ref/membercenter/nytarchive.html.

New York Times, 1898a, Santo Domingo earthquakes, some details of the damage inflicted upon the island:

New York Times (New York), January 20, 1898, accessed August 22,2011, at http://www.nytimes.com/ref/membercenter/nytarchive.html.

New York Times, 1898b, Earthquake at Cape Haitien: New York Times (New York), July 12, 1898, accessed August 22, 2011, at http://www.nytimes.com/ref/membercenter/nytarchive.html.

New York Times, 1916a, Earthquake in West Indies - Shocks in Santo Domingo and Porto Rico shown in seismograph: New York Times (New York), April 25, 1916, accessed August 22, 2011, at http://www.nytimes.com/ref/membercenter/nytarchive.html. 
New York Times, 1916b, Santo Domingo, Dominican Republic, April 24: New York Times (New York), April 25, 1916, accessed August 22, 2011, at http://www.nytimes.com/ref/membercenter/nytarchive.html.

Nouel, C. 1979, Historial Eclesiástica de la Arquidiócesis de Santo Domingo: Santo Domingo, Editoria de Santo Domingo, 3 volumes.

O'Loughlin, K.F., and Lander, J.F., 2003, Caribbean Tsuamis-A 500-year history from 1498-1998: Dordrecht, Netherlands, Kluwer Academic Publishers, 263 p.

Oldmixon, J., 1741, The British Empire in America, containing the history of the discovery, settlement, progress and state of the British Colonies on the continent and islands of America, (2d ed.): London, J. Brotherton \& J. Clarke, 2 volumes, 567 and 478 p., accessed August 22, 2011, at http://www.archive.org/details/britishempireina01oldm for v. 1 and at http://www.archive.org/details/britishempireina02oldm for v. 2.

Ornes, G.E., 1958, Trujillo, Little Caesar of the Caribbean: New York, Thomas Nelson \& Sons, 358 p.

Perrey, A., 1843, Note historique sur les tremblements de terre des Antilles: Comptes rendus hebdomadaires des séances de l'Académie des Sciences, v. 16, p. 1283-1303, accessed August 22, 2011, at http://gallica.bnf.fr/ark:/12148/bpt6k29751/f1283.

Perrey, A., 1847, Sur les tremblements de Terre aux Antilles: Mémoires de l'Académie des sciences, arts et belles lettres de Dijon, Années 1845-1846, p. 325-479, accessed at http://gallica.bnf.fr/ark:/12148/bpt6k57319992/f325.

Perrey, A., 1850a, Liste des tremblements de terre ressentis en 1849, avec suppléments pour les années antérieures: Mémoires de l'Académie des sciences, arts et belles lettres de Dijon, Année 1850, p. 51-71, accessed August 22, 2011, at http://hdl.handle.net/2027/mdp.39015063520368?urlappend=\%3Bseq=211.

Perrey, A., 1850b, Note sur les tremblements de terre, ressentis en 1849: Bulletins de l'Académie Royale des Sciences, des lettres et des beaux-arts de Belgique, v. 17, pt. 1, p. 216-235, accessed August 22, 2011, at http://hdl.handle.net/2027/mdp.39015065644117?urlappend=\%3Bseq=231.

Perrey, A., 1854, Note sur les tremblements de terre en 1852, avec suppléments pour les années antérieures: Mémoires de l'Académie des Sciences, arts et belles-lettres de Dijon, Annees 1852-1853, ser. 2, v. 2, p. 79128, accessed August 22, 2011, at http://gallica.bnf.fr/ark:/12148/bpt6k4081200/f337.

Perrey, A., 1855, Note sur les tremblements de terre en 1854, avec suppléments pour les années antérieures: Bulletins de l'Académie Royale des Sciences, des lettres et des beaux-arts de Belgique, v. 22, pt. 1, p. 526572, accessed August 22, 2011, at http://hdl.handle.net/2027/mdp.39015065644158?urlappend=\%3Bseq=542. Perrey, A., 1856, Note sur les tremblements de terre, en 1855, avec suppléments pour les années antérieures: Bulletins de l'Académie Royale des Sciences, des lettres et des beaux-arts de Belgique, Année 1856, v. 23, pt. 2, p. 23-68, accessed at http://hdl.handle.net/2027/mdp.39015065644018?urlappend=\%3Bseq=29.

Perrey, A., 1857, Note sur les tremblements de terre ressentis en 1855, avec suppléments pour les années antérieures: Bulletins de l'Académie Royale des Sciences, des lettres et des beaux-arts de Belgique, ser. 2, v. 1, p. 64-109, accessed August 22, 2011, at http://hdl.handle.net/2027/mdp.39015065644166?urlappend=\%3Bseq=76.

Perrey, A., 1861, Note sur les tremblements de terre en 1858, avec suppléments pour les années antérieures: Mémoires couronnés et autres mémoires, v. 12, sec. 4, p. 1-68, at http://hdl.handle.net/2027/mdp.39015065518733?urlappend=\%3Bseq=489.

Perrey, A., 1862, Note sur les tremblements de terre en 1860, avec suppléments pour les années antérieures: Mémoires couronnés et autres mémoires, v. 14, sec.3, p. 1-74, at http://hdl.handle.net/2027/mdp.39015065518972?urlappend=\%3Bseq=837.

Perrey, A., 1865, Note sur les tremblements de terre en 1863, avec suppléments pour les années antérieures, de 1843 à 1862: Mémoires couronnés et autres mémoires, v. 17, sec. 5, p.1-213, at http://hdl.handle.net/2027/mdp.39015065518964?urlappend=\%3Bseq=281.

Perrey, A., 1866, Note sur les tremblements de terre en 1864, avec suppléments pour les années antérieures, de 1845 à 1863: Mémoires couronnés et autres mémoires, v. 18, sec. 4, p. 1-98, accessed August 22, 2011, at http://hdl.handle.net/2027/mdp.39015065518956?urlappend=\%3Bseq=321.

Perrey, A., 1870, Note sur les tremblements de terre en 1866 et 1867, avec suppléments pour les années antérieures, de 1843 à 1865: Mémoires couronnés et autres mémoires, v. 21, sec. 5, pt. 2., p. 1-223, accessed at http://hdl.handle.net/2027/mdp.39015065518923?urlappend=\%3Bseq=327. 
Perrey, A., 1872a, Note sur les tremblements de terre en 1868, avec suppléments pour les années antérieures de 1843 à 1867 (XXVI relevé annuel): Mémoires couronnés et autres mémoires, v. 22, sec.3, pt. 1, p. 1-116, accessed August 22, 2011, at http://hdl.handle.net/2027/mdp.39015065518915?urlappend=\%3Bseq=73.

Perrey, A., 1872b, Note sur les tremblements de terre en 1869, avec suppléments pour les années antérieures de 1843 à 1868: Mémoires couronnés et autres mémoires, v. 22, sec. 4, pt. 1, p. 1-116, accessed August 22, 2011, at http://hdl.handle.net/2027/mdp.39015065518915?urlappend=\%3Bseq=189.

Perrey, A., 1873, Suppléments aux notes sur les tremblements de terre ressentis de 1843 à 1868: Mémoires couronnés et autres mémoires, v. 23, pt. 6, p. 1-70, accessed August 22, 2011, at http://hdl.handle.net/2027/mdp.39015065518907?urlappend=\%3Bseq=611.

Pittsburg Press, 1916, Fear loss of life in Haiti 'quake: Pittsburg Press (Pittsburg, Pa.), April 24, 1916, p. 1, accessed August 22, 2011, at http://news.google.com/newspapers?id=pgIbAAAAIBAJ\&sjid=QUkEAAAAIBAJ\&dq=earthquake\%201916 \&pg=2632\%2C3278060.

Poey, A., 1855, A chronological table, comprising 400 cyclonic hurricanes which have occurred in the West Indies and in the North Atlantic within 362 years, from 1493 to 1855; with a bibliographical list of 450 authors, books, \&c., and periodicals, where some interesting accounts may be found, especially on the West and East Indian hurricanes: London, Journal of the Royal Geographic Society,, v. 25, p. 291-328, accessed August 22, 2011 at http://hdl.handle.net/2027/mdp.39015010945817?urlappend=\%3Bseq=453.

Poey, A., 1857, Catalogue chronologique des tremblements de terre ressentis dans les Indes-Occidentales, de 1530 à 1857: Annuaire de la Société Météorologique de France, v. 5, p. 75-127, accessed August 22, 2011, at http://hdl.handle.net/2027/nyp.33433069077679?urlappend=\%3Bseq=389.

Prescott Evening Courier, 1946, Caribbean earthquake damage heavy in wide area; two dead: Prescott Evening Courier (Prescott, Ariz.), August 5, 1946, p.1, accessed August 22, 2011, at http://news.google.com/newspapers?id=S_IKAAAAIBAJ\&sjid=EFADAAAAIBAJ\&pg=5886\%2C5276497. Public Ledger, 1842, Further particulars of the earthquake in Hayti: Public Ledger (St. John, Newfoundland), July 15, 1842), p.1-2, accessed August 22, 2011, at http://news.google.com/newspapers?id=KkwIAAAAIBAJ\&sjid=aTQDAAAAIBAJ\&dq=earthquake\%20184 2\&pg=1492\%2C1258131.

Reading Eagle, 1943, Earthquake near Puerto Rico recorded: Reading Eagle (Reading, Pa.), July 29, 1943, p. 1, accessed August 22, 2011, at http://news.google.com/newspapers?id=z6IhAAAAIBAJ\&sjid=C5gFAAAAIBAJ\&dq=earthquake\%201943 \%20puerto\%20rico\&pg=5838\%2C3371090.

Richter, C.F., 1958, Elementary seismology: San Francisco, W.H. Freeman and Co., 758 p.

Robson, G.R., 1964, An earthquake catalogue for the eastern Caribbean, 1530-1960: Bulletin of the Seismological Society of America, v. 54, no. 2, p. 785-832.

Rodriguez, F., 1842, 5 de Diciembre - Necesita esta santa iglesia parroquial (Añasco) para reparar: San Juan, Puerto Rico, Archivo General de Puerto Rico, Gobernadores Españoles, Obras Públicas, Caja 226.

Saint George Chronicle, 1843a, Earthquake: Saint George Chronicle (Grenada), February 18, 1843, accessed August 22, 2011, at http://www.sisfrance.net/Antilles/fiche_scan.asp?numevt=9710338\&chrono=193.

Saint George Chronicle, 1843b, Earthquake of the 8th instant: Saint George Chronicle (Grenada), February 25, 1843, accessed August 22, 2011 at

http://www.sisfrance.net/Antilles/fiche_scan.asp?numevt=9710338\&chrono=202.

Sainte-Claire Deville, C.J., 1848, Effets du tremblement de terre sur divers points: Voyage Geologique aux Antilles et aux Iles de Téneriffe et de Fogo: Paris, Fide et J. Baudry, p. 331-333, accessed August 22, 2011, at http://www.sisfrance.net/Antilles/fiche_scan.asp?numevt=9710338\&chrono=243.

Scherer, J., comp., 1909, Mouvements sismiques: Bulletin Semestriel de l'Observatoire Meteorologique de Séminaire-Collège St-Martial, Port-au-Prince, Haiti, Janvier-Juin 1909: Port-au-Prince, Haiti, Impremerie Nationale, p. 30-32, accessed August 22, 2011, at http://docs.lib.noaa.gov/rescue/cd013_pdf/002FEB2D.pdf. Scherer, J., comp., 1910a, Mouvements sismiques: Bulletin Semestriel de L'Observatoire Météorologique du Séminare-Collège St-Martial Port-au-Prince, Haiti, Juillet-December, 1909 : Port-au-Prince, Haiti, Imprimerie National, p. 87-88, accessed August 22, 2011, at http://docs.lib.noaa.gov/rescue/cd013_pdf/002FEB2D.pdf. Scherer, J., comp., 1910b Mouvements sismiques: Bulletin Semestriel de l'Observatoire Météorologique du Séminare-Collège St-Martial, Port-au-Prince, Haiti, Janvier-Juin 1910: Port-au-Prince, Haiti, Impremeri 
National, p. 51-54, accessed August 22, 2011, at

http://hdl.handle.net/2027/mdp.39015086762393?urlappend=\%3Bseq=5720.

Scherer, J., 1911a, Renseignements meteorologiques Observatoire du Seminaire Collge St-Martial, Jeudi 4 Octobre 1911: Le Matin (Port-au-Prince, Haiti), October 6, 1911, p. 2, accessed August 22, 2011, at http://www.dloc.com/UF00081213/01338/2j.

Scherer, J., 1911b, Renseignements meteorologiques Observatoire du Seminaire College St-Martial, Vendredi 6 Octobre 1911: Le Matin (Port-au-Prince, Haiti), October 7, 1911, p. 2, accessed August 22, 2011, at http://www.dloc.com/UF00081213/01339/2j.

Scherer, J., comp., 1911c, Mouvements sismiques-Macrosismes observés dans la République du 1 er Mars au 10 Octobre 1911: Bulletin Semestriel de L'Observatoire Météorologique du Séminaire-Collège St-Martial, Port-au-Prince Haiti, Janvier-Juin, 1911: Port-au-Prince, Haiti, Imprimeire Nationale, p. 59, accessed August 20, 2011 at http://hdl.handle.net/2027/mdp.39015086762393?urlappend=\%3Bseq=223.

Scherer, J., 1912a, Great earthquakes in the island of Haiti: Bulletin of the Seismological Society of America, v. 2, no. 3, p. 161-180.

Scherer, J., comp., 1912b, Macrosismes: Tremblement de terre du 6 Octobre: Bulletin Semestriel de L'Observatoire Météorologique du Séminarie-Collège St-Martial, Port-au-Prince Haiti, Juillet-Decembre 1911 : Port-au-Prince, Haiti, Imprimerie Nationale, p. 148-152, accessed August 22, 2011, at http://hdl.handle.net/2027/mdp.39015086762393?urlappend=\%3Bseq=314.

Scherer, J., comp., 1912c, Mouvements sismiques: Bulletin Semestriel de L'Observatoire Météorologique du Séminaire-Collège St-Martial, Port-au-Prince, Haiti, Janvier-Juin 1912: Port-au-Prince, Haiti, Imprimeire Nationale, p. 52-55, accessed August 22, 2011, at http://hdl.handle.net/2027/mdp.39015086762393?urlappend=\%3Bseq=390.

Scherer, J., comp., 1916, Bulletin Sismologique: Bulletin Semestriel de L'Observatoire Météorologique du Séminaire-Collège St-Martial, Port-au-Prince, Haiti, Juillet-Decembre, 1915: Port-au-Prince, Haiti, Imprimerie Nationale, p. 173-175,accessed August 22, 2011, at http://hdl.handle.net/2027/mdp.39015086762245?urlappend=\%3Bseq=180.

Scherer, J., and Baltenweck, R., comps., 1914, Catalogue chronologique des tremblements de terre ressentis dans l'ile d'Haiti de 1551 à 1900: Bulletin Semestriel de l'Observatoire Météorologique du Séminaire-Collège St.-Matial, Port-au-Prince, Haiti, Juillet-Decembre 1913: Port-au-Prince, Haiti, Impremerie National, p.147151, accessed August 22, 2011, at http://hdl.handle.net/2027/mdp.39015086762252?urlappend=\%3Bseq=155. Scherer, J., and Baltenweck, R., comps., 1921, Tremblements de terre observés en Haiti de l'année 1901-1910: Bulletin Annuel de l'Observatoire Météorologique du Séminaire-Collège St.-Martial, Port-au-Prince, Haiti, Année 1920: Port-au-Prince, Haiti, Imprimerie National, p.100-104.

Scherer, J., and Baltenweck, R., comps., 1922, Bulletin sismologique: Bulletin Annuel de L'Observatoire Météorologique du Séminaire-Collège St-Martial, Port-au-Prince, Haiti, Année 1921: Port-au-Prince, Haiti, Imprimerie Nationale, p. 85-92.

Scherer, J., and Baltenweck, R., comps., 1923, Bulletin sismologique: Bulletin Annuel de L'Observatoire Météorolgique du Séminaire-Collège St-Martial, Port-au-Prince, Haiti, Année 1922: Port-au-Prince, Haiti, Imprimerie Nationale, p. 82-88.

Schoenrich, O., 1918, Santo Domingo a country with a future: New York, Macmillan Company, 418 p., accessed August 22, 2011, at http://www.archive.org/details/santodomingocoun00schoiala.

Sevilla Soler, M.R., 1980, Santo Domingo Tierra de Frontera (1750-1800): Sevilla, Spain, Publicaciones de la Escuela de Estudios Hispano-Americanos, Ph.D. dissertation, 502 p.

Shaler, N.S., 1869, Earthquakes of the American Continents: Atlantic Monthly (Boston), October 1869, p. 461469, accessed August 22, 2011, at http://hdl.handle.net/2027/uc1.32106019601993?urlappend=\%3Bseq=471.

Shepherd, J.B., and Lynch, L.L., 1992, An earthquake catalogue for the Caribbean, Part I, the pre-instrumental period 1502-1900: Latin American and Caribbean Seismic Hazard Programme, Melbourne, Florida, April 1992, p. 64.

SisFrance/Antilles, 2010, SisFrance-Antilles-Histoire et caractéristiques des séismes ressentis aux Antilles françaises et dans l'archipel des Caraïbes: Bureau de Recherches Geologiques et Minieres-

SisFrance/Antilles: Orleans, France, accessed August 22,2011, at http://www.sisfrance.net/Antilles/index.asp. Small, W.M., 1948, A short description of the general geology of the Dominican Republic, with notes on the earthquake of August 4, 1946: Bulletin of the Seismological Society of America, v. 38, no. 1, p. 19-32. 
Smith, W., 1745, A natural history of Nevis, and the rest of the English Leeward Charibee islands in America with many other observations on nature and art, particularly, an introduction to the art of deciphering, in eleven letters from the Revd. Mr. Smith, sometime Rector of St. John's at Nevis, and now Rector of St. Mary's in Bedford, to the Revd. Mr. Mason, B.D. Woodwardian Professor, and Fellow of Trinity College, in Cambridge: Cambridge (England), J. Bentham, p. 344, accessed August 22, 2011, at http://www.archive.org/details/naturalhistoryof00smit.

Southey, T., 1827, Chronological history of the West Indies: London, Longman Rees Orme Brown \& Green, 3 volumes, accessed August 22, 2011, at http://books.google.com/books?id=opE1AAAAIAAJ for v. 1, http://books.google.com/books?id=nqFKAAAAMAAJ for v. 2, and http://books.google.com/books?id=b3VKAAAAMAAJ for v. 3.

Spartanburg Herald, 1946, Caribbean rocked by quake registered throughout world—Puerto Rico is believed to be near Its center: Spartanburg Herald (Spartanburg, S.C.), August 5, 1946, p.1, 2, accessed August 22, 2011, at

http://news.google.com/newspapers?id=SWEsAAAAIBAJ\&sjid=BcsEAAAAIBAJ\&dq=earthquake\%201946 \&pg $=6016 \% 2 \mathrm{C} 3646608$.

Sykes, L.R. and Ewing, M., 1965, The seismicity of the Caribbean region: Journal of Geophysical Research, v. 70, no. 20, p. 5065-5074.

Taber, S., 1922, The Seismic Belt in the Greater Antilles: Bulletin of the Seismological Society of America, v. 12, no. 4, p. 199-219.

ten Brink, U.S., Bakun, W.H., and Flores, C.H., 2011, Historical perspective on seismic hazard to Hispaniola and the NE Caribbean: Journal of Geophysical Research, v.116, B12318, doi:10.1029/2011JB008497.

Times, 1843, Dreadful earthquake at Guadaloupe and Martinique: The Times (London), March 14, 1843, accessed August 22, 2011, at http://www.sisfrance.net/Antilles/fiche_scan.asp?numevt=9710338\&chrono=217.

Tippenhauer, L.G., 1893, Liste der erdbeben auf Haiti in die Insel Haiti: Leipzig, Germany, F.A. Brockhaus, p. 170-175.

Tomblin, J.F., and Aspinall, W.P., 1975, Reconnaissance report of the Antigua, West Indies, earthquake of October 8, 1974: Bulletin of the Seismological Society of America, v. 65, no. 6, p. 1553-1573.

Tomblin, J.M., and Robson, G.R., 1977, A catalogue of felt earthquakes for Jamaica, with references to other islands in the Greater Antilles, 1564-1971, in Ministry of Mining and Natural Resources, Special Publication: Kingston, Jamaica, Ministry of Mining and Natural Resources, v. 2, 243 p.

Ulrich, F.P., 1943, Seismological notes: Bulletin of the Seismological Society of America, v. 33, no. 4, p. 295297.

United Press, 1946a, Tidal waves rip West Indies-Quake strikes 600-mile area in Caribbean, 4 Dominican towns damaged heavily: Pittsburgh Press (Pittsburgh, Pa.), August 5, 1946, p.1, 4, accessed August 22, 2011, at

http://news.google.com/newspapers?id=s_UaAAAAIBAJ\&sjid=y0wEAAAAIBAJ\&dq=earthquake\%201946 \&pg=6550\%2C5454183.

United Press, 1946b, Quake, tidal wave sweep Caribbean-Four towns heavily damaged in temblor which rocks wide area of Caribbean area: Daily Times (Beaver and Rochester, Pa.), August 5, 1946, p. 1, 2, accessed August 22, 2011, at

http://news.google.com/newspapers?id=RFQyAAAAIBAJ\&sjid=t68FAAAAIBAJ\&dq=earthquake\%201946 \&pg=1595\%2C1703111.

United Press, 1946c, Sea boiled in quake, says ship Captain: Schenectady Gazette (Schenectady, N.Y.), August 7, 1946, p. 14, accessed August 22, 2011, at http://news.google.com/newspapers?id=K4ouAAAAIBAJ\&sjid=qIYFAAAAIBAJ\&pg=3136\%2C793944.

U. S. Commission of Inquiry to Santo Domingo, 1871, Dominican Republic-Report of the Commission of Inquiry to Santo Domingo, with the introductory message of the President, special reports made to the commission, state papers furnished by the Dominican government, and the statements of over seventy witnesses: Washington, D.C., Government Printing Office, 297 p., accessed August 22, 2011, at http://www.archive.org/details/cu31924021083344.

Vogt, J., 1991, Some glimpses at historical seismology: Tectonophysics, v. 193. p. 1-7. 
Vogt, J., 2009, A glimpse at the historical seismology of the West Indies: Annals of Geophysics, v. 47, no. 2-3, p. 465-476. 


\section{Appendix}

\section{Additional Material}

Quoted text extracted from de Utrera (1995, p. 17-18) explaining that the true date of the "1564" earthquake is actually December 2, 1562, based on evidence from contemporary sources.

"Que el terremoto que hizo que dieran por el suelo las ciudades de Santiago de los Caballeros y Concepción de la Vega acaeció el año 1564. - García pone la fecha del sábado 20 de Abril, según unos, y la de 2 de Noviembre, según otros [Gracia, 1900; insertado por los autores]. Como el 20 de Abril y el 2 de Noviembre caen siempre, en un mismo año, en día de la semana del mismo nombre, parece que hay acierto siquiera en el año comúnmente recibido por todos, aunque no ha faltado quien diga que como de esto no hay otra noticia, sino que así lo escribió Echagoian al rey, y fue coetáneo, debemos atenernos a la autoridad del mismo. Atengámonos a Echagoian, pero no por su testimonio único y personal, porque en el Archivo de indias se hallan los papeles siguientes: Carta del licenciado Herrera a Su Majestad, en su Real Consejo de Indias, sobre diversas materias y entre ellas noticias del terremoto ocurrido el día 2 de Diciembre anterior; tiene la fecha de 16 de Febrero de 1563. Otra carta del 13 de Febrero de 1563 suscrita por los licenciados Herrera y Echagoian y el doctor Cáceres a Su Majestad, en su Real Consejo de Indias, sobre el temblor de tierra sucedido el día 2 de Diciembre anterior de ocho a nueve de la noche, que ocasionó la calda de la Iglesia Catedral de la Vega. Otra carta del Cabildo eclesiástico de la Concepción a S. M. en su Real Consejo de Indias, sobre los destrozos hechos por el temblor de tierra del día 2 de Diciembre de 1562, y es carta que tiene la fecha de 6 de Octubre de 1563. Como se ve, esto no requiere corroboración; con todo, aquí se da para que sea cierto que lo que abunda no daña. En 1575 hicieron los dominicos de Puerto Plata una petición de socorro para su iglesia maltrecha, y en la información, que se hizo, habla una pregunta, la cuarta, escrita como sigue: ' IIII. Iten, si saben que después que se boluio [sic] a reedificar (el monasterio) y hauer [sic] hecho en el muchos costos, se boluio [sic] a caer el dormitorio del dicho monasterio de un temblor de tierra que ubo [sic] el año de sesenta y dos...' y los testigos llamados y rogados depusieron que ' dicho convento se cayo parte del, porque fue parte del dormitorio con el temblor de la tierra que la pregunta dize [sic] que ubo [sic] en esta ysla [sic] el año que la pregunta dize [sic], y hasta oy [sic] dia se esta caydo [sic]. ' "

Translation by C. Flores: [That the earthquake that threw to the ground the cities of Santiago de los Caballeros and Concepcion de la Vega occurred in the year 1564. - Garcia attributes the date to be either Saturday April 20 according to some or November 2 according to others. [Garcia, 1900; inserted by the authors]. Since November 2 and April 20 always fall on the same year and on the same named day of the week, there seems to be, to get right at least, the year which is commonly accepted by everyone. Even though, as is the case, there is no lack of persons saying that no other information exists and that this is how it was written by Echagoian to the king who was a contemporary and we must therefore abide by his authority similarly. Let us abide to Echagoian but not by his single and personal testimony because in the Archive of the Indies we find the following papers: Letter from the honorable Herrera to His Majesty, in the Real Council of the Indies, over various matters and among them news of an earthquake that occurred December 2 of the year before; which is dated February 16, 1563. Another letter dated February 13, 1563, signed by the Honorable Herrera, the honorable Echagoian, and by the doctor Caceres to His Majesty, in the Real Council of de Indies, about the earthquake that occurred on December 2 of the year before, between eight and nine at night, which resulted in the fall of the church cathedral in la Vega. Another letter from the ecclesiastical Council from Conception de la Vega to His Majesty, in the Real Council of de Indies, over the destruction caused by the earthquake of December 2, 1562, and this is a letter dated October 6, 1563. We see that this does not require corroboration; with everything shown here given to be true, that which is plentiful does not harm. In 1575 the Dominican friars in Puerto Plata made a petition to help their battered church and among the information that was made available was a fourth question, and was written as follows: “ IIII. Item, You do know that after it (the monastery) was again rebuilt and after having cost so much, the dormitory of the before mentioned monastery fell again from an earthquake that occurred in the year of sixty-two ***," and the named witnesses begged and testified that "part 
of the named monastery fell because it was part of the dormitory due to the earthquake that the question names that occurred on this island in the before mentioned year that the question names and up until now is still on the ground.”] 
Geographic locations used in the catalog for the Northern Caribbean.

Table 3. List of Locations

Tables are ordered from West to East and grouped by country or territory. For regions or large cities, a specific landmark is listed, and for small islands, the island center is also listed.

\begin{tabular}{llll}
\hline Longitude & Latitude & \multicolumn{1}{c}{$\begin{array}{c}\text { Jamaica } \\
\text { Cityltown name }\end{array}$} \\
\hline-77.6575 & 18.4928 & Falmouth & Jamaica \\
-76.7909 & 17.9840 & Kingston & Jamaica \\
-76.9525 & 17.9943 & Spanish Town (La Vega Cathedral) & Jamaica
\end{tabular}

\begin{tabular}{llll}
\hline Longitude & Latitude & \multicolumn{1}{c}{$\begin{array}{c}\text { Cuba } \\
\text { Cityltown name }\end{array}$} \\
\hline-74.4963 & 20.3459 & Baracoa & Cuba \\
-76.6501 & 20.3734 & Bayamo & Cuba \\
-76.4736 & 20.5584 & Cristo Cautu & Cuba \\
-75.2162 & 20.1419 & Guantanamo & Cuba \\
-76.2579 & 20.8854 & Holguin & Cuba \\
-77.1199 & 20.3457 & Manzanillo & Cuba \\
-75.8296 & 20.0209 & Santiago de Cuba & Cuba
\end{tabular}

\begin{tabular}{llll}
\hline Longitude & Latitude & \multicolumn{2}{c}{$\begin{array}{c}\text { Bahamas } \\
\text { Cityltown name }\end{array}$} \\
\hline-73.6741 & 20.9335 & Matthew Town (lighthouse) & Great Inagua \\
-71.1462 & 21.4674 & Cockburn Town & Grand Turks Island
\end{tabular}

\begin{tabular}{crll}
\hline \multicolumn{1}{l}{ Longitude } & \multicolumn{1}{c}{ Latitude } & \multicolumn{1}{c}{$\begin{array}{c}\text { Haiti } \\
\text { Cityltown name }\end{array}$} \\
\hline-75.0128 & 18.4018 & Navassa Island (island center) & \multicolumn{1}{c}{ Island name } \\
-72.3197 & 19.6803 & Acul du Nord & Navassa Island \\
-72.8673 & 18.8365 & Anse-a-Galets & Hispaniola \\
-73.3447 & 18.5028 & Anse-a-Veau & Gonave Island \\
-74.4519 & 18.4850 & Anse d'Hainault & Hispaniola \\
-73.3971 & 18.2816 & Aquin & Hispaniola \\
-72.5126 & 18.7701 & Arcahaie & Hispaniola \\
-73.4330 & 18.3786 & Asile & Hispaniola \\
-72.7558 & 18.1819 & Bainet & Hispaniola \\
-73.6387 & 18.4829 & Baraderes & Hispaniola \\
-72.8024 & 19.7799 & Bassin-Bleu & Hispaniola \\
-72.4308 & 19.8144 & Bayeux & Hispaniola \\
-72.5230 & 19.8463 & Borgne & Hispaniola \\
-73.3758 & 18.4657 & Brossard & Hispaniola \\
& & & Hispaniola
\end{tabular}




\begin{tabular}{|c|c|c|c|}
\hline-72.2006 & 19.7616 & Cap Haitien & Hispaniola \\
\hline-72.4105 & 18.5528 & Carrefour & Hispaniola \\
\hline-73.6552 & 18.2992 & Cavaillon & Hispaniola \\
\hline-72.3953 & 18.2311 & Cayes de Jacmel & Hispaniola \\
\hline-71.7894 & 19.1634 & Cerca-La-Source & Hispaniola \\
\hline-74.1657 & 18.2746 & Chardonnieres & Hispaniola \\
\hline-73.8890 & 18.5671 & Corail & Hispaniola \\
\hline-72.2272 & 18.5758 & Croix de Bouquets & Hispaniola \\
\hline-72.2808 & 18.6042 & Cul-de-Sac & Hispaniola \\
\hline-74.4222 & 18.5605 & Dame-Marie & Hispaniola \\
\hline-72.2403 & 19.5257 & Dondon & Hispaniola \\
\hline-71.8397 & 19.6668 & Fort Liberte & Hispaniola \\
\hline-72.3062 & 18.4165 & Furcy & Hispaniola \\
\hline-72.0630 & 18.5331 & Ganthier & Hispaniola \\
\hline-72.1892 & 18.4909 & Grande Riviere & Hispaniola \\
\hline-72.1695 & 19.5772 & Grande Riviere du Nord & Hispaniola \\
\hline-72.7709 & 18.4256 & Grand Goave (cemetery) & Hispaniola \\
\hline-72.6929 & 19.4458 & Gonaives & Hispaniola \\
\hline-72.5290 & 18.5379 & Gressier & Hispaniola \\
\hline-72.6836 & 19.6699 & Gros-Morne & Hispaniola \\
\hline-72.2004 & 18.8160 & Haut Saut-D’Eau & Hispaniola \\
\hline-72.0107 & 19.1453 & Hinche & Hispaniola \\
\hline-73.0366 & 18.8388 & Ile de la Gonave (island center) & Hispaniola \\
\hline-72.8043 & 20.0507 & Ile de la Tortue (island center) & Hispaniola \\
\hline-74.4673 & 18.4588 & Ile Pierre Joseph (near Anse d’Hainault) & Pierre Joseph \\
\hline-72.5345 & 18.2359 & Jacmel & Hispaniola \\
\hline-74.1145 & 18.6446 & Jeremie & Hispaniola \\
\hline-71.9362 & 18.8303 & Las Cahobas & Hispaniola \\
\hline-72.6334 & 18.5111 & Leogane & Hispaniola \\
\hline-73.7500 & 18.1945 & Les Cayes & Hispaniola \\
\hline-72.4025 & 19.7066 & Limbe & Hispaniola \\
\hline-72.1260 & 19.6688 & Limonade & Hispaniola \\
\hline-72.1395 & 19.1747 & Maissade & Hispaniola \\
\hline-72.6101 & 18.5383 & Mariani & Hispaniola \\
\hline-72.3459 & 19.5091 & Marmelade & Hispaniola \\
\hline-73.0861 & 18.4423 & Miragoane & Hispaniola \\
\hline-72.1040 & 18.8336 & Mirebalais & Hispaniola \\
\hline-73.3745 & 19.8052 & Mole-St. Nicolas & Hispaniola \\
\hline-71.6507 & 19.8474 & Monte Cristi & Hispaniola \\
\hline-72.8344 & 18.4395 & Mont Tapion & Hispaniola \\
\hline-74.2572 & 18.5613 & Moron & Hispaniola \\
\hline-71.7223 & 19.5501 & Ouanaminthe & Hispaniola \\
\hline-72.2864 & 18.5107 & Petionville & Hispaniola \\
\hline-72.8668 & 18.4315 & Petit Goave & Hispaniola \\
\hline-73.2446 & 18.4770 & Petit Riviere de Nippes & Hispaniola \\
\hline
\end{tabular}




\begin{tabular}{|c|c|c|c|}
\hline \multicolumn{4}{|c|}{ Haiti } \\
\hline Longitude & Latitude & City/town name & Island name \\
\hline-73.5079 & 18.5264 & Petit Trou de Nippes & Hispaniola \\
\hline-72.5504 & 19.6652 & Pilate & Hispaniola \\
\hline-72.6933 & 19.2464 & Plain Artibonite & Hispaniola \\
\hline-72.4685 & 19.5974 & Plaisance & Hispaniola \\
\hline-72.9872 & 19.6123 & Port-a-Piment & Hispaniola \\
\hline-72.3400 & 18.5400 & Port-au-Prince & Hispaniola \\
\hline-72.3388 & 18.5432 & Port-au-Prince (Presidential Palace) & Hispaniola \\
\hline-72.8370 & 19.9408 & Port-de-Paix & Hispaniola \\
\hline-72.4291 & 19.7512 & Port Margot & Hispaniola \\
\hline-73.9277 & 18.0938 & Port Salud & Hispaniola \\
\hline-72.1575 & 19.6973 & Quartier Morin & Hispaniola \\
\hline-72.0683 & 18.2370 & Sale-Trou (or Saltrou) & Hispaniola \\
\hline-72.2186 & 19.6047 & Sans-Souci Palace & Hispaniola \\
\hline-72.7239 & 19.9337 & St. Louis du Nord & Hispaniola \\
\hline-73.5466 & 18.2630 & St. Louis du Sud & Hispaniola \\
\hline-72.6978 & 19.1081 & St. Marc & Hispaniola \\
\hline-72.3340 & 19.3708 & St. Michel de l'Atalaye & Hispaniola \\
\hline-72.0984 & 18.3755 & St. Michel du Sud & Hispaniola \\
\hline-72.7275 & 19.5622 & Terre-Neuve & Hispaniola \\
\hline-72.0943 & 18.6519 & Thomazeau & Hispaniola \\
\hline-74.3959 & 18.3242 & Tiburon & Hispaniola \\
\hline-72.0223 & 19.6186 & Trou-du-Nord & Hispaniola \\
\hline-72.3297 & 18.5324 & Turgeau & Hispaniola \\
\hline-71.9207 & 19.4350 & Valliere & Hispaniola \\
\hline \multicolumn{4}{|c|}{ Dominican Republic } \\
\hline Longitude & Latitude & City/town name & Island name \\
\hline-70.8305 & 19.6717 & Altamira & Hispaniola \\
\hline-69.8605 & 19.1876 & Arenoso & Hispaniola \\
\hline-70.7291 & 18.4534 & Azua (modern, after 1751) & Hispaniola \\
\hline-70.8359 & 18.3504 & Azua (old, before 1751) & Hispaniola \\
\hline-70.3320 & 18.2799 & Bani & Hispaniola \\
\hline-71.7074 & 19.0793 & Banica & Hispaniola \\
\hline-71.0925 & 18.2051 & Barahona & Hispaniola \\
\hline-68.4518 & 18.7169 & Bavaro (hotel) & Hispaniola \\
\hline-69.6370 & 18.7520 & Bayaguana & Hispaniola \\
\hline-70.4116 & 18.9427 & Bonao & Hispaniola \\
\hline-69.7923 & 18.9458 & Boya & Hispaniola \\
\hline-70.1982 & 18.7060 & Buenaventura & Hispaniola \\
\hline-69.2602 & 19.3204 & Cabo Cabrón & Hispaniola \\
\hline-70.0295 & 19.2089 & Castilla & Hispaniola \\
\hline-70.5442 & 19.2937 & Concepcion de La Vega (ruins) & Hispaniola \\
\hline
\end{tabular}


Dominican Republic

Longitude Latitude City/town name

\begin{tabular}{|c|c|c|c|}
\hline-70.1531 & 19.0577 & Cotui & Hispaniola \\
\hline-71.3984 & 19.6687 & Guayubin & Hispaniola \\
\hline-69.2566 & 18.7622 & Hato Mayor (Mercedes Church) & Hispaniola \\
\hline-68.7168 & 18.6154 & Higuey & Hispaniola \\
\hline-71.7151 & 18.4211 & Laguna Icanoa & Hispaniola \\
\hline-68.9663 & 18.4238 & La Romana (church) & Hispaniola \\
\hline-70.5327 & 19.2239 & La Vega (modern, cathedral) & Hispaniola \\
\hline-71.0276 & 19.6400 & Maizal & Hispaniola \\
\hline-71.0735 & 19.5539 & Маo & Hispaniola \\
\hline-69.8255 & 19.3546 & Matancitas (Matanzas) & Hispaniola \\
\hline-70.5246 & 19.3929 & Moca & Hispaniola \\
\hline-69.7845 & 18.8103 & Monte Plata & Hispaniola \\
\hline-69.8465 & 19.3759 & Nagua & Hispaniola \\
\hline-70.8751 & 19.5625 & Naverette & Hispaniola \\
\hline-71.4178 & 18.4832 & Neyba & Hispaniola \\
\hline-70.5068 & 18.5471 & Ocoa (Maniel) & Hispaniola \\
\hline-70.1099 & 19.3929 & Pimentel & Hispaniola \\
\hline-70.6937 & 19.7971 & Puerto Plata & Hispaniola \\
\hline-69.3847 & 19.0648 & Sabana de la Mar & Hispaniola \\
\hline-70.4180 & 19.3796 & Salcedo & Hispaniola \\
\hline-69.3390 & 19.2061 & Samana & Hispaniola \\
\hline-70.1092 & 18.4135 & San Cristobal & Hispaniola \\
\hline-70.2593 & 19.2969 & San Franciso de Macoris & Hispaniola \\
\hline-71.2325 & 18.8074 & San Juan de la Maguana & Hispaniola \\
\hline-69.3112 & 18.4525 & San Pedro de Macoris (cathedral) & Hispaniola \\
\hline-69.3112 & 18.4526 & San Pedro de Macoris (cemetery) & Hispaniola \\
\hline-69.6131 & 19.2279 & Sánchez & Hispaniola \\
\hline-70.5468 & 19.2797 & Santa Cerro & Hispaniola \\
\hline-70.7075 & 19.4502 & Santiago de los Cabelleros & Hispaniola \\
\hline-69.8840 & 18.4734 & Santo Domingo (Catedral de St. Maria) & Hispaniola \\
\hline-69.8877 & 18.4722 & Santo Domingo (Colonial) & Hispaniola \\
\hline-69.8978 & 18.4744 & Santo Domingo (National Palace) & Hispaniola \\
\hline-69.8940 & 18.4754 & Santo Domingo (Iglesia San Carlos) & Hispaniola \\
\hline-69.0358 & 18.7625 & Seibo, Santa Cruz del & Hispaniola \\
\hline-69.0364 & 18.7648 & Seybo (modern) & Hispaniola \\
\hline-70.7289 & 18.5090 & Sierra Viajama & Hispaniola \\
\hline-70.7816 & 19.4521 & St. Yague & Hispaniola \\
\hline-70.6150 & 19.4865 & Tamboril & Hispaniola \\
\hline-69.9112 & 19.1823 & Villa Rivas & Hispaniola \\
\hline-70.9246 & 18.6107 & Yayas de Viajama & Hispaniola \\
\hline
\end{tabular}




\begin{tabular}{|c|c|c|c|}
\hline-67.1880 & 18.3796 & Aguada & Puerto Rico \\
\hline-67.1540 & 18.4275 & Aguadilla & Puerto Rico \\
\hline-66.2664 & 18.1391 & Aibonito & Puerto Rico \\
\hline-67.1414 & 18.2885 & Anasco & Puerto Rico \\
\hline-66.7321 & 18.4636 & Arecibo & Puerto Rico \\
\hline-66.0614 & 17.9665 & Arroyo & Puerto Rico \\
\hline-66.1616 & 18.3809 & Bayamon & Puerto Rico \\
\hline-67.1461 & 18.0871 & Cabo Rojo & Puerto Rico \\
\hline-66.0347 & 18.2344 & Caguas & Puerto Rico \\
\hline-66.1659 & 18.1127 & Cayey & Puerto Rico \\
\hline-66.1609 & 18.1757 & Cidra & Puerto Rico \\
\hline-66.3565 & 18.0807 & Coamo & Puerto Rico \\
\hline-65.2828 & 18.3207 & Culebra (island center) & Culebra \\
\hline-65.3010 & 18.3031 & Culebra & Culebra \\
\hline-65.4732 & 18.0980 & Esperanza & Vieques \\
\hline-65.6382 & 18.3361 & Fajardo & Puerto Rico \\
\hline-66.9085 & 17.9724 & Guanica & Puerto Rico \\
\hline-66.6702 & 18.1255 & Guaraguaos & Puerto Rico \\
\hline-66.1137 & 17.9832 & Guayama & Puerto Rico \\
\hline-66.7916 & 18.0194 & Guayanilla & Puerto Rico \\
\hline-66.1121 & 18.3579 & Guaynabo & Puerto Rico \\
\hline-67.0250 & 18.5017 & Isabela & Puerto Rico \\
\hline-66.5992 & 17.9868 & Hacienda Santa Cruz & Puerto Rico \\
\hline-66.4047 & 17.9664 & Hacienda Santa Isabel & Puerto Rico \\
\hline-65.8265 & 18.1502 & Humacao & Puerto Rico \\
\hline-66.5062 & 18.0537 & Juana Diaz & Puerto Rico \\
\hline-65.9213 & 18.2284 & Juncos & Puerto Rico \\
\hline-66.8777 & 18.2950 & Lares & Puerto Rico \\
\hline-65.8775 & 18.4300 & Loisa & Puerto Rico \\
\hline-66.4842 & 18.4314 & Manati & Puerto Rico \\
\hline-66.9799 & 18.1808 & Maricao & Puerto Rico \\
\hline-67.1407 & 18.2009 & Mayaguez & Puerto Rico \\
\hline-67.8923 & 18.0860 & Mona Island & Mona \\
\hline-65.7350 & 18.2119 & Naguabo & Puerto Rico \\
\hline-66.6207 & 17.9811 & Playa & Puerto Rico \\
\hline-66.6141 & 18.0115 & Ponce & Puerto Rico \\
\hline-66.0499 & 18.3994 & Rio Piedras & Puerto Rico \\
\hline-65.6120 & 18.2289 & Roosevelt Roads & Puerto Rico \\
\hline-66.2989 & 17.9774 & Salinas & Puerto Rico \\
\hline-67.0438 & 18.0819 & San German & Puerto Rico \\
\hline-66.1057 & 18.4665 & San Juan & Puerto Rico \\
\hline-66.9911 & 18.3383 & San Sebastian & Puerto Rico \\
\hline-65.4321 & 18.1524 & Santa Maria & Vieques \\
\hline-66.0720 & 18.4487 & Santurce (Sagrado Corazon Church) & Puerto Rico \\
\hline-66.2550 & 18.4425 & Toa Alta & Puerto Rico \\
\hline
\end{tabular}




\begin{tabular}{|c|c|c|c|}
\hline \multicolumn{4}{|c|}{ United States, Puerto Rico } \\
\hline Longitude & Latitude & City/town name & Island name \\
\hline-66.3876 & 18.4452 & Vega Baja & Puerto Rico \\
\hline-65.4248 & 18.1281 & Vieques (island center) & Vieques \\
\hline-65.4449 & 18.1474 & Vieques & Vieques \\
\hline \multicolumn{4}{|c|}{ United States, Virgin Islands } \\
\hline Longitude & Latitude & City/town name & Island name \\
\hline-64.7613 & 17.7377 & St. Croix (island center) & St. Croix \\
\hline-64.7798 & 17.7066 & Anguilla & St. Croix \\
\hline-64.7032 & 17.7467 & Christiansted & St. Croix \\
\hline-64.8815 & 17.7125 & Frederiksted & St. Croix \\
\hline-64.9299 & 18.3500 & St. Thomas (island center) & St. Thomas \\
\hline-64.9309 & 18.3420 & Charlotte Amalie & St. Thomas \\
\hline-64.9343 & 18.3280 & Hassel Island & St. Thomas \\
\hline-64.9269 & 18.3343 & St. Thomas Harbour & St. Thomas \\
\hline-64.9533 & 18.3195 & Water Island & St. Thomas \\
\hline-64.7533 & 18.3435 & St. John (island center) & St. John \\
\hline-64.7939 & 18.3312 & Cruz Bay & St. John \\
\hline
\end{tabular}

\begin{tabular}{crll}
\hline Longitude & Latitude & \multicolumn{1}{c}{$\begin{array}{c}\text { United Kingdom, British Virgin Islands } \\
\text { Cityltown name }\end{array}$} & \multicolumn{1}{c}{ Island name } \\
\hline-64.6166 & 18.3167 & Norman Island (island center) & Norman Island \\
-64.5274 & 18.3724 & Salt Island (island center) & Salt Island \\
-64.6344 & 18.4295 & Tortola (island center) & Tortola \\
-64.5704 & 18.4384 & Parham Town & Tortola \\
-64.6129 & 18.4247 & Road Harbour & Tortola \\
-64.6223 & 18.4290 & Road Town & Tortola \\
-64.5717 & 18.3522 & PeterIsland (island center) & Peter Island \\
-64.5089 & 18.3822 & Cooper Island (island center) & Cooper Island \\
-64.4022 & 18.4797 & Virgin Gorda (island center) & Virgin Gorda \\
-64.4341 & 18.4496 & Spanish Town & Virgin Gorda \\
-64.3211 & 18.7280 & Anegada (island center) & Anegada \\
-63.4258 & 18.5889 & Sombrero (island center) & Sombrero
\end{tabular}




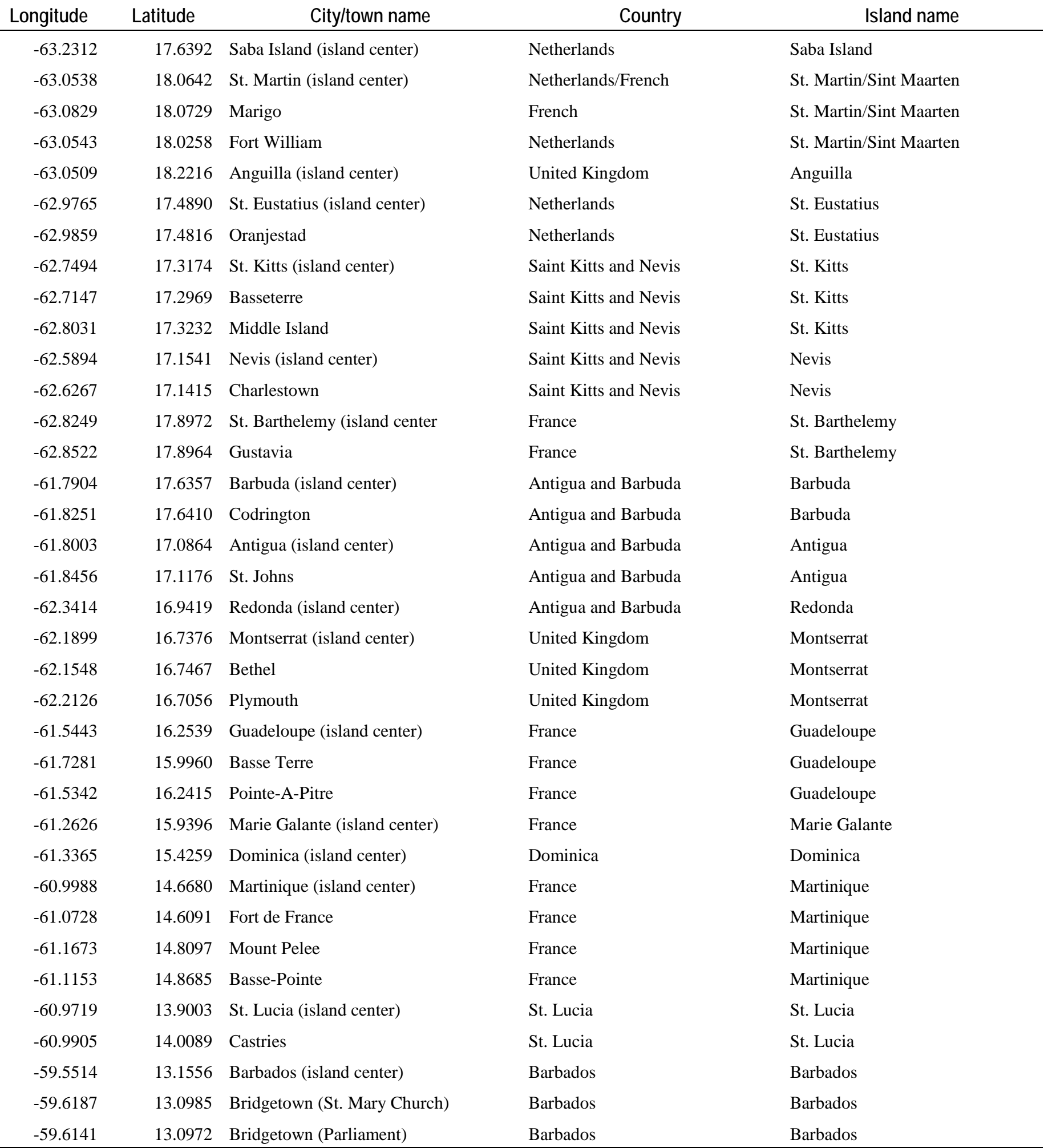


For more information concerning this report, contact

\section{Director}

U.S. Geological Survey

Woods Hole Coastal and Marine Science Center

384 Woods Hole Road

Quissett Campus

Woods Hole, MA 02543-1598

WHSC_science_director@usgs.gov

508-548-8700 or 508-457-2200

or visit our Web site at

http://woodshole.er.usgs.gov 
